\title{
LITERARY CULTURES
}

\section{AND PUBLIC OPINION IN}

\section{THE LOW COUNTRIES, 1450-1650}

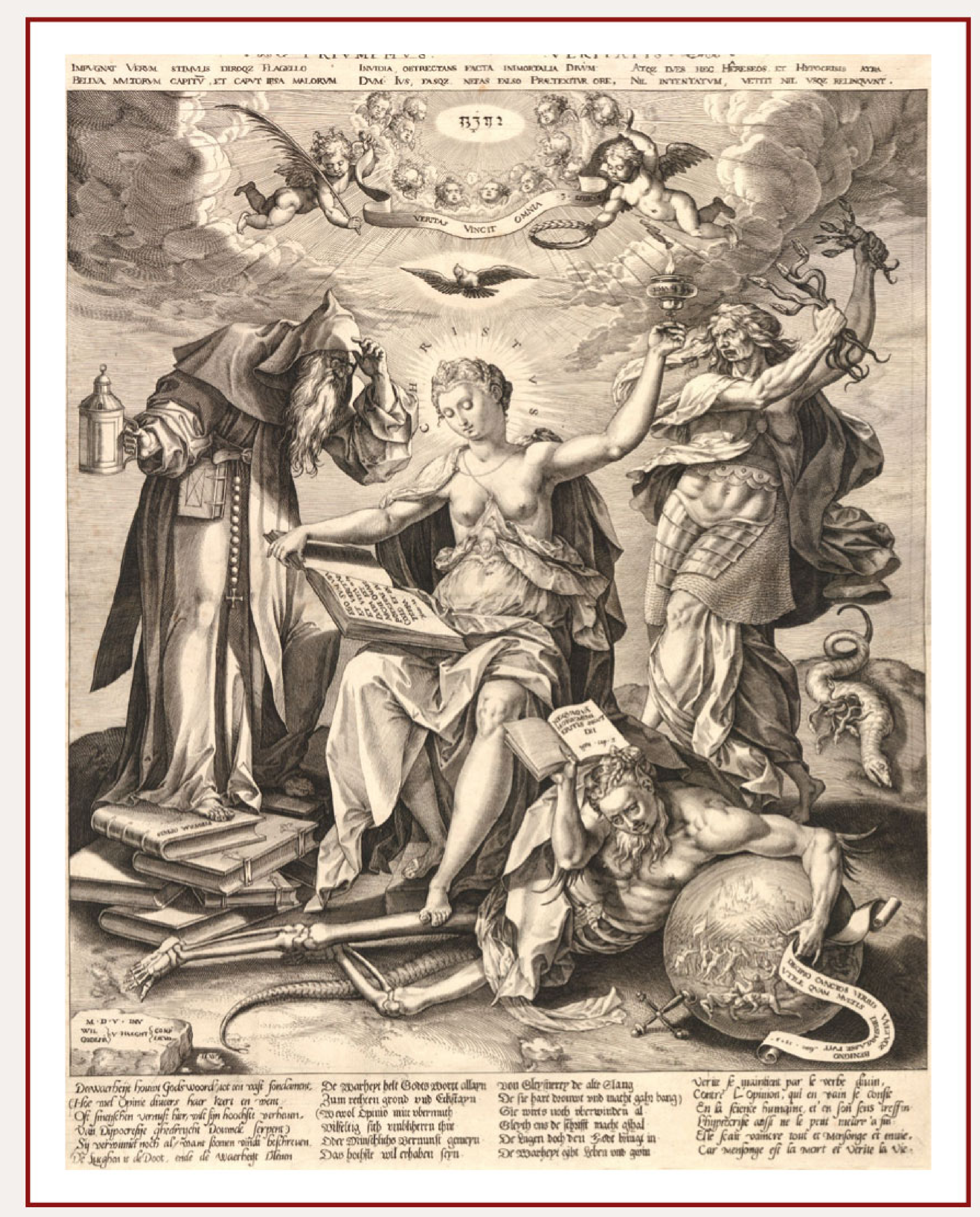

Edited by

JAN BLOEMENDAL, ARJAN VAN DIXHOORN

\& ELSA STRIETMAN

Series Editor: HAN VAN RULER

B R I L L 


\section{Literary Cultures and Public Opinion}

in the Low Countries, 1450-1650 


\title{
Brill's Studies in Intellectual History
}

General Editor

Han van Ruler, Erasmus University Rotterdam

\author{
Founded by \\ Arjo Vanderjagt
}

Editorial Board

C.S. Celenza, Johns Hopkins University, Baltimore M. Colish, Yale University

J.I. Israel, Institute for Advanced Study, Princeton M. Mugnai, Scuola Normale Superiore, Pisa

W. Otten, University of Chicago

VOLUME 197

The titles published in this series are listed at brill.nl/bsih. 


\title{
Literary Cultures and Public Opinion in the Low Countries, 1450-1650
}

\author{
Edited by \\ Jan Bloemendal \\ Arjan van Dixhoorn \\ Elsa Strietman
}

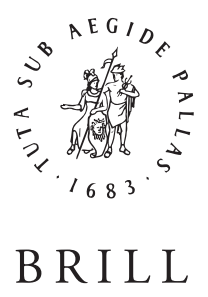

LEIDEN • BOSTON

2011 
On the cover: Triumphus Veritatis (The triumph of Truth).

Allegorical scene with Truth, a female personification, seated at centre and reading a biblical quotation while holding up a flaming lamp; flanked by Opinion as an old, bespectacled man in a hooded robe with a lamp standing on a pile of books; and Falsehood, an old hag clutching snakes and lobsters, who tramples Lies, a half-skeletal creature clutching an orb in lower right; above two putti hold a palm and wreath and a scroll lettered "Veritas vincit omnia"; after Maarten de Vos. 1579. Engraving. With kind permission of the Trustees of the British Museum.

This book is printed on acid-free paper.

ISSN $0920-8607$

ISBN 9789004206168

Copyright 2011 by Koninklijke Brill NV, Leiden, The Netherlands.

Koninklijke Brill NV incorporates the imprints Brill, Global Oriental, Hotei Publishing, IDC Publishers, Martinus Nijhoff Publishers and VSP.

All rights reserved. No part of this publication may be reproduced, translated, stored in a retrieval system, or transmitted in any form or by any means, electronic, mechanical, photocopying, recording or otherwise, without prior written permission from the publisher.

Authorization to photocopy items for internal or personal use is granted by Koninklijke Brill NV provided that the appropriate fees are paid directly to The Copyright Clearance Center, 222 Rosewood Drive, Suite 910, Danvers, MA 01923, USA.

Fees are subject to change. 


\section{CONTENTS}

List of Illustrations

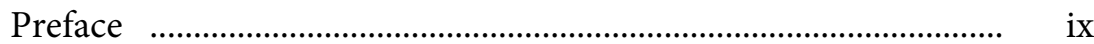

Jan Bloemendal, Arjan van Dixhoorn and Elsa Strietman

Chapter One Literary Cultures and Public Opinion in the Early Modern Low Countries

Jan Bloemendal and Arjan van Dixhoorn

Chapter Two 'You serve me well': Representations of Gossip, Newsmongering and Public Opinion in the Plays of

Cornelis Everaert

Samuel Mareel

Chapter Three 'Please Do Not Mind the Crudeness of its Weave': Literature, Gender and the Polemic Authority of Anna Bijns

Judith Keßler

Chapter Four The Morality of Hypocrisy: Gnapheus's Latin Play Hypocrisis and the Lutheran Reformation

Verena Demoed

Chapter Five Playing to the Public, Playing with Opinion: Latin and Vernacular Dutch History Drama by Heinsius and Duym

Juliette Groenland

Chapter Six Hugo Grotius in Praise of Jacobus Arminius: Arminian Readers of an Epicedium in the Dutch Republic and England

Moniek van Oosterhout

Chapter Seven Manuscript Pamphlets and Made-Up Performances: New Sources and Challenges in the Study of Public Opinion 181 Nelleke Moser 
Chapter Eight 'The Cry of the Royal Blood': Revenge Tragedy and the Stuart Cause in the Dutch Republic, 1649-1660

Helmer Helmers

Chapter Nine 'A Vile and Scandalous Ditty': Popular Song and Public Opinion in a Seventeenth-Century Dutch Village Conflict Joke Spaans

Chapter Ten Early Modern Literary Cultures and Public Opinion: An Epilogue in the Form of a Discussion Jan Bloemendal and Arjan van Dixhoorn

Bibliography

About the Authors

Index of Names and Subjects 315 


\section{LIST OF ILLUSTRATIONS}

Chapter Three

Ill. 1. Anna Bijns, MS Ghent 2166, fol. 162r. ............................... 62

Ill. 2. Anna Bijns, MS Brussels 19547, f. 37v-38r. ....................... 63

Chapter Seven

Ill. 1. RA Leiden ms. 72422 portefeuille folio, fol. 1r. ................. 187

Ill. 2. RA Leiden ms. 72422 portefeuille folio, fol. 1v. ................. 188

Ill. 3. RA Leiden ms. 72422 portefeuille folio, fol. 1r (detail). .... 191

Chapter Eight

Ill. 1. The Stage of English Miseries, Rijksmuseum, Amsterdam FM 2045a. ........................................................................ 236

Ill. 2. Artful Relation and Short Story of the Coronation of his Majesty Charles II, Atlas van Stolk 2158. 240 



\section{PREFACE}

This volume focuses on the role of literary culture in the formation of public opinion in the Low Countries between 1450 and 1650 and on the use of literature for the study of public opinion. It results from the collaboration of two research groups. Arjan van Dixhoorn was a postdoc in the Flemish-Dutch project 'Early Modern Public Opinion: Patterns, Mechanisms and Agents in the Interplay between Opinionformation and Decision-making in the Northern and Southern Low Countries 1500-1700', initiated by Hilde de Ridder-Symoens, Arjan van Dixhoorn, Bart Ramakers, Henk van Nierop and Guido Marnef and sponsored by the Flemish Organisation of Scientific Research (FWO) and the Dutch Organisation of Scientific Research (NWO). Jan Bloemendal initiated and directed the Vidi-project: 'Latin and Vernacular Cultures: Theatre and Public Opinion in the Netherlands, c. 1510-1625, funded by NWO.

The contributions to this volume as well as the use of the core concepts of literary culture and public opinion for the history of the early modern Low Countries were discussed at three meetings held in Amsterdam, Antwerp and The Hague. The cohesive element in this collection is that each contribution deals with an aspect of the intersection of forms of literary culture, be it for dissemination through oral performance, or publication via scribal or printed means. The discussions at the meetings also contributed to the cohesion and the development of our thoughts on the relationship between literature and public opinion. For pragmatic reasons, the contributions included here are confined to literature in Latin and in Dutch, although the Low Countries also had a rich literary culture in French. The latter was partly developed and sponsored by literary societies comparable to the Dutch-speaking chambers of rhetoric, such as the confraternities of the 'puys' and the compagnies joyeuses in the French-speaking Low Countries now in Belgium and France. The interplay between these three literary cultures was intense and merits further study.

The first essay serves as an introduction to the entire volume and as a programmatic 'state of the art' in relation to the study of public opinion history. It aims to lend the volume a conceptual framework. The other eight contributions are grouped in chronological order, starting 
with examples from the sixteenth century. Samuel Mareel discusses the role of representations of daily chitchat in plays by the Bruges rhetorician Cornelis Everaert (ca. 1480-1556). Judith Keßler deals with the polemical poems of the Antwerp female poet Anna Bijns (1493-1575) and the role of Franciscans and other clergymen in the making of her reputation. Verena Demoed analyzes a Latin play, Hypocrisis, written by Guilielmus Gnapheus (1493-1568) and its role in his career as a humanist and a polemicist. The focus then turns to the seventeenth century with a contribution by Juliette Groenland, who discusses the political potential of a Latin history play by the humanist Daniel Heinsius (1580-1655) and its Dutch adaptation by the rhetorician Jacob Duym (1547-before 1624). Nelleke Moser focuses on diplomatic troubles following the failure of 'the Spanish Match' (1623) and on a manuscript fragment in Dutch giving an eyewitness account of a play supposedly performed for prince Charles I (1600-1649) at the Spanish court in Madrid. Moniek van Oosterhout discusses a Latin funerary ode written by Hugo Grotius (1583-1645) for the Dutch Calvinist theologian Jacobus Arminius (1560-1609) and clarifies its publication history in the Low Countries and in Great Britain. Helmer Helmers shows how the impact on Dutch drama of the execution of Charles I on 9 February 1649 was related to the issue of a Dutch war against the English Commonwealth on behalf of the Stuarts. The closing contribution by Jo Spaans shows how a local ditty sung in the streets of a tiny village in the year 1686 was linked to national politics.

The Epilogue is first and foremost an attempt to integrate their arguments into our understanding of the role of literary culture in the process of the formation of public opinion in the Low Countries, and secondly aims to outline a model for the use of literary works in the study of public opinion in early modern Europe. It presents the contribution of this volume to the actual debate on the formation of public opinion and gives perspectives for future research.

Two of us organized the meetings and started compiling the volume and editing it. At a later stage, Elsa Strietman joined the editorship and completed our team. She cast a fresh eye on the entire volume in matters of consistency and argumentation, and corrected the English. We would like to thank Will Kelly of Minerva Professional Language Services (minerva-pls.com) who copy-edited the text.

Jan Bloemendal, Arjan van Dixhoorn and Elsa Strietman 


\title{
LITERARY CULTURES AND PUBLIC OPINION IN THE EARLY MODERN LOW COUNTRIES
}

\author{
Jan Bloemendal and Arjan van Dixhoorn
}

\section{INTRODUCTION: HOOFT AND THE POWER OF SPEECH}

In his Nederlandsche Historiën (Dutch History) of 1642, the Amsterdam man of letters Pieter Corneliszoon Hooft examined the significance of 'the art of rhyming' in the origins of the Dutch Revolt. That art, Hooft tells us, was practised in most towns and many villages of the Low Countries by 'the ablest and liveliest minds' in their chambers of rhetoric. They published poems to 'pass from hand to hand' and staged public performances of farces and serious plays in which they 'showed where everyone's duties lay'. According to Hooft, it was impossible for anyone to compete with 'de scharpheit van een gladde tong' (the sharpness of a honed tongue), which could 'persuade in one hour' and, through the passion of 'the characters', could instantly influence more people than liberally distributed 'handwritten pamphlets or printed books' could ever hope to. Rhetoricians, with their 'freedom of speech', attacked the failings of the 'papists', mocked 'blatant abuses' and fiercely condemned the persecution of heretics. ${ }^{1}$

The recital of rhymes, Hooft wrote, had therefore made a vital contribution to the growth of a critical disposition towards the clergy and towards the persecution of heretics, and as such amounted to a substantial contributing factor in the causes of the Revolt. He gave three reasons for attributing a greater influence to spoken works than to written or printed texts: the physical power of the speaker to persuade, the immediacy of the experience, and the number of people

\footnotetext{
${ }^{1}$ Hooft, Nederlandsche Historiën, pp. 36-37. See also Waterschoot, 'The rederijkerskamers en de doorbraak van de reformatie in de Zuidelijke Nederlanden', pp. 141-42. The extract (translated into modern Dutch) is also included in Hooft, Nederlandse Historiën, ed. Van Gestel, Grootes and De Jongste, pp. 52-53.
} 
who could be reached. For contemporary historians writing about the Dutch Republic, the importance of the rhetoricians for the origins of the Revolt was a truism they deployed, among other things, in the defence of the chambers and their public plays against attacks by clergymen of the Reformed Church. ${ }^{2}$

Sixteenth-century political, religious and intellectual authorities were themselves concerned about the persuasive power of songs and poems. Fearing the divisive potential of such works, they developed special censorship rules such as bans on the treatment of certain subjects, the checking of texts prior to performance, and thereafter prosecution and, where deemed necessary, sanctions. ${ }^{3}$

Hooft's belief in the efficacy of performative literature to communicate ideas is at odds with the notion still prevailing today that the printing of books was responsible for an enormous increase in the rapid and extensive dissemination of opinions, and that the Reformation would not have been possible without this revolution in communications. The latter view has been modified substantially in recent years by historians of the Reformation, giving more weight to the spoken word that received so much praise from Hooft for forming a connection between the public and the world of written and printed texts. ${ }^{4}$ Hooft believed that by 1560 the Low Countries had an organized literary life, sustained by cultured minds who criticized frankly the performance of the authorities in public, reminding both citizens and people in positions of power of their responsibilities. The rhetoricians' regional

2 Among those who quote this argument with approval are Geeraerd Brandt in his Historie der Reformatie, I, 229 and Emanuel van Meteren in his Historie der Nederlandscher ende haerder Na-buren Oorlogen ende geschiedenissen, fol. 29r-v. See also for example Waterschoot, 'De rederijkerskamers en de doorbraak van de Reformatie', pp. 151-53.

${ }^{3}$ For the ban on the printed collection of stage offerings for the competition in Ghent in 1539 see Van Bruaene, 'Printing Plays'. For a discussion of the Protestant nature of these plays see: Waite, Reformers on Stage and Ramakers, 'In utramque partem vel in plures'. For the development of the censorship policy with regard to the stage in Holland and Zeeland and the failure of a local commission of theologians established in 1551 for the censoring of plays prior to performance, see Van Dixhoorn, Lustige geesten, p. 324. It is worth adding that the authorities sometimes acted harshly but on other occasions were comparatively mild, and local governments varied in the extent to which they took notice of orders from central government.

${ }^{4}$ The relationship between the spoken, written and printed word outside the world of scholarship has been explored by, for example, Scribner, 'Oral Culture and the Diffusion of Reformation Ideas'; Fox, The Spoken Word, and idem, Oral and Literate Culture in England 1500-1700; and Pettegree, Reformation and the Culture of Persuasion. They emphasize that spoken and performed works were often written down or printed, and printed and written works often read aloud, recited and acted. 
networks are evidence that the literary life of early modern societies helped to create supra-local communities in which, as Hooft saw it, collective opinions were formed which governments had to take into account. ${ }^{5}$ Both the existence of such supra-local vehicles for creating public opinion in a world of performative literature and Hooft's interpretation of their importance seem at first sight to conflict with the view of German sociologist Jürgen Habermas that before 1700 such supra-local communities did not exist, any more than the concept of public opinion existed. ${ }^{6}$

Habermas is relevant here because the model and the criteria he used to explain the development of a modern public sphere, and the place that public opinion occupied in it, have become paradigmatic. Criticism has been brought to bear on certain aspects, and revisions have been proposed, some of which we shall examine later, but the notion that a modern public sphere could develop only with the rise of a critical national press and an informed, engaged and critical national public coming together in nationwide networks of societies, salons, coffee houses, theatres and concert halls is nevertheless broadly accepted. ${ }^{7}$ As a result, much of the research inspired by Habermas has been firmly focussed on seventeenth and eighteenth-century news and opinionshaping publications, and on meeting places frequented by cultured citizens and the forms of politicization found there. One result is that sixteenth-century developments have been unjustly downplayed, to say nothing of such developments in the Middle Ages. ${ }^{8}$

\section{Points of Departure}

In this chapter we examine the process of the formation of public opinion in the early modern Low Countries with a special focus on the insufficiently examined role of literature in forming opinions and ways

\footnotetext{
${ }^{5}$ See, for instance, Van Dixhoorn, 'Chambers of Rhetoric'.

${ }^{6}$ Habermas, The Structural Transformation of the Public Sphere; translation of idem, Strukturwandel der Öffentlichkeit.

7 For a collection of criticisms see Calhoun, Habermas and the Public Sphere: see also Mah, 'Phantasies of the Public Sphere'. For a thorough German critique: Jäger, Öffentlichkeit und Parlamentarismus.

${ }^{8}$ For the existence of supra-local publics in the Middle Ages and early modern era see for example Scribner, 'Oral culture'; Wohlfeil, 'Reformatorische Öffentlichkeit'; Hadfield, Literature, Politics and National Identity; Faulstich, Medien und Öffentlichkeiten im Mittelalter 800-1400; idem, Medien zwischen Herrschaft und Revolte; Coldiron, 'Public Sphere / Contact Zone'.
} 
of thinking. We will attempt to show that-in contrast to assumptions made by Habermas and like-minded scholars-the early modern Low Countries did in fact have the potential to develop a public opinion, and that literary works were important in this regard.

In early modern society, literary texts were of great significance to both the shaping and the public expression of ideas. Among Dutch and Flemish literary historians it is now generally accepted that literary texts helped to form opinions. ${ }^{9}$ Unfortunately, in carrying out historical research into public opinion, sociocultural and political historians in the Netherlands and Flanders tend to ignore literary works as sources. ${ }^{10}$ It seems self-evident that the importance of literary texts can be properly understood only if the texts themselves, their authors, printers and publishers are studied as part of a broader process of opinion-formation, which often takes shape in a debate. ${ }^{11}$ We will demonstrate that it should be no less natural for historians to use responses to social, political, religious and other issues which appeared in a literary form as well as other sources. Such literary sources should be used, not primarily as a way of lending historical work an attractive style and artistic treatment but as documents that, in their own right, serve as an integral part of such investigations. The fact that literary works are a most important source has everything to do with the overwhelmingly oral (or: face-to-face) character of society in the early modern period. ${ }^{12}$

${ }^{9}$ Important advocates of this view include Herman Pleij and Marijke Spies. See also Van Stipriaan, Het volle leven. A methodological reconsideration of this point by Marijke Spies can be found in Joost van den Vondel, Twee zeevaartgedichten, ed. Spies, p. viii (our thanks to Anita Boele for this reference). Spies comments that the literary author 'confirms and sustains an idea, a tendency, an attitude, even when he is unaware of it. This often implies that he also takes a specific position with respect to social developments and therefore fulfils a function in opinion-forming in relation to such developments'.

${ }_{10}$ An exception is, for instance, Rodríguez Pérez, The Dutch Revolt through Spanish Eyes. Some historical studies that focus on the related topic of identity-formation also make use of literary works, including chronicles.

${ }^{11}$ An exception in the older literature is Van Gelder's 'Satiren der zestiendeeeuwsche kleine burgerij'. A recent example of an early modernist who pays particular attention to the social role of literary texts is Frijhoff, Wegen van Evert Willemsz.

${ }_{12}$ Much relevant work has been done on early modern England-for instance in the volumes edited by Sharpe and Zwicker, Politics of Discourse and Reading, Society, and Politics in Early Modern England-but we aim to shed light on the situation in the Low Countries. 
Using literary texts as sources in research into processes of opinionformation requires a methodological and conceptual framework, in which starting points, research questions, research topics and methodologies are grounded in the relevant academic disciplines: the social sciences and historical and literary studies. In this article we aim to initiate the development of such a framework, in the belief that historical and literary-historical research into the significance of literary works in the process of opinion-formation is necessary in order to understand early modern society, and that such research increases our insight into the character of the literature of the period. We will also advocate allocating the Low Countries the place they deserve in the study of the history of publicity and the rise of public opinion as an independent force in social life. We are convinced that these regions of Europe, which were in many respects highly developed and offer a wealth of sources, ought to become important reference points in the debate.

We use a tentative definition of public opinion as a complex of beliefs about social, political, moral, religious and other public matters, one that can be found in larger or smaller segments of society and which originates and is expressed in a variety of ways. We focus on the entire process by which opinions are formed, in other words: on the formation of public opinion rather than on the individual opinions themselves. The ways in which views are shaped and expressed, whether publicly or not, are of course fundamental to this process. In early modern society those texts that we now call 'literature' were crucial to the shaping and dissemination of opinions. We will examine problems surrounding the concepts of literature and public opinion and attempt to come to a more precise working definition of both. Finally, we will delineate the starting points with which literary texts can be used to investigate the formation and functioning of public opinion in the early modern Low Countries.

\section{A PRECISE DEFINITION OF THE CONCEPT OF LITERATURE}

Defining what is meant by literature is problematic for a period in which the concept as we know it did not exist. In this article we approach issues as pragmatically as possible. We do not attempt to give an ontological definition of a universal category called literature; rather we take as our point of departure the forms and procedures that 
we now recognize as literary, even though we realize that this is no less problematic than attempting to offer a definition. ${ }^{13}$

Literature in our current sense is an anachronistic concept when applied to the early modern era, mainly because the distinction between literary and non-literary forms of expression and communication was far less clear-cut in that period, even non-existent. Many early modern authors operated in the shadow of classical authors, and in Antiquity, in the Middle Ages, and in the Renaissance period practically all written texts came under the heading of litterae ('written letters') from which our concept of 'literature' is derived. Furthermore, the concept of literature comprised not just written works but forms of oral literature such as poems and songs. In the Respublica litteraria (the international, indeed supranational Republic of Letters of the early modern period), which operated in Latin, people spoke of bonae litterae ('belles lettres'), meaning classical and patristic literature in a broad and comprehensive sense and the intellectual world that was bound up with it. This broad field of bonae litterae allowed people access to their classical heritage and the civilization of Antiquity. The term therefore came to stand for a particular cultural ideal and for learning and education in general, including a feeling for style and good taste, knowledge of history and mythology, expertise in the fields of language and letters, and a familiarity with philosophical and other intellectual movements. The Latin schools, which taught boys who were sent to them by ambitious parents, were based on this civilizing ideal plus the Latin language. Through them, as well as for example through organizations devoted to some or all seven of the liberal arts like the chambers of rhetoric, the same ideal permeated the non-Latin and non-literary worlds. ${ }^{14}$

${ }^{13}$ It has nevertheless been tried. See for example Abrams and Harpham, A Glossary of Literary Terms, pp. 152-53 under 'Literature': 'designates fictional and imaginative writings - poetry, prose fiction, and drama. In an expanded use, it designates also any other writings [...] that are especially distinguished in form, expression, and emotional power'. Korsten, Lessen in literatuur, p. 8 takes as his starting point the question 'What do people in specific sociocultural circumstances do with literature and what does literature do with them?' This evades the question of what literature 'is', or what (for example) the specific function of literature is in relation to other forms of text. See also Van Heusden, 'Omhelsd door de retorica'.

${ }_{14}$ These form one element of the studia humanitatis. See for example Grafton and Jardine, From Humanism to the Humanities, pp. 122-57 and 138-49; Kohl, 'Humanism and Education'. Classicists still employ a comparably broad definition of literature, encompassing poetry, scholarly texts in verse and in prose, history writing and 
In the early modern era writers based their approach to writing on the rules of rhetoric, or the art of speaking well. By implementing these rules, authors of literary texts attempted to formulate their thoughts eloquently. They paid heed to the rules governing invention (inventio), arrangement (dispositio) and style (elocutio) with their requirements of linguistic purity, clarity, ornamentation and aptness. ${ }^{15}$ Authors of texts we would now describe as non-literary, such as pamphlets, made use of the same rhetorical methods. ${ }^{16}$ Rhetoric aimed at convincing people, at changing their minds, so it had a persuasive function. ${ }^{17}$ In an early modern face-to-face society, in which written and printed books were still scarce, these were the means of creating convincing arguments. ${ }^{18}$ The result was a close connection between a predominantly oral and performative culture and the use of literary forms, such as the division into stanzas, repetition, rhythm, metre, melody, rhyme and hyperbole, as well as textual forms such as disputes and conversations, and allegorical representations of arguments.

In light of this, the definition of a work as 'literary' is mainly a matter of forms of literary encoding. Placards and minutes of meetings do not qualify as literature, but when the Haarlem rhetorician Louris Janszoon, in his play Het Cooren (The Grain), quotes an anti-monopoly placard almost word for word, he thereby moves the placard into the literary category. ${ }^{19}$ The reverse was also possible. In 1404-1405, when Jan Mattijssen, the city secretary of Den Briel, set down the common law in a hefty work, he punctuated his juridical text with a variety of short, anecdotal stories taken from the Bible, classical Antiquity, and contemporary history, intended as a means of illustrating the regulations. ${ }^{20}$ There is a reciprocal intertwining here between literary and

philosophical works. For the role of the chambers of rhetoric in the shaping of the cultural ideal of the liberal arts in the vernacular see Van Dixhoorn, Lustige geesten, pp. 214-54.

${ }^{15}$ For example Leeman and Braet, Klassieke retorica, pp. 98-117.

${ }^{16}$ See for example Vrieler, Het poëtisch accent. In the section 'Literatuur in pamfletten: de stand van onderzoek' (pp. 18-20) he completely passes over the question of what literature is. He focuses on poetry (which he defines as 'texts that rhyme').

${ }^{17}$ Leeman and Braet, Klassieke retorica, pp. 54-55.

${ }^{18}$ See Meijer Drees, 'Pamfletten: Een inleiding', pp. 11-18 on influencing readers. She too looks at literary aspects of the pamphlet but rightly decides not to define the pamphlet as distinct from literature.

${ }_{19}$ See Hummelen and Dibbets (eds.), Het Cooren (1565) van Lauris Jansz.

20 Taken from Pleij, Het gevleugelde woord, p. 22. 
explicitly non-literary forms, as was very common until at least the seventeenth century. ${ }^{21}$

The effect of texts that to us are clearly literary was comparable to that of pamphlets, for example, which arrived on the scene in the Low Countries after $1566 .{ }^{22}$ Although they are rightly seen as utilitarian or occasional works, their authors often made use of literary methods and forms. ${ }^{23}$ They sometimes did so quite extensively, even incorporating whole tragedies. Joachim Oudaen's Haegsche broeder-moord, of dolle blydschap (Fratricide in The Hague, or Mad Merriment, 1712), for example, can be regarded as a pamphlet. ${ }^{24}$ The stage play Auriacus, sive Libertas defensa (Orange, or the Defence of Liberty, 1599) by Caspar Ens was in many instances bound together with the essay in pamphlet form De iure belli Belgici adversus Philippum regem Hispaniarum (The Laws of War of the Dutch Against Philip, King of Spain), probably because the printer spotted a commercial opportunity. In so doing, to some extent he turned the play into a pamphlet, and it may have been read as such by contemporaries. Both the stage play and the essay convey arguments aimed at justifying the war against Philip II of Spain and, after he died in 1598, against Philip III. ${ }^{25}$

The concept of genre denotes a form of literary encoding that ostensibly differentiates literature quite clearly from other forms of communication. ${ }^{26}$ Early modern authors presented their literary products

21 'Poems', for example, appear in several of Verhoeven's newsletters: Simoni, 'Poems, Pictures and the Press'.

${ }^{22}$ For the breakthrough of the pamphlet in the Netherlands, see Harline, Pamphlets, Printing and Political Culture in the Early Dutch Republic.

${ }^{23}$ Vrieler, Het poëtisch accent; Clazina Dingemanse, Rap van tong, scherp van pen; De Kruif, Meijer Drees, and Salman, Het lange leven van het pamflet. See also Maczkiewitz, Der niederländsche Aufstand gegen Spanien (1568-1609), pp. 196-98 on the numbers of printed works that appeared in the Low Countries.

${ }^{24}$ See Joachim Oudaen, Haegsche Broeder-Moord, of Dolle Blydschap. Treurspel, p. 45. Compare also Duits, Van Bartholomeusnacht tot Bataafse opstand, p. 22.

25 Ens, Princeps Auriacus, sive Libertas defensa (1599), ed. by Bloemendal and Steenbeek. De iure belli Belgici adversus Philippum regem Hispaniarum (...) Seorsum accessit Princeps Auraicus sive Libertas Defensa. De iure belli Belgici, was published in Delft by Bruyn Schinckel, while Princeps Auriacus was published in The Hague by Albrecht Heyndricksz. Apparently Schinckel saw in the stage play a recommendation for the pamphlet. By 'pamphlet form', we mean a non-pretentious form of printed matter primarily focused on current issues, but it is clear that the concept of a pamphlet is no easier to define than the concept of literature. See for example Marijke Meijer Drees, 'Pamfletten: Een inleiding' and especially Verkruijsse, " "Gedruckt in seghwaer, op de pars der lijdtsaemheyt”. Boekwetenschap en pamfletliteratuur', esp. pp. 32-33.

26 See also, on theatre, Bloemendal, 'Receptions and Impact'. 
as morality plays, rhetorical farces, tragedies, comedies, tragicomedies or farces, or as epics, ballades or didactic poems, and in so doing they made conscious use of genre labels. According to modern concepts of genre, such texts, like songs and verses, fall under the heading of literature, but the example of the pamphlet demonstrates that no clear boundaries can be drawn around this criterion to distinguish such a text from other kinds of text. And what about dialogues, which in the form of the Colloquia by Erasmus undoubtedly belong to literature but are, as mere schuitepraatjes (gossip) and other genres that mimic everyday chitchat, always placed in the same category as 'trivia' and pamphlets? ${ }^{27}$ Still, in many texts with little in the way of literary allure, the literary form and encoding are clearly present. So it would be right to speak of a continuum from high-brow literary to low-brow literary categories and forms, in which high-brow stands for a clear ambition, a considerable level of knowledge, a high degree of intertextuality, and a sophisticated mastery of literary forms, while low-brow indicates the opposite.

In early modern times, works that used literary forms were present everywhere in daily life: at work, during protests, in times of political and social unrest, at festivals, in the tavern and in company, in church and in Bible groups, and they ranged from very informal to very formal, from low-brow to high-brow, from traditional to contemporary, from entertaining through moralizing, didactic and pedagogic to formative of opinion. As Hooft pointed out, literature was written and read but above all it was performed and spoken, and therefore watched and listened to. The ubiquity of communication across all layers of society primarily by means of performative literature meant that various literary interventions in social life were an ever-present channel through which erotic songs or drinking songs could circulate just as easily as political songs.

Given the questions we have asked ourselves, it seems best to set about the task pragmatically and define as literary texts all works in a form which we now categorize as literary (letters, poems, dialogues, stage plays, songs, etc.). Since we are concerned here with public opinion, our study will be limited to texts which were published, or written with the intention of being published, for a general public, and which aimed at informing, persuading or convincing that public. Moreover,

\footnotetext{
${ }^{27}$ For pamphlet dialogues like these see Dingemanse, Rap van tong, scherp van pen.
} 
they may have been circulated in both verbal and written form, as manuscripts or in print, circulated within formal or informal circles. ${ }^{28}$

Given the great variety of what we regard as recognizably literary ways in which authors expounded their opinions, some complicated and elaborate, some less complicated, it is pertinent to ask exactly why they opted for a particular form. The frequency and complexity of literary expressions used varied according to occasion and group. The type and sophistication of literary encoding were closely related to the sociocultural composition and geographical range of the audience, on the basis of which the author made a decision about the kinds of arguments he or she could make. ${ }^{29}$ Beyond that, an author might choose a specific form for mnemotechnical reasons, which would determine the impact of the text on the public in time (memory) and space (transfer). The fact that texts and formulations were given a literary form was one reason why they remained relatively unchanged when they were disseminated among larger groups, in handwriting, in print, but above all by recital. A writer might continue to give his or her work a more formal and intertextual character because he or she aspired to a more general articulacy that rose above contemporary disputes. Other literary characteristics too, such as rhyme, repetition and rhythm, could

${ }^{28}$ The concept of literature has been the subject of much debate. See for example Brillenburg Wurth and Rigney, Het leven van teksten, esp. pp. 46-47: 'we take the core of literality to lie in the fact that some texts have a value of their own that is unrelated to their single, practical deployment'. Abrams and Harpham, A Glossary of Literary Terms under 'Literature': 'designates fictional and imaginative writingspoetry, prose fiction, and drama. In an expanded use, it designates also any other writings (including philosophy, history, and even scientific works addressed to a general audience) [italics JB and $\mathrm{AvD}$ ] that are especially distinguished in form, expression, and emotional power'). Vrieler, Het poëtisch accent, pp. 18-20 gives the current position of research but sidesteps the problem somewhat. De Kruif, Meijer Drees and Salman, in Het lange leven van het pamflet, p. 11, say of the pamphlet in terms of content that it has 'a close relationship to early modern texts recognized as literary'. Hadfield, Literature, Politics and National Identity, takes a very broad conception of literature as its starting point.

${ }_{29}$ Pleij, Het gevleugelde woord; in addition, for historical research into the communicative role of songs see for example also: Fumerton, 'Not Home'; Darnton, 'An Early Information Society'; Freist, Governed by Opinion, pp. 125-76. There is no in-depth study into the communicative role of the song and other literary forms in the Low Countries, although in Het volle leven, passim, Van Stipriaan does offer a wonderful synthesis. For the role of the song in youth culture see also Grijp, 'Het Nederlandse lied in de Gouden Eeuw' and idem, Het Nederlandse lied in de Gouden Eeuw, pp. 29-30. 
lend a message a charismatic or prophetic character, and so be used to evoke a degree of authority. ${ }^{30}$

Many texts which were given a literary form were deployed to reflect upon, announce, defend, confirm or contest specific ideas, opinions, projects, forms of behaviour or situations. The use of literary forms had everything to do with the peculiarities of early modern society, which, no matter how far the written word had penetrated public life, was in many senses vitally dependent on oral and performative means of communication. ${ }^{31}$ In this context, the choice of literary forms affected the degree and breadth of impact that the creator of a text could achieve.

\section{The Habermas Model and Various Forms of 'PUblic SPHere'}

As we have seen, Habermas claims that in the late seventeenth and especially the eighteenth century a 'bourgeois public sphere' developed in which enlightened minds could freely express their opinions about matters of general interest. By doing so these enlightened spirits institutionalized social criticism; the consensus that arose from the discussions they had with each other developed into the institution of public opinion. ${ }^{32}$

Habermas regards the opinion-shaping press as an essential factor in the development of the supra-local communities within which a population needs to communicate if it is to form its own public opinion. Public opinion in this sense emerged not only from the press, but also from discussions in eighteenth-century salons, coffee houses and concert halls, and in clubs and societies. There, Habermas says, a cultured public of critical and rational individuals began to focus on the previously forbidden domain of the state and its policies. The critical nature of this new public meant it was no longer possible for the state to ignore the consensus that flowed from such discussions. Criticism

\footnotetext{
${ }^{30}$ For older literary texts, see for example Kay, 'Grafting the Knowledge Community'.

${ }^{31}$ Performative media include rituals, but also prose texts read aloud, poems recited, songs sung and theatrical performances, always closely bound up with social life.

${ }^{32}$ Habermas, The Structural Transformation. A useful summary can be found in Goode, Jürgen Habermas. Democracy and the Public Sphere, especially pp. 3-12.
} 
of art and literature by cultured individuals ultimately laid the basis for the rise of public opinion as a political authority. ${ }^{33}$

One problem with this is that even in the late Middle Ages and the early modern era, literary texts, and indeed paintings and music, were not the products of an autonomous artistic sphere whose purpose was enlightened amusement; rather they were part of a multimedia system, and most were extremely political, religious, moral or social in content. Habermas does not in fact deny that this was the case, but he assumes that the art of the pre-Enlightenment was always bound up with efforts by the authorities to represent their own interests and power. He argues that late medieval and early modern Europe had a 'representative public sphere' that did not bear even a remote resemblance to a supra-local public of involved, informed, independent and rationally-minded individuals that supposedly was created in Enlightenment Europe. ${ }^{34}$

To Habermas, broad participation in widespread literary culture was very much a matter of the printed word in newspapers and books, which were discussed in local communities. This stance has occasionally been contested. Without any reference to Habermas, Robert Scribner had already pointed to the importance of the oral transmission of ideas for the rise of the Evangelicals as a mass movement in the early German Reformation. He showed that ideas were disseminated in print and were then distributed widely through oral, performative, handwritten and visual media. This interaction between many different modes of communication made it possible for local communities to become part of a supra-local movement, and for the ideas of the Reformation to be lent form through individual acts by ordinary people at a local level. ${ }^{35}$

${ }^{33}$ Habermas, The Structural Transformation. For a summary of this part of the theory in relation to eighteenth-century Berlin, for example, see Schulte-Sasse, 'Einleitung'.

${ }_{34}$ Boone, "In den beginne was het woord" points to Habermas's theory and asserts (although in passing in a footnote) that Habermas was wrong to dismiss the appropriateness of the concept of public space for the medieval and early modern periods. Boone correctly claims that in this sense Habermas clearly reflects the academic knowledge of the time in which he conceived his work (Habermas based his dismissal primarily on Huizinga's classic Herfsttij der Middeleeuwen, published in English as The Autumn of the Middle Ages).

${ }_{35}$ Scribner, 'Oral Culture'. Scribner makes extensive use of the insights of social science into social movements, but not of theories about the public sphere and public opinion. 
In 1984 the social historian Rainer Wohlfeil entered the debate about the extent to which the German Reformation can be seen as an early form of the bourgeois public sphere, as defined by Habermas's criteria. Picking up on Scribner's findings, Wohlfeil argued that this particular supra-local movement in a largely oral and face-to-face society met the criteria of general accessibility and political relevance that would qualify it as a social movement and its participants as a public. It seemed to him, however, that this in itself was not sufficient to allow us to speak of a bourgeois public sphere. According to Wohlfeil, supporters and opponents of the Reformation mutually excluded each other. Rather than striving for a free, open, and rational debate, people wanted to convince their opponents of a revealed truth. ${ }^{36}$

The German Reformation was not the only period in which, for a limited time, a public debate blossomed, with large groups of people participating. Thus Briggs and Burke argue that we should distinguish between temporary (or cyclical) and permanent (or structural) public spheres. Among those that were temporary they include the initial phase of the German Reformation, the French religious wars of 1560 onwards, the Dutch Revolt of 1566 and subsequent years and the English Civil War of the 1640s, all of which occasioned pamphlet-explosions of their own. In their view it was only after the seventeenth century that the public sphere became permanent with the rise of newspapers and periodicals, which unlike incident-related pamphlets or oral and performative media appeared with reliable regularity. Despite their attention to the world of oral, theatrical, and visual communication, then, these social historians also see the printing press as an important motor in the development of a permanent public sphere. ${ }^{37}$

In their limited revisionism, Wohlfeil, Briggs and Burke judged that the modern phenomenon of public opinion, which according to Habermas can only exist because of a structured opinion-shaping press, had a longer lead-in time than he assumed for the period characterized by what he calls a representative public sphere. An increasing amount of work on forms of communication in various European

\footnotetext{
${ }^{36}$ Wohlfeil, 'Reformatorische Öffentlichkeit'. The term, here translated as 'Protestant public sphere', was invented by the Marxist historian Jürgen Schutte. In contrast to Habermas's bourgeois public sphere, the Protestant public sphere was closely bound up with temporary social movements like that of the German Reformation and, according to Wohlfeil, came to an end with the institutionalization of German Protestantism, when it became simply a denomination.

${ }^{37}$ Briggs and Burke, A Social History of the Media, especially pp. 102-04.
} 
regions has cast considerable doubt on the primacy of the printing press as a means of generating a supra-local public sphere. ${ }^{38}$ Inspired by this, we would claim that the early modern Low Countries had a permanent supra-local public sphere as a result of the interaction of handwritten and printed works with the oral, performative and visual media of a face-to-face society, and that in this interaction literary works had an important part to play. ${ }^{39}$

\section{FURTHER CRITICISM OF HABERMAS}

It is undoubtedly the case that with the rise of printing the regularity, speed, volume and reliability of news and the dissemination of information increased. Opportunities for critical debate in which arguments could be compared and verified, and very possibly also the rational quality of public opinion, grew as a result. Habermas goes further, however, by claiming that the rationality of individuals who debated together as equals, rather than the collective learning process, formed the basis of the new eighteenth and nineteenth-century bourgeois public sphere. We may well ask whether this individual rationality can be so straightforwardly ascertained, but Habermas lays himself open to criticism above all on the grounds that, taking his lead from the Enlightenment philosophers, he excludes other contributions to the social debate. Such contributions certainly did exist and can be shown to be relevant, if only because they make visible the issues that

${ }^{38}$ See the research into (for example) the political Reformation in Scribner, Popular Culture and Popular Movements in Reformation Germany; Duke, 'Dissident Propaganda and Political Organization'; Van Nierop, 'Popular Participation in Politics in the Dutch Republic'. Apart from work on the history of the Reformation, this is also clear from the study by Tilly into supra-regional revolts, although he does not look at the communication networks and collective opinion-forming that made such revolts possible. See for example Tilly, Contention and Democracy in Europe, 1650-2000.

${ }_{39}$ Elizabeth Eisenstein has pointed out that the rise of the art of book printing had a fundamental influence primarily on the world of scholars, who already had a book culture. It is often wrongly assumed that she did not take into account the fundamental role of oral culture in late medieval and early modern society. See Eisenstein, The Printing Press as an Agent of Change, vol. 1, pp. xi-xvi and 5-30 and especially 10. The relationship between the spoken, written and printed word outside the academic world is explored by, for example, Scribner, 'Oral Culture'; Fox, The Spoken Word and idem, Oral and Literate Culture in England 1500-1700; Pettegree, Reformation and the Culture of Persuasion. Like Eisenstein they emphasize that the spoken word was often written down or printed and the printed word was often read aloud. 
preoccupy a society. These may be religious convictions, norms, experiences, feelings or habits and customs, or they may be the grievances and vested interests of individuals and collectives. ${ }^{40}$

Historians hoping to find traces of the formation of public opinion should therefore not only focus their attention on literate and rational discourse between articulate individuals but look for other, less literate, rational and eloquent, indeed sometimes raucous forms of debate in which individuals and collectives were able to set themselves up as spokespeople and try to attract attention. The degree to which individuals and groups adhere to certain rules about the rational exchange of ideas is only one aspect of the public debate. ${ }^{41}$ Moreover, the requirement of rationality is a criterion that, no less than the appeal to authorities or cultural taboos, can be used as a weapon in an exchange of opinions to force anyone who is not a member of the dominant group to remain silent in public. ${ }^{42}$ It is, therefore, a rhetorical argument.

The idea that literary and artistic life in the late Middle Ages and the early modern era was closely bound up with government bodies has in any case been superseded. Social, religious and political movements in medieval and early modern Europe made use of relatively independent internal channels of communication to convey news, express criticism, mobilize and make visible oppositional forces, put pressure on the authorities and sometimes even to take political action. From this it is clear that a supra-local sphere of communication existed, which facilitated the circulation and digestion of news and ideas beyond the sphere controlled by the authorities. As we have seen, the live performance of music and rituals, and the public recital of textsranging from edicts and sermons to songs, poems and works for the

${ }^{40}$ Jäger, Öffentlichkeit und Parlamentarismus, pp. 70-71 criticizes above all the criterion of rationality and individual learning capacity, which overestimates the individual. Schulte-Sasse, 'Einleitung: kritisch-rationale und literarische Öffentlichkeit', p. 22, points out that not only Reason but moral and sensory experiences too are expressed in public (especially through literary texts). Moreover, Jäger points to nonliterary forms of protest such as marches, strikes and riots. Similar argumentation can be found in $\mathrm{Ku}$, 'Revisiting the Notion of "Public" in Habermas's Theory'.

${ }^{41}$ We understand the concept of a debate metaphorically here, given that we hardly ever come upon a direct debate alone, such as can take place between two or more persons.

${ }_{42}$ For this argument, see for example Fraser, 'Rethinking the Public Sphere', especially pp. $10-12$. 
stage-contributed to this supra-local sphere, alongside the material media of manuscripts and books, paintings and prints. ${ }^{43}$

Another problem with Habermas's model of the bourgeois public sphere is that it takes no account of the mechanisms of inclusion and exclusion that determine who is allowed to speak or to listen and who must remain silent in debates about matters of relevance to a given community, at the level of the state, a region, a town or even a neighbourhood. The public, which Habermas sees as made up of rational individuals, exchanging ideas on the basis of equality and developing a consensus according to who has the best argument, is itself no more than a subsection of society, namely male members of the higher bourgeoisie, who adhere to a specific norm governing the reciprocal exchange of views. It is impossible even for the bourgeois citizen himself to comply fully with that norm of rationality. Conversely, early modern societies included groups of people who strove for a form of public wisdom, such as humanists and other men of letters.

Habermas's model disguises the fact that in complex societies a battle is fought for ideological hegemony in the public domain, and the groups that make themselves heard the loudest and are the most visible to everybody else are the groups best able to put themselves forward as representatives of the public interest. To Habermas it does not matter whether such a group is the one most representative of the people as a whole, only whether it best serves the rational interest of the whole. The crucial question, however, is: how, and by which public, is this interest formulated? It is not a naturally existing fact: all kinds of economic, religious, cultural, moral, emotional and political motives contribute to the formulation of this interest. ${ }^{44}$

The notion of the public, a notion crucial to Habermas, presupposes interaction, participation and a degree of activity. ${ }^{45}$ It also assumes

\footnotetext{
${ }_{43}$ Briggs and Burke, A Social History, pp. 74-105; Pettegree, Reformation and the Culture of Persuasion; Marnef, Antwerpen in de tijd van de Reformatie, pp. 47-76.

${ }^{44}$ The general interest is always defined through mutual exchange. Again it is the dominant group that can use its ideas about the public interest to fend off other ideas from the opinion-forming and policymaking process by presenting them as reflecting the interests of specific groups. See also Fraser, 'Rethinking the Public Sphere', pp. 10-20 and for the Low Countries in the sixteenth century also Van Dixhoorn, "The Grain Issue of 1565-1566'.

${ }^{45}$ Sociologists and, following on from them, historians have strongly linked the concept of 'public', like the concept of 'masses', which by contrast assumes no interaction, participation or activity, to modern society. Rarely if ever is it used in an analysis of medieval or early modern society.
} 
the existence of a world in which specific institutions, persons and subjects are attended to, followed and featured in the news and in information supplied to others. According to Habermas the public consists of those who follow what is written in the press and exchange ideas about social issues. Since even in the Middle Ages and the early modern period people could become involved in an exchange of ideas about their society, by conversing with each other and through oral or performative and written literature, it is no longer tenable in an examination of the formation of public opinion to separate the early modern period fundamentally from modern times.

Moreover, Habermas uses an extremely strict definition of the public, which he presents as a single entity composed of individuals. In so doing he blocks our view of the various collectives that, using the means of communication available, can emerge within a society around themes, concerns and living conditions. Above all Habermas ignores the many forms of involvement in society as well as the many attempts to exert influence at a non-national level. ${ }^{46}$ At the same time he neglects the fact that in the early modern world too people operated as individuals and as such participated in informal networks and circles.

It seems, given this criticism, that it would be better to broaden the investigation and turn our thoughts to the identification, description, and analysis of the ways in which opinions are formed about specific social issues, and how they influence politics and society in various times and places, paying attention to all groups involved in the process and gaining greater insight as a result.

In this connection it might be useful to adopt Agnes Ku's proposal and define the burgher not in socioeconomic terms as a bourgeois individual, as Habermas does, but in the political-social sense of membership of a state and active participation in society, and therefore as a citizen. A shift from the notion of the bourgeois public sphere to that of the public sphere of the citizenry would point to concrete forms of political and social engagement by individuals and groups with different sociocultural backgrounds, interests, ideas and means of expression. ${ }^{47}$ Such an interpretation also produces a concept that

${ }^{46} \mathrm{Ku}$, 'Revisiting the Notion of "Public"'. Other examples include: Dunckelmann, Lokale Öffentlichkeit; Schulte-Sasse, 'Einleitung', p. 22; Splichal, 'Defining Public Opinion in History'.

${ }_{47} \mathrm{Ku}$, 'Revisiting the Notion of "Public"'. 
is less Eurocentric and more easily applicable to the study of social engagement in both historical and non-Western societies.

Habermas has created another analytical problem for those who study societies outside modern Europe and therefore also for historians. Critics have shown that he does not make a clear distinction between the public as a social reality (which he then goes on to identify too strongly with a single social group) and the symbolic public of public opinion that is regularly conjured up in political and social rhetoric whenever someone, or indeed a group, claims to speak on behalf of the whole population. Though he does not study concrete instances of social debate, Habermas believes that debates within a bourgeois public always lead to a real consensus, in the form of public opinion..$^{48}$

A presumed consensus under the heading of public opinion (or other concepts with the same import) cannot be a social reality, and is therefore a fiction. Public opinion as a unity or consensus is a symbolic construct, although it does have an actual impact on political rhetoric in that it helps to create moral authority for the state and for groups in the public sphere. In the battle waged to decide which people and ideas best represent that symbolic public (the battle, mentioned earlier, for hegemony in the public sphere), the real (always divided) public is naturally of great importance. The fiction even assumes the existence of an interested population that is capable of a discernible process of collective formation of opinion. ${ }^{49}$ Texts that take a literary form are extremely useful when it comes to imagining such a public. It is clear that in the kind of argumentative and didactic literary works that were produced in the early modern era, a public in this sense was indeed frequently conjured up. ${ }^{50}$

${ }^{48}$ Habermas, Strukturwandel der Öffentlichkeit. He does actually recognize a fictive element in the formation of public opinion, p. 69: 'Die entfaltete bürgerliche Öffentlichkeit beruht auf der fiktiven Identität der zum Publikum versammelten Privatleuten in ihren beiden Rollen als Eigentümer und als Menschen schlechthin', but he does not analyse that fictive element any further. A useful summary of his ideas about the development of public opinion in the eighteenth century can be found in Goode, Jürgen Habermas: Democracy and the Public Sphere.

${ }^{49}$ On the fictive element see Ku, 'Revisiting the Notion of "Public"'; Mah, 'Phantasies of the Public Sphere'; Splichal, 'Defining Public Opinion in History'; and Allport, 'Toward a Science of Public Opinion', especially pp. 51-54.

${ }^{50}$ See for example Schulte-Sasse, 'Einleitung', p. 22. For the role of literary techniques in the representation of the public see Baudin, 'The People in Seventeenth-Century 
Habermas's analytical blending together of the formation of the public as a social phenomenon, the formation of public opinion as a phenomenon of communication and interaction, and 'the public' and 'public opinion' as rhetorical elements within that process of communication points to a deeper problem. Habermas does in fact assume that the development of specific concepts like public opinion and the bourgeois public sphere have a direct relationship with socioeconomic and political developments. ${ }^{51}$ As we have demonstrated, Habermas has taken a rhetorical strategy used by a specific segment of the population, the eighteenth-century bourgeoisie, to be descriptive of the sociocultural reality that he then goes on to analyze. By recognizing the rhetorical function of concepts such as 'the public' and 'public opinion' and analyzing their effects on society, we can take an important step in the direction of a case-oriented analysis of the process by which public opinion is formed.

THE PUBLIC SPHERE, PUBLIC OPINION AND COMMUNICATION THEORIES

In the rest of this article we wish to develop a number of starting points for the concrete study of texts and the formation of public opinion. We will use social science studies that make it possible for historians to think beyond Habermas. These starting points are also intended to underline the need to make the inclusion of literary texts a standard feature of studies that investigate how opinions about social matters have been shaped.

Habermas's concept of opinion, which has been hugely influential in historical studies and in political and social philosophy, bears a very close resemblance to the classical-elitist definition that emerged from the Enlightenment. It regards public opinion as a consensus reached through enlightened and rational discussion within well-informed circles and made visible in the quality press. ${ }^{52} \mathrm{~A}$ more modern interpretation of public opinion can be found in definitions used in studies of

French Tragedy'; and more recently Hadfield, Literature, Politics and National Identity; Freist, Governed by Opinion, pp. 239-306.

${ }^{51}$ Habermas, Strukturwandel der Öffentlichkeit, pp. 16-78.

${ }^{52}$ For the classical-elitist conception see among others: Lippmann, Public Opinion; Lazarsfeld, 'Public Opinion in the Classical Tradition'; and of course Habermas, Strukturwandel der Öffentlichkeit. 
modern democracy or in the social sciences. They equate public opinion with the sum of opinions within a population..$^{53}$ Criticism of both definitions (that the one is too limited and the other too static) has produced a third. This sees the concept of public opinion as designating a dynamic process of opinion-formation that involves politicians, the media and a wide variety of interest groups, a complex phenomenon that can be found in one form or another in all societies. ${ }^{54}$ This definition has gained ground since the 1990s in work on the dynamics of the formation of public opinion and is particularly relevant to historical research. ${ }^{55}$

In both the classical-elitist and the postmodern definition, the concept of public opinion is closely related to the concept of a public sphere: public opinion is an observable phenomenon, whether the emphasis lies on the consensus (the fiction) or on the process by which opinions are formed. At first sight this seems rather less true of the modern democratic definition, since it includes opinions that people keep to themselves; it sees public opinion as 'the sum of opinions held by all people'. In its explanation of the way in which human opinions are formed and altered, however, the concept of a public sphere also arises immediately, not just because of the importance traditionally assigned to the media but because of a recognition of the relevance of political parties and social movements, and a realization that family members, friends and acquaintances are of crucial importance in the formation of opinion. The notion of a public sphere is closely connected to the public (or publics) in the sense of an audience or readership. As an object of research, 'public opinion' therefore includes the entire process of the formation of opinion within a specific public, of which public opinion as a fiction is an important element.

We can say something is public when specific speakers, consciously or not, communicate openly with an audience, the scope of which they

${ }^{53}$ This conception is at the root of the entire modern industry of opinion polling. See for example Converse, Survey Research in the United States. For a strict version of this concept of opinion see also Brettschneider, Öffentliche Meinung und Politik. For the history of the concept see also: Peters, 'Historical Tensions in the Concept of Public Opinion'; Zaller, The Nature and Origins of Mass Opinion; Price, Public Opinion; and Noelle-Neumann, 'Public Opinion and Rationality'.

${ }^{54}$ An early example of this assertion can be found in Mead, 'Public Opinion Mechanisms Among Primitive Peoples'. See also Noelle-Neumann, Öffentlichte Meinung.

${ }^{55}$ Kaase and Pfetsch, 'Umfrageforschung und Demokratie', especially p. 158. Crespi, The Public Opinion Process, pp. 114-26; Fishkin, The Voice of the People; Herbst, 'On the Disappearance of Groups'; Herbst, Reading Public Opinion. 
cannot entirely determine for themselves. Societies in which relatively free and intensive communication takes place between individuals and groups have a public sphere in which speakers and audiences can confront each other with their ideas on a regular basis. Where speakers and audiences encounter one another, be it in a physical or a virtual meeting place, speakers can express their opinions on specific subjects directly or through various media. The larger the audience, the less certainty a speaker has as to the effects of what he or she says. ${ }^{56}$

The public sphere is often conceived as a system of real and virtual meeting places: networks, institutions, theatres, coffee houses and societies, alongside newspapers, periodicals and other media. ${ }^{57}$ This approach regards the way in which the public sphere comes into being as highly dependent on such structures. The greater the sociability within a society, the more channels of communication and instances of communication it will have. The intensity of social life has a bearing on the public impact of what people and the media say. The way in which players in the public sphere are organized influences the form and range of a message. Anyone researching the public sphere along these lines will concentrate on the structural and infrastructural preconditions of its existence. This is a route that many historians have taken, especially those studying the late seventeenth and eighteenth centuries. Alongside this system-oriented approach, an actor-oriented approach is also possible..$^{58}$

An actor-oriented approach shifts the attention to the interplay between actors, in other words to the speakers and their audience, and its effects. In the communication process that produces a public sphere-public in the sense that it is generally accessible and visiblethe speakers involved fulfil specific social roles. Individual players and collectives, such as governments, businesses, churches, associations, pressure groups and media organizations, may act as authorities, experts, representatives, shapers of opinion or intermediaries. Depending on the occasion, players can switch from being members of the audience to being speakers and vice versa. ${ }^{59}$

\footnotetext{
${ }^{56}$ Neidhardt, 'Öffentlichkeit, öffentliche Meinung, soziale Bewegungen', especially pp. 7-8, with a reference to Habermas.

${ }^{57}$ Habermas, Strukturwandel der Öffentlichkeit; see also for example Van Vree, De politiek van de openbaarheid.

${ }_{58}$ Raupp, 'Zwischen Akteur und System'.

${ }^{59}$ Ibidem.
} 
The public sphere can therefore be seen as the outcome of social interaction between speaker and audience, whether direct, indirect or created by the media. In a social system, even one as uncontrolled and fragmented as the public sphere, all kinds of processes of integration and exclusion exist. The difference in roles assigned to players in the public sphere is influenced in part by the specific forms of knowledge and social capital that people have at their disposal. Not every individual can fulfil every role equally well. Some will be more capable of actively seeking out their own opportunities and conditions for communication and capitalizing on them. Others are more passive or may even be excluded by the chosen means of communication, the Latin language for example, from any possibility of receiving a particular message. Many other obstacles stand in the path of people hoping to act as speakers in specific ways, especially when it comes to the more organized roles in today's media. ${ }^{60}$

Communication that leads to publicity can be either verbal or nonverbal. The strategy chosen by a speaker for reaching an audience depends on the intended effect, the opportunities within the existing infrastructure, and the assessment the speaker makes of the expectations and potentials of the audience. Speakers can strive for maximum publicity, or they can aim at a more limited audience through a specific target group. ${ }^{61}$ Both formally and informally organized networks and channels can contribute to the creation of a public sphere. Formal publicity originates in the social interaction between institutional players and individuals and loosely formed groups. Informal publicity originates in daily contact between two or more people. Such contact is still one of the most important sources of publicity, but clearly in early modern societies it was the pre-eminent source. ${ }^{62}$

Every message that is made public is compiled in a specific code and made up of verbal or non-verbal signals. The recipients of a public utterance have to be able to decipher that code if the message is to be effective. Successful communication therefore also demands a shared knowledge of the language, symbolism and frameworks of interpreta-

\footnotetext{
${ }^{60}$ Raupp, 'Zwischen Akteur und System'; Westerbarkey, 'Öffentlichkeit und NichtÖffentlichkeit’.

${ }^{61}$ In practice, the audience of a message can never be unlimited, no matter how hard a speaker or his or her intermediaries try to reach as far and wide as possible. Raupp, 'Zwischen Akteur und System', pp. 121-22; Westerbarkey, 'Öffentlichkeit und Nicht-Öffentlichkeit', pp. 152-54.

${ }_{62}$ For the informal public sphere see Evers, Informele openbaarmaking.
} 
tion used between speakers, intermediaries and audience. The content of the message depends on both the level of knowledge of the speaker and his or her estimation of the audience. After all, the accuracy of the latter determines the message's effectiveness. Depending on its level of knowledge, the audience will be able to perceive, absorb, digest or reject the message in a more or less active way. This is quite important to the speaker and any intermediaries whom he or she may use. It is too simplistic to say that a speaker selects an audience, since the audience decides which message or which medium to pay attention to and how. Speaker and audience are therefore mutually dependent, and clearly the most ambitious and most engaged among them will compete for the most advantageous positions in the public sphere. ${ }^{63}$

Publicity is as continuous or discontinuous as the communication process from which it results. It undoubtedly gains in continuity when durable social relationships develop, since the players who shape the public sphere through their interactions develop fixed and recognizable roles, patterns of behaviour, and mutual expectations. An intensive social life and an extensive infrastructure are important preconditions. The tighter the formation of networks around the players, the more durable the public sphere will become, as a result of the intensity of communication within it. ${ }^{64}$ Studies of actors in a public sphere will therefore always have to take account of the space the public infrastructure offers them. Insight into the process of information provision and the formation of opinions and judgements in broad groups within a society will therefore always be dependent on an analysis that combines a focus on the structure and infrastructure with a focus on the actors.

\section{Media, PUblic issues ANd PUblic Debate}

When, in the endless stream of opinions and information in the media or in public exchange, or both, a single theme arises repeatedly, we can speak of a public issue, one that is generally known. A controversial

\footnotetext{
${ }^{63}$ Raupp, 'Zwischen Akteur und System', pp. 121-22; Westerbarkey, 'Öffentlichkeit und Nicht-Öffentlichkeit', pp. 152-54.

${ }^{64}$ For the early modern era see for example Wohlfeil, 'Reformatorische Öffentlichkeit' and Briggs and Burke, A Social History, pp. 102-04. On the importance of sociability see also (for example) Agulhon, Le cercle dans la France bourgeoise 1810-1848, pp. 7-14.
} 
public issue can lead to a broad exchange of views, in which case it will give rise to a public debate. It is possible to discern five phases in the development of public debates. In the first phase the problem is recognized by a group of people and crystallizes into a recognizable topic; those involved know what it is about and what their personal opinion is. In the second phase various possible solutions are explored and discussed. In the third phase groups crystallize, made up of advocates of specific solutions who then go in search of more support and try to create a broadly accepted consensus based on their own proposals. In the next phase the solution with the largest number of supporters or the greatest influence is carried through and put into practice, after which comes the final phase, the evaluation of the chosen solution and its effects. ${ }^{65}$ In addition, it may very well be that lasting public discord arises. ${ }^{66}$

In this model the formation of public opinion is a route by which people in a society can present social problems to each other, put them into words, and then look for solutions. The questions are: how did this happen in early modern society, and what part was played by literary works in the development, formulation, publication and recording of problems, arguments, proposals and social projects?

The role of the media merits closer examination. Research in communication studies in which the relationship between the public and the media is approached by means of three separate theories attributes to the latter a high degree of social influence. In our society the media are a constant presence and they exert great pressure on the public. This is not to say, however, that their influence is direct. People appear able to put up a great deal of resistance to direct influence by the media, mainly because they fit the information into their existing world of ideas and experiences and absorb news selectively, commonly through interaction with those close to them (the usersand-gratifications theory). Media influence is also dependent on other factors, such as public faith in the media, freedom of expression, the general level of education, prior knowledge, existing convictions, previous experiences, the intensity and quantity of media consumption and of social contacts, and the position of the media in the informal public sphere. But even people who have little contact with the discus-

${ }^{65}$ Price, Public Opinion, p. 31; compare Noelle-Neumann, Die Schweigespirale, pp. 219-20 (published in English as The Spirals of Silence).

${ }_{66}$ Neidhardt, 'Öffentlichkeit, öffentliche Meinung, soziale Bewegungen', pp. 7-8. 
sion of issues in the formal media and have strong convictions of their own will notice the influence of the media, unless they are completely isolated socially. ${ }^{67}$

The media select the news and information that will be disseminated most widely, they decide which persons, bodies and groups, and which arguments, will most often be heard and seen, and within which frameworks of interpretation this will take place. So they have a huge influence on the social agenda. Conversely, people, groups and bodies within a society have an influence on the media agenda (the agendasetting theory). The less freedom the formal media have, the greater the role of informal circles, which fulfil the same agenda-setting function. The media expand the reservoir of knowledge, opinions and arguments, and they strengthen interaction within the involved and active public. They have an impact even if only a small group becomes aware of the message, since there is a fair chance that this small audience will in turn share its knowledge and insights with others. In societies where the media cannot disseminate messages to a broad audience, those who do receive media input seem to play a particularly important role in funnelling knowledge and insights onwards (the two-step-flow theory).$^{68} \mathrm{~A}$ similar notion has been formulated for the early modern period in relation to intermediaries between the culture of the literate elite and popular oral culture. ${ }^{69}$ These intermediaries are sometimes called opinion leaders. ${ }^{70} \mathrm{~A}$ different group of opinion leaders is active within the organized media. ${ }^{71}$

\footnotetext{
${ }^{67}$ Stappers, Reijnders, Möller, De werking van massamedia; Schenk and Rössler, 'Das unterschätzte Publikum'; Zaller, The Nature and Origins of Mass Opinion; Lenart, Shaping Political Attitudes, pp. 98-108; Glynn, Ostman, and McDonald, 'Opinions, Perception, and Social Reality'; Page and Shapiro, The Rational Public; NoelleNeumann, Die Schweigespirale.

${ }^{68}$ Stappers, Reijnders, and Möller, De werking van massamedia, pp. 189-91; for the two-step-flow theory of two pioneers of modern opinion research see Katz and Lazarsfeld, Personal Influence.

${ }^{69}$ Vovelle, 'Culturele tussenpersonen'; Frijhoff, Wegen van Evert Willemsz.

70 Price, Public Opinion, pp. 200-01 refers to the well-known study by Moscovici, which has shown that the 'conversion' of people who take up central positions in interpersonal networks was a key step in the process of diffusing agricultural and technological innovations. Comparable findings are in Katz and Lazarsfeld, Personal Influence, where the role of opinion leaders (those who are first and most thoroughly exposed to influences from the mass media) are central to social groups. For a historical application of their theory see Scribner, 'Oral Culture'. On the role of people with strong convictions see Billig, Ideology and Opinions, pp. 190-92. See also Maczkiewitz, Die niederländische Aufstand, pp. 194-96.

${ }^{71}$ Noelle-Neumann, Die Schweigespirale, pp. 200-05, 222-40; Converse, 'The Nature of Belief Systems in Mass Publics', on the role of political parties and an elite
} 
All three of these models assume interaction between media and public, whether the public fits messages from the media into its existing world of ideas and experiences, influences the media agenda, or passes on knowledge and insight to others. The question is: how, in the light of this, should we assess the importance of literary texts whose function in the early modern era resembled that of the media today?

\section{THE EARLY MODERN PUBLIC SPHERE}

As we have seen, the early modern public sphere was characterized primarily by informal networks in which news and opinions were formed and disseminated. ${ }^{72}$ Institutional players in the public domain were the various governmental bodies, the churches and other religious organizations, educational institutes, literary societies and, of course, printers. In a certain sense public festivals, ceremonies and competitions, which local communities organized regularly in the late medieval and early modern periods, also formed an institutionalized public sphere that presented plenty of opportunities for theatrical performances, the reciting of verses and the singing of songs. The social character of these events ensured at the same time that they amounted to meeting points in informal public spheres. ${ }^{73}$

In the late Middle Ages and the early modern period at least, the public provision of news and the formation of public opinion were collective projects to which many individuals contributed and which operated through an informal web of individual conversations, private correspondence, leaks of secret information, and perpetual guesswork and deductions based on available facts, personal experiences and frameworks of interpretation. The more formal media landscape was organized very differently to the way it is today. Until the early seventeenth century there were no periodicals, newspapers or magazines producing news in a structured manner. Newsgathering was the work

public as opinion leaders. The literature on leadership of opinion in the formal media is, as far as we can see, limited. For the early modern Low Countries see Van Dixhoorn, Lustige geesten, pp. 255-423; and idem, 'Soorten rederijkers'.

72 One famous story is that of Hugo Grotius's escape from Loevestein, a tale that was known throughout the country within a few days. See Nellen, Hugo de Groot, p. 260.

${ }^{73}$ Van Dixhoorn, Lustige geesten, pp. 301-43; idem, 'Liefhebbers van de redekunst'; Van Bruaene, "A wonderful triumfe, for the wynnyng of a pryse"'. 
of the public itself and the publication of news in print was done on an incidental basis. To the extent that news and opinion were disseminated by means of the printing press (in the form of pamphlets and newssheets), authors, printers, publishers and the book trade formed the editorial system that chose which items to publicize and expressed opinions on them.

Merchants, innkeepers, diplomats and government officials in particular were continually looking for news as part of their social function. Until well into the seventeenth century, however, there were too few people seeking out domestic news, information and opinions to warrant publishing them regularly. Newsgathering was mainly in the hands of interested parties and of inquisitive and well-informed members of the public who had close ties with each other and access to the right sources. Because they determined what kind of information they deemed important to collect, they had a crucial editorial function in the mainly oral process of forming public opinion and deciding which events were newsworthy. ${ }^{74}$ The other media were closely involved with this oral world. The formation of opinion and the provision of news and information could take place through the recital of poems, the singing of songs and performances on stage, as well as through the organizing of tableaux vivants and displays of images at official ceremonies. News, information and opinions were also distributed in the form of written and printed texts, paintings and prints, stained glass windows, clothing and rituals. The educated and the illiterate, holders of power and private persons all made use of these media to disseminate their opinions. Many had access to these opinions as long as they attended certain events, or could appreciate written works either because they were able to read or because people around them were willing to read aloud. But be it through the stage or the written word, ideas could be spread further because after the performance or the reading they were discussed. ${ }^{75}$ It seems that at times of growing public debate the

\footnotetext{
${ }^{74}$ For early modern systems of news, oral or otherwise: Cust, 'News and Politics in Early Seventeenth-Century England'; Fox, 'Rumour, News and Popular Political Opinion'. For the Low Countries see Van Nierop, "'And Ye Shall Hear of Wars and Rumours of Wars"'.

${ }^{75}$ Most of the assimilation may in fact have taken place at this stage. See Eversmann, 'The Experience of the Theatrical Event'.
} 
number of opinion leaders increased, the media expanded, new media spread more quickly, and old media became easier to revive. ${ }^{76}$

In the Low Countries from the mid fifteenth century onwards, supralocal literary networks developed, made up of learned individuals and 'amateur scholars' within the local chambers of rhetoric. There all sorts of matters of public opinion were placed on the agenda and discussed, so that the chambers fulfilled an editorial function, as it were, within a communication system that bound together the oral and visual world with that of the written and printed word. ${ }^{77}$

An important role in the development of public controversy is reserved for those who do not keep an opinion to themselves, since they believe it to be of concern to others as well. They therefore place it on the public agenda, thus taking the initiative in describing a public concern. As we have seen, a public issue arises only when others recognize the problem and make it their own, at which point a discussion can begin as to the description of the problem and its solution. Such processes of collective formation of opinion grow more complex as a society becomes more complicated, and with it the problems about which people have to form judgements. ${ }^{78}$ In order to recognize collective (public, generally accessible and known) problems and to be able to solve them, people need access to the relevant channels of knowledge and information. This brings us back to the oral circle that was crucial to early modern society. As news is passed by word of mouth it is continually 'edited' as information is removed, supplemented, revised and reformulated, so that the message is composed of the knowledge and opinions, both implicit and explicit, of all those who give shape to it. ${ }^{79}$

In contrast to meetings of small groups, in a society that transcends the local level it is hard to determine how many people hold a particular opinion. If the matters involved are controversial it soon becomes

\footnotetext{
${ }^{76}$ Van Dixhoorn, Lustige geesten, pp. 89-91; Briggs and Burke, A Social History, pp. 102-04.

77 Van Dixhoorn, Lustige geesten, pp. 257-63. For the mechanics of news networks, domestic or international, of learned people in the early modern Republic see also (for example) Stegemann, Patronage and Services in the Republic of Letters, p. 435.

${ }_{78}$ Habermas correctly pointed this out. For a brief overview of the different phases in the public debate see also De Boer and 't Hart, Publieke opinie, pp. 43-45; NoelleNeumann, Die Schweigespirale; and Neidhardt, 'Öffentlichkeit, öffentliche Meinung, soziale Bewegungen'.

${ }_{79}^{79}$ See also Darnton, 'An Early Information Society'.
} 
even more difficult. Assessing which standpoints are supported by a majority or by a minority is crucial to the dynamics of the process of opinion-formation. In early modern societies, however, it was enormously difficult to tell how widely represented a given view was, and for historians it is no easier to determine this. People and groups undoubtedly observe and judge each other all the time, and in addition they look at how institutions deal with issues, forming judgements about them on that basis. This observation and judgement of others ultimately forms the core of the process that creates public opinion. ${ }^{80}$ And it is in this process that the 'fiction' of public opinion, and the fiction of a public that would agree with an opinion, arise. Through what people hear others say, through what they see and read (and tell others about) they form an impression of what 'the common folk', 'people', 'one', 'everybody' or 'the community' thinks. ${ }^{81}$

Literary texts were of great significance in the creation of the early modern fictive public. Whether a text reflects a broadly held opinion or the opinion of one individual, as soon as that opinion is presented as a broadly held belief or consensus, that very fiction in itself helps to form opinion. To take a simple example, when Leiden rhetorician Jacob Duym stood up in favour of continuing the war against Spain in his Moordadich Stuck van Balthasar Gerards (Murderous Act of Balthasar Gerards, 1608), by presenting the attack on William I, the 'father of the fatherland', as a foul murder committed at the instigation of the Spaniards, he made it seem as if the general attitude to Spain was extremely negative. ${ }^{82}$ In the play, the trio of Spanish Council, Bloodlust and Inquisition incite Balthasar Gerards to the murder of Orange. The identification of Spain with tyranny was, of course, meant to fuel dislike of Spain. Whatever influence this play may have had on the

${ }^{80}$ A fundamental analysis of the role of observation in the process of opinionformation can be found in Noelle-Neumann, Die Schweigespirale. See also: Darnton, 'An Early Information Society'; Farge, Subversive Words; Fox, 'Rumour, News and Popular Political Opinion'; and Van Nierop, " "And Ye Shall Hear of Wars and Rumours of Wars"'.

${ }^{81}$ Interesting examples of the process of weighing up the opinion of 'the community', etc., in the early modern Low Countries can be found in chronicles. See for example Van Haecht, De kroniek van Godevaert van Haecht over de troebelen van 1565 tot 1574 te Antwerpen en elders, ed. Van Roosbroeck; Chronycke van Antwerpen sedert het jaer 1500 tot 1575; Van Vaernewijck, Van die beroerlicke tijden in die Nederlanden en voornamelijk in Ghendt, 1566-1568, ed. Vander Haeghen.

${ }^{82}$ See Duym, Het Moordadich Stvck van Balthasar Gerards, ed. Serrarens and Wijngaards. 
formation of opinion about the peace and on the actual negotiations, the fact is that in the years before 1609 the aim was not lasting peace but a temporary truce. The play was one of the voices that created the public climate in which the negotiators had to operate. How and to what extent they were truly influenced by it is another matter. ${ }^{83}$

In 1619 Job A. van de Wael, factor at the Flemish chamber of rhetoric 'De Akerenboom', wrote a play called Schiedams Rood Roosjens Spel, van David ende Goliath (Schiedam Play for Red Rose, of David and Goliath). It was his entry for a competition held by the Schiedam chamber 'De Roode Roosen'. ${ }^{84}$ At a time when the disputes between Maurits and Oldenbarnevelt, between Remonstrants and CounterRemonstrants, and between the parties favouring war and peace were approaching a conclusion, Van de Wael had written a play in which Maurits was valued positively; like the biblical King David who saved his people by defeating the giant Goliath, Maurits would defeat the godless giant Spain and thereby save the Dutch. David and Maurits were compared in an implicit but barely concealed manner. Readers would have had no difficulty arriving at this interpretation, since the printed version of the play was dedicated to Maurits and it had been written for a competition in which the question set by the Schiedam chamber for entrants to answer was:

What honour belongs to a Prince who engaged his enemy

Triumphed by force of arms and brought peace to the community? ${ }^{85}$

The parallel between David and Maurits is reinforced by paratextual means: a choir of Israelite women sings a song of praise to David in the style of the Wilhelmus. ${ }^{86}$ Van de Wael was showing very clearly which side he was on and was attempting to identify his personal preference with the general interest.

Duym's reference to the 'Spanish Inquisition' and Van de Wael's reference to the myth of a Dutch Israel point to another important

\footnotetext{
${ }^{83}$ See, for instance, Groenland, 'Toneel als pamflet?'.

${ }^{84}$ See Bloemendal, 'König von Gottes Gnaden?'. For Van de Wael see (for example) Van Dixhoorn, 'Liefhebbers van de redekunst', especially pp. 27-28.

${ }_{85}$ 'Wat eer den Prins behoort, die syn vyandt bestrede, / Met Waep'nen overwon', en braght 't gemeent' tot vrede?'

${ }^{86}$ The Wilhelmus, which has now become the national anthem of the Netherlands, was a popular Orangist song created by an anonymous poet in the tradition of the rhetoricians and for or in the circle of William of Orange. There is debate as to its author, the time of its origin and the aim of the song.
} 
function that literary texts fulfilled in the formation of opinion. They helped to develop and disseminate frameworks, templates and stereotypes by means of which an interested public could interpret the world, explain social developments, identify standpoints and groups and decide which party they preferred. Since it was difficult for governments to estimate the effects of such texts, it is conceivable that in some way or other they took account of publicly expressed views like these in deliberations at the highest level. Moreover, the political elite was itself part of a public that read, listened and conversed. Its members could therefore be directly addressed and influenced by arguments and formulations, and by the climate of opinion, fictive or otherwise, represented in literary works.

The fictive public conjured up here is a real factor in the process of opinion-formation because majorities have an important legitimizing and moralizing function and contribute to social pressure. Views that are successfully presented as those of 'the public' may very well correspond to those of an actual majority-but not necessarily. The fictive public that is made visible in public exchange and 'observed' in private therefore complicates the dynamics of public opinion considerably. ${ }^{87}$ We believe that historians should be aware that this fictive public existed even before 1700 and was powerfully portrayed in literary works in particular, whether they were disseminated in a written form or by being sung, recited or acted.

\section{AN APPEAL IN RHYME TO THE PEOPLE OF MECHELEN}

While in stage scripts like those by Jacob Duym and Job de Wael various ideas could be weighed up at the same time, in their incisive ballads, pointed songs, didactic ballads and other forms of verse, authors often took a more clearly defined stance. A manuscript from Mechelen, now in the British Library, consists of a collection of documents on how a 'revolt' arose against the 'natural prince' ${ }^{88}$ Additional coherence is given to this collection of political and governmental documents (letters, placards, edicts and petitions) by the poems interpolated between them, such as a pasquil and a ballad from 1567, which comment upon

\footnotetext{
${ }^{87}$ Compare Mah, 'Phantasies of the Public Sphere'.

${ }_{88}$ British Library, Additional Manuscripts, 18, 291. Copies of official letters and papers relating to the War of Independence in the Netherlands from 1566 to 1578.
} 
events. ${ }^{89}$ One of these poems entitled Advertissement ende loffelycke vermaninghe aen die goede catholycke borghers van Mechelen gedaen doer medelyden vanden zeer vermaerden ende oude Philosooph Pasquil van Roome (Warning and praiseworthy exhortation to the good Catholic citizens of Mechelen given out of sympathy by the very illustrious and old Philosopher Pasquino of Rome), rants and raves against the geuzen (the 'beggars' or rebels) and the calfsteerten ('calf-tails' or Calvinists). The Catholic citizens of Mechelen are taken to task, and in doing so the writer examines various ideas that must have been doing the rounds in the town (or at least, the writer believed them to have been). In the process he explains to his fellow citizens why, in his opinion, they did not make a stand against the destroyers of images, even though he believes the iconoclasts were nothing more than a small 'bunch of rogues', and despite the fact that the Catholics were vastly in the majority. The Advertissement is a powerful plea to take up arms to defend the church and the king.

The Advertissement, which is signed 'Schellart Willet Doorgronden' (roughly Schellart Wantsto Fathomit), was probably never printed. The warning was very likely meant to be read or heard by the Catholics of Mechelen and it may have been read out in company or circulated in manuscript. ${ }^{90}$ By analyzing the outbreak of iconoclasm in Mechelen in 1566, a countrywide phenomenon known as the Beeldenstorm, it attempts to rouse the Catholic population into taking action against the beggars when necessary. The author presents the Catholics as people who think and act collectively and can be duped, convinced by arguments, held responsible, and called upon to take action. In short, Schellart addresses the Catholic citizens of Mechelen as a moral body.

${ }^{89}$ The term pasquil or pasquinade refers to an anonymous lampoon, often in rhyme. The pasquil takes its name from an ancient statue that was discovered during excavations in Rome in 1501 and freshly erected. Rome's residents started to hang anonymous Latin verses on it.

${ }_{90}$ E. van Autenboer, 'Een pamflet over de Mechelse beeldenstorm. Overdrukje Mechelse Bijdragen (1949)', refers to a Schellart-collection whose whereabouts were unknown to him at the time. With thanks to Prof. Judith Pollmann (Leiden) for this reference. It can now be ascertained that this collection is identical to the Papemanuscript which he also cites, and is the one now held in the British Library. Autenboer has edited the poem in a version from the Mechelen city archives that is a transcription from the manuscrpt now in the BL. Interestingly, Autenboer also refers to a list of books confiscated in Mechelen in 1568 containing a 'Pasquile addressant aux bons et catholicques bourgeois de Malines'. 
Schellart deploys literary resources to deal with a public issue. ${ }^{91}$ The letter in rhyme, supposedly written by the Roman philosopher Pasquillus (known to the English-speaking world as Pasquino), broaches what was for Catholics a pressing matter, defines the problem, treats the arguments, rebuts objections, informs the audience, and tries to convince people and even prompt them to act. So the Advertissement should be seen as part of a social debate. Texts like this pasquil, once in public circulation, fulfilled the same function in the public sphere as printed pamphlets and tracts, which were on the rise from the 1560s onwards. Until well into the seventeenth century, literary genres which were developed in an oral and performative context and then appeared in print, including fictional dialogues between allegorical protagonists championing specific standpoints and all kinds of rhymed pleas, commentaries and attacks, continued to lend form to the public exchange of ideas.

One complicating factor is that not all extant opinion pieces and written arguments were intended for public consumption, whether by means of handwriting, printing, performance or recitation. Works that were so intended (which we should probably assume to be the case with the Mechelen text) may have remained in portfolio or have reached only a very small group. Even so, they represent vestiges of individual opinions on arguments about general issues, or ways found by individuals to deploy those arguments. In this sense too, a text can be used as a source for historical research into public opinion. The Mechelen example also shows very clearly how, in a literary work with fictional elements, the fictive public can be given a definite shape (in this case presented as a majority that allows itself to be 'captured' by a minority) and called to account, fiercely criticized and urged to act.

\section{THE FUNCTION OF LITERARY TEXTS IN PUBLIC OPINION: A MODEL}

It should in any case be clear that literature, in whatever precise way we use the concept and however broadly or narrowly we define the term, has a hand in the process of forming public opinion and indeed the formation of a public. Literary texts can do this in various ways.

\footnotetext{
${ }^{91} \mathrm{He}$ was concerned about a problem (the supposed passivity of the Catholics of the Low Countries), which still occupies the minds of historians today. See Pollmann, 'Countering the Reformation in France and the Netherlands'.
} 
They can air specific opinions and so, as trendsetters, put specific matters on the agenda, or, as followers of a trend, put a given consensus into words in specific circles. A literary work can reflect the opinion of a single individual or a small group, and at the same time it can claim to represent the opinion of a larger group or groups (the mouthpiece function). In the early modern Low Countries, authors could readily deploy literary works, since they were usually operating within local communities, the chambers of rhetoric, where specific topics were discussed during meetings. The chambers in turn were in contact with other chambers, so that supra-local and supra-regional networks developed. Furthermore, the rhetoricians were in contact with other groups in the cities, such as printers and scholars, and with all kinds of other social groups, so that specific ideas could be handed on via their own networks as well. Gradually, therefore, through a combination of formal and informal circles, a well-informed public of 'right-thinking' citizens positioning themselves as moral guides of the community came into being. Humanist scholars who wrote and taught in Latin were also part of it.

Literary works could be deployed alongside this kind of public discussion. They were written and read, but above all spoken and heard and performed and watched. This often happened in consultation with local or supra-local authorities but also independently. The rhetoricians sometimes presented themselves as representatives of the government and actively contributed by producing plays, ballads and tableaux vivants at the Blijde Inkomsten (the Joyous Entries or first official visits of new rulers), but they were just as likely to express direct or indirect criticism (especially in songs and ballads) of the government, the church and its representatives, the community and dominant beliefs, religious or otherwise.

If an opinion is cast in a literary mould, this affects the manner in which we need to study it. The creation of a literary work requires such mental effort, such skill and such knowledge (of other literary texts, for example) that the opinion or opinions contained in it-in literature various opinions can of course be expressed alongside each other or in combination-are shaped, refined, and altered during the creative process.

In this way, literary texts can open minds to varied possibilities that are closed in reality, to all kinds of openings for change or indeed for stabilization. They can do this by means of their content, but sometimes the writing and publishing of a literary work is in itself a statement. The French Jesuit Nicolas Caussin wrote his Latin plays 
about biblical subjects and the lives of the saints at a time (the early seventeenth century) when the Jesuits in France were in an awkward position: they were regarded as critical intellectuals and as such their movements were restricted, but he was thereby able to demonstrate the vitality of his order. ${ }^{92}$

Literature shapes public opinion in another way too. It offers all kinds of narrative strategies, rhetorical devices and basic plots within which events can be recounted and interpreted. ${ }^{93}$ In other words it provides an arsenal of media techniques and a repertoire (allegory, dispute, conversation, oration) that can be deployed to influence the public debate. Literature therefore enables others, including those outside the formal public sphere, to follow an author's example and state their own opinions more forcefully.

Up to now we have identified seven functions of literary works in the process of forming public opinion. They can: 1) put something on the agenda; 2) announce, confirm or contest specific opinions and add arguments to a debate; 3 ) be used for instruction, for the provision of information, and to raise the level of knowledge of the public; 4) serve as a civilizing tool and equip citizens and others to express their opinions effectively in words; 5) assist in the formation of groups (as did psalms, martyr songs and rebel songs); 6) be deployed in a process of self-fashioning and self-presentation to become a leading opinion maker; and 7) be used to prompt people to behave or take action in a certain way.

Through the use of dialogue and debating techniques, many early modern literary works also made the social debate, its main themes and arguments and the main players within it visible to a broader public. Literary culture can be seen as a breeding ground for ideas in the sense that in early modern texts boundaries are often explored (and regularly transgressed). Authors of literary texts often experimented with forms and viewpoints, while ideas from other circles or other regions were adapted for local voices through local literary works. Conversely, local voices could be adapted for inclusion in Latin texts aimed at an international audience.

\footnotetext{
92 See Chevalier, 'Le châtiment de la démesure: les tragédies bibliques de Nicolas Caussin' and Valentin, Les jésuites et le théâtre (1554-1680), pp. 489-95.

${ }_{93}$ Compare Fox, 'Rumour, News and Popular Political Opinion', which points to the impact of basic plots disseminated through popular literature on the political imagination of the British public.
} 

CHAPTER TWO

'YOU SERVE ME WELL':

REPRESENTATIONS OF GOSSIP, NEWSMONGERING AND PUBLIC OPINION IN THE PLAYS OF CORNELIS EVERAERT*

\author{
Samuel Mareel
}

'You serve me well' ('Ghy zyt die my naer tbehooren dient'), a character called A Certain Rhetorician ('Sulc Rhethorisien') remarks to Everyday Chitchat ('Den Daghelicxschen Snaetere') at the beginning of the sixteenth-century Dutch rhetorician play dOnghelycke Munte (The Uneven Currency). A Certain Rhetorician subsequently invites Everyday Chitchat, who is dressed as a huckster selling apples, to mount the stage and be part of the play that he is about to perform in honour of the Peace of Cambrai (1529) and the coronation of Charles V as Holy Roman Emperor (1530). In accordance with her name and attire, throughout the play Everyday Chitchat voices bits of news and opinions that supposedly circulated in Bruges regarding the events celebrated.

Although we should obviously be cautious in identifying the author of The Uneven Currency with the A Certain Rhetorician character simply because they share the same literary pastime, there are some grounds to attribute autobiographical content to the line quoted above. The play was written by the Bruges rhetorician Cornelis Everaert (ca. 1480-1556), a dyer, fuller and clerk by profession and a member of the two chambers of rhetoric from Bruges, The Holy Spirit ('De Heilige Geest') and The three (female) Saints ('De Drie Santinnen'). The Uneven Currency came down to us as part of a group of 35 dramatic texts that the author copied out in a single manuscript. They constitute

* This article was written while being a recipient of a Fellowship of the Belgian American Educational Foundation at the University of California, Berkeley. I wish to thank Dirk Coigneau, Timothy Hampton and Alan E. Knight for their useful comments on earlier versions of this text and Joseph Jay Williams for logistical support. 
the largest number of extant plays by one single Dutch rhetorician known by name. ${ }^{1}$ Like A Certain Rhetorician, Everaert does indeed seem to have been fond of using the news and gossip that circulated in the streets and on the squares of his hometown as material for his plays. Three of the texts in his autograph contain allegorical characters whose names and/or actions refer to the spreading of news and the commenting on the current political, social and religious situation. Most of the events discussed are related to the so-called Italian Wars, a series of military conflicts that opposed the houses of Habsburg and France and that had serious repercussions for economic and social life in Bruges. ${ }^{2}$ It was for the public celebration of the successes of Charles V in the Italian Wars that Everaert wrote the plays. Ghewillich Labuer ende Volck van Neerrynghe (Willing Labour and People of Commerce) glorifies the Peace of Madrid of 1526, the aforementioned The Uneven Currency the Peace of Cambrai (1529) and the coronation of Charles V as Holy Roman Emperor (1530), and Pays (Peace) the gathering of Charles $\mathrm{V}$ and Francis I at Aigues-Mortes and the ensuing Truce of Nice (1538). Most of these festivals were organized by the Bruges city government at the instigation of the central authorities. The dramatic performances that adorned them generally took place in the context of a competition during which theatre groups, generally chambers of rhetoric, competed with one another.

Scenes in which characters discuss political matters were not uncommon in late medieval and early modern Dutch dramatic texts, the most famous being probably the one in the generically hybrid prose novel and drama Mariken van Nieumeghen (Mary of Nijmegen) where Mary's aunt vehemently discusses a conflict between Duke Arnold van Gelderland and his son Adolf. The woman gets so excited that, according to the text, she resembled more a devil than a Christian woman. ${ }^{3}$ Plays like the ones by Everaert under discussion here-which do not just give evidence of the existence of practices of popular newsgather-

${ }^{1}$ Brussels, Royal Library, ms. 19036. Everaert's plays have been edited by Muller and Scharpé, Spelen van Cornelis Everaert, and by Hüsken, De spelen van Cornelis Everaert. For what is known about the life of Everaert and the genesis of his autograph, see the introduction to these editions. The quotes in this article come from the Hüsken edition.

${ }^{2}$ On the effects of the Italian Wars on the Bruges economy, see Vandewalle and Vandamme, 'Het Spaanse Brugge, 1490-1600'; Blockmans, "Fondans en melencolie de povreté": Leven en werken in Brugge 1482-1584'.

3 Coigneau, Mariken van Nieumeghen, p. 58. 
ing and public opinion but allegorize them, thus turning them into a central and integral part of their argument-are rare, however. What makes them so interesting is that they do not just illustrate popular newsgathering and public opinion but also offer us insight into the way in which the nature and the working of these phenomena themselves were perceived, how and why they could be used in a literary text and how this text, in turn, functioned in the processes that it represented.

Through characters such as Everyday Chitchat, Everaert's plays suggest a lively informal circulation of political news-which had often travelled a considerable distance-in sixteenth-century Bruges. In Willing Labour and People of Commerce, Consoling Assistance ('Troostich Confoort'), a character dressed as a sailor, announces 'something new' ('wat nyeus', 1. 143) to the duo Willing Labour and People of Commerce, who have been lamenting the disastrous consequences of the Italian Wars. Before he came sailing from Spain, Consoling Assistance heard people mention that peace had been declared. It was said that the French King had taken Eleanor, the Emperor's sister, as his wife. The announcement is disputed vehemently by Turbulent Times ('Den Beroerlicken Tyt'). He points to the frequency with which bits of news of this kind were spread, the avidity with which they were received and their uncertain veracity:

Hearsay counts as a lie to me, because people lie all the time going from door to door as anyone can notice on many an occasion.

By Saint Louis, buddy, you are talking bunkum.

It is merely to get a tip that you are saying this. (1l. 171-75) ${ }^{4}$

The same impression of an active passing on of bits of news and gossip is put forward by the opening scene of Peace, in which, eight years after The Uneven Currency, Everaert reused the character of Everyday Chitchat. This time she is selling hazelnuts instead of apples and is accompanied by The People's Gossip ('sVolcx Clappage'), a labourer.

4 'Thooren segghen achtich als een luere, / want men liecht daghelicx van duere te duere / so elck mercken mach te meneghen stonde. / By Lo, maet, ghy speilt ooc metten monde. / Om dryncghelt thebbene maect ghy dit voortstel.' 
Everyday Chitchat and The People's Gossip introduce themselves to one another and to the public:

\author{
Everyday Chitchat \\ What's your name? \\ The People's Gossip \\ The People's Gossip,
}

I am everywhere: on the land and on the sea.

But how are you called?

Everyday Chitchat, Everyday Chitchat

who can talk about anything.

We belong together,

The People's Gossip

Everyday Chitchat and The People's Gossip.

We have something exceptional to say about everything:

of this person, of that person, of here or there.

Everyday Chitchat

Of happiness, of sadness.

The People's Gossip

Of light or heavy matters,

of what goes on far away or nearby, we know it all.

Everyday Chitchat

Whether something is public or secret,

the moment we start talking about it

the whole world will know about it right away.

That which we know nothing about, we will keep a secret.

The People's Gossip

We will not tone down anything.

Everyday Chitchat

We will not leave anything out.

We would rather embroider something than trivialize it. ${ }^{5}$ (1l. 25-40)

Political news was not just spread and received as such but also heavily commented upon, Everaert's plays suggest. After the excerpt from

\footnotetext{
5 'Den Daghelicxschen Snaetere Hoe es uwen naeme? / sVolcx Clappage sVolcx Clappage, / die my allomme scicke: te lande, te watere. / Maer hoe heet ghy? / Den Daghelicxschen Snaetere Den Daghelicxschen Snaetere, / die alle dynck can vercombienen. / sVolcx Clappage Wy zyn juuste die tegare dienen, / den Daghelicxsche Snaetere ende sVolcxs Clappage. / Wy weten van als te segghene rage: / van dien, van desen, van ghunder, van daer. / Den Daghelicxschen Snaetere Van blyscepe, van druck. / sVolcx Clappage Van licht, van zwaer, / van varre, van naer hebben wy de wete. / Den Daghelicxschen Snaetere Eist openbaer oft int secrete, / wanneer wyt cryghen in den mont, / al de weerelt die weetet terstont. / Dat wy niet en weten, wy wel helen. / sVolcx Clappage Wy en sullen niet verminderen. / Den Daghelicxschen Snaetere Wy en sullen niet stelen. / Wy zouder eer toedoen dander ghebraecke.'
} 
Peace reproduced above, The People's Gossip wants to know from Everyday Chitchat whether the people are saying anything about the recent agreement between Charles V and Francis I. They are saying all sorts of things, the huckster replies: some call it a peace treaty, others a truce. It is hard to draw consistent conclusions about what the public is thinking, however, 'because the opinion of the people / is so unstable and changeable' ('[o]mdat svolcx ghedochte / soo wanckelbaer es ende variabele', 11. 49-50). Some rejoice at the peace, but many get no satisfaction out of it at all. Treaties have so often been concluded and were just as easily broken, they feel. Why would this one last? Moreover, it has been made by mutual consent and not by means of an official contract. Finally, a lot of people are dissatisfied because they have not fully understood the significance of the treaty, despite the fact that an official ordinance has recently been proclaimed from the tower of the Bruges belfry (11. 51-70).

Besides characters that stand for the circulation and commenting on of news among the inhabitants of Bruges, Everaert's plays also contain representatives of the government, who voice the official version of the political events discussed. Thus, the announcement of the Peace of Madrid, brought from Spain by the sailor Consoling Assistance in Willing Labour and People of Commerce, is later confirmed by The Will of the Lord ('sHeeren Wille'), 'dressed in a tunic like a herald, carrying the Emperor's coat of arms'. ${ }^{6}$ When, in Peace, Everyday Chitchat has expressed the mixed feelings of the population concerning the Truce of Nice, New Tidings ('Nyeuwe Tydynghe'), an elegantly clad woman, mounts the stage. She incites People of all Estates ('Volc van Allen Staeten'), a man dressed half as a nobleman and half as an artisan, and Clerical and Secular ('Gheestelic ende Weerlick'), a man dressed half as a clergyman, half as layman, to rejoice in the news that she is bringing and to thank God for it. People of all Estates would first like to know 'the full facts of the meaning of the peace treaty' ('van den toeghanck des pays den rechten keest', 1. 106), however, a request that New Tidings gladly complies with: it is God's grace that has sent them this gift; through the mediation of the Holy Spirit, who governs the hearts of kings, He has brought about the peace that will be talked about for all eternity (11. 106-10).

\footnotetext{
${ }^{6}$ Hüsken, De spelen van Cornelis Everaert, p. 401.
} 
The 'popular' and the 'official' voices often disagree with one another. Incited by New Tidings's announcement of the Truce of Nice, the characters of Peace start to praise the benefits of peace. When they state that it brings quiet and prosperity, however, Everyday Chitchat heavily opposes the claim. Peace has brought her nothing at all so far. She puts herself out all day long and still has to add money out of her own pocket to keep her business running (1l. 161-64). But the most outspoken clash between the two types of characters is to be found in The Uneven Currency, a play dealing with the heavy fluctuation of the currency and its effects on Bruges industry and trade, represented by A Big Part of the Population ('Menichte van Volcke') and The Needy Craftsman ('Den Scaemelen Aerbeyder'). Although not directly apparent from her name, it is clearly Common Sense ('Redelic Ghevoel') who embodies the official stance to the situation. Her religiously inspired calls for endurance are ridiculed by Everyday Chitchat, who overtly criticizes the slowness with which Habsburg authorities deal with the problems. If measures are not taken, uneven currency will ruin both A Big Part of the Population and The Needy Craftsman (1l. 154-57). When Common Sense claims that only endurance can make the currency rise again, Everyday Chitchat wonders aloud whether trying to influence the value of money had not been forbidden by the Emperor (1l. 370-71). Common Sense's reassurance that Charles will fix the monetary problems makes Everyday Chitchat remark that if they are to wait until the Emperor does something about the crisis, they will have to show a lot of patience (1l. 388-93). After Common Sense has reproached A Big Part of the Population for showing more love for earthly goods than for God and thus turning himself into a heretic in the eyes of the Almighty, the huckster concludes that if one were to consider everyone who loves earthly goods more than God a Lutheran, one would find a great number of Lutherans in the world (11. 516-23).

\section{III}

The representation put forward by Everaert's plays of a speedy and busy transmission of intensely debated political news among broad layers of the Bruges population, of the often limited verifiability of the news items and of the endeavours of the central authorities to control their circulation and the opinions people formed on the basis 
of them seems to correspond to a great extent to what the study of chronicles, diaries and court records have made apparent about newsgathering and formation of public opinion in early modern Europe. ${ }^{7}$ What distinguishes the dramatic works of the Bruges playwright from these administrative and narrative sources, however, is their distance and ontological relationship vis-à-vis the situation that they reflect. Unlike in the case of chronicles, diaries and court records, we are not dealing with renderings a posteriori here; Everaert's plays functioned in the middle of the events represented in them. They were generally performed only a few days after the political occasions discussed in the texts. ${ }^{8}$ In other words, they brought to the stage an image of the spreading of and commenting on an item of news at the very moment when that same item of news was being spread and commented on in the streets and squares of Bruges. Therefore, if we want to capture fully the value of these plays as sources for our knowledge of the relationship between literature and early modern newsgathering and public opinion, we should not only ask how they reflected a particular situation but also why they did this. Or to paraphrase the words of A Certain Rhetorician at the beginning of The Uneven Currency once more, in what way did Everyday Chitchat serve the playwright well? What was the author's aim with this character?

In order to get a clearer view of the function of Everaert's allegorizations of popular newsgathering and public opinion we have to consider the actions and interventions of these characters within the larger framework of the spel van zinne (the Dutch version of the morality play), the dramatic genre in which these plays have been composed. Spelen van zinne were a highly conventionalized type of drama. Their aim was to transmit to the audience a $z i n$, i.e. an idea, an opinion or an argument that was generally of a moral nature. At the centre of the spel van zinne are always one or more protagonists that represent humanity as a whole or specific groups therein. These main characters pass through an evolution from a state of sin to a state of grace, from a problem to a solution, from ignorance or confusion to understanding. In this process they are confronted with opponents that try to cross

${ }^{7}$ See, for example, Fox, 'Rumour, News and Popular Political Opinion in Elizabethan and Early Stuart England'; Shagan, 'Rumours and Popular Politics in the Reign of Henry VIII'; Van Nierop, " And Ye Shall Hear of Wars and Rumours of Wars"'.

${ }^{8}$ Hüsken, 'Kroniek van het toneel in Brugge (1468-1556)'. 
them, the so-called sinnekens, ${ }^{9}$ and with advisers that keep them on the right track and from whom they receive help. ${ }^{10}$

Everaert's plays for the celebrations of the Peace of Madrid, for the Peace of Cambrai and the imperial coronation of Charles V and for the Truce of Nice fit neatly within the basic structure of the spel van zinne. Its three distinct types of characters can easily be discerned. Willing Labour and People of Commerce (Willing Labour and People of Commerce), A Big Part of the Population and The Needy Craftsman (The Uneven Currency) and People of all Estates and Clerical and Secular (Peace) are the central human figures, who in this case stand for the Bruges population that was watching these performances. As for the two other types, they clearly set the 'official' and the 'popular' voices in the plays apart from one another. The characters that represent Habsburg discourse, Common Sense in The Uneven Currency, The Will of the Lord in Willing Labour and People of Commerce and New Tidings in Peace, fulfil a distinct advisory function. They patiently lead the protagonists-and through them the spectators that they embody-to a correct understanding of the $z$ in of the plays: the positive effects that are to be expected from the Peace of Madrid and the Truce of Nice, especially for the Bruges' economy, and the divine intervention in the coming about of these agreements in the case of Willing Labour and People of Commerce and Peace, and the need for endurance and charity in trying times in The Uneven Currency. Everyday Chitchat from The Uneven Currency and Everyday Chitchat and The People's Gossip from Peace, on the other hand, show an outspoken resemblance to the sinnekens. Their interventions are generally strongly opposed to those of the advisory characters and the willingness of the central human figures to listen to what they are saying diminishes as the authority of the councillors grows. A turning point, typical of sinnekens-spelen van zinne, is when, under the influence of their adviser(s), the protagonists come to a full understanding of the negative nature of the sinnekens and realize that they have been seduced into evil by them.

${ }^{9}$ On the characters of the sinnekens, see Hummelen, De sinnekens in het Rederijkersdrama. The term sinneken refers to the natural, bodily impulses and desires (Hummelen, De sinnekens in het Rederijkersdrama, p. 32).

${ }_{10}$ The dramatic development of the spel van zinne is discussed in Coigneau, 'Rederijkersliteratuur', p. 45; Spies, “"Op de questye...”', p. 139; Hummelen, 'Het tableau vivant, de "toog", in de toneelspelen van de rederijkers', p. 209; Ramakers, 'Horen en zien, lezen en beleven. Over toogspelen in opvoering en druk', p. 130, and Moser, De strijd voor rhetorica, p. 131. 
'Ward off Everyday Chitchat, who is full of scandalmongering, right away' ('Weert van hulieden, zonder resspyt, / den Daghelicxschen Snaeter vulder blamacien', 11. 598-99), Common Sense calls on A Big Part of the Population in The Uneven Currency, after which the latter addresses Everyday Chitchat in terms that clearly indicate his conversion and his realization of the negative influence of the huckster:

Everyday Chitchat, leave this place immediately.

I regret ever having associated with you

or ever having chattered

about any prince, city or land..$^{11}(11.604-07)$

Through the conventions of the spel van zinne-with which, as the substantial number of plays of this type that have come down to us suggest, the public was well acquainted-characters such as Everyday Chitchat and The People's Gossip were clearly marked as negative examples not to be followed. Like the protagonists that represented them on the stage, the spectators were to turn away from people that spread rumours about the princes or about political events or that talked about the state of the land and of its leaders in an overtly critical way. Instead, they were to confide in the information and the guidance that the government provided them with and rejoice in the event that was being celebrated.

Everaert's use of allegorical characters representing the circulation of political news and the formation of public opinion thus served a propagandistic purpose. Through a dramatic allegorical rendering of the world of the spectators, the author demonstrated to his audience how to deal with the heterogeneous stream of information and opinions that circulated about the Habsburg princes and their policy. This kind of political-propagandistic use of the performance of literary texts, especially of song and of serious drama, was highly common in the late medieval and early modern Low Countries. Both genres were primarily oral and highly popular among broad layers of the population. They could therefore be used to transmit messages to large groups of people simultaneously and, because of the direct contact between performers and audience, in a more controlled manner than anonymously distributed written texts. By the middle of the sixteenth

11 'Den Daghelicxschen Snaeter, maect hu van hier schier. / My es leedt, dat ic oynt an hu verselde / of dat ic my oynt om clappene stelde / van eeneghe princhen, steden of landen.' Cf. Pays, 1l. 276-85. 
century songs had been used in the Low Countries to inform people of politically related events for at least 350 years. ${ }^{12}$ The spel van zinne of the rhetoricians, on the other hand, was a highly didactic genre that had originally been primarily religious-moralistic in theme, but the political-propagandistic possibilities of which seem to have been gradually discovered and developed by rhetoricians and city authorities in the course of the fifteenth century. ${ }^{13}$ The number of plays and songs of this type that have come down to us is relatively limited, but references in chronicles and urban accounts to the performance of lost texts that have been presented in a similar context indicate that they must have been very common, especially during the kind of urban public celebration for which Everaert wrote his political drama. ${ }^{14}$

The use of plays and poems to influence public opinion was obviously not restricted to those in power. Their opponents could just as easily employ them. Conflicts between the prince and groups or individuals outside or within the state were not only fought on the battlefield and within the legal system but also in the streets and the squares, where texts in favour of or against the monarch were performed, and especially in the minds and the opinions of the people at whom these literary products were aimed. In the course of his long series of wars with the Burgundian Duke Charles the Bold, the French king Louis XI had, according to the Excellente Cronike van Vlaenderen, 'songs sung and plays performed against Duke Charles' ( 'liedekens singhen ende speilkins spelen contrarie den Hertoghe Kaerle'). ${ }^{15}$ In 1514 a

12 The oldest historical song in Van de Graft, Middelnederlandsche historieliederen, pp. 43-44, dates from 1173.

${ }_{13}$ Mareel, Voor vorst en stad, pp. 27-32.

${ }^{14}$ For a discussion of the texts that have come down to us as well as references to the performance of lost plays and songs, see Mareel, Voor vorst en stad. The popularity of political songs and the often highly contested veracity of their content is also apparent from an interesting poem in the manuscript collection compiled by the Utrecht canon and vicar Jan van Stijevoort in 1524. In the poem the author rages against singers who perform and sell political songs in public: 'Ist datse connen cluijten versieren / Van princhen heren coninghen graven / Sy soecken grote list ende nouwe manieren / Om liedekens te maken om sgelts vertieren / Daer sy int gasthuys haer kelen met laven / Sy doent tvolc mitten mont te deghen draven / Ende mitten ganghe weten sij min dan niet' ('Whenever they can, they make up stories about princes, lords, kings and dukes. They sharpen their ingenuity and set about making songs for money, with which they quench their thirst in their lodging. They give the people a lot to talk about, but about the true nature of events they know nothing.') (Komrij, De Nederlandse poezie van de twaalfde tot en met de zestiende eeuw, pp. 689-91).

${ }_{15}$ Dits die excellente cronike van Vlaenderen. Antwerp: Willem Vorsterman, 1531, fol. C.lix.r. 
proclamation was issued in Antwerp forbidding anyone 'to make, recite or sing songs, poems and the like taunting, disdaining or insulting any king, monarch, prince or other important lord'. ${ }^{16} \mathrm{~A}$ number of pro-Habsburg songs that have come down to us and that were written around the year 1543, during one of the many military conflicts between Charles V and Francis I, explicitly deny the report spread by the enemy that Charles had drowned, 'that the codfish had eaten him'. ${ }^{17}$ The texts do not mention how this rumour had been put about, but it is not unlikely that the French had used the same medium as did the Habsburgs for the denial.

What makes the Everaert plays under discussion interesting and unique compared to these other propagandistic literary texts is the fact that, through their allegorization of the very process of newsspreading and formation of public opinion, they not only give us insight into the messages that were transmitted but also into the way in which these were received and discussed. Messages were not sent out at random, but had to interact with pre-existing beliefs and opinions among the spectators. These plays confirm what Henk van Nierop suggested with regard to the function of rumour during the Dutch Revolt, namely that it did not constitute an alternative circuit of information for the powerless, for those that were cut off from governmentcontrolled information, as certain historians have thought. Instead, both sources interacted intensely with one another. ${ }^{18}$ As the interventions of Consoling Assistance and The Will of the Lord in Willing Labour and People of Commerce and Everyday Chitchat and The People's Gossip in Peace indicate, official versions of the celebrated events often arrived later than the unofficial ones, which they had to confirm or refute. The theatrical glorification of the Truce of Nice, Peace shows us, had to take into account the fact that a great number of previous agreements of this kind had not lasted, causing growing disbelief among the population as to their effectiveness. ${ }^{19}$ Moreover, as Everyday Chitchat in The Uneven Currency suggests, news about Habsburg policy was interpreted against the background of a general

\footnotetext{
16 'Liedekens, gedichten en diergelyke [...] te maken, te spreken of te singen in schimpe, cleynigheyden of versmadenissen van eenige Koningen, Vorsten, Princen oft andere groote Heeren'. Joldersma, 'Het Antwerps liedboek', pp. XLVIII-XLIX.

17 '[d] at hem die cabbeliauwen hadden eyn'; Van de Graft, Middelnederlandsche historieliederen, p. 229; cf. pp. 233, 237.

${ }_{18}$ Van Nierop, “"And Ye Shall Hear of Wars and Rumours of Wars”', p. 73.

19 Pays, 11. 41-60.
} 
dissatisfaction about the slowness with which the government dealt with economic and social problems. ${ }^{20}$

Although Everaert's allegorizations of popular newsmongering and formation of public opinion are clearly related to the sinnekens, somehow this garment does not completely fit Everyday Chitchat and The People's Gossip. ${ }^{21}$ The nature of the traditional sinnekens was outspokenly amoral, even demonic, their aim being to seduce the central human figure into sin and thus bring about his damnation. ${ }^{22}$ From the outset of the play, the spectators could easily recognize them as such. However, it remains to be seen to what degree this was also the case with the rumour and news-spreading characters in The Uneven Currency and in Peace. E. Shagan defined rumour as 'unofficial or improvised news, whose claim to legitimacy depends more upon the resonance of its content than upon the reliability of its source' ${ }^{23}$ When we broaden this definition to pertain to the circulation of not only rumour but also opinions and apply it to the interventions of Everyday Chitchat and The People's Gossip, these characters take on quite different connotations than their traditional sinnekens counterparts. The plays in which they appear were performed during a period of latent dissatisfaction with Habsburg policy, caused by an economic and social crisis that was seriously aggravated by the Italian Wars of Charles V. ${ }^{24}$ Whether well-founded or not, the remarks of Everyday Chitchat and The People's Gossip about the unwillingness or inability of Habsburg authorities to deal with the situation, about the inappropriateness of their repeated religiously inspired appeals to patience and perseverance and about the inconstancy and lack of effectiveness of the peace treaties in which they engaged must have resonated strongly among the spectators in this context and, according to Shagan's definition, make a considerable claim to legitimacy.

\footnotetext{
${ }^{20}$ dOnghelycke Munte, 11. 392-93.

${ }^{21}$ Hummelen apparently did not consider them to have enough typical characteristics of the sinnekens to mention them in his study.

${ }^{22}$ Hummelen, De sinnekens in het Rederijkersdrama, especially pp. 34-40; cf. Coigneau, 'Rederijkersliteratuur', p. 45.

${ }^{23}$ Shagan, 'Rumours and Popular Politics', p. 36.

${ }^{24}$ Cf. note 2.
} 
When we focus on what Everyday Chitchat and The People's Gossip are actually saying rather than on the way in which their behaviour dovetails with the conventions of the spel van zinne, they show more similarities with another character type from late medieval Dutch drama culture, namely that of the nar or fool. Pleij characterized the fool as an intangible outsider who tells the truth. ${ }^{25}$ Both aspects of this definition are highly revelatory as to the nature and function of Everyday Chitchat and The People's Gossip. As a petty retailer selling goods from door to door and in the streets, Everyday Chitchat was obviously well placed to pick up gossip and bits of news and pass them on. At the same time, however, women who practiced this trade-for in real life as in Everaert's plays they were usually women-were also people on the fringe of society, recent immigrants who were too poor to rent a stall in the market or find some other kind of job that required relations and/or starting capital. ${ }^{26}$ Like the more traditional fool, they were marginal figures that were generally not taken seriously and were therefore able to possess a virtually limitless freedom of speech. ${ }^{27}$ They supposedly used this liberty to voice 'the truth', a central element in the concept of the fool. In his Praise of Folly, Erasmus considered fools 'the only ones who speak frankly and tell the truth', wondering at the same time 'what is more praiseworthy than truth?'. ${ }^{28}$ After he has been chased from the stage by the central human figures and their allegorical counsellor, The People's Gossip exclaims in Peace that 'he who tells the truth isn't welcome anywhere' ('[d] ie de waerheyt seght en es nyeuwers ghesien', 1. 286), thus emphasizing before the audience his marginal fool-like character.

The foolish nature of Everaert's allegorizations of the distribution of news, gossip and political comments lends outspoken positive connotations to the practices that these characters stand for. They are presented as channels allowing the utterance of 'truths' that could not be distributed in another way. This association was not uncommon in early modern Dutch drama. Comparable characters can be found in at least two other plays from the period. Van Nyeuvont, Loosheit

\footnotetext{
${ }_{25}$ Pleij, Het gevleugelde woord, p. 649.

${ }^{26}$ On the huckster, see McRee and Dent, 'Working Women in the Medieval City', pp. 245-46.

${ }^{27}$ Cf. Pleij, Het gevleugelde woord, pp. 434, 647.

${ }^{28}$ Quoted in Otto, Fools are Everywhere, p. 96. Otto devotes an entire chapter of her book to this characteristic of the fool (Otto, Fools are Everywhere, pp. 96-131).
} 
ende Practike (Of Shrewd Invention, Slyness and Cunning) was printed between 1497 and 1501 and deals with human love for luxury. ${ }^{29}$ This vice is denounced by Glamor ('Schoontooch'), who is assisted by a marot, a bauble, the traditional attribute of the fool, called Backbiter Telling Truths ('Quaet en Waerseggen'). Charon de Helsche Schippere (Charon, Hell's Skipper), a play from 1551 based on Lucian's dialogue Charon, or the Inspectors, contains a fool called Newsmonger ('Nieuloop'), who rides the hobbyhorse Gossip ('Clappage'). ${ }^{30}$ As in Of Shrewd Invention, Slyness and Cunning, it is through these two characters that the zin of the play, in this case the transience of all earthly glory, is conveyed to the audience.

The critical nature of the interventions of Everyday Chitchat and The People's Gossip is confirmed by a marginal note that Everaert added to his autograph copy of The Uneven Currency. In it, the author mentions that the performance of his play has been forbidden. We know from extant Bruges municipal ordinances announcing theatre competitions that the city fathers tried to control the content of the plays by demanding participants hand in a copy of the text they wanted to stage in advance. ${ }^{31}$ It was probably at that moment that the performance of Everaert's play was blocked. In his explanatory note the playwright links the reason for the ban to one of the main characteristics of the fool. In terms that seem to foreshadow the final speech of The People's Gossip in Peace, he states that the text could not be performed 'because truth had not been withheld' ('omdat de waerheyt niet was gheheilt'). ${ }^{32}$

How, then, are we to reconcile the sinnekens and the fool-function of Everyday Chitchat and The People's Gossip? Did these characters serve the author in glorifying Habsburg authority or rather in denouncing its slowness and inefficiency? Considering the fact that Everaert endorsed the 'truth' in the outspoken critique uttered by the apple and

\footnotetext{
${ }^{29}$ Neurdenberg, Van Nyeuvont, Loosheit ende Practike; cf. Hüsken, 'The Fool as Social Critic'.

${ }^{30}$ De Vreese, 'Een spel van Charon de helsche schippere'; cf. Hüsken, 'The Fool as Social Critic', pp. 133-35 and Pleij, Het gevleugelde woord, pp. 458-59.

${ }^{31}$ References to literary activities in the Bruges municipal ordinances have been edited, discussed and translated in English in Hüsken, 'Politics and Drama: The City of Bruges as Organizer of Drama Festivals'.

${ }^{32}$ Hüsken, De Spelen van Cornelis Everaert, p. 526. The author made a comparable remark in the margin of Crych, a play that was also banned (Hüsken, De Spelen van Cornelis Everaert, p. 437).
} 
hazelnut vendors and by the workman, it might seem as if the conventions of the spel van zinne have only been respected to get the plays through the preliminary inspection, as if the glorification and marks of loyalty towards central authority constituted nothing more than a thin sweet veil hiding bitter invective. The real stance of the plays, and of their author, towards the sociopolitical issues discussed seems to be more subtle and complex, however. A key passage for a correct understanding of these texts is made up by $11.272-77$ of The Uneven Currency, in which A Certain Rhetorician, after Common Sense has reproached him for not entertaining A Big Part of the Population on the occasion of the imperial coronation of Charles V, remarks:

At the time of the victory I had done my duty.

When peace was announced I had given myself entirely

In honour of my Emperor, whom I love as I love God,

I have shown my skills.

[...]

Too much of the same thing does not give satisfaction, however. ${ }^{33}$

This passage is uttered by A Certain Rhetorician, who, as noted above, seems to share Everaert's own fondness of the news and opinions that circulated on the streets as dramatic material. There is some evidence that will allow us to carry even further the identification of A Certain Rhetorician with the Bruges playwright; it is very likely that the role of A Certain Rhetorician was performed by the author himself. Everaert's first editors, J.W. Muller and L. Scharpé, have drawn attention to several passages in his plays that indicate that he not only wrote the texts but also acted in them. ${ }^{34}$ But even if A Certain Rhetorician was not impersonated by Everaert, the spectators will surely have interpreted the first lines of the passage as a reference to the three highly laudative plays that Everaert wrote a few years earlier for theatre competitions on the occasion of the victory of Habsburg troops over French troops near the Italian town of Pavia in 1525 and the ensuing Peace of Madrid of $1526 .{ }^{35}$ As both the evolution of these earlier political plays into

33 'In den tyt der victorien ic myn devoor ghedaen hebbe. / In de tydynghe van payse en hebbic niet ghespaert / Ter eeren myns skeysers thoochdic mynen aert, / die my naest Gode es liefghetal. / [...] / Te vele van een en es gheen becomte.'

${ }_{34}$ Muller and Scharpé, Spelen van Cornelis Everaert, p. 604.

${ }^{35}$ High Wind and Sweet Rain (Hooghen Wynt ende Zoeten Reyn) and Aragonese (Aragoenoysen) for the victory near Pavia and Willing Labour and People of Commerce (Ghewillich Labuer ende Volc van Neerrynghe) for the Peace of Madrid; see Hüsken, De Spelen van Cornelis Everaert, pp. 219-49, 274-99 and 386-413. 
the more critical later dramatic texts discussed in the present article and the lines quoted above suggest, Cornelis Everaert seems to have felt a growing disappointment at the slowness and ineffectiveness of Habsburg policy, the consequences of which, as a dyer and fuller in the cloth industry of his hometown, he must have experienced personally. Like A Certain Rhetorician in The Uneven Currency, he seems to have used his theatre as a means to express this disappointment.

In Willing Labour and People of Commerce, The Uneven Currency and Peace, Cornelis Everaert left us fascinating examples of both the function of popular newsgathering and formation of public opinion in the literary text and of the function of the literary text in the process of popular newsgathering and formation of public opinion. As allegorizations of practices that were at the same time perceived as reprehensible and as allowing the expression of 'truths' that could not circulate in another way, characters such as Everyday Chitchat and The People's Gossip concurrently represented and voiced Everaert's double feeling of love and loyalty towards the Emperor on the one hand and his disappointment at the slowness and ineffectiveness of the monarch's policy on the other. However, as public performances, these texts were also agents in the very process of newsgathering and formation of public opinion that they visualized-something of which the author, we may assume, was well aware. Because of the ambiguous nature-related to both the sinnekens and the fool-of Everyday Chitchat and The People's Gossip, the plays actually reinforced the messages they were supposed to, and at a superficial level also seemed to, suppress.

In a broader perspective, these compositions show both the advantages and disadvantages of the use of popular drama as a means to control the circulation of news and gossip and influence public opinion. Everaert wrote two, possibly all three of the plays for theatre competitions during public festivals in honour of the princes. One of the aims of these events was to direct political gossip, informal newsgathering and formation of public opinion along pro-Habsburg lines. Because of its didactic nature and typical techniques such as audience representation and allegorization of abstract notions, the spel van zinne of the rhetoricians lent itself particularly well to this kind of political 
propaganda. Moreover, the genre was very popular, providing a wide and enthusiastic audience, and its authors belonged to the social groups at which the texts were aimed, and were thus well aware of its opinions, ideas and sensibilities. However, the use of popular drama in this way was a two-edged sword. As a member of the community that harboured the rumours and opinions the authorities wanted to alter, a playwright such as Cornelis Everaert was equally affected by the circumstances that had given rise to these rumours and opinions. He might therefore use the privileged position on the public forum that the stage granted him to express not only his loyalty but also his dissatisfaction. As a skilled rhetorician, by slightly subverting the conventions of the spel van zinne he subverted the political message of his text as well, turning a genre with high propagandistic potential into a medium for the very opposite. The allegorical representations of informal newsgathering, gossip and public opinion thus became as intangible as the phenomena they stood for. 



\title{
'PLEASE DO NOT MIND THE CRUDENESS OF ITS WEAVE': LITERATURE, GENDER AND THE POLEMIC AUTHORITY OF ANNA BIJNS
}

\author{
Judith Keßler
}

When Martin Luther caused a commotion in the Catholic world in 1517 with his 95 theses against the selling of indulgences and the authority of the Pope, the Church quickly and firmly reacted in a variety of ways. Lutheran books and writings were censored, scholarly books in Latin argued against the heretical doctrines of the Augustine monk and the new doctrine was attacked from the pulpit. Apart from these strategies of defence, in the Low Countries another weapon in the war against Luther was wielded which was highly unusual: the writings of a laywoman. More precisely, this laywoman was made-and made herself-the mouthpiece of the small but very successful centre of resistance in Antwerp that was created by the Franciscans, or Minorites. Instead of writing or preaching themselves (or, at least, in addition to that), they powerfully supported this single person in her own personal campaign against Luther by compiling her works more than once and presumably also by publishing these compilations. The name of the poetess who seems to have impressed the Franciscans with her poems was Anna Bijns. ${ }^{1}$ Born and bred in Antwerp and brought up in a traditional Catholic way, she could in no way agree with Luther's vision of the content of the Christian faith without devotion to Mary, without honouring all the sacraments and without obedience to the Pope. As one of the first of Luther's adversaries in Dutch, she responded to his ideas with sharp attacks in the vernacular.

Even though we are currently familiar with a long medieval tradition of influential women and female authors who were hermits and

\footnotetext{
${ }^{1}$ Her biography by Van den Branden (Anna Bijns) dates from 1911. The most important monograph about her works, also reacting to earlier research, is Roose, Anna Bijns, published in 1963. Results of recent research can be found in Pleij, Het gevleugelde woord (2007).
} 
Beguines, ${ }^{2}$ it seems astonishing that one of the first printed polemics against Luther in the Netherlands was written by a laywoman, especially when we consider the fact that this woman did not speak just for herself, but in the name of a larger group of the faithful. This contribution will therefore investigate how and why Anna Bijns could become their mouthpiece. What role did the Franciscans play? How could she, a female author, acquire such standing that members of a monastic order supported her and that her readers accepted her authority, as becomes apparent from the large number of reprints of her books continuing well into the seventeenth century $?^{3}$ As a part of my investigations, I will look at her self-presentation and at the extent to which this self-presentation affected her reception. I also will discuss the part the printing of her poems played in the distribution of her ideas and the consolidation of her fame. The fact that the Franciscans were involved raises interesting questions about their joint struggle against Luther: why would the Franciscans raise a laywoman to the level of their most visible spokesperson in the public polemics against the Lutherans? It still seems striking that the members of the Antwerp order did not choose a male author, perhaps one of their own community, to defend the Catholic cause, but instead a laywoman who was not learned, who was not a member of a religious order and who was not a Beguine.

\section{Method AND SOURCES}

There are three printed poetry collections (1528, circa 1548 and 1567) $)^{4}$ from which we can infer something about the (self-)presentation of Anna Bijns as an authority in the public debates about Luther. I have chosen to concentrate on the three printed compilations rather than

\footnotetext{
${ }^{2}$ For the Netherlands, one could think of the mystical authors Beatrijs of Nazareth or Hadewijch. On mystical female literature see Beer, Women and Mystical Experience in the Middle Ages. Specifically for Beatrijs of Nazareth see Huls, Seuen manieren van minnen; for Hadewijch see the series by Willaert and Fraters, Hadewijchs verzameld werk; still important is also Willaert, De poëtica van Hadewijch.

${ }^{3}$ All her collections published in the sixteenth century were reprinted well into the seventeenth century; the first edition dates from 1528, the last from 1668 . See also Roose, Anna Bijns, pp. 53-70. Moreover, there are manuscripts-see n. 4.

${ }^{4}$ The collections are available online: Keßler and Oosterman, Schoon ende suverlijc boecxken (first collection), Keßler and Oosterman, Tweede boeck vol schoone ende constighe refereynen (second collection), and Keßler and Oosterman, Seer scoon ende suyver boeck (third collection).
} 
on the extant manuscripts. The printing press could, after all, reach many more readers than manuscripts could, whereas a (self-)presentation can only be successful when disseminated amongst as many people as possible.

The crucial information is contained not in the main text of the poems collected in these three books, but in the 'paratexts': it is hidden in the title, the preface, the epilogue and any other text not included in the poems themselves. ${ }^{5}$ In these paratexts, Bijns or the compiler of the book explain to the reader why certain poems were chosen and what the overall purpose of the collection was. This might show how, and by whom, Bijns was made into an authority with regard to such a highly sensitive theological matter as the struggle against Luther. An analysis of the paratexts, which carefully distinguishes the various authors and their purposes, appears to be an auspicious approach in order to detect the strategies of (self-)presentation used by Anna Bijns and the compilers of her books.

However, before we analyse the paratexts, we first need a better understanding of Anna Bijns's biography and the literary, social and intellectual context in which she lived and worked-notably that of the chambers of rhetoric. Greater understanding of the organization of the three printed collections and the genres of the poems will help to determine what the paratexts reveal about Bijns's polemical role.

\section{ANNA Bijns, RHETORICIANS AND REFRAINS}

Anna Bijns (1493-1575) lived in Antwerp where she worked as a teacher. She never married and she lived alone, not as a nun and not as a Beguine. To live this way was quite unusual for a woman in this

${ }^{5}$ For a definition of paratexts see Genette, Paratexts, esp. pp. 1-2. I use the term in the general sense, comprising also peritexts. It is not implied that no paratexts (as important instruments for self-fashioning) are contained in the manuscripts. For instance, in the large compilation of manuscript B (signature Ghent, UB, 2166) with its 112 poems, many are dated, so this is an important clue to the period in which Bijns was writing. According to the dates given there, the poems in the manuscript were written between 1523 and 1529. Manuscript A (signature Brussels, KB, 19547), a compilation of about 60 poems made by Bijns and many poems from other authors, also has some paratexts, e.g. an extensive table of contents. But in both cases (and these are the most important, because they are the most voluminous, manuscript compilations of Bijns's works), the paratexts do not convey anything about the intentions of the (author of the) poems and/or the compilations. They were not meant to be read by many people and remained rather inaccessible. 
period, because she did not have the protection and safety of a religious community. ${ }^{6}$ Bijns earned her own living, working in her own small school until the age of 80 . $^{7}$

As a deeply devout Christian, she was interested in the recent developments in religious affairs. Because of her commitment to these issues she was informed of Martin Luther's new ideas at an early stage. She must have known about him as early as 1519, when a monk from Ypres called Jacobus Praepositus-a friend of Luther's and, just like him, a member of the Augustinian order-came to Antwerp to preach Luther's teachings. ${ }^{8}$ It is possible that from what she heard at the convent of the Franciscans-with whom she maintained close contact ${ }^{9}-$ she developed her own highly critical opinions of Luther. She seems to have been absolutely convinced that Catholic doctrine alone can guide man to heaven; in her opinion, ${ }^{10}$ Luther's doctrine plotted a path

${ }^{6}$ Unfortunately, not much is known about her life. The only biography is written by the Antwerp archivist Van den Branden in 1911 and much of what he tells us is a romantic glorification. His account indeed is based on facts found in the Antwerp archives, but it is sometimes difficult to see what is fact and what is mystification. Van den Branden does not know about the reasons why she stayed unmarried. He believes that she first had to help her mother in housekeeping for the family (one younger brother, Meerten, and one younger sister, Margriete) after her father's death, and after mother's death she took her place. Later on, he assumes, she might have had prejudices against marriage, see Van den Branden, Anna Bijns, pp. 68-69. For more information on Bijns and her works see also Pleij, Het gevleugelde woord, pp. 370-91. A short overview about her life, works and her way of responding to the threat of Luther and his teachings is given by Pollmann, "Each Should Tend his Own Garden"'.

${ }^{7}$ From 1536 on she was a member of the St. Ambrosius guild for teachers, see Van den Branden, Anna Bijns, p. 63. According to Van den Branden she asked only 26 'stuivers' per pupil per year. He calculated that she, with 40 pupils, earned about 52 'gulden' per year-a small sum (ibidem, pp. 85-86).

8 On Praepositus: Bautz, Biographisch-bibliographisches Kirchenlexikon, vol. 7, cols. 966-68; Roose, Anna Bijns, pp. 6-10; Visser, Luther's geschriften in de Nederlanden tot 1546, pp. 153-56.

9 This is known through the large number of acrostics in her poems; she used them to dedicate the refrains to her friends. Most of them are about a man called 'Bonaventura' who is thought to be Bonaventura Vorsel, her confessor and a member of the Antwerp Franciscan order (on him see: Julius, 'Anna Bijns en Bonaventura'), but there are also other acrostics. All of them are the reflections of close amicable connections between Bijns and her friends. See: Pleij, 'Anna Bijns als pamflettiste', and Keßler, 'Wie is Cornelis Damasz?'.

${ }^{10}$ See about the difference between the opinion of a real person and the opinion the reader can extract from a written text the standard works of Barthes ('The Death of the Author'), Foucault ('What is an author?'; I used the Dutch translation under the title 'Wat is een auteur?') and Booth (The Rhetoric of Fiction). For the application of their theories about opinions of several readers from the past on Bijns; see Keßler, 'Anna in veelvoud'. 
straight to hell. Her objections to Luther prompted her to write against him in particular. But even though she also wrote about many other topics (such as her devotion to Mary or Christ, or her derisive view of marriage), the poems in which she sharply attacked the Reformer were the ones that created her fame as the great female opponent of Luther in the Low Countries.

When Bijns wrote against Luther, she always used the form of the refrein ('refrain'), a popular genre between the fifteenth and the early seventeenth century. ${ }^{11}$ This variant of the French ballad consists of at least four stanzas and employs an intricate rhyme scheme. The last line of a stanza (stokregel) is repeated at the end of each stanza and has the character of a maxim; for that reason, the stokregel is often used as the refrain's title. The last stanza routinely addresses a non-specific 'prince'. This can be the prince (president) of a chamber of rhetoric or, in religious refrains, it can also be God or Christ. ${ }^{12}$

The refrains were one of the quintessential forms of the rhetoricians ('rederijkers'). Rhetoricians assembled in the chambers of rhetoric ('rederijkerskamers'), which were the influential literary institutions, organized in cities, towns and villages of the most urbanized regions of the late medieval and early modern Low Countries. Within the context of chamber meetings, rhetorician contests and local festive culture, rhetoricians (mainly from the middle groups of society, often including individual priests and teachers) produced literary texts for private and public performance, mainly (and most regularly) refrains and songs, but also plays. ${ }^{13}$

The rhetoricians organized interlocal festive contests where the participating chambers performed plays, songs, and refrains as an answer to a predetermined prize question. ${ }^{14}$ Rhetoricians' plays and poems

${ }^{11}$ There is only one exception: Oosterman recovered a song that must have been written by her (manuscript Leiden, UB, BPL 1289): (Oosterman, 'Jenneken Verelst en Anna Bijns'). The song is also extant in manuscript Utrecht, BMH, 111.

${ }_{12}$ For a good definition see also Coigneau, Refreinen in het zotte bij de rederijkers, vol. 1, pp. 9-13. A contemporary of Bijns, Matthijs de Castelein, wrote, in 1555, the only known rhetoricians poetics: the Const van Rethoriken. A facsimile was published in 1986.

${ }^{13}$ See for recent research into rhetoricians and their chambers: Pleij, Het gevleugelde woord; Van Bruaene, Om beters wille, and Van Dixhoorn, Lustige geesten.

${ }^{14}$ To get an idea of these competitions: Strietman, 'The drama of the rhetoricians in the Low Countries', Ramakers, Op de Hollandse Parnas, or Oosterman and Ramakers, Kamers, kunst en competitie. On the way rhetoricians probed public opinion: Hollaar, Van weelde en andere plagen and idem, De Rotterdamse spelen van 1561. 
must always be read with this highly performative and competitive culture in mind. The allegorical plays were argumentative, and often discussed the pros and cons of an answer to a prize question. The refrains were composed in the same culture of debate, often for competitions that called for refrains on a prize question. This argumentative aspect of rhetoricians' literature was ever present, and so it was in Bijns's refrains. Her refrains can be characterized as poems stating and defending opinions, and in some cases she explicitly states that a refrain is meant as a reaction to another refrain. Bijns's refrains (as a genre) are therefore embedded in a culture of argumentation and persuasion with a strong focus on competition and polemic texts. All texts belonging to that culture are created in highly intricate literary forms. In short, this was the ideal environment for the talented young poet Anna Bijns to hone her poetic skills.

As far as we know, Bijns was never a member of a chamber of rhetoric, since chambers were on the whole exclusively male. Yet she must have been very familiar with this culture since, according to Herman Pleij, Bijns was raised in rhetorician circles. Her father was likely the author of one refrain, and as early as 1512, Anna Bijns is supposed to have won a prize at a rhetoricians contest (although this cannot be proven conclusively). ${ }^{15}$ In any case, it is safe to say that she wrote her first dateable refrain in 1522 , when she was $29 .{ }^{16}$

More than 200 refrains are extant. Her first and second printed collections each contain 23 refrains, the third has 70 refrains. There are also two extensive collections in manuscript ms B (signature Ghent, UB, 2166) with 112 refrains and ms A (signature Brussels, KB, 19547) with 62 refrains. Some of those in manuscript are extant in printed form as well: the number of about 200 refrains applies only to those accessible in a single copy. The latest dateable poem must have been written about $1543-1545,{ }^{17}$ but most of the refrains were made in

${ }^{15}$ See Pleij, Het gevleugelde woord, p. 372 and Pleij, '1512: Antwerpse maagd wint aanmoedigingsprijs'. Van den Branden mentions that she began writing only in 1517, but without saying more about his sources than a vague 'volgens getuigenis van een harer geleerde geestelijke tijdgenoten' ('according to the testimony of one of her learned clergyman contemporaries'); Van den Branden, Anna Bijns, p. 12.

${ }^{16}$ This refrain, 'Tprijst al den rumen wech weert man of wijf is' ('They praise the wide road, whether they are man or woman'), was published in her first collection of 1528 (see Roose, Anna Bijns, p. 210). It is also transmitted in manuscript A where it is dated 'Vijfthienhondert [...] tweentwintich jaer' ('fifteen hundred twenty-two years').

${ }^{17}$ It is the refrain 'Noch schijndt Merten van Rossom de beste van tween' ('Then Maarten of Rossum seems to be the best of the two'), a comparison between the 
the years 1520 to 1530 . This becomes apparent from manuscript B: the refrains contained in this collection are dated between 1523 and 1529 (see ills. 1 and 2). Although the last compilation was published in 1567, all of her refrains were written much earlier. This explains why she only writes against Luther and does not include Calvin in her attacks, although the latter became increasingly influential in the Low Countries after 1555. The fact that Calvin is not mentioned suggests that Bijns had stopped writing before his doctrine arrived in the Low Countries.

\section{The COLLECTIONS}

As mentioned, there are two collections in manuscript, mss A and B, and three in printed form. ${ }^{18}$ I will focus only on the printed editions, which were part of an exceptional publishing project initiated by a Franciscan network in Brabant and Flanders.

The first collection was printed by Jacob van Liesvelt of Antwerp in 1528. All the refrains were written by Bijns, and all of them are vehemently anti-Lutheran. ${ }^{19}$ The title indicates what readers could expect to find in this book:

dreaded commander Rossum and Martin Luther, whereby Luther at the end is judged to be worse, because Rossum only kills the bodies of the people, whereas Luther kills their souls. The metaphor is obviously inspired by Matthew 10:28: 'Do not be afraid of those who kill the body but cannot kill the soul. Rather, be afraid of the One who can destroy both soul and body in hell'. The refrain is to be found in manuscript A and must have been written after Rossums siege of Antwerp in 1542.

${ }_{18}$ Apart from these large collections there are also some manuscripts handed down in which only a few refrains are copied (for a survey of these manuscripts see Roose, Anna Bijns, pp. 71-138; for the printed collections see idem, pp. 53-70). The earliest of them is manuscript collection Brussels, KB, II 270 which contains six refrains from ca. 1527 also extant in manuscript B. All the collections containing a small number of refrains do not include new refrains. A late but special case is manuscript A (Brussels, KB, 19547), written in about 1545 . It contains many refrains by Bijns (most of them already handed down in manuscript B) and also many works by other authors. In the case of some of the poems the author cannot be identified. Only the poems handed down in other collections are claimed to be by Bijns (see Roose, Anna Bijns, pp. 85-118). It is therefore possible that Bijns wrote some more of the refrains contained there, but this is difficult to prove by lack of an acrostic or her signature. Both manuscripts, A and B, are supposed to have been made by the Antwerpian Franciscan Enghelbrecht vander Donck (on this see Roose, Anna Bijns, pp. 71-72). They both contain refrains with a diversity of subjects, from anti-Lutheran to jesting, from intensely devotional to comic.

${ }^{19}$ For a detailed analysis of this and the other printed collection of Bijns, I refer to my dissertation (forthcoming 2011). 


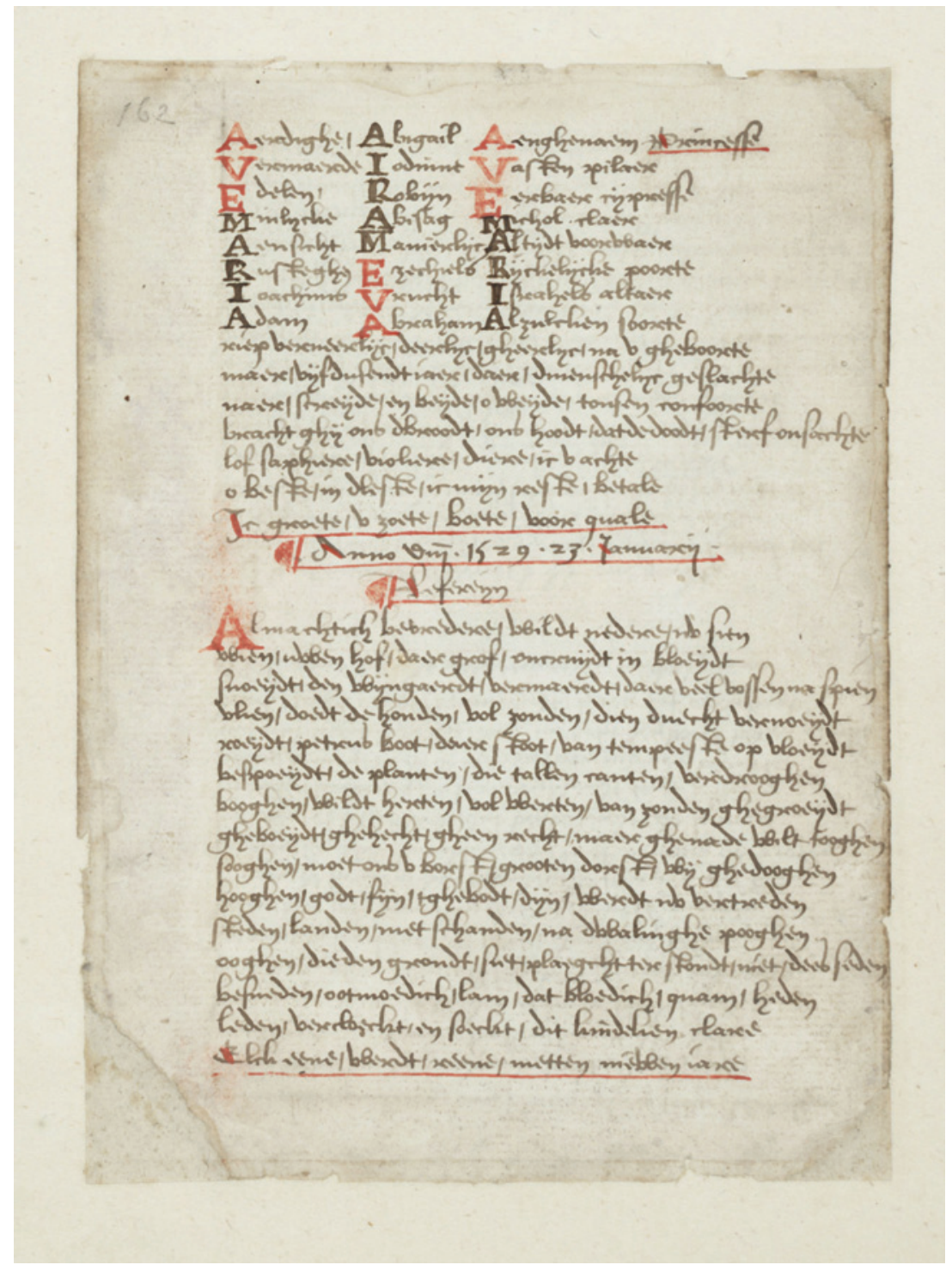

Ill. 1. MS Ghent 2166, fol. 162r. The refrain 'Ic groete u zoete boete voor quale' ('I greet you, sweet recompense for pain'), praising the virgin Mary (as can be seen in the three acrostics AVE MARIA), is dated January 23th, 1529. 


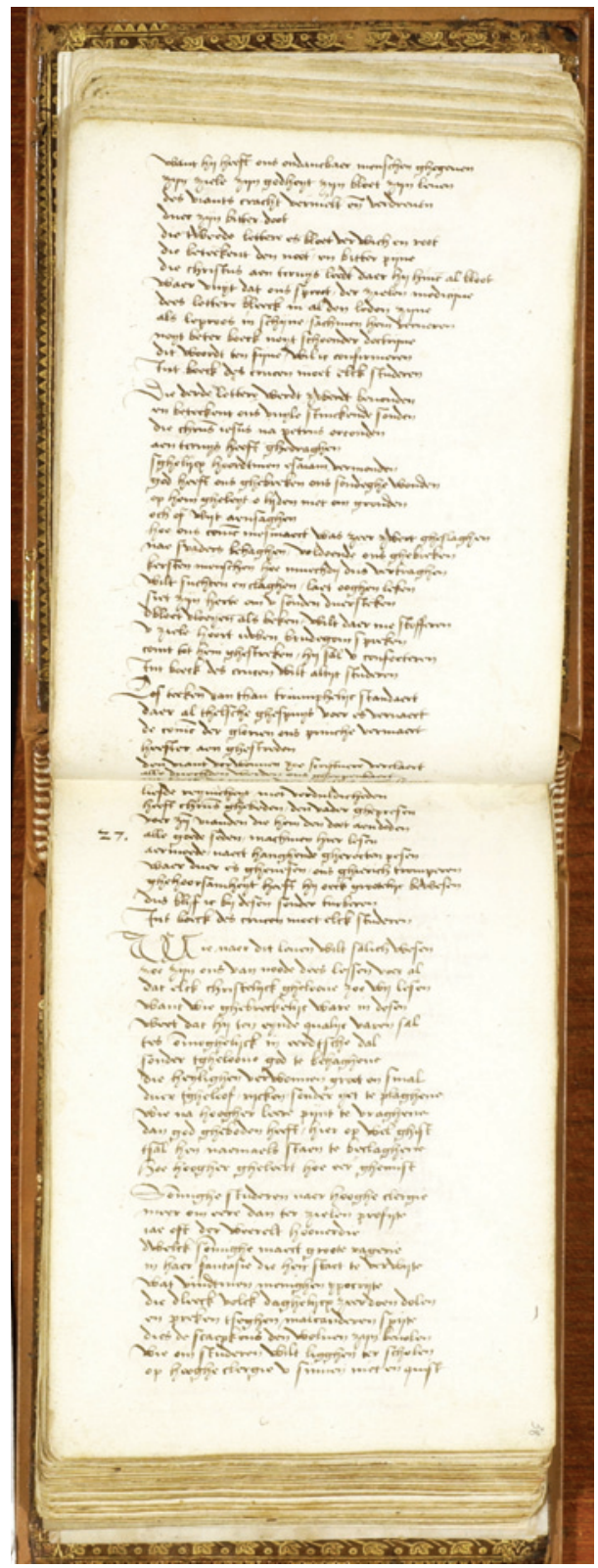

Ill. 2. MS Brussels 19547, fol. 37v-38r. The refrains, here the last stanza's from 'Int boeck des crucen moet elck studeren' ('Everyone has to study in the Book of the Cross') and the first stanza's from 'Hoe hoogher gheleert hoe eer ghemist' ('The more learned, the easier gone wrong'), are not dated in this manuscript. 
This is a beautiful and pure booklet containing many well-written and ingenious refrains full of scriptural knowledge and doctrines with a diversity of subjects, as the items in the table of contents, which follows here, tell us. [It is] very well made by the respectable and ingenious virgin Anna Bijns. [It is made] in truth refuting all these errors and serious mistakes that come from the damned Lutheran sect. This is not only justly condemned by all doctors and universities but also by the imperial majesty. ${ }^{20}$

There is no doubt: these are refrains attacking Luther. One of their many slanderous allegations is that Luther and his followers are the 'devils on earth'; the Reformer himself is called a 'fanatic monk' and 'worse than a Jew'. ${ }^{21}$

The book contains a small number of paratexts. Apart from the title, which is obviously not written by Bijns but probably by the (unknown) compiler of the book (or the publisher or printer), there are two short poems surrounding the main refrains. One poem of eleven lines precedes the refrains by way of an introduction; it contains the name of Anna Bijns as an acrostic and a modesty formula which tells the readers that this is a woman's work ('vrouwen werck'). This formula becomes important later on. In the second short poem following the refrains, Bijns uses another modesty formula, begging her readers to inform her about any mistakes, adding that she will only accept criticism from experts in rhetoricians' poetry: everyone else should remain silent:

Woman or man who knows about rhetoric

List the mistakes, for if there's anything wrong in this book

In the art, show it bravely without fear.

But he who doesn't know about these things, who isn't clever enough

At any time to read or to write:

Let it be. If you think it is bad, just let it be. ${ }^{22}$

20 'Dit is een schoon ende suverlijc boecxken / inhoudende veel scoone constige refereinen / vol scrifturen ende doctrinen / van diveerscen materien / na uut wisen der regelen / als hier int register na volgen / seer wel gemaect vander eersame ende ingeniose maecht / Anna Bijns subtilic en retorijckelic / refuterende inder warachticheit alle dese dolingen ende grote abusyen comende uut de vermaledide Lutersce secte. De welcke niet al leene van allen doctoren ende universiteyten mer ooc vander keyserlijcke majesteyt rechtverdelijc gecondemneert is.'

${ }^{21}$ Examples chosen from the poem 'Tsijn eertsche duvels die de menscen quellen' ('They are devils on earth who crucify the people'), stanza 1.

${ }^{22}$ 'Wijf oft man / wie conste can / van rethorijcken / Faulten noteert / is gefaelleert / in dit boec yet / Der consten aert / onvervaert / laet coenlic bliken / Maer die geen 
In the course of the 23 refrains Anna Bijns changes from a straightforward modesty formula (it's only women's work) to another much more self-confident statement about her poetic skills. She plays with the readers' expectations, showing off her expertise as a rhetorician.

Her first book was a great success and her work was published by well-established Antwerp printers: Van Liesvelt already issued a reprint in the same year, 1528, followed by other editions by Vorsterman in 1541, Nuyts in circa 1548, Van Ghelen in $1564 .{ }^{23}$ The first collection was published in revised editions with the second and third collection in 1646 and in 1668. The first collection was also translated into Latin in 1529 by the humanist Eligius Eucharius. ${ }^{24}$

In its long printing history few things changed; only small variations occurred, except in orthography. Though the content did not change, the title did. That of 1548 reads: 'The first book of beautiful and pure refrains full of Scriptural knowledge [...]'. The change was necessary when Nuyts not only made a reprint of the first book but also got permission to print an entirely new collection: the second book with refrains by Anna Bijns. He mostly bound the two collections together, hoping that the popular first book would fuel people's interest in the second one. ${ }^{25}$

It is assumed that the Franciscans were involved in supporting the publication of the first book. Pleij believes that the influential Franciscan preacher Matthias Weynsen was one of the main instigators of Bijns's first printed collection; he also played an important part in the publication of other pro-Catholic poetry collections and songbooks. He was, for instance, one of the two censors who, in 1539, issued the

\footnotetext{
besceet / daer af en weet / so cloec / niet / Dat hi doe / af oft toe / int lesen oft scriven / Latet soot staet / duncket u quaet / latet driven.'

${ }^{23}$ Both Van Liesvelt and Vosterman were especially well-known for their Bible editions. Van den Branden thinks that Van Liesvelt was permitted to print Bijns's book because he lived in a house that belonged to the wardens of the church of Our Dear Lady in Antwerp. Van Liesvelt must have had good connections with the clergy, and was also known as a good Christian (Van den Branden, Anna Bijns, pp. 48-49). Van Liesvelt specialized in religious literature. He published the Dutch translation of the Lutheran Bible in a new edition with Luther's commentary (1542). Being condemned for having printed clandestine books, however, he was beheaded on 28 November 1545.

${ }^{24}$ At least one copy of each of the editions survived. There are two copies of the 1528 edition: Brussels, KB, II 25.947b A1 and Maastricht, SB, $6001 \mathrm{E} 2$. The title of the Latin translation is 'Iste est pulcher et syncerus libellus [...]' ('This is a beautiful and sincere booklet').

${ }^{25}$ For an extensive list of all the printed collections see the appendix.
} 
printers' privilege for the strictly Catholic Antwerp Devoot ende profitelyck boecxken, and he is known to have encouraged more authors to write anti-Lutheran texts. ${ }^{26}$ Moreover, he knew Bijns personally. Thanks to the somewhat modified acrostic PATEh MATdIAS ANNA (meaning Pater Mattias Anna) in the last stanza of the refrain 'God grant us peace this year' ('God verleen ons vrede dit nieuwe Jaer') from the third collection - no earlier source for an acrostic with this name is known-we know that Bijns must have known someone called 'pater Mattias'. Pleij argues that in Antwerp Franciscan circles at that time this could only refer to Weynsen. We do not know what the nature of these connections was; it might be that he encouraged her to publish and that she willingly obliged. These are no far-fetched assumptions given his own anti-Lutheran background. ${ }^{27}$

Not only the first but also the second collection must have been very popular. A first edition was published in 1548 by Nuyts. In 1553, Van Ghelen printed a second edition, ${ }^{28}$ and a third one in 1565 . This collection contains many more paratexts than the first: apart from the title page and a preface, there is a number of small poems added to single refrains that are written by Bijns. Verses of two or four lines explain the reason for a refrain and sometimes even indicate which blasphemous and/or Lutheran poem was the object of her ire. The most intriguing are some texts, three poems neatly placed together at the end of the collection, which not only demonstrate Bijns's hatred for Luther but also show her own perception as well as that of someone else. The collection contains 24 refrains, 23 of them written by Anna Bijns. The 22nd was composed by an admirer, Stevijn, who has been identified as Stevijn vanden Gheenste, and thus might have been a rhetorician and priest from Bruges. ${ }^{29}$ His refrain is the centrepiece of an exchange of poems between him and Bijns in which he encourages her to persist in her struggle against Luther.

\footnotetext{
${ }^{26}$ For the publication of the songbook see Scheurleer, Een devoot ende profitelyck boecxken.

${ }^{27}$ Concerning the acrostic and about Weynsen encouraging authors to write in the way of the Franciscans see Pleij, 'Anna Bijns als pamflettiste?', pp. 202-04, and Roose, Anna Bijns, p. 46.

${ }^{28}$ The copies printed by Nuyts (circa 1548) and Van Ghelen (ca. 1553) are not dated. The date is derived from the printer's privilege which in both editions is put at the end of the collection.

${ }^{29}$ On Stevijn see Erné, Anna Bijns en Stevijn (for Bijns's readers see Roose, Anna Bijns, pp. 43-52, and Keßler, 'Wie is Cornelis Damasz?').
} 
Stevijn's refrain is not the only evidence of other people's opinions on Bijns. The preface, for example, is written by Levinus Brechtanus, a humanist and a Franciscan from Ghent, who, on that basis, is supposed to have been the compiler of this book as well. The introductory text is in Latin, perhaps to make her collection look like the product of a learned author. Brechtanus is no less full of hatred for Luther than Bijns, which immediately makes the reader aware of the anti-Lutheran nature of all the refrains of this collection. The intention of the second collection is very similar to that of the first, yet the exchange of letters with Stevijn and the laudatory preface of Brechtanus in the second volume are evidence of the fame Bijns had already acquired. Learned men now openly engaged with her works and did their best to promote them.

Van Keerberghe published the third and last collection of Bijns's poems for the first time in 1567; Vorsterman reprinted it in 1602 and 1611. Three different editions followed rapidly (1564, 1565 and 1567). In between the editions of 1565 and 1567, in 1566, the Iconoclastic Fury had taken place. In August of that year, Calvinists in Antwerp raided churches and cloisters and destroyed all symbols of the Catholic faith, from altarpieces to statues. They also destroyed the Franciscan monastery. At the end of his preface, the compiler of the third collection, Henrick Pippinck, complains that he is writing his introduction in 'our poor burnt down monastery of the Minorites'. ${ }^{30}$

For this collection, Pippinck had chosen 70 refrains that had never been published before. All of them are devotional, none of them are anti-Lutheran. The many paratexts from this collection are different from those in the first two collections. Many refrains are now followed

\footnotetext{
${ }^{30}$ It is obvious that to compile Bijns's third collection and have it printed was not an act of pure charity on Pippinck's behalf. He had a financial stake in it, and his remark about the burnt down cloister shows this clearly. He addressed his preface to 'Maria van Marmerancy' or 'Mary of Montmorency', the wife of the very influential Count of Mansvelt. They were both known as good Christians who fought for the rights of Catholics. In the preface, Pippinck praises Mary for her steadfastness in the Catholic faith and her husband, the Count of Mansvelt, who as governor was 'een van die salvatueren der Nederlant' ('one of the saviours of the Netherlands'). Mansvelt was at this time the secretary of the States-General, a very influential position, and he was probably also a very rich man. To dedicate the collection to Mary of Montmorency suggests that Pippinck hoped to get some funding for the rebuilding of the cloister. Mary of Montmorency died on 5 February 1570, three years after publication of the book. For her and her husband, Peter Ernst of Mansfelt, see: Geevers, Gevallen vazallen; De Schepper, Peter Ernst, graaf van Mansfeld; Boden, Gezin: von Mansfeld/de Montmorency-Nivelles.
} 
by poems of four to nine lines, their length being determined by the inclusion of acrostics on the name ANNA or ANNA BIINS. Most of these poems are called 'conclusions'. They refer to the preceding text, but are mostly general in nature and have little connection with the refrain: they mostly give some moral advice. It seems that these 'conclusions' are meant as the author's signatures. They might also have been composed earlier as a special type of letter sent to friends. ${ }^{31}$

The poems have religious subjects, and testify to a strong Catholic faith. In the preface Pippinck claims that the refrains compiled in this volume are meant to show sinful people how to return to the right path. He also explains that their sinfulness is the reason for the plagues with which God punishes people. His preface reflects the dominant Catholic opinion of the proper reaction to heresy: 'obedience to God, to the Church and to the authorities, was the Christian watchword. ${ }^{32}$

It is evident that in all three collections the Franciscans play an important role in compiling and editing the printed volumes. But why did they do so? Pippinck provides an explicit motive: fundraising for the rebuilding of his monastery. Yet in the two other collections, the paratexts also inform us about the motivations of the Franciscans and the gains they expected from sales of these books.

\section{MOdestly APOLOGIZING FOR HER OWN WRITING}

It is striking that in the Southern Low Countries the Franciscans seem to have needed a woman's voice to crusade against Luther. According to Pollmann, until 1566 (the year of the Iconoclastic Fury) the Catholics of the region had no reason and, it seems, no will, to fight against Luther. Only the violent action taken by the Calvinists seemed to provide a catalyst for Catholics to react in a similarly aggressive way, but until then Catholics had remained rather tolerant. ${ }^{33}$ Apart from the

31 It is also possible that they were printed first as pamphlets. If this is the case, then Pippinck would seem to be mistaken when he claims that he only wanted to edit poems that had never been printed before; or had at least not been published together in one volume. See for Bijns's poems as pamphlets: Kossmann, 'Refereynen en liedekens op losse bladen'.

32 Pollmann, 'Countering the Reformation', p. 110.

33 Pollmann points to the very different progress of the Catholic reaction in France and in the Netherlands. The French reacted much angrier and much more violent, while the Dutch stayed calm. Pollmann believes that one reason might be that in the sixteenth century much less Dutch people said to find the Mass important than 
traditional devotional works that were published in the sixteenth century, apparently only Bijns published in the vernacular against Luther in the early decades of the century. Because she was a woman, printing her works needed an apology; being female she had to overcome a number of constraints in order to be taken seriously as a poet. The general opinion was that public poetry (poems recited in public or published in print) was not a woman's occupation; an impression strengthened by the poem introducing the first collection in 1528, and in such paratexts we encounter apologetic elements. In the introductory poem to this book, Bijns asks the reader not to hold it against her if mistakes are found in the refrains, for: 'Consider that this is all the work of a woman' ('peinst tis al vrouwen werc') and that it might well be faulty ('misraect'). At first sight, Bijns seems to give the impression that literary works only amount to something if written by men. She does apologize for the audacity to take up the pen as a woman, given that in doing so she transgresses constraints set on women who were believed never to be able to write as well as a man.

Bijns modestly indicates that she was no master of poetry. However apologetic this statement sounds to modern readers, it is expressed in a poem that is excellent in form. It boasts a rather intricate rhyme scheme and contains her first and last name in acrostic. If the author was able to work in these stylistic sleights of hand without making the poem feel contrived or unnatural, how could she fear her mistakes? The apparent paradox has raised questions before; recently, Orlanda Lie was struck by it. She wondered how apparently perfect formal control and pronounced modesty could be compatible. Was Bijns not sufficiently self-confident? Lie indeed calls the combination 'paradoxical', because Bijns belies her own words: the poem is in no way 'misraect'.

French. An exception is Flanders which, as Pollmann says, 'had a very active inquisitor' (Pollmann, 'Countering the Reformation', p. 90). There was also only a limited production of books that could help people to counter the Protestants, as, according to Pollmann, devotional books just were not explicit enough. Especially in the first half of the sixteenth century only in the Southern Low Countries some publications came out against Luther. The most important are the books from Anna Bijns, because they told people what to think about the Protestants and what to do against them (ibidem, pp. 105-09); on the Dutch Revolt and its causes see, amongst many others, Woltjer, Tussen vrijheidsstrijd en burgeroorlog and Arnade, Beggars, Iconoclasts, and Civic Patriots. 
What Lie thought to be puzzling is in fact a combination of three issues that are at stake: a gender problem, a theological issue, and the commonplace of (rhetorical) modesty. The first one, the gender problem, means that Bijns, being a woman, normally would not belong to the group of people allowed to write. There are exceptions, of course, and surely there were in the Low Countries: especially in mystic literature many female writers had been active, such as Beatrijs of Nazareth and Hadewijch. Throughout the Middle Ages, more and more examples are known of women whose counsel was heeded, whose education was admired and who had authority because of their knowledge. And yet their statements concerning theological affairs and sacred subjects were always a very delicate matter. Lacey shows that 'women in general were not expected to speak of the things of God [...]. However, it does seem that in the Middle Ages it was accepted that a Holy Mystic might speak of God through visions'. ${ }^{34}$ Apparently, certain preconditions were attached to the permission to speak of God, such as living the life of a saint, of which, apart from faith, virginity was most certainly a part. Lacey illustrates this with the example of Catherine of Siena, who gained huge authority as a mystic because she remained a virgin, which is to say that her 'physical-body status was that of the holy virgin', because 'virginity has a long history as a privileged status. ${ }^{35}$

Still, women's poetry was not established yet in Bijns's time. Thus every book written by a woman needed a special reason. For the second and the third book the Franciscans provided this reason; for the first one, no other name than hers was given. She therefore had to write her own apology, in the form of a poem. The title page at least helps just a little: it claims that the book was reviewed 'by all the learned men and universities and also by the imperial majesty' ('van allen doctoren ende universiteyten mer ooc vander keyserlijcke majesteyt').

The second problem has to do with the fact that Bijns aims to play a role in a theological discussion. The title page already proclaims that the book is full of Scriptural theses and doctrines. Normally subjects like these were reserved exclusively for learned theologians. Because women were not allowed to study in a formal context such as a university, they were believed not to be able to discuss these subjects with authority. Here the reference to the learned men who reviewed the

34 Lacey, 'Gendered Language and the Mystic Voice', p. 331.

35 Ibidem. 
book becomes relevant. In both cases, the gender problem and the theological issue could be overcome by the confidence of readers in authorities who could help Bijns to be heard and heeded.

In both cases it is even more important that Bijns did not refer to herself as a self-confident writer. She had to submit to the widespread view that women should not publish. If she, as a particular exception, was granted the right to do so, she had to show gratitude and modesty. If publishing her first book meant that she might acquire fame as a writer and gain authority through her poems, then in the next book she could be more self-confident. This is precisely what happens in the second book. The poem mentioned earlier, in which she asks that only other rhetoricians react to her poems, testifies to a growing self-confidence. It was placed at the end of the book, when the reader had read all her poems and had had the opportunity to form his or her own opinions of her qualities as a skilled writer with an important message. In the introductory poem she does not take this risk of appearing too self-assured; she is modest and begs the reader's pardon in case she has made mistakes.

In the second stanza of this short poem Bijns uses the word 'conste' ('art'), in which, as she says, her 'perfection is little' ('perfectie [is] cleene'). This seems to be puzzling. Orlanda Lie apparently assumed that by 'conste' Bijns meant only the formal aspect of her work; according to her, Bijns seems to say that she is not experienced enough to use the rhetorician rules on writing refrains correctly. The rhetorician Matthijs de Castelein described in detail the various types of rhyme forms, the length of stanzas, and many other formal aspects. His Conste van rhetoriken (Art of Rhetoric, published 1555) does not deal with issues of content. Whereas Lie only focuses on the formal aspects of the notion of 'conste', in Bijns's poem 'conste' does not solely refer to 'literary errors or shortcomings'. ${ }^{36}$ I argue instead that Bijns could (also) be referring to the content of her poems. Referring to the fact that she is a laywoman who, despite the fact she is not a learned theologian, deals with complicated theological topics, she seems to point out that she could very well have made mistakes in the message she wants to convey to her readers. She does the best she can-both in form and content-but is no theologian; it is all just a woman's work: 'vrouwen werc'.

\footnotetext{
${ }^{36}$ Lie, 'Middelnederlandse literatuur vanuit genderperspectief', esp. p. 258.
} 
There is no doubt that Bijns really was treading on dangerous ground, since in a number of refrains she is arguing at a truly elevated theological level. ${ }^{37}$ The modesty formula shows Bijns as a talented rhetorician. Well aware of her very real humble sociocultural position in the prestigious field of theological argumentation, she clearly knew how to turn her disadvantage into an advantage. Bijns cleverly plays on the fact that she is a woman and that the reader knows this too. She employed the modesty formula as an important rhetorical trick giving her the freedom to speak more freely. Her skilful sophistication in the use of the modesty formula combined with her showing off her mastery of art and knowledge is characteristic of her work.

\section{Motivation FOR SPECIFIC POEMS By BIJNS}

While the modesty formula tells us something about Bijns's skills as a rhetorician and about how she wanted people to read her works, the short poems accompanying some of the refrains tell us more about why Bijns wrote them in the first place. Sometimes the possible reason is mentioned several times in the short poems that precede the refrains by way of captions. For instance, these captions appear in the second book, where they show that the refrain in question was written as a reaction to a Lutheran poem. In the second book this is the case with almost every refrain. A good example is the following verse, preceding the refrain 'And under the appearance of virtue, you search the people's coffers' ('En onder tschijn van duechden soect ghy der lien kiste'):

Against a Lutheran venomous refrain

The following was written because a friend asked me.

Of this, the stokregel was-the writer thought this was neat

'And under the appearance of virtue, they shear the sheep'. ${ }^{38}$

\footnotetext{
${ }^{37}$ For instance, in the last refrain of her first collection, 'Werden meest prophetien in zijn bruit volbracht' ('Most of the prophecies were fulfilled in his bride'), Bijns speaks about the fulfilment of Old and New Testament prophesies. To be able to treat such a subject, one had to be familiar with contemporary Bible exegesis. I believe that this was even more sensitive (and more dangerous?) for her than for the aforementioned saintly women who had visions and therefore were considered to be inspired by God. Bijns was not just the passive vessel through which God transmitted his message, but she shows her active use of reason and argumentation by entering into theological debates at such a high level.

38 'Teghen een Luters Refereyn / vol venijns / Es dnavolghende ghemaeckt duer vrients begeeren / Daer den stock af was / tdocht selcken wat fijns / En onder tschijn van duechden sy de schapen scheeren.' (p. 114)
} 
With this refrain, Bijns claims to be reacting to a Lutheran refrain 'And under the appearance of virtue, they shear the sheep' ('En onder tschijn van duechden sy de schapen scheeren'). Bijns responded by retaining the first half of the stokregel and changing the second to obtain the new one: 'And under the appearance of virtue, you search the people's coffers' ('En onder tschijn van duechden soect ghy der lien kiste'). The maxim now points out that the Lutherans merely pretend to have the best intentions, but in fact wish to rob people of their money. Bijns thus upbraids them for their greed, nicely mirroring the polemic of the Lutheran stokregel, which exposes the Catholics' greed (for instance, with reference to the selling of indulgences, a special form of sheepshearing: 'sheep' is a concept Bijns often uses for the faithful flock), ${ }^{39}$ and reversing it. Bijns used the procedure of inversion as a rhetorical trick-deliberately, it would seem.

Bijns seems to have rejoiced in writing against Luther, but sometimes suddenly returns to a modesty formula, as if she were afraid to have taken her attack too far or maybe fearing that others might think so. This is the case, for example, just before the last refrain, in a verse of seven lines. The brief rhyme is a justification and compares the polemic qualities of her refrains to the writings of the opposition:

Even if I have written something reprehensible against the Lutherans, it would be no wonder, for they write as least as hatefully against the Holy Church, to bring down faith. What I write is specifically based on the word of the Wise Man who says without mocking. You will answer the fool according to his foolishness. ${ }^{40}$

This seems to be an apologia for her aggressive style: the Lutherans write pieces that are reprehensible, because they write against the Church. It is therefore only right for her to react in the same fierce and crude manner. She supports this point with a Biblical argument, the 'word of the Wise Man', which refers to Proverbs 26:5: 'Answer a fool according to his folly, lest he be wise in his own conceit' ('Antwoerde

\footnotetext{
${ }^{39}$ Of course, Bijns is not the only one who uses this concept. It is very common in both Catholic and evangelical circles.

40 'Al hebic hier gescreven wat verwytelijc // yet / Tegen de Luteranen ten es gheen wonder // vry / Want sy scryven wel noch eens so spytelijc // siet / Teghen de heylighe kercke daer sy tonder // by / Brenghen tgheloove ic fundere bysonder // my / Opt woort dat de Wijseman sonder spot // seyt / Ghy seldt den sot antwoorde naer sijn sotheyt.' (pp. 183-84).
} 
den sot nae sine sotheit, dat hem niet en duncke, dat hi wijs si'). With the authority of the Bible she apologizes for attacking the Lutherans in general, and for the manner in which she does so in particular.

\section{The Franciscans’ Role}

The way in which Bijns presents herself in the first compilation, especially her playing with the expectations the readers might have knowing they were reading a woman's poems, she creates authority by influencing the reader precisely through his opinions about her as a poet. We have seen how she builds on this in the second compilation where she appears as highly aware of her own skills, much more so than in the first one. This owes much to Bijns's intelligent use of verses, but also to the compilers of her works, the Franciscans and other theologians. I will now discuss their views of Bijns and how they worked to increase her authority in their struggle against Luther. I will therefore focus on the prefaces of the printed compilations and the exchange of letters with Stevijn.

I already argued that the Franciscans were involved in the compilation of the three books and that Matthias Weynsen is said to have published the first volume. However, her contacts with the theologians can also be seen in another way. The second collection includes a refrain composed by one Stevijn. ${ }^{41}$ This poem is a response to an earlier refrein by Bijns, placed as number 21 in the collection. Bijns again responded with refrain number 23 in the collection, 'I am of good will, but I cannot finish it' ('Den wille is goet maer ic en cans volbringen // niet'). The 'exchange of refrains' was subsequently printed in the collection.

41 Erné only identified Stevijn with the priest and rhetorician Stevijn vande Gheeste from Bruges based on their sharing of a first name (see Erné, 'Anna Bijns en Stevijn'). However, what if this 'contact' with Stevijn just was part of the tricks the Franciscans used to give Bijns more authority? Stevijn was not engaged in publishing or compiling the collection; the author of the preface, Levinus Brechtanus, might therefore also have done the work. Of course, Stevijn's style in the refrain differs from that of Bijns: for instance, the choice of words and rhyme techniques are really different. Alternatively, what if Brechtanus used the name of (any) Stevijn, unknown to the readers among the Antwerp clergy, as an alter ego? He could then make clear that Bijns was known not only in Antwerp, but also in other regions such as Flanders. It would strengthen her authority more than contacts only within Antwerp could do. So the question is: did Erné find Bijns's real correspondent, or did he just find someone who coincidentally shared the alter ego's name? 
The stokregel of Stevijn's refrain is a double play on Bijns's motto 'meer suers dan soets' ('more sour than sweet') and on the stokregel of her own refrain: 'More sour than sweet will make the sweet taste sour' ('Meer suers dan soets / sal noch tsoete voor tsuer smaken'). Stevijn shows amazement at Bijns's poems, caused by the fact that Bijns is a woman and yet such an able composer of refrains:

A great amazement has disturbed my brain

because I saw many a male heart stumble for fear and fall dismally out of Peter's ship on which your ably rowing female spirit lives ${ }^{42}$

While many men have already given up ('have fallen from Peter's ship'), Bijns keeps on fighting for the Church, Stevijn exclaims. He clearly admires such perseverance and likes to encourage her to continue the struggle against Luther. In this way, Stevijn tells Bijns (and her readers!) how much he agrees with her and how much he adores her poetry. By being printed, of course, this poem was made known to the reader of Bijns's book. The question is: do we know for sure that this is what her admirer wanted? Did he write the poem for Bijns only and did it get into the collection by accident, or did he really write it to be read by everyone?

It is possible that initially the exchange of refrains was not meant to be published, because Bijns 'signed' her response with an acrostic of her name and that of her supporter, Stevijn, and she also added a sort of conclusion, as we have seen in the third collection, adding her name by way of four acrostics too. In a printed collection this does not make much sense. This could mean that both refrains were sent as letters first. On the other hand, the use of so many acrostics and the play on the stokregels again show Bijns's talents as a rhetorician. Stevijn's admiration can be seen as a rhetorical trick in the game of increasing her authority as a poetess who has to be taken seriously as an expert in theological matters, since she obviously can communicate on the same level with such a learned theologian.

Bijns responds to Stevijn's refrain by postulating that she will never give up the fight:

\footnotetext{
42 'Een groot verwonderen mi den sin duerteest // heeft / Siende menich manlijc herte dwelc nu bevreest // sneeft / Uut Petrus scheepken allendich gevallen // nu / In welcke cloec roeyende u vrouwelijc gheest // leeft' (stanza 1, ll. 1-4).
} 
I wish to keep on fighting them until the day I die and do not mind if I will only receive small thanks. ${ }^{43}$

On her own, however, she is too weak. What Stevijn admires-her strength as a woman-is represented by Bijns as her weakness, and she entreats the priest to join her struggle. Using a modesty formula, she says that Stevijn could do this better:

Please provide that which is lacking in me.

Show me your light, that I can light mine from you. ${ }^{44}$

At first sight, the modesty formula in this refrain clashes with the selfconfidence Bijns shows in the paratexts to this collection, in which she does not mince her words in the battle against Luther. Yet again, just as with the modesty formula in the first collection, she is playing with the expectations of the readers. She now also shows her obedience to the Church and to a priest; she clearly knows how to be modest. At the same time she argues that fighting against Luther-which Stevijn praised-is something she cannot do all by herself. If Catholics want Luther to be banished, they have to join the fight. This is especially relevant for priests:

The heretics know about my writings

but they don't take it seriously, because it's made by a woman

$[\ldots]$

You have been placed as a guardsman, so let sound the trumpet

because you find the enemies surrounding God's people ${ }^{45}$

She incites Stevijn to write against Luther too, and has a very precise idea about what he should do. According to Pollmann, in the Catholic Low Countries very little was written against Luther in the vernacular or in Latin that was useful for the faithful, ${ }^{46}$ and Bijns seems to have noticed this too. She clearly indicates that writings are very important, the more so because she probably knew Stevijn as a priest and a rhetorician, in which case he surely could take action. She invites him to

\footnotetext{
43 'Ic wil tegen hen vechten tot dat ic sterven // sal / Niet achtende al sal ic danck verwerven // smal' (stanza 5, 1l. 15-16).

${ }_{44}$ 'Vervuldt ghy tghene dat mach gebreken // my / Toont u licht datter dmyne wert ontsteken // by' (stanza 3, ll. 1-2).

${ }^{45}$ 'Legghen de ketters ooc aen mijn scrijven merck / Maer slaent voor boerte denckende tes wijven // werc / [...] / Ghy sijt wachter ghestelt laet clincken de basoen // dijn / Want gy de vianden tvolc gods omringen // siet'.

46 See Pollmann, 'Countering the Reformation', p. 108.
} 
take part in her struggle and, by printing this exchange of refrains, the compiler-who probably chose the refrains-also invites the readers to write, or at least to read the refrains attentively and follow Bijns's advice: avoid any kind of contact with the Lutherans. ${ }^{47}$

The 'problem' of women's writings, remarked on by Bijns herself, also plays a role in the third collection, published in 1567 by Van Keerberghe in Antwerp. It was compiled by Henrick Pippinck, 'minister provinciael' ('provincial head') of the Franciscan province of 'Nederduytsland' (the Low Countries). It was clearly important to him to mention in his preface the fact that he had compiled the works of a woman. It is striking that Pippinck still finds it necessary to apologize for what he had done, since the first and the second collection had been reprinted at least three times before 1567-the latest in 1564/1565. The entire city of Antwerp most likely already knew about Bijns and her opinion of Luther. As it would appear, many people bought her books-the necessity to reprint provides ample evidence.

Nonetheless, Pippinck apologizes. He seems to do this in order to stabilize and even increase her authority as a poet and lay theologian who is admired and supported by learned theologians. Pippinck therefore shows at first that the refrains are constructed 'very artfully [...] by a godly, wise, Catholic virgin' ('seer constelijck [...] van een godlijcke wijse Catholicke maget'). If there is any reader who might have some doubts, then Pippinck can provide the ultimate argument, derived from Holy Scripture itself:

Even though a virgin wrote this, do not condemn it. Learned men have read it and approved of it. Moreover, the Spirit was promised to everyone, as Joel [3:1] says: 'Your sons and daughters will prophesy, and in those days I will pour my spirit out over my servants and maids'. ${ }^{48}$

Pippinck thus provides two arguments for listening to Bijns: firstly, (learned) men have read her refrains and have approved of them, and secondly, the Bible says that God explicitly granted the gift of prophesy

\footnotetext{
${ }^{47}$ In this fragment we also encounter the only reference to the fact that Luther and/ or (some of) his followers knew about her writings, but that they did not take her seriously. Sadly, Bijns does not write more about this. Nothing is known about Lutherans reacting to Bijns's works.

48 ' [...] al ist een maghet die dit heeft gheschreven / ende wilt daeromme niet verwerpen gheleerde mannen hebbent gelesen ende geapprobeert / daerboven den Geest naer Johelis oorconde is belooft alle vleesche / u Soonen ende dochteren sullen propheteren op mijn knechten / en maerten / sal ic in die dagen van mijnen geest storten' (pp. 24-25).
} 
not to the learned, but to uneducated laymen and women. In the margin, he gives a second verse concerning this claim, Acts 2:17-18: 'In the last days, God says, I will pour out my Spirit over all people. Your sons and daughters will prophesy, your young men will see visions, your old men will dream dreams. Even over my servants, both men and women, I will pour out my Spirit in those days, and they will prophesy.' The Bible itself therefore allows women to preach about important matters in apocalyptic times, because the Holy Ghost was also poured out upon them. With such authority, Bijns's authorship was sufficiently justified: she received her inspiration from the Holy Ghost. The urgency arises because the gift of prophesy is only to be given at the end of time, as the Bible says. Bijns seems to have believed that the end was nigh, a view that is affirmed in many of her refrains too. ${ }^{49}$

Pippinck does not neglect to stress Bijns's educational credentials: he says that she taught pupils and at the same time he links her to the famous learned women known in Classical times and throughout the Middle Ages. This seems puzzling: although Bijns was a teacher, we do not know anything about her higher education. ${ }^{50}$ Pippinck does not point to a university education, but to her skills as a rhetorician and her knowledge of the Bible and the Catholic tradition. ${ }^{51}$ This is also important for the other women he lists: they are good writers and, in the best case, they know much about religious issues. He says: 'Earlier, many learned women and virgins have been found who were better than the men' ('Daer zijn hier voortijts veel geleerde vrouwen / ende maechden ghevonden die mannen hebben verwonnen'), and, among others, he mentions Cornelia, praised by Quintilian, or Diotima, who

49 The inspiration received from the Holy Ghost is also a well-known topos in rhetorician literature; see Moser, De strijd voor rhetorica, pp. 69-97. Probably the most famous example comes from the miracle play Mariken van Nieumeghen (Mary of Nimmegen) in which Mary is asked by the Devil to recite a refrain. At first, she refuses, because the composition of such a poem cannot be taught, but is a gift from the Holy Ghost. Because she has been living in sin with the Devil for seven years, she fears that she can no longer exercise this gift. But it turns out that she can do it, so her connection with God is not totally broken. There is a chance of forgiveness. A recent edition of Mariken van Nieumeghen is to be found in Ramakers and Wilmink, Mariken van Nieumeghen \& Elckerlijc.

${ }^{50}$ See her biography: Van den Branden, Anna Bijns.

${ }^{51}$ Earlier, in his Latin preface to Bijns's second collection, Levinus Brechtanus called Bijns a 'Sappho in Dutch rhymes' ('in rithmis Sappho Lesbia teutonicis'). Brechtanus is especially known as a writer of drama. His Euripus is one of the plays most frequently performed by the Jesuits-see Valentin, 'Aux origines du théatre Néo-latin'. 
was addressed with the title of 'mistress' even by Socrates. Most praise however is awarded to those women who knew the Bible, such as Catharine of Siena, Hildegard of Bingen or 'the second Apaides' ${ }^{52}$

But it is not like the woman who is so enlightened in Godly knowledge like the second Apaides who was well-versed in Holy Scripture and in the exegesis of the whole Bible. There is also Catharine of Siena, praised by Volateranus, and then there is the virgin Hildegard $[\ldots]^{53}$

According to Pippinck, many women still seem to need the approval of male authorities - as in the case of Diotima-but others, especially the latter three, no longer needed this, probably because the Holy Ghost himself enlightened them, since there was no other way in which they could know so much about the Bible. Anna Bijns seems to be one of those women.

With the third collection, Anna Bijns for the first time seems not to have been involved in the compilation and publishing process. She quite likely did have a hand in the first collection, as can be shown from the introductory poem that seems to have been specially written for this collection. The large number of paratexts by Bijns in the second collection also shows that she was engaged in that publishing project. The third collection, however, does not contain paratexts written by her other than the conclusions mentioned earlier. These, however, seem to have been disseminated earlier in the form of pamphlets. Could Pippinck be making use of Bijns's fame to support his own objectives without her knowledge ${ }^{54}$ And why did he not write any poems himself? He is very clear about this: he, the famous preacher from the pulpit, known for his sharp attacks on the heretics, ${ }^{55}$ wishes

\footnotetext{
${ }^{52}$ As far as I know it is not known who 'the second Apaides' ('childless woman' or 'virgin') is.

53 'Maer het en is niet by deser vrauwe te gelijcken / die in godlijcke scientie soo hooge is verlicht als die tweede Apaides die inder heyligher scriftuere ende het recht / verstant van den geheelen Bijbel was geverseert. Dit is die tweede Catherina van Senen die Volateranus prijst / dit is die andere maget Hildegardis [...].' 'Volateranus' presumably refers to Raffaello Maffei (1451-1522), an Italian humanist, historian and theologian who was born in Volterra, Italy. For example, Johannes Ravisius cited him for a collection of biographies of famous women, especially for the chapter on 'De moribus mulierum, et de ducenda' (see Ravisius, De memorabilibus et claris mulieribus). Volateranus also wrote an encyclopedia about all the subjects known at that time: the 'Commentariorum rerum urbanarum libri XXXVIII' (Rome, 1506). About Maffei and his works: Maissen, Von der Legende zum Modell, especially pp. 139-40.

54 Thus Roose, Anna Bijns, pp. 58-59.

${ }_{55}$ Roose, Anna Bijns, p. 57.
} 
to warn the Christians of an evil doctrine, but he just lacks the time to write:

And because I had so much work to do in the province that is given to me, and which is an unfair burden, in these Low Countries where many cloisters were robbed and destroyed and burned down with intense hate against me and my subjects, and many monks were banished, so I could not do my most important work; thus, I've seen some very fruitful books that were published many years ago by Anna Bijns, ${ }^{56}$ a respectable virgin, and they were read by many men and women, and some work was left which had never been published before, so I have compiled it for the glory of Christ and for the profit of the community $[\ldots]^{57}$

It seems strange that the famous preacher did not write himself if he had to say something so important. The fact that some good poetry was available seems fortuitous, but is this really what he wants to say? Of course, the argument might also be another rhetorical trick to turn Bijns into an authority once more: he offers his fame to add to the fame of the one who was a very talented poet and could so aptly reach laypeople with her poems.

\section{THE WORDS OF A VIRGIN}

It should always be taken into account that the compilers of the collections tried to increase Bijns's authority on theological issues by stressing her elevated knowledge of these matters, as is asserted in the title pages, by Stevijn, and by placing her in a long tradition of female writers, as Pippinck did. They all stress her respectability too. This attribute is more important than it might seem at first sight. It is closely con-

${ }^{56}$ Could Bijns - as a woman who did not have much funding - go to a printer and have her refrains printed? Pleij believes this to be an unconvincing story (Pleij, 'Komt een vrouwtje bij de drukker...'). However, nothing suggests that Pippinck believed that his Franciscan colleagues published the refrains instead of Bijns herself.

57 'Ende want door den last der provincie die my onweerdich is bevolen / in dese Neder Duytslanden daer veel Cloosters gerooft / ende ghedistruweert zijn / ja ghebrant uut grooten haet / over mijn persoone ende mijn ondersaten / veel Religieusen verjaecht / niet wetende waer si soude bevaeren / so en hebbe ic mijn principale saken niet connen absolveren / dus tot een vertoeven aenmerckende seker boecken die Anna Bijns / een eerweerdige maget over menige jaren tegen die secten heeft uut gegeven / die seer vruchtbaer zijn gheweest / ende getrocken van mannen ende vrouwen / ende noch seker werck resterende was / dat noyt ghedruckt is gheweest / so hebbe ick dat tot Christus glorie int licht ghebrocht / ende profijt der ghemeente [...]'. 
nected to another attribute that is attached to Bijns in all of the three books: her virginity.

The title page of the first book claims that it is 'very well done by the respectable and ingenious virgin Anna Bijns' ('seer wel gemaect vander eersame ende ingeniose maecht / Anna Bijns'). The second volume employs nearly the same words: it is 'done very rationally and in the manner of the Rhetoricians by the respectable and intelligent virgin Anna Bijns' ('seer subtijlijck ende Rethorijckelijck ghemaeckt vander eersame ende verstandighe maecht Anna Bijns'). In the Latin preface, Levinus Brechtanus argues that the writings of this woman are so sophisticated that a man would not have to be ashamed if he had written them ('[...] que non pudeat composuisse viros'). Brechtanus now only refers to the woman Bijns, not to the virgin; in this way increasing her authority as a female poet, not as a virgin poet. The theme of the virgin poet returns when Henrick Pippinck extols her skills. On the title page he says the refrains are 'made with great artistic competence by the honourable, devout, Catholic and very famous virgin Anna Bijns' ('ghemaect met grooter const / door die eerwerdige Godvruchtige Catholijcke / ende ser vermaerde maghet Anna Bijns'). All of these three title pages stress that the refrains are of high quality and that a very respectable virgin made them.

The recurring references in all the collections to Bijns's attribute of maidenhood can only be explained if we take a look at a collection that has merely been mentioned in passing so far: the Latin version of her first collection which was printed in Antwerp just one year after the original collection, in 1529. It was the Ghent priest, humanist and teacher Eligius Eucharius who translated the complete first collection into Latin. ${ }^{58}$ Apparently he thought it important that people from abroad could read the book. In that case it had to be translated into the Latin lingua franca, making the poems accessible to learned people who did not know Dutch. Perhaps he even hoped that Luther himself would read the book, although there is no evidence that he ever did. ${ }^{59}$ In any case, Eucharius seemed to be convinced that the aim of the

\footnotetext{
${ }^{58}$ Concerning Eucharius: Roose, Anna Bijns, pp. 65-68.

59 The fact that Luther did know what happened in the Low Countries is shown by the death of the two Augustinians mentioned at the beginning of this article. He wrote a song about this and sent a (public?) letter to the Noblemen of the Low Countries (see Akerboom and Gielis, "A new song shall begin here”). Whether he knew about all the writings against him is something that unfortunately cannot be ascertained, but it is highly unlikely.
} 
book could be made even more explicit than it already was. Eucharius took matters into his own hands: he added a Latin preface to the book in the form of a poem, placed directly above the first refrain: 'To the true lovers of the Christian religion' ('Ad veros Christiane religionis amatores'). ${ }^{60}$ The preface is to recommend Bijns's collection to the 'true Christians', that is to say the Catholics, the ones who were probably meant to read all her books; after all, they had to be warned against the Lutheran error. With this 'song' Eucharius shows that he shares Bijns's attitude towards the Lutherans. He says, for instance:

The power of the Church means death to you, cowardly Luther, most evil of soul thieves, from now on you can no longer throw deceitful deathly spears at the innocents. ${ }^{61}$

Luther will be fought with the refrains. He will lose the struggle and will no longer be able to distribute his teachings, says Eucharius. And to make Luther's defeat-thus taken for granted-even more painful, he explains by whom he will be defeated:

Not a man, but a woman will conquer you with these songs and she will crush your head with her feet. ${ }^{62}$

For Luther, it would be painful to be defeated in any case, but it would, for anyone, be even more painful to be defeated by a woman. Furthermore, he will not only be defeated, he will be utterly crushed. Here Eucharius uses an analogy that could hardly be more authoritative: Bijns crushes Luther with her refrains as Mary crushed the snake by giving birth to Christ. The snake, a motif taken from the story of Adam and Eve (alluding to Genesis 3:15), represents the Devil who was defeated through the birth of Christ and thus would no longer be able to seduce mankind. This link between the Fall and the birth of Christ is often made typologically, and the emphasis is always on the important role played by women (Eve and Mary). ${ }^{63}$ Eucharius has

${ }^{60}$ With thanks to Werner Gelderblom MA (Radboud University Nijmegen) for the translation of the entire poem and also for the Latin preface to the second volume.

${ }_{61}$ 'Ecclesiae robur, Mors tibi Luther iners / Amplius haud posthac animarum pessime latro / Subdola in innocuos spicula mortis ages.' (1l. 4-6).

${ }_{62}$ 'His te carminibus non vir sed foemina vincet-Atque tuum pedibus conteret illa caput' (1l. 7-8).

${ }^{63}$ Bijns herself often uses this image too. She frequently calls Luther and his supporters 'serpenten' ('serpents'). A good illustration is refrain no. 10 from her first collection, with the title: 'Die bi serpenten gaet crijcht vanden venijne' ('Whosoever goes to the serpent will receive poison'). 
no qualms about comparing Bijns to Mary and to attribute a similarly beneficial function to Bijns's refrains as to the birth of Christ, even more so because both women share an important characteristic: they are virgins. He delicately points out this aspect:

With the sword of reason

the virgin has cut your reins $[\ldots]^{64}$

What we see here, is an analogy between Mary and Bijns based in the first instance on what they do-release mankind from the Devil (or from Luther who is nearly as evil as the Devil) — and secondly on what attributes they share-they are both virgins. The use of the metaphor of crushing the snake's head is most important in constructing this connection between the two women. Bijns acts exactly as Mary did. Only the enemy and the way in which he is destroyed differ, but Bijns lives like Mary lived; she was also, and remained, a maiden when the destruction took place. ${ }^{65}$ The extensive parallel that is created here increases Bijns's authority as a public poet and as an expert in theological matters. It could have been the most important step in making her writings acceptable to both learned and unlearned readers. It clearly shows that learned people were reading her work and that it would be worth reading her work throughout the Christian world.

\section{Conclusion}

This study asked which strategies were employed to make Anna Bijns an authoritative voice in the struggle against Luther in and around Antwerp. We distinguished between the strategies Bijns used and those used by the Franciscans who acted as compilers and editors of her books. It can be concluded that there were important differences between these two sets of strategies.

Firstly, those of Anna Bijns herself. She often explains to the reader why she wrote a certain refrain. Here, the struggle is really evident,

64 '[...] gladio rationis habenas-Virgo tuas secuit [...]' (1l. 9-10).

${ }^{65}$ Lacey shows that the attribute of maidenhood is often used, especially in descriptions of the lives of women saints. She illustrates this with the example of Catherine of Siena, who gained huge authority as a mystic because she remained a virgin, which is to say that her 'physical-body status was that of the holy virgin', because 'Virginity has a long history as a privileged status', see Lacey, 'Gendered Language and the Mystic Voice', p. 332. 
because often a refrain is meant as a response to a Lutheran refrain. Bijns's response is on the same level as the material to which she reacts and she employs the same literary style in the same way: she writes refrains, uses the vernacular, and employs the same strategies. She calls this tactic 'answering the fool according to his foolishness', as is shown from the short poems in the second collection. In these refrains, Bijns is the pugnacious poetess who does her very best to defeat Luther. But in other ways there is also a very modest Anna Bijns. We have observed her in the first poem of the first collection, using the modesty formula and telling the reader that he surely must inform her about the mistakes in her writings. If this was meant as a sign of her humility, it is a pretence: just as in other cases where such a formula was used by male authors, the writer who used it was, according to the rhetorical principles of the time, a good poet. Here it draws attention to the remarkable fact that the formula is skilfully used by a woman. Of course, the usual game with the expectations of the reader is given an extra dimension when conducted by a woman.

Through her own writings, we encounter a fierce woman who is not afraid of Lutheran reactions. The modesty formulas-in which each reader by reading just one of the refrains will recognize the ironyonly serve to stress once more how artfully she knows to respond. There are also some important characteristics added by the image the Franciscans created as an extra layer around her. This extra layer is about the praising her talents as a writer and as a wise woman who is to be placed in a long tradition of wise women going back to the ancient world. The most important part of this image is the attribute of virginity. Maidenhood is a very relevant characteristic that is stressed many times in legends of saints. Here, it gives the Franciscans the possibility of connecting Bijns's life to that of the Virgin Mary. The Franciscans used her victory over the Devil as a parallel to Bijns's (desirable) victory over Luther. These strategies, and especially the analogy with Mary, enhance Bijns's authority. Anna Bijns, the new Mary, is the one Catholics could identify with. The idea of a woman defeating the frightened Reformer must also have been a very attractive one; it made Luther big like the devil but destructible like a snake.

These strategies were not only used in one collection but are recurrent; stressing the fact that she was a virgin had already been done in the first book, but it is restated in the Latin translation and in the second book. Pippinck, who explicitly refers to the Catholic tradition and stresses Bijns's maidenhood, most elaborately used it in the third 
book. All those involved directly in the publications of one of the printed collections, such as Eucharius, Brechtanus or Pippinck with their fulsome praise of Bijns and the stress they put on her exceptional learnedness and talent, brought about the consolidation of her status as an authoritative poet who could effortlessly hold her own in elevated theological discussions.

How could this (formally) uneducated laywoman become the mouthpiece of the learned theologians such as the Franciscans? The easiest answer is that the Franciscans were able to hide behind her. She is the one whose name is set out on the title pages, and the Franciscans only play a minor role. This is especially true in the first book, but no longer in the second and third books: in the second one, two learned men simultaneously praise Bijns's works, and the third one is created by a Franciscan. All three men are highly visible, which is true for the maker of the Latin translation too. So hiding does not seem to explain her role. Could it then be, literally, what Pippinck claims in his preface: that the Franciscans wanted to convey Bijns's message but simply did not have the time to do this themselves? This, of course, also seems far from convincing. Pippinck is the only one who makes the claim, but it seems odd that he, the famous preacher and enemy of any Reform, could not have written what he wanted to say. On the other hand, Bijns could without doubt write very well. And there is another huge advantage: she could write in the literary form that was highly preferred in her time by everyone, one of the rhetoricians' favourite forms-the refrain. She also wrote in the vernacular, so it would be easily accessible to everyone, and her language is direct and easily understood. Furthermore, Bijns is the virgin whom the editors of her second and third collections compare to the Holy Virgin Mary, because she has the weapons in her hands to crush Luther in the same way as Mary had done by crushing the snake's head.

Bijns was not the only author who was encouraged to write against Luther. Pippinck's predecessor Weynsen employed the same strategy with a number of writers. It seems to be a typical Franciscan way of disseminating their ideas: to exploit someone's talents for their own goal. The Franciscans must have believed that literary texts were attractive to the Catholics, texts that could of course be highly argumentative, which they ought to be, because the goal was to warn and arm people against the Lutheran danger. The ancient idea of the utile dulci seems to be functioning here again: it was the popular form of the refrain that could make difficult topics interesting to the readers. 
It seems evident that the Franciscans of Antwerp actively promoted Bijns to become their mouthpiece. Perhaps this idea had to grow: they, or Weynsen, could have waited to see whether the first book would be a success. When the idea proved to be unexpectedly successfulit was reprinted and, most importantly, translated into Latin-they thought about making a second one. This could also be the reason why it took so long - twenty years-before this volume was published: it had to be proven that many people would buy the first collection and that more and new refrains would be in demand. With their success, the Franciscans ventured to put themselves in the foreground by continuing to praise Bijns, but also explicitly putting their own names in the collection. The second collection was also successful, and a third collection-printed at last in 1567-must have seemed an attractive proposition.

I believe that the time gap between the first and the second collection is significant: some important parameters had changed. Luther was still active, but Bijns had become famous, the book had sold very well, and the Franciscans had the audacity not just to support her, as they did with many other authors, but even to add their names as a proof of quality and religious truth. For Bijns becoming their unique mouthpiece does not seem to have been an immediate choice of a project made at short notice, but rather the result of a long process of growth and maturing in which the impact of the first collection must be seen as a determining factor. Finally, Bijns's authority caused her work to become a fast-selling item, so that, in the third collection, Pippinck could lean on her fame as a writer of two collections still being read by the public, and on the fact that she, the well-versed lay virgin, writes so excellently that he, the learned priest, felt no need to add anything. 


\section{APPENDIX-List OF ALL PRINTS OF (AND FROM) THE THREE COLLECTIONS}

\section{First collection}

Van Liesvelt 1528, Antwerp (Dit is een schoon ende suverlijc boecxken)

- Brussels, KB, II 25.947b A1 (RP)

- Maastricht, SB, 6001 E 2

Vorsterman 1541, Antwerp (Dit is een schoon ende suyverlijc boecxken)

- Amsterdam, IISG, AB G 296 s

Nuyts [1548], Antwerp (Het yerste boeck inhoudende veel scoone constige refereynen)

- Brussels, KB, II 25.947 aA (RP)

- Den Haag, KB, 1703 G 1

- Den Haag, KB, 1703 G 2

- Den Haag, KB, 1703 G 3

- Leiden, UB, 1497 G 24

Van Ghelen 1564, Antwerp (Dits een schoon ende suyverlijck boecxken)

- Brussels, KB, II 25.948 A1 (RP)

- Paris, BNF, YI-1603

\section{Latin translation}

Vorsterman 1529, Antwerp (Iste est pulcher et syncerus libellus)

- Antwerpen, SB, C 26861

- Brussels, KB, VH 23.426 A (RP)

- Gent, UB, G 8341

- London, BL, HMNTS 3425.a.31

- Maastricht, SB, SB 6001 E 1

- Paris, BNF, RES P-YC-1045

\section{Second collection}

Nuyts [1548], Antwerp (Het tweede boeck vol schoone ende constighe refereynen)

- Brussels, KB, II 25.947b A2 (RP)

- Den Haag, KB, 1703 G 1

- Den Haag, KB, 1703 G 2

- Leiden, UB, 1497 G 24 
Van Ghelen [1553], Antwerp (Het tweede boeck vol schoone ende constighe refereynen)

- Amsterdam, IISG, AB G $296 \mathrm{~s}$

- Den Haag, KB, 1703 G 3

Van Ghelen 1565, Antwerp (Het tweede boeck vol schoone ende constighe refereynen)

- Brussel, KB, II 25.948 A2 (RP)

- Paris, BNF, YI-1604

Third collection

Van Keerberghe 1567, Antwerp (Een seer scoon ende suyver boeck)

- Brussel, KB, VH 23.873 A

- Den Haag, KB, 1703 D 39

- Gent, UB, RES 460

- London, BL, HMNTS 3433.aaaa.24

- Paris, BNF, YI-1608

- Utrecht, UB, Z Oct 1847 Rariora

- Trier, SB, W V 41

- Trier, SB, W III 118

Verdussen 1602, Antwerp, (Gheestelyck refereyn boeck)

- Amsterdam, UvA, OK 63-5971 [976 C 20]

- Brussels, KB, II 25.949 A

- Gent, UB, BL 7838

- Leiden, UB, 1497 F 39

- Paris, BNF, YI-1616

Verdussen 1611, Antwerp (Gheestelyck refereyn boeck)

- Amsterdam, IISG, AB G 299 s

- Gent, UB, BL 1976

All three collections together

Verdussen 1646, Antwerp (Konstighe refereynen vol schoone schrifture)

- Amsterdam, UvA, OK 63-5973 [976 C 22]

- Antwerpen, SB, C 16144 [C2-546 f]

- Antwerpen, Plantijn-Moretus, R 50.38

- Den Haag, KB, 839 F 10

- Groningen, UB, A 6558 
- Gent, UB, HER 1827

- Gent, UB, TA 262

- Leiden, UB, 1200 G 25

- Utrecht, UB, MOLTZER 6 C 14

Verhulst 1668, Antwerp (Konstighe refereynen vol schoone schrifture)

- Antwerpen, SB, C 12683 [C2-545 g]

- Gent, UB, HER 1431

- Gent, UB, BL 7827

- Leiden, UB, 1072 A 9: 1-3

\section{Manuscripts Cited}

Brussels, KB, II 270

Brussels, KB, 19547 (manuscript A)

Ghent, UB, 2166 (manuscript B) 

CHAPTER FOUR

\title{
THE MORALITY OF HYPOCRISY: \\ GNAPHEUS'S LATIN PLAY HYPOCRISIS AND THE LUTHERAN REFORMATION
}

\author{
Verena Demoed
}

\section{INTRODUCTION}

In drama, moral judgment is not uttered through words alone; it can also be expressed through non-verbal and seemingly subsidiary things such as props, costumes and stage action. ${ }^{1}$ This paper will attempt to clarify how Gnapheus used his Latin plays, especially his Hypocrisis ('Hypocrisy', published in 1544 and 1564), in debates on religious matters. Gulielmus Gnapheus Hagiensis, or Willem de Volder (Fuller), or Van de Voldersgraft, of The Hague (1493-1568) is an example of a committed writer. He held outspoken views on the Protestant reformations, which he expounded in pamphlets and plays. Because of his commitment, his oeuvre is pre-eminently suitable as material in an investigation of the role literature played within public debate, and the effect it may have had on public opinion. Hypocrisis is his most outspoken play. It was written and produced in East Prussia, where Lutheranism was proclaimed as a state religion. This enabled the author (he may even have felt obliged) to expound his reformational ideas in a more direct, explicit and uncompromising manner than he would have done in the Low Countries and West Prussia, where he lived before the 1540s, and which at that time still remained officially Catholic. Though even here, in Lutheran East Prussia, Gnapheus came into conflict with the ecclesiastical authorities: he was indicted for heresy by the Lutheran theologian Staphylus.

1 This paper was written within the scope of the Vidi-project Latin and Vernacular Cultures: Theatre and Public Opinion in the Netherlands (ca. 1510-1625), funded by the Dutch Organisation for Scientific Research (NWO). With thanks to J. Trapman for his comments on an earlier draft of this paper, and to A.G. Weiler for his information. All translations of Latin quotations are mine, unless stated otherwise. 
In order to decide for or against the rhetorical or even propagandistic function of drama, a contextual and intertextual approach has been chosen. I will first sketch the social context in which the play was written, staged, printed and read: that of the Latin school and University of Königsberg, where the play was performed, the court of the Duke of East Prussia, the printers and publishers of the play in Basel and Wittenberg, and Gnapheus's Lutheran critics. Furthermore, Hypocrisis will be positioned within a broader perspective: the discourse of the Reformation in general, and that of the Lutheran Reformation in particular. This paper will explain how the context of Protestant criticism affected Gnapheus's dramatic works and impinged upon other genres such as that of the vernacular morality play and on other means of communication, such as visual ones, for instance tableaux vivants, or printed ones, such as popular woodcuts. It will be argued that in his Latin plays Gnapheus makes use of the generic conventions and the same well-known motifs and representational modes that were also used by vernacular playwrights and pamphleteers. The specific sources Gnapheus used when writing his plays can no longer be traced, so this analysis will make use of representative examples, or sample texts with themes common at this time. These 'texts' are: Gnapheus's other works, Luther's writings, a Dutch table or dinner play, ${ }^{2}$ and pamphlets referred to in Scribner's work on popular propaganda during the Lutheran Reformation in Germany. ${ }^{3}$ The popular woodcuts Scribner discusses were thought to be pre-eminently suited to reach and educate the young, the illiterate and the semiliterate: 'children and simple folk, who are more easily moved by pictures and images to recall divine history than through mere words or doctrines'. ${ }^{4}$ Humanist playwrights such as Gnapheus used their dramatic works first and foremost to the same ends: to teach their pupils at the Latin schools, just as the Dutch rhetoricians tried to educate their audiences. ${ }^{5}$ At the same time, they sought to appeal, by means of a printed publication of the play, to a humanist readership. And even though both their target audiencestheir pupils and the respublica literaria-were familiar with classical antiquity, I want to show, by using a contextual approach, that Latin

\footnotetext{
${ }^{2}$ On this particular genre, see Pikhaus, Het tafelspel bij de rederijkers.

${ }^{3}$ Scribner, For the Sake of Simple Folk; idem, Popular Culture and Popular Movements in Reformation Germany.

${ }^{4}$ Scribner, For the Sake of Simple Folk, p. xi.

${ }_{5}^{5}$ Waite, Reformers on Stage, pp. 26-27, 203.
} 
drama was not just elitist ivory-tower classical humanism, and that 'classical and humanist models need not be remote from popular cultural forms, but that the one was often grafted onto the other'. ${ }^{6}$

\section{The Protestant Playwright and Pamphleteer Gnapheus}

Gnapheus was-and still is-primarily famous for his first Latin comedy Acolastus. He wrote and probably staged the play while he was a teacher and headmaster of the Latin school in his hometown of The Hague from 1522 to 1528. It was published in Antwerp in 1529, after he had fled his motherland (Holland) on religious grounds. The play was a great success: it was frequently reprinted, staged, translated into the vernacular, and adapted for other Latin dramas on the same subject. ${ }^{7}$

In the Low Countries, Gnapheus was a publicly known evangelical during the tempestuous period of the early Reformation. ${ }^{8} \mathrm{He}$ was imprisoned twice, in 1523 and 1525, the second time for having written a consolatory letter to a widow whose son had left the monastery, in which he ridiculed monastic life. ${ }^{9}$ During his three-month prison sentence-in a monastery-he states that he wrote the famous pamphlet Een troost ende spiegel der siecken ende derghenen die in lijden zijn [...] (A Comfort and Mirror for the Sick and Suffering, published in 1531). In this pamphlet he continues to attack the Catholic clergy, and to expound evangelical ideas..$^{10}$ Eventually, in 1528 , he was outlawed and fled the Low Countries for Elbing (now Elbląg), in West Prussia, in the Roman Catholic Kingdom of Poland. In Elbing Gnapheus wrote and staged the plays Triumphus Eloquentiae ('Triumph of Eloquence', published in 1541), and Morosophus ('The Foolish Sage', 1541). Both

${ }^{6}$ Scribner, For the Sake of Simple Folk, p. 64.

7 The play was translated into English by Palsgrave in 1540. See The Comedy of Acolastus. Translated [...] by John Palsgrave, ed. Carver. Some Latin adaptations are Papeus's Samarites (Samarites. Comoedia de Samaritano Euangelico, Antwerp: Montanus, 1539), and Stummelius's Studentes (written in 1545, published in 1548), see Lachmann, Die 'Studentes' des Christophorus Stymmelius und ihre Bühne.

${ }^{8}$ Spruyt, Cornelius Henrici Hoen, pp. 59-74; Roodhuyzen, Het leven van Guilhelmus Gnapheus, pp. 15-25, 81-84.

9 The letter is lost. Gnapheus mentions it in the dedication of his Tobias ende Lazarus ('Tobias and Lazarus', published in 1557), a revised edition of an earlier pamphlet, Een troost ende spiegel [...]. Ibid.

${ }_{10}$ Bibliotheca Reformatoria Neerlandica, 1, pp. 151-249. 
plays are critical of mediaeval, Roman Catholic scholasticism, and advocate either a return to the simplicity of the early Christian Church (Morosophus), or to the humanities and classical studies (Triumphus Eloquentiae). ${ }^{11} \mathrm{He}$ also published imitations of classical and biblical sources written by his pupils (Foetura, 1541), and an encomium on Elbing for its support of the bonae literae and the establishment of the Latin school (Paraenesis, 1539). ${ }^{12}$ In short, in Elbing Gnapheus concentrated wholly on the study of the classics. Gnapheus was banned from the town in 1541, this time not only because of Lutheran, but also for Sacramentarian and Anabaptist views ${ }^{13}$ even though he himself states that envy and his ideas about the marriage of priests were the cause. ${ }^{14}$ He left Elbing with wife and family, and settled for Königsberg (Polish: Królewiec, now Kaliningrad) in Lutheran East Prussia. After his arrival in Königsberg in 1541, Gnapheus became one of Duke Albert's counsellors for educational matters. ${ }^{15}$ In 1542 he began to teach at the Latin school of Königsberg. In his capacity as a teacher he wrote his last Latin play Hypocrisis, which he staged with his pupils in $1543 .{ }^{16}$

${ }_{11}$ Bibliotheca Reformatoria Neerlandica, 1, p. 140.

${ }_{12}$ Biografisch Lexicon voor de Geschiedenis van het Nederlandse Protestantisme, 4, pp. 142-44.

${ }_{13}$ De Vocht, John Dantiscus and his Netherlandish friends, p. 325; Rädle, 'Zum dramatischen Schaffen'. Sacramentarianism rejected the Roman Catholic and Lutheran doctrines of transubstantiation and consubstantiation respectively, that is, of the physical or corporeal presence of the body and blood of Christ in the bread and wine during the celebration of the Eucharist. Anabaptists are best known for their rejection of infant baptism; instead they advocated adult baptism, or baptism of the faithful. Although they were mostly pacifists and kept to themselves, their adversaries (including Luther) regarded them as violent revolutionaries. The Peasants' Revolt (1524-1525) and their bloody occupation of Münster (1534-1535) seemed to confirm these suspicions. See Hillerbrand, The Oxford Encyclopedia of the Reformation, 1, pp. 31-35; 3, pp. 462-63; Lindberg, The European Reformations, pp. 185, 199-225; and Williams, The Radical Reformation, pp. 95-108, 175-96, 528-35, 539-47, 607-17.

${ }^{14}$ Gnapheus, Antilogia, fol. A8v: ' [...] quid me, quaeso, inde pepulit, et dolentibus adeo Musis eiecit, nisi et aemulorum quorundam invidia, et ingenua aditi praeter pontificias sanctiones in domino coniugii confessio, apud Dantiscum Episcopum libere data?' ('what, I ask you, chased me away from there, and threw me out of my school, if not the jealousy of my rivals, and a frank confession voluntarily made to Bishop Dantiscus [of Warmia, VD] of a marriage in the Lord contracted in defiance of papal law').

${ }_{15}$ Hubatsch, Geschichte der Evangelischen Kirche, p. 76; Biografisch Lexicon voor de Geschiedenis van het Nederlandse Protestantisme, 4, p. 143.

${ }^{16}$ Gnapheus, Hypocrisis (1564), fol. A8 $8^{\mathrm{r}}$ ' 'Acta primo omnium Regiomonte Borussiae, in Academia recens ibi tum instituta, ludis Minervalibus, in illustrissimi Borussorum Principis praesentia, D[omino] Georgio Sabino Rectoratum gerente, Gregis vero Histrici ductore Gul[ielmo] Fullonio Gnapheo, eiusdem fabulae autore. Egere 
In 1544 the Latin school was integrated into the newly established University of Königsberg, ${ }^{17}$ and Gnapheus then became the rector of the Latin school. He also gave lectures on theology at the university, because at the time there was no qualified professor available. ${ }^{18}$

In Königsberg Gnapheus seems to have felt safe enough to finally criticize the Roman Catholic Church directly, quite explicitly, and no longer anonymously (as he had done in the aforementioned pamphlet Een troost ende spiegel), for Hypocrisis seems to be his final reckoning with Catholicism. ${ }^{19}$ His overt break with the Church, however, did not immediately make Gnapheus a devout Lutheran. At least, this was the judgement of the Lutheran ecclesiastical authorities in Königsberg, as will be shown in the next section. After the heresy trial, the ensuing excommunication from the Lutheran Church and banishment from Prussia, Gnapheus found refuge in Emden in East Frisia, at the court of Countess Anna of Oldenburg. Emden had become a safe haven for many Dutch refugees, and a Dutch church in exile was established. ${ }^{20}$ Here Protestant (mainly Calvinist) literature was printed to be distributed in the Low Countries, ${ }^{21}$ and so were some of Gnapheus's pamphlets. In Emden he published Tobias ende Lazarus, a revised version of his Een troost ende spiegel, ${ }^{22}$ the martyrology of Johannes Pistorius Woerdenatis, or Jan de Bakker (Baker) from the Dutch town of

autem Paulus Ekelus Silesita, Christophorus Pruys Regiomontanus. Israel Monetarius Mariaeburgus. Ioannes Rosenbergus Dantiscanus, et Theodoricus Montfortius, actores primarii. D[omino] Bartholomaeo Reichou, et Laurentio Meuues veteris oppidi Co[n] s[ulibu]s. Salutis nostrae anno 1543' ('Performed for the first time of all [performances of Latin plays, VD] in Königsberg in Prussia, at the newly established university, during the ludi Minervales, in the presence of the illustrious Prince of Prussia, when Georgius Sabinus was headmaster, but Gulielmus Fullonius Gnapheus, the author of this play, directed the theatre troupe. Paulus Ekelus from Silesia, Christophorus Pruys from Königsberg, Israel Monetarius from Marienburg, Ioannes Rosenbergus from Danzig and Theodoricus Montfortius played the lead. Mr. Bartholomaeus Reichou en Laurentius Meves were consul of the old city. In the year 1543').

${ }_{17}$ Von Selle, Geschichte der Albertus-Universität, p. 16; Biografisch Lexicon voor de Geschiedenis van het Nederlandse Protestantisme, 4, p. 143.

${ }_{18}$ Von Selle, Geschichte der Albertus-Universität, pp. 22-23; Mennecke-Haustein, Conversio ad ecclesiam, p. 65; Rädle, 'Zum dramatischen Schaffen', p. 232.

${ }_{19}$ Rädle, 'Theatralische Formen', pp. 280-88.

${ }^{20}$ Hillerbrand, The Oxford Encyclopedia of the Reformation, 2, pp. 39-40; Williams, The Radical Reformation, p. 540.

${ }^{21}$ Hillerbrand, The Oxford Encyclopedia of the Reformation, 2, pp. 39-40; Porteman and Smits-Veldt, Een nieuw vaderland voor de muzen, p. 57.

${ }^{22}$ Ibid. 
Woerden, first in Latin, later in Dutch, ${ }^{23}$ and a Zwinglian theological treatise: a Dutch translation of Bullinger's Summa Christlicher Religion. ${ }^{24}$ Some of his work was not specifically intended for a Dutch audience, such as his revised edition of his famous play Acolastus, the second edition of Hypocrisis, and his Antilogia, a moving (though, of course, subjective and biased) autobiographical report with a noticeably indignant tone about his fortunes in Königsberg. ${ }^{25}$ The latter two, in which Gnapheus also refutes some of the accusations made against him during the heresy trial, targeted the Lutheran elite, with the intent of rehabilitating himself after his excommunication.

\section{HYPOCRISIS AND THE HERESY TRIAL AGAINST ITS AUTHOR}

One of his colleagues in Königsberg, the theologian Fridericus Staphylus (Friedrich Stapellage, 1512-1564), who succeeded Gnapheus as lecturer in divinity at the city's university, charged Gnapheus with heresy in $1547 .{ }^{26}$ Staphylus came to Königsberg in 1546. He never made friends with Gnapheus, and personal conflicts, rather than a professional dispute, seem to have led to the trial. ${ }^{27}$ Gnapheus had to

23 Gnapheus, Johannis Pistorii a Worden, ob Evangelicae doctrinae assertionem, apud Hollandos primo omnium exusti, Vita ('The Life of Johannes Pistorius, a native of Woerden, the first to be burned in Holland because of his evangelical confession of faith', 1546); Een suverlicke ende seer schoone disputacie, welcke gheschiet is in den Haghe in Holland, tusschen die kettermeesters ende eenen Christelijcken priester ghenaemt Jan van Woorden, aldaer ghevanghen ende oock verbrant [...] ('A true and very beautiful disputation, which took place in The Hague in Holland between the inquisitors and a Christian priest named Jan, native of Woerden, who was imprisoned there and also burned', ca. 1552-1554). The Latin version was translated into Dutch and inserted in the famous Calvinist martyrology of Van Haemstede: De gheschiedenisse ende den doodt der vromen Martelaren ('The history and martyrdom of the pious Martyrs', first published in 1559).

24 Heijting, Catechismi en confessies, p. 360.

${ }_{25}$ Gnapheus, Adversus temerariam, ne dicam impiam excommunicationis censuram [...] a quibusdam Academiae Regimontanae apud Prutenos nuper institutae professoribus et concionatoribus ex mera invidia et malignandi libidine in ipsum latam, extemporalis quaedam Antilogia ("An extempore answer to the ill-considered, not to say impious, excommunication imposed on him [Gnapheus, VD] by some of the professors and instigators of the newly established University of Königsberg in Prussia out of sheer jealousy and a desire for scandal', 1551).

${ }^{26}$ Mennecke-Haustein, Conversio ad ecclesiam, pp. 65-74; Rädle, Zum dramatischen Schaffen, pp. 232-41.

27 For instance, Gnapheus criticized some of his colleagues, among them the main prosecutor Staphylus, for giving expensive, private lessons, but neglecting their public lectures. Gnapheus, Antilogia, fol. B2r . Also, Gnapheus's theses seem to have been 
defend himself extempore against Staphylus's complaints before representatives of the Lutheran Church and the university, chaired by Johannes Briesmann, the Lutheran (or, from a Catholic point of view, apostate) bishop of Samland, a secularized diocese in East Prussia. ${ }^{28}$ The evidence consisted of the theses that Gnapheus advanced when he took his doctor's degree, testimonies of witnesses, a pamphlet allegedly written by Gnapheus, and two of Gnapheus's plays: Morosophus and Hypocrisis. ${ }^{29}$

Staphylus probably did not see the plays performed, ${ }^{30}$ but he scrutinized the printed copies to collect evidence proving the author's heresy. Hypocrisis appeared in print twice. It was first published in 1544 in Basel, where Catholicism was overthrown and a Reformed Church was

written against Staphylus's teachings. Staphylus, Scriptum contra Apologiam Gnaphei, fol. $5^{\text {v: }}$ 'Sumo itaque ex isto libro nihil aliud, quam quae cum publicis erroribus concinn [e] congruere animadverto, praesertim in thematibus mihi oppositis, quos renovavit errores' ('I extract from that booklet nothing more than what I think fits [his] publicly known errors perfectly, especially those he maintained in the theses he wrote against me'). And fol. $6^{\mathrm{v}}$ : 'In non excusis thematibus proponit agnoscendi Dei modum meis disputationibus plane contrarium [...]' ('In his unpublished theses he proposes a way of knowing God explicitly contradicting my lectures'). MenneckeHaustein furthermore states that Gnapheus's collegues did not want him to give lectures on theology, being only a baccalaureus. Mennecke-Haustein, Conversio ad ecclesiam, p. 65.

${ }^{28}$ Mennecke-Haustein, Conversio ad ecclesiam, pp. 67-68; Gnapheus, Antilogia, fol. $\mathrm{C} 4^{\mathrm{v}}-\mathrm{D} 2^{\mathrm{v}}$.

${ }^{29}$ The theses and objections to them are included in Gnapheus's Antilogia (fol. B6r ${ }^{\text {- }}$ $\mathrm{C1}^{\mathrm{v}}, \mathrm{D}^{\mathrm{v}}-\mathrm{F} 4^{\mathrm{r}}$ ) and Staphylus's treatises Confrontation of Articuli Veri with Articuli falsi Gnaphei (this is a written copy of the accusations Staphylus made during the session Gnapheus asked for in order to respond to them more coherently) and Scriptum contra Apologiam Gnaphei (a response to Gnapheus's refutation of the aforementioned Confrontation of Articuli Veri with Articuli falsi Gnaphei; this 'apology' of Gnapheus has not (yet) come down to us). Neither Gnapheus nor Staphylus recorded the testimonies; Gnapheus mentions them and states they were quickly dismissed as irrelevant $\left(\right.$ fol. C $5^{r}$ ). Concerning the pamphlet, the Lutheran bishop Paul Speratus wrote a treatise against the Dutch Anabaptist refugees in Prussia, entitled Ad Batavos vagantes (To the wandering Batavians), vagantes having a double meaning of wandering, and erring, the latter refering to their unorthodox religious views. Gnapheus is accused of having written an apology in answer to this treatise in defence of the Dutch refugees: Apologetica responsio Hollandorum (Apologetical Reply of the Dutch, 1536). See also Gnapheus, Antilogia, fol. C6 ${ }^{\mathrm{v}}-\mathrm{C}^{\mathrm{r}}$; Staphylus, Scriptum contra Apologiam Gnaphei, fol. $\left.3^{\mathrm{r}}, 5^{\mathrm{r}-\mathrm{v}}\right)$; Hubatsch, Geschichte der Evangelische Kirche, p. 76; and Williams, The Radical Reformation, p. 615.

${ }^{30}$ Morosophus was staged solely in Elbing (before 22 January 1540). This is the date of Gnapheus's letter to Duke Albert in which he dedicated Morosophus to him. See Tschackert, Urkundenbuch, 1233. The date of the (official) dedicatory epistle is Christmas 1541-see Gnapheus, Morosophus, fol. A2 ${ }^{\mathrm{v}}$. Hypocrisis was performed in Königsberg in 1543, three years before Staphylus's arrival. 
established in 1529. This is the text Gnapheus's prosecutor used. Going into detail, this version of Hypocrisis indeed contains passages that do not fully correspond to Lutheran doctrines, and thus enabled the prosecutor to have Gnapheus condemned. ${ }^{31}$ Staphylus used the plays as circumstantial evidence: to show that the heretic views expressed in the theses were not a slip of the tongue, but that Gnapheus expounded these unorthodox ideas everywhere, even in seemingly innocent Latin 'school plays'. ${ }^{32}$

Staphylus accused Gnapheus of purposely passing over certain important Lutheran doctrines concerning the Law of Righteousness and the forgiveness of sins by grace, ${ }^{33}$ and of asserting that man can be freed from sin, whereas Lutherans ought to believe that even the saints are sinful. ${ }^{34}$ Last but not least, Gnapheus was accused of confus-

${ }^{31}$ To give an example of the non-Lutheran content of Hypocrisis, Rädle solely quotes Gnapheus, Hypocrisis (1544), fol. 68 (V.1): 'Simulatis qui nunc magnam sanctimoniam, / Fidemque inanem iactatis sine operibus' ('who now feign a great sanctimony, and brag about their faith, vain without works'). Rädle, Theatralische Formen, p. 285. However, Staphylus does not object to these verses in his accusations. The passage may not have been useful to him, because it can be authorized by James 2, 20: 'vis autem scire o homo inanis quoniam fides sine operibus otiosa est' ('But wilt thou know, $\mathrm{O}$ vain man, that faith without works is useless?'). Translation $K J V$ and NKJV. All the same, Gnapheus deleted these two verses (which seem to emphasize the importance of works, and therefore to oppose Lutheran dogmatics) when preparing the script for reprint in Wittenberg in 1564.

${ }^{32}$ For instance Staphylus, Scriptum contra Apologiam Gnaphei, fol. $7^{\mathrm{v}}-8^{\mathrm{r}}$ : 'Neque ego ideo ex Morosopho et Hypocrisi aliquot locos produxi, ut eius oppugnarem lucubrationes, sed quia haud pauca video esse, quae cum his thematibus conveniunt' ('I am not producing evidence from his Morosophus or Hypocrisis because I bear his lucubrations a grudge, but because I observe many things that correspond to these theses').

${ }^{33}$ Staphylus, Confrontation of Articuli Veri with Articuli falsi Gnaphei, fol. $2^{\mathrm{r}}$ : 'Gnapheus describens penitentiam in Hÿpocrisi [...] studiose praetermittit doctrinam legis damnatricis, quae patefatiat peccatum, iram Dei adversus peccatum, et condemnationem mortis aeternae propter peccatum' ('When Gnapheus is describing repentance in Hypocrisis he purposely keeps back the doctrine of the damning Law, that reveals sin, God's ire concerning sin, and the condemnation to eternal death because of sin'); and fol. 2. 'Gnapheus [...] describet [...] in Hipocrisi quomodo regenerentur Psÿche, tum nullo verbo gratuite remissionis peccatorum promissae propter Christum non meminit' ('When Gnapheus describes in his Hypocrisis how Psyche regenerates, he does not breathe a word of the forgiveness of sins by grace through Christ').

${ }^{34}$ Staphylus, Confrontation of Articuli Veri with Articuli falsi Gnaphei, fol. $3^{\text {r: }}$ 'Gnapheus fingit in sua Hipocrisi, hominem renatum, ita exui et repurgari ab omnibus pravis affectibus, ut verissima ardeat dilectione, tum Dei tum proximi' ('Gnapheus pretends in his Hypocrisis that a regenerated man has so laid down and is so cleansed of base emotions, he or she is burning for true love for God and his or her neighbour'); and fol. $2^{\mathrm{v}}$ : 'Tollunt aut certe valde extenuant Pelagiani peccatum Originale cum fingunt hominem postquam sit renatus ab omnibus pravis affectibus repurgari, 
ing the Law and the Gospel-the Law, i.e. the Old Testament with its righteous God, and the Gospel, i.e. the New Testament with its merciful, gracious God-and thus Catholicism and Lutheranism, a serious offence indeed: Staphylus assures us that 'one cannot say a more pernicious thing than this confusion'.$^{35}$ According to Parente, Catholic plays emphasize the value of good works and a strict observance of the Law in order to achieve salvation. ${ }^{36}$ Staphylus accuses Gnapheus of the same, which comes as a mild surprise, because Gnapheus seems to have written Hypocrisis for precisely the opposite reason: to show that the Roman Catholic notion of good works, such as pilgrimages, fasting, indulgences or alms-giving, is not the right way to salvation.

To state his case Staphylus quotes from an epigraph preceding the play which admonishes the reader that he can only attain salvation if he manages to repress his emotions and the fire of savage Cupid. ${ }^{37}$ Staphylus feels that Gnapheus should have ascribed salvation to faith, and not to abstinence (the repression of emotions and lust). ${ }^{38}$

cum Paulus et universa scriptura doceat in hac vita ita non tolli peccatum quin radix peccati maneat eciam in Sanctis' ('Pelagianists remove, or at least dilute, Original sin, when they pretend that after his or her regeneration he or she is cleansed of base emotions, whereas St. Paul and the Scriptures as a whole teach that sin cannot be removed during this life and that the source of sin remains even in Saints').

${ }^{35}$ Staphylus, Confrontation of Articuli Veri with Articuli falsi Gnaphei, fol. 2v: 'Legem atque Evangelium confundere plus est quam Pelagianum, cum enim lex mortis, Evangelium vero author sit vitae, nihil potest hac confusione dici pernitiosius' ('It is even worse than Pelagianism to confuse the Law and the Gospel, for the Law engenders death, the Gospel on the other hand life. Therefore one cannot say a more pernicious thing than this confusion'). See also Scriptum contra Apologiam Gnaphei, fol. $8^{\mathrm{v}}-9^{\mathrm{v}}$.

${ }^{36}$ On the difference between Catholic and Protestant plays and their respective ideas on the effectiveness of good works to attain salvation, see Parente, Religious Drama and the Humanist Tradition, p. 78-86.

${ }^{37}$ Staphylus quotes from Gnapheus, Hypocrisis (1544), fol. A1 ${ }^{\mathrm{v}}$ (epigraph, entitled IN PARTEM COMICAM / Hexastichon, 'Six verses on the comical part'): 'Qui volet astrigeri conscendere laetus Olympi / Culmina, desierit hac ubi luce frui: / Comprimat affectus, saevique Cupidinis aestum, / Et facilis praestet, quae Metanaea dabit. / Nam dabit, ut superis sit pura mente litandum, / Quo ductu verae Palladis astra petas' ('Whosoever wants to ascend in a cheerful and optimistic mood the peaks of starbearing Olympus, / when he may no longer enjoy this earthly light, / he should repress his emotions and the fire of raging Cupid, / and he will easily attain what Repentance has in store for him. / For she makes sure you will do nothing but placate the gods with your cleansed spirit, / which enables you to reach the stars under the guidance of true Wisdom').

${ }^{38}$ Staphylus, Scriptum contra Apologiam Gnaphei, fol. 9r: 'Hypo[crisis] foli 1 manifesto affirmat vitam aeternam contingere, si quis comprimat affectus atque domet libidines. Non est quod errorem brevitate, ne [nec, VD] cessitate, excuset. Quae enim potuit illum tanta necessitas cogere ut invitus vitam aeternam ascriberet operibus? Non 
Besides the epigraph Staphylus derives another argument from Act IV, where it says that God may be placated wholly by 'the deliverance from desires, which a true and living faith brings about, a holy and spiritual withdrawal, and a true heart, together with gratitude towards God'. ${ }^{39}$ Staphylus states that these lines may refer to the sacrifice of the Eucharist, but even if they do Gnapheus is still wrong: unlike Catholics, Lutherans should believe that the Eucharist can only alleviate sin, but in no way appease God altogether. ${ }^{40}$ Possibly Staphylus wants to show that Gnapheus believes-and wants his public to believe-that a believer's way of living, such as no longer being tempted by desires (puritas affectuum), or his actions, like celebrating the Eucharist, are more important than his faith. In his accusation Staphylus cunningly omits the next lines of the passage, and not surprisingly these verses happen to repudiate Catholic sanctimony. Psyche, the protagonist of the play, is talking to her 'catechist' (catechista), the allegorical character Repentance.

That is why you tell me to shun the splendour of works, invented and forced upon us by Hypocrisy and her sisters, as if they would placate God and bring salvation, while the contrary is the case, because there is no salvation for hypocrites; on the contrary, you would rather see me

patiabantur versus, inquiet. Respondeo. Satius fuit cessare, quam agere nihil. Quid obstitit, quo minus, quod operibus, id fidei tribueret?' ('On the first page of his Hypocrisis Gnapheus clearly states anyone can attain eternal life, if he subdues his emotions and tames his lusts. Without rhyme or reason he excuses his error by means of brevity or carelessness. Without reason, for what necessity, however great, could have forced him to attribute eternal life to works? "The metre wouldn't let me" he will probably say. I answer him: "It had been better to fall short, than to do nothing at all. What kept you from attributing to faith, what you attributed to works?"').

${ }_{39}$ Gnapheus, Hypocrisis (1544), IV.5 (fol. 64): '[...] tum puritas affectuum, / Fides parit quam gnesia atque vivida, / Mentis sacer recessus, et fas pectoris / Cum gratiis deo, ut decebit, redditis.'

40 Staphylus, Scriptum contra Apologiam Gnaphei, fol. 9': 'Quod si fortassis Gnapheus eo decurrat ut dicat se intelligere sarrifitia eucharistica, tamen falsum et illud erit hisce Deum placari omnifariam. Non negarim quidem propter eucharistica sarrificia renatis mitigari paenas temporales, At Deum tamen eisdem placari omnifariam, est [...] Papistarum commiscentium doctrina legis atque Evangelii. Nam unica victima, qua Deus omnifariam placatur, est solus salvator Christus Filius aeterni patris' ('However, if Gnapheus resorts to the excuse that he meant the sacrifice of the Eucharist, then it will still be erroneous to believe that the Eucharist appeases God altogether. Not that I deny that the Eucharist alleviates temporary penalties, but to believe that the Eucharist appeases God altogether, that is the Catholic confusion of the doctrine of the Law and the Gospel. For the only sacrifice to appease God altogether is Christ, the only saviour and Son of the eternal God'). 
carrying this candle of all the good, so that all may know about my faith through my pious works and virtues. ${ }^{41}$

In the second edition of 1564 Gnapheus contrasts the works to which Staphylus objected (a spiritual withdrawal, the repression of emotions, a repentant and god-fearing soul) straight away with Catholic works such as incense, liturgies, and ceremonies, with which those priests of Baal repugnantly practice their religion'; and he no longer states they appease God altogether, but that they are simply more virtuous offerings than the Catholic ones. ${ }^{42}$

In short, Staphylus does not object to the passages that denigrate certain practices within the Church (how could he, as a self-respecting Lutheran), but he does find fault with Gnapheus's exposition of evangelical belief. Gnapheus can indeed be said to expound non-Lutheran views in certain lines, but these accusations cannot be maintained when the context of the passage and the play as a whole is considered. Staphylus seems to judge the play according to the letter, but disregards the spirit. Hypocrisis is obviously an anti-Catholic polemic, but it is a Lutheran catechism as well (or so will be argued below, though on this point opinions are divided). ${ }^{43}$

It seems Gnapheus was quite affected by the heresy trial, because he thoroughly revised the text of Hypocrisis before publishing it anew in 1564 (which happens to be the year in which Staphylus died), and he deleted or modified all offensive passages. The dedicatory letter of the reprint is an elaborate apology, in which Gnapheus refutes certain allegations, and asserts that he honestly does dramatize Lutheran dogmas (viz. on the Law and the Gospel) in his Hypocrisis. ${ }^{44} \mathrm{He}$ also

${ }^{41}$ Gnapheus, Hypocrisis (1544), fol. 64 (IV.5): '[...] Facessere hinc / Ergo iubes, operum nitelas, quas mera / Hypocrisis, suis stipata sororibus / Confingit, obtruditque nobis, ceu Deo / Placeant, salutem et afferant, cum nil minus / Faciant, salus quia hypocritis nulla obtigit, / Sed lampadem hanc omnis boni vis ferre me, / Quo liceat fides mea omnibus palam / Pietatis ex operibus et virtutibus.'

${ }^{42}$ Gnapheus, Hypocrisis (1564), fol. E3 ${ }^{v}$ (IV.5): 'Mentis recessum, affectuum / Repressionem, animumque poenitentia / Tractum et Deo gratum, esse victimas, quibus / illi litetur sanctius, quam thusculis, / Liturgiis et ritibus, quae flamines / Isti Baalis absonis colunt modis.'

${ }^{43}$ See Rädle, 'Theatralische Formen', pp. 280, 283, 286-87. He contends that Gnapheus contrasts Catholicism with a Schwenckfeldian 'individual religion' rather than with Lutheranism. So too Staphylus, who not only accuses Gnapheus of Catholic inclinations, but also of Anabaptism.

${ }^{44}$ Gnapheus, Hypocrisis (1564), fol. A3 ${ }^{\mathrm{r}-\mathrm{v}}$ : '[...] quod Tragicam eius partem attinet, in qua de lege, de iactata operum a nobis electorum fiducia et iudicio (quamvis sub Hypocrisis et asseclarum ipsius persona) agitur [...] Contra vero ubi in Comica 
attacks his prosecutor, who (as Gnapheus mentions in a final remark) has by that time left the Lutheran Church and returned to Roman Catholicism. ${ }^{45}$ Gnapheus's readership was the respublica literaria, the European network of humanist scholars, but the target audience of the 1564 reprint seems to have been the Lutheran elite specifically. The revised version was printed in Wittenberg, at the heart of the Lutheran Church. Gnapheus seems to have published it with the intention of rehabilitating himself within the Lutheran community after the disgrace of his excommunication. The Wittenberg printer probably welcomed work that discredited Staphylus, who had become a fervent opponent of the Reformation, and was engaged in a polemic against Melanchthon.

\section{HYPOCRISIS AND LATIN AND VERNACULAR TRADITIONS}

Like his other Latin plays, Gnapheus wrote Hypocrisis for educational purposes at the Latin schools where he taught. The plays were performed by his pupils with the intent of contributing to the spiritual and moral education of the pupil who watched or acted in the work, but also to broaden his command of Latin [...] in order to prepare him for a life of public service to the city or the state'. ${ }^{46}$ It is an imitation or emulation of 'the language, structure, and in some cases the plots of

huius scripti parte locum illum alterum de vera poenitentia, et fide in Christum (sub poenitentis et in eiusdem Christi perlitatione acquiescentis Psyches persona) tracto [...]' ('Concerning the Tragical part [of the play, VD], which deals with the Law, and with the boastful trust we place in the works we select for their magnificence, and our judgement [concerning these works, VD] (albeit in the person of Hypocrisy and her followers) [...] However, in the Comical part of this work, where I discuss the other side of true repentance, and belief in Christ (in the person of the repentant sinner Psyche, who takes comfort with the sacrifice of the same Christ) [...]').

${ }^{45}$ Gnapheus, Hypocrisis (1564), fol. A $5^{\mathrm{r}-\mathrm{v}}$ : 'Quam sortem longe indignissimam utinam ipse non etiam serio in seipso aliquando experiatur, si non ob hoc, quod calumniose adeo annis superioribus me praeter meritum persequutus sit, sed quod non ita dudum a vera religionis Christianae professione ad Antichristi Romani partes transfuga defecerit' ('I sincerely hope he meets the same most undignified fate [that the avenging Furies punish his hypocrisy, just as happens in the play, VD], if not because all those years ago he made my life a hell with his false accusations, then because he quite recently seceded from the true Christian religion to go over to the party of the Roman Antichrist'). Staphylus converted to Catholicism in 1552.

${ }^{46}$ Parente, Religious Drama and the Humanist Tradition, p. 9. 
Greco-Roman theatre'. ${ }^{47}$ The subject matter, however, is always Christian, and often biblical.

Parente admits that humanist religious theatre was influenced by other, vernacular, forms of theatre. However, the interplay between sixteenth-century Latin drama and vernacular theatre is much more profound than the 'cunning devils, allegorical figures, and heroic saints from the late medieval tradition' he mentions. ${ }^{48}$ This is especially so in Gnapheus's Hypocrisis, but his other plays also contain elements that can only be explained and appreciated as borrowings from the vernacular tradition. ${ }^{49}$ Although Hypocrisis may be written in Latin and (with its five-act structure) cast in the form of Roman comedy, the themes (or narrative motifs) seem to be in line with the vernacular morality play, a genre practiced in the Low Countries, France, England and the German lands. This is not something out of the ordinary, ${ }^{50}$ but it may imply that Gnapheus's Latin plays are not only as emphatically moralistic and didactic as vernacular morality plays, but also just as critical and satirical. ${ }^{51}$

The most defining characteristic of the morality play is allegory, which brings to life an abstract concept or authority. ${ }^{52}$ The main use

47 Parente, Religious Drama and the Humanist Tradition, p. 7.

${ }^{48}$ Parente's definition seems to be based on later humanist religious drama, written after the 'codification of the humanist style in the late Renaissance poetics of Julius Caesar Scaliger (1561) en Gerardus Vossius (1647)', in which 'such symbiotic exchanges were discouraged', p. 6. Vernacular drama may have left hardly any traces in the later 'neo-classical style of the humanists', Baroque drama written in Latin and the vernacular (the 'cunning devils' etc.), but in the earlier examples of Latin drama its influence is much greater.

${ }^{49}$ For example, the allegorical character Philautus ('Self-love') of Acolastus as a personified vice who leads the protagonist astray; the allegorical characters Morosophus and Sophia in Morosophus, who represent feigned and true wisdom, and the theatrical form of Triumphus Eloquentiae, that may be borrowed from rhetorician processiespelen ('procession plays'). See Macardle, The Allegory of Acolastus, p. 8; Worp, Geschiedenis van het drama en het tooneel, 1, p. 235 and Demoed, Wie van gwaar houdt, pp. 118-126, 134, 167.

${ }^{50}$ See for example the Latin translations and adaptations of Elckerlijc (Every-man), Bloemendal, Transfer and Integration.

${ }^{51}$ On the moralistic and didactic nature of vernacular and Latin moralities, see Waite, Reformers on Stage; Moser, 'Maria verklaard'; Parente, Jr., Religious Drama and the Humanist Tradition. On the interplay between the moralistic and the polemical and satirical nature of French religious moralities written during the reformations, see Doudet, Statuts et figures. On the polemical and satirical nature of German drama, especially the Latin moralities of Naogeorgus, see Walz, Deutsche Literatur der Reformationszeit, pp. 117-18; Könneker, Die Deutsche Literatur der Reformationszeit, pp. 173-83; Parente, Jr., Religious Drama and the Humanist Tradition, pp. 8, 74-76.

${ }_{52}$ Ramakers, 'Dutch Allegorical Theatre', pp. 127-28. 
of allegorical tool in drama is personification, which makes the abstractions livelier: it represents immaterial things and relationships with (real and material) objects, characters and their actions. Take for example the protagonist of a standard morality play such as the famous Elckerlijc, translated into English as the-equally famous-Everyman: he represents mankind. Some morality plays have two protagonists, together representing mankind: one of them will (eventually) keep to the straight and narrow path and will be saved; the other will go astray and face damnation. The Mankind figure (or figures) is usually seduced by personified vices into going astray. Personified virtues on the other hand come to the rescue. Furthermore, in morality plays, an allegorical name (and thus meaning) is attached to objects (for example props and costumes) and to places. The characters can be liberated from their 'allegorical imprisonment'-for example, by changing their allegorical costume. In Elckerlijc, for instance, the protagonist Elckerlijc, after he has been to confession, done penance, and repented his former life, receives a robe which represents his repentance ('tCleet van Berouwenissen', 'Garment of Repentance'). ${ }^{53}$ The same thing happens in Hypocrisis: the protagonist Psyche lays down her long robe, which represents her hypocrisy; and a little later she reappears on stage in a white robe representing her uprightness. ${ }^{54}$

Allegory was a commonly used 'didactic technique', through which 'often extremely abstract questions of religion, morality and attitudes to life can be visually and comprehensibly represented to a wider audience ${ }^{55}$ Moser explains that playwrights communicate moral lessons indirectly: as the protagonist is instructed by another character, so the spectators are taught by the author of the play through the characters. ${ }^{56}$ Besides their didactic function morality plays (and other forms of allegorical drama) were often employed to expose general vices and

\footnotetext{
${ }^{53}$ Elckerlijc, 601-10. Here the idea (repentance) is turned into an object, instead of a person.

54 Gnapheus, Hypocrisis (1564), fol. E2 ${ }^{\mathrm{v}}$ (IV.3), where Repentance orders Psyche to change her dress: 'Primo ergo pone Syrma (quod trahis) longum. / Hinc rosidae fuco genae abluantur, ne / Quid Hypocriseos huc adferatur' ('To begin with, lay aside the robe you are wearing. Then you should wash the make-up from your rosy cheeks, so that you will not take along any Hypocrisy with you over here'). And fol. F1 ${ }^{\mathrm{r}}$ (V.5): 'Nivea innocentiae stola' ('a white garment of innocence'). Psyche's antagonist, Hypocrisis, on the other hand, is deprived of her white costume.

${ }_{55}$ Ramakers, 'Dutch Allegorical Theatre', p. 129.

${ }^{56}$ Moser, 'Maria verklaard', pp. 246-47.
} 
satirize historical figures. ${ }^{57}$ Especially during the performance of a play, the gestures, speech and costume can make it crystal-clear whom exactly is being attacked under the veil of allegory, however vague the dramatic text may be. ${ }^{58}$

And so does Hypocrisis: through the character Hypocrisy the play indisputably ridicules the Catholic faith.$^{59}$ How do we know Hypocrisy must be interpreted as the Church? As will be argued later, the mere mention of the name Hypocrisy already points towards this interpretation. Gnapheus makes the identification explicit in the scene in which Hypocrisy laments that she is being condemned, but only through textual references.

Where have the armies of my order gone, and the innumerable cohorts of my sworn-in Monks and Nuns? Where are the flatterers and countless servants, from among the colleges of the Cardinals raised to the purple, who never left my side while I was doing well? Where are the Jesuits, the avengers of my honour? ${ }^{60}$

Spoken remarks such as these probably easily escaped attention during a performance, but the reference is also clarified by visual means. Even to an audience unable to understand one word of Latin, the antiCatholic sentiments could be deciphered through imagery. On stage 'objects, characters and actions with "meanings" are actually made visible' ${ }^{61}$ Gnapheus had to make sure that his audience understood the code, and would be able to decrypt the link between object, character or action, and what they represented. For example, in Act II, Scene 3 the character Hypocrisy approaches the temple where she often comes and prays: it looks like a typical Roman Catholic church. Hypocrisy might merely be describing the place to the public, but this may also

\footnotetext{
${ }^{57}$ See Doudet, 'Statuts et figures'. Spaans, on the other hand, asserts that the allegorical nature of moralities functions as a veil, and prevents satire and possible controversial readings by the audience, in 'Public Opinion or Ritual Celebration of Concord'.

${ }^{58}$ Doudet, 'Statuts et figures', p. 18. On the importance of visual elements, see Ramakers, 'In utramque partem vel in plures', pp. 198, 207-13, 216-17.

${ }^{59}$ Rädle, 'Theatralische Formen', pp. 280-88.

${ }^{60}$ Gnapheus, Hypocrisis (1564), fol. D8 ${ }^{\mathrm{r}}$ (IV.1): '[...] Ubi nunc mei / Sunt ordinis centuriae, innumera cohors / Coniuratorum? Nonnos et Nonnas loquor? / Ubi sunt colaces et ciniflones plurimi, / E purpuratorum Patrum collegio, / Qui me re salva circumstabant undique? / Ubi Iesuitae, honoris nostri vindices?' The Jesuits do not yet appear in the 1544 print.

${ }^{61}$ On the importance of visual elements, see Ramakers, Dutch Allegorical Theatre, pp. 129-30.
} 
be a description of the actual décor. If so, the public would be able to recognize the setting for a Catholic church through visual indications, and readily identify Hypocrisy with Catholicism.

I am approaching the Chapel. My heart leaps up with joy, whenever I look round. For here my sanctimony can be best seen. Everywhere I turn my eyes, there are beautiful paintings, statues, the 'armour' of the priests and all the sacred things. I can hear the organ playing sweetly. Here I live and reign. Here I am worshipped as God. ${ }^{62}$

And if the public still does not understand, then Hypocrisy's costume and her actions will give further hints. Gnapheus's public was familiar with allegorizations and personified abstractions, whom it recognized by their dress and attributes. Clothing was a motif in literature, the visual arts and drama; it was also omnipresent in religious ceremony. Hypocrisy is wearing a snow-white dress and bridal veil, ${ }^{63}$ which must have reminded the audience of the alb, a white vestment worn by the Catholic clergy, and the nun's headdress. Erasmus makes use of the alb and its connotations in his Praise of Folly, when he satirizes popes, bishops and cardinals: their behavior does not correspond to the white dresses representing their innocence. ${ }^{64}$ In painting both the abstractions Catholicism and Hypocrisy were personified by a woman dressed in white; the latter, Hypocrisy, appearing as a leper or wolf beneath her clothing. ${ }^{65}$ A rhetorician allegorical play, Dwerck der Apostelen cap. 3, 4 en 5 ('The Acts of the Apostles Chapters 3, 4, and 5', before 1539), features two personified vices, who represent the sanctimony and materialism of the Pharisees (implying the same vices of

${ }^{62}$ Gnapheus, Hypocrisis (1564), fol. C3 (II.3): 'Approximo Larario. Pol gestiens / Animus novo mihi gaudio percellitur, / Quoties illud contemplor. Sanctimonia / Enim mea hic vel spectatissima redditur. / Oculi et pascuntur hic pictura nobili, / Statuis, panoplia flaminum, atque re sacra. / Aureis demulcent organôn modulamina. / Hic vivo et regno. Hic numinis loco color.' '[N]uminis loco' in the last line can also be translated as 'instead of God'.

${ }^{63}$ See for instance Gnapheus, Hypocrisis (1564), fol. C6 ${ }^{\mathrm{r}}$ (III.1), where the Fury Ate comments on Hypocrisy's costume: 'Quid, quod nive hybernia albior vestitus est?' ('What is the reason her dress is whiter than snow?'). And fol. C4: 'candido (...) flammeo' ('a white bridal veil'). This white dress and bridal veil (and Psyche's 'white garment of innocence', see note 54) could be connected to the theme of the 'ecclesia sponsa Christi', the Church as Christ's bride, based on an allegorical reading of the Song of Songs, in which the bride stands for the Church, or the soul of the individual believer (Psyche is Greek for 'Soul'), and the groom represents God or Christ.

${ }^{64}$ Erasmus, Praise of Folly, 57 and 58, ASD IV-3, pp. 170.739-172.767.

${ }^{65}$ Cesare Ripa, Iconologia of Uytbeeldinghen des Verstants (Fede Catholica and Hippocresia). 
the latter-day Catholic clergy). ${ }^{66}$ One of them, Schoon Ypocrijt ('Beautiful Hypocrite'), displays 'on his white robe virtues such as poverty, humility, devotion, and fasting, while under the cloth he is dressed as a devil, with a roll displaying the vices' ${ }^{67}$ Compare his appearance to Hypocrisis's, about which she boasts in her defense: 'I do not think I have to tell you about the virtues I am adorned with. Here you can see my chastity, there my humility. Around my chest go faith, hope and love. Nor do I have to tell you the meaning of these words, loincloth and veil'. ${ }^{68}$ Hypocrisy too, will be shown to be quite different underneath her white robe. Hypocrisy's actions complement her looks: she can be seen saying the rosary, and the ritual cleansing Asperges me is actually enacted on stage, both characteristic of Catholicism. ${ }^{69}$ In order to substantiate my claims of the play's confessional-polemic nature and its Lutheran content, a summary and an analysis of Hypocrisis will be given.

\section{The Morality of Hypocrisis}

The play's protagonist Psyche (Greek for 'Soul') is said to represent the sinful human soul, ${ }^{70}$ and she can be compared to the Mankind figure of morality plays. Apollo, the Muses, and the Graces (patrons of the humanities) will bring her to trial because of her marriage to Cupid. Cupid personifies the temptations to which the human soul is exposed. ${ }^{71}$ The marriage must be interpreted as Psyche's surrender to food, alcohol and sex, and her neglect of her studies. Psyche must

\footnotetext{
${ }^{66}$ Waite, Reformers on Stage, pp. 131-33.

${ }^{67}$ Waite, Reformers on Stage, p. 132. Hummelen, De sinnekens in het rederijkersdrama, pp. 43,45 .

${ }^{68}$ Gnapheus, Hypocrisis (1564), fol. D3' (III.3): 'Ut interim ne addam, quibus / Quam varie ornata sim virtutibus. Hic mea ecce castitas, / Est hic humilitas. Pectus ambiunt fides, spes, charitas, / Inscriptio haec, lumborum cinctus, flammeum quod arguunt.'

${ }^{69}$ Gnapheus, Hypocrisis (1564), fol. C6 ${ }^{\mathrm{r}}$ (III.1); fol. C6 ${ }^{\mathrm{v}}$ (III.2).

${ }^{70}$ Gnapheus, Hypocrisis (1564), fol. A7' (Dramatis personae): 'Psyche anima est hominis peccatoris, ingenii et eruditionis suae dotibus ad fastum, luxum, et alia nequioria abutentis' ('Psyche is the sinful human soul, abusing the gifts of her talent and knowledge on order to attain pride, luxuriousness, and other depravities').

${ }^{71}$ Gnapheus, Hypocrisis (1564), fol. A7 (Dramatis personae): 'Cupido Veneris filius amorem, reliquosque affectus et libidines signat' ('Cupid [is] Venus's son and represents love, the other passions and lust'). The 1544 print is somewhat clearer on his nature: 'Veneris filius, affectus malos et vicia animi signat' ('[he is] Venus's son and represents bad feelings and spiritual shortcomings') (fol. 10).
} 
defend her licentious lifestyle before Jove, who is sometimes referred to as Deus or Numen, and thus represents the Christian God.

In the first act we encounter a fearful Psyche who knows she is guilty and has sinned. A Fury from hell, Alecto, tries to drive her to despair and force her to commit suicide. Alecto would have succeeded were it not for the intervention of Genius, Psyche's tutelary spirit. He tells her that God is merciful and pardons even the worst sinners. Psyche's despair and Genius's ensuing hopeful words remind us of Luther's dogma of the Law and the Gospel. Psyche then asks the character Hypocrisy to plead her case in court. Because Hypocrisy represents the Roman Catholic Church, this stage action signifies that Psyche (Mankind) asks the Church to intervene on her behalf. Of course (bearing in mind Gnapheus's dislike of the Church) Hypocrisy will fail.

Hypocrisy is not very eager to defend Psyche, but in the second act she is tricked into acting as Psyche's lawyer by the personified vices Ate and Alecto, two Furies from the Underworld who have disguised themselves as Hypocrisy's trusted followers 'Religiousness' ('Religio') and 'Doctrine' ('Disciplina'). Ate and Alecto can be regarded as the humanist counterparts to the personified vices of Dutch allegorical drama; just like the vices, or sinnekens, of Dutch rhetorician theatre, Ate and Alecto act in pairs (even though the Furies from Greco-Roman mythology are usually a threesome), they are devils from hell (in this humanist drama appropriately transformed into Furies from Hades), and must disguise themselves when confronting the protagonist(s). ${ }^{72}$ Furthermore, their names, consisting of a noun which is in itself neutral, accompanied with a pejorative adjective ('feigned Religiousness', and 'false Doctrine') are similar to the Dutch convention of the sinnekens as well. ${ }^{73}$

The third act encompasses the actual trial (III. 3). The so-called 'Trial in Heaven' or the 'Satanic Trial' of vernacular morality plays may have inspired Gnapheus to write this scene. In the Trial in Heaven, Righ-

\footnotetext{
${ }^{72}$ Hummelen, De sinnekens in het rederijkersdrama, pp. 63-64, 111.

${ }^{73}$ Hummelen, De sinnekens in het rederijkersdrama, p. 35. Gnapheus, Hypocrisis (1564), fol. A7 $7^{\mathrm{v}}$ (Dramatis personae): 'Alecto Furiarum infernalium una, sub fictae interim disciplinae persona, quam induit, ultrix est male gestae rei conscientia' ('Alecto, one of the infernal Furies, is [represents, VD] the avenging conscience, while acting as feigned Doctrine'). And: 'Ate Turbarum et rixarum parens, quae et falsae religionis personam interim induit, mali omnis autorem cacodaemonem repraesentat' ('Ate, the mother of confusion and quarrels, who also performs the part of false religiousness, represents the origin of all evil, the devil').
} 
teousness and Truth plead against the defendant, whereas Mercy and Peace act in his or her favour; in a Satanic Trial a devil and Mary state their cases before God's throne. ${ }^{74}$ Hypocrisy fails to persuade Jove of Psyche's innocence (a denial of the Church's mediation between mankind and God). Worse still, she is found guilty herself, and condemned for her hypocritical behaviour and for distorting Christian religion.

For you, Hypocrisy, were always eager to act your part by means of bad fraud and ruse, all too mendacious (whether it be your words, appearance or customs), spreading threats and inflicting death upon good men. Secondly, because you have enthralled Psyche in such a way, that she perverted and neglected the true worship of God. ${ }^{75}$

She will be dragged off to Hell, to be punished by the very same devils Ate and Alecto who seduced her earlier. Psyche, on the other hand, seeks refuge in the 'altar of Mercy' (ara Misericordiae). This 'object', or prop, and the allied 'action' probably represent Psyche's repentance of her crimes, and an appeal to Jove's, or God's, mercy. God's mercy will indeed prove greater than his righteousness.

Up until now Psyche has been quite apprehensive, but now, in act IV, she is relieved because, at least for her, the trial has turned out well. It would appear that Gnapheus dramatizes the Lutheran doctrine of the Law and Gospel: the Law, that is, the Old Testament, and its righteous God instill fear, for no one can ever hope to meet the requirements of the laws of the Old Testament. The Gospel, on the other hand, presents Psyche with a merciful and forgiving God (represented on stage by the ara Misericordiae). Depictions of the antithesis of the Law and the Gospel occurred most frequently in Lutheran pedagogic propaganda. ${ }^{76}$ These kinds of theological broadsheets show that, in addition to their largely negative assaults on the Catholic Church, Lutherans tried to define their own evangelical beliefs more and more in positive terms. ${ }^{77}$ It must have been a familiar theme, all the more reason why Gnapheus dramatized it.

${ }_{74}^{74}$ Ramakers, 'Dutch Allegorical Theatre', p. 134.

75 Gnapheus, Hypocrisis (1564), fol. D5 ${ }^{\mathrm{v}}-\mathrm{D} 6^{\mathrm{r}}$ (III.4): 'Quoniam tu, Hypocrisis, vel a puero unice / Id tibi studio habuisti, ut histrionicam haud sine / Fuco et dolo faceres malo, per omnia / (Nempe ore, veste, moribus) mendax nimis, / Spirans minarum et caedium in bonos viros. / Deinde hanc tuam quia coelitus satam Psychen / Sic fascinasti, ut gnesio cultu Dei / Adulterato et negligentius habito.'

${ }^{76}$ Scribner, For the Sake of Simple Folk, p. 228.

77 Scribner, For the Sake of Simple Folk, pp. 216-19. 
Psyche is acquitted, provided that she will not return to Cupid, and only if she succeeds in asking the character Repentance (Metanoea, or Poenitentia) to lead her to the Litae, the 'offspring of Jove' (prolem Iovis), who therefore represent the Son of God, Christ. ${ }^{78}$ Psyche is now what the Lutherans might call a 'justified believer', and only now may she (and ought she to) perform good works. ${ }^{79}$ She immediately does so: she feels pity for the poor and gives alms. However, even a justified believer remains a sinner, and must keep on fighting his or her desires. ${ }^{80}$ This is enacted on stage by strife between Psyche and her former husband Cupid: Psyche must continue to prove that she no longer cares for Cupid, while continuously trying to withstand his attacks. In a morality play the protagonist progresses from a state of sin or ignorance to a state of mercy or understanding. This process is represented as a pilgrimage. Several scenes from Hypocrisis make clear that Psyche's progress from her sinful life (her marriage with Cupid) to the altar of Mercy, Repentance, Wisdom and Christ, and eventually heaven, must be regarded as a long and difficult journey. See, for example, how Psyche describes her progress to Repentance: 'Now that I have evaded the many chasms along the way and have overcome these narrow passes, I wonder whether I will truly learn to know Repentance, in such a humble shack, in such a turf hut'. ${ }^{81}$ In contrast to most people, who are deterred by Repentance's earnest appearance, Psyche enters Repentance's humble dwelling. Repentance tells Psyche to lay aside her clothes and make-up, which represents her liberation from Hypocrisy, and thus Catholicism. ${ }^{82}$

${ }^{78}$ The Litae are the (personified) Prayers of sorrow and repentance. The fact that they represent Christ is made even more explicit in Gnapheus, Hypocrisis (1564), fol. E8 ${ }^{r}$ (V.4), where Psyche says: 'Christum Domini quaero hac casa reconditum. / Quanquam Litarum sub colendo nomine' ('I am looking for Christ, the son of God, hidden in this house, even though he may be worshipped under the name of the Litae').

${ }^{79}$ Luther taught that man is justified by faith alone (sola fide), and not by doing good works. But once an individual is justified, he or she does not remain so without charitable works. See for example Lindberg, Reformation Theologians, p. 61. Justification is God's act of declaring righteous an unrighteous sinner.

${ }^{80}$ Gnapheus here dramatizes one of Luther's best-known phrases: 'simul iustus et peccator' ('at once justified and sinner', or: 'simultaneously sinner and saint').

${ }^{81}$ Gnapheus, Hypocrisis (1564), fol. E2 ${ }^{v}$ (IV.3): 'Postquam viae istius crepidines multas / Evasi et has angustiis penetravi, / Mirabor, hic si Poenitentia est vere / Discenda, sub tam humili casa atque item glebis / Tecto lare.'

${ }^{82}$ Psyche's dress is called a syrma, which was worn by actors in Greek tragedy. In Erasmus's adage Sileni Alcibiadis, which comprises an extensive critique of the 
In the fifth and final act Repentance guides Psyche towards the humble dwelling of the Litae, recognizable only by a cross, and located at the foot of a hill. The Litae, or Christ, will not appear on stage, but Pallas, divine Wisdom, guards their temple against hypocritical contrite sinners. Pallas permits Psyche to enter. After her peaceful death (contrasted to Hypocrisy's bitter end), she enters heaven. In a tableau vivant, a common dramatic technique in Dutch rhetorician drama, we see Psyche kneeling before God, or Jove, who blesses her. ${ }^{83}$

\section{Hypocrisis AND THE LUtheran Reformation}

Hypocrisis is both a satirical invective against the Church, and a dramatized Lutheran catechism, although on this last point the Lutheran theologian Staphylus fervently disagreed. An analysis of the satirical, anti-Catholic sentiments will show how Hypocrisy, and with her the Church, is represented on stage. Gnapheus refers to widely used motifs and ways of representing them: he identifies the character Hypocrisy, and thus the Church, with the hypocrites and Pharisees of the gospels; moreover, he brutalizes and demonizes the Church. Gnapheus was not the only one to do so.

The play emphasizes Hypocrisy's outward appearance, representing the Church's pomp and circumstance. For example, before appearing in court, Hypocrisy dresses up, trying to bedazzle her judge, or in other words to deceive Jove or God himself. ${ }^{84}$ And then there is the temple or shrine, where Hypocrisy is worshipped as if she were God, which looks suspiciously like a typical Roman Catholic church. By itself this temple or shrine means nothing but in comparison to the dwellings of Repentance and the Litae, or Christ, two contrasting Churches appear: a richly decorated Catholic one, and another, rather

pomp of the Church, the clergy is said to wear a tragic costume ('ornatum tragicum', ASD II-5, p. 180.433-34).

${ }^{83}$ Gnapheus, Hypocrisis (1564), fol. $\mathrm{F}^{\mathrm{r}}-\mathrm{F} 3^{\mathrm{r}}$ (Peroratio per Calliopium, 'Epilogue by Calliopius').

${ }^{84}$ See also Gnapheus, Hypocrisis (1564), fol. C6 ${ }^{\mathrm{r}}$ (III.1), where Ate tells the public what is happening behind the scenes: 'Stringit comam, faciem lavat, vultum oblinit / Ceu purpurisso. Flammeum induit novum, / Pudenda cordis aureo at strophio tegit. / Quid, quod nive hybernia albior vestitus est? [...] Videte, quam speciosa cultu appareat!' ('She is doing her hair, washing and making up her face. She puts on a new bridal veil, and covers her breasts with a golden chest ornament. What is the reason her dress is whiter than snow? Look, how fancifully dressed she appears!'). 
plain one. For example, after Genius has shown her the way, Psyche wonders whether she may find Repentance in such a humble shack, in such a turf hut'. ${ }^{85}$ This confrontation is reminiscent of Lutheran pamphlets that juxtapose the Roman Catholic Church with an evangelical one, such as the well-known and influential Passional Christi und Antichristi, which depicts and contrasts the simple life of Christ with the extravagant behaviour of the Pope. ${ }^{86}$ In the pamphlets as well as in Gnapheus's play the 'humility', 'simplicity' and 'unworldliness of Christ' or the new evangelical Church, are contrasted with 'the vices of pride, pomp and desire for possession' of the Roman Catholic Church. ${ }^{87}$ The religious message that the pamphleteers and the playwright Gnapheus want to convey to their public is the difference between true and false Christianity, Lutheranism and Catholicism.

The play also highlights Hypocrisy's sanctimony, that is, her reliance on works. Gnapheus's Hypocrisis contains several enumerations of good works. For example, when the disguised Furies try and persuade Hypocrisy to appear before Jove, they remind her of her many good deeds, such as her pilgrimages, and the persecution and execution of heretics. ${ }^{88}$ Their whole speech is delivered tongue-in-cheek, but Hypocrisy takes the bait. During the trial she repeats Ate's tactics, and recounts the good works Psyche has done, in the hope that Jove will pardon her: 'What about her grand works? What about the pilgrimages to Jerusalem? What about redeeming souls from Purgatory? What about the palms, the singing, incense, and all sorts of holy works? ${ }^{89}$ Apart from these catalogues, Hypocrisy also performs Catholic customs and rituals on stage: she recites the rosary, and says or sings Asperges me just before the trial starts.

${ }^{85}$ Gnapheus, Hypocrisis (1564), fol. E2 (IV.3): 'sub tam humili casa atque item glebis / Tecto lare.'

${ }^{86}$ The pamphlet consists of 13 pairs of woodcuts of Lucas Cranach and an accompanying explanation written by Melanchthon. It was first published in Wittenberg 1521. Scribner, For the Sake of Simple Folk, pp. 149-57.

${ }^{87}$ Scribner, For the Sake of Simple Folk, p. 155.

${ }^{88}$ Gnapheus, Hypocrisis (1564), fol. C4 $4^{\mathrm{r}-\mathrm{v}}$ (II.3).

${ }^{89}$ Gnapheus, Hypocrisis (1564), fol. D3 ${ }^{\text {r }}$ (III.3): 'ubi tum illius sunt labores maximi? Ubi peregrinationes ad Solymorum limina? / Ubi umbrarum ex teterrimi Orci faucibus redemtio? / Ubi festae frondes, cantus, thura, operosaque omne genus sacra?' See also Gnapheus, Hypocrisis (1564), fol. C2 ${ }^{\mathrm{r}}$ (II.2), where Hypocrisy complains about her predicament, undeserved after 'so many good offices, fasting, Psalms, castigation, formulas, and liturgies' ('tot curas, ieiunia, / Psalmos, flagra, cantus et liturgias'). 
From a Protestant point of view Hypocrisy's outward appearance and her sanctimony are mere hollow ceremonialism, and they will indeed prove to be of no avail; despite her looks and all her works, Hypocrisy will not successfully defend Psyche, and in addition she is found guilty herself. The Catholic 'paradigm of salvation' that Hypocrisy puts into practice leads straight to hell.

\section{Pharisees}

Empty ritualism was also ascribed to the new testamentary Pharisees. In anti-Catholic or anti-clerical literature the Catholic clergy and the Pope are often identified with the Pharisees. For example, in a rhetorician tafelspel (table or dinner play) entitled Prochiaen, Coster en Wever ('Parish Priest, Sexton and Weaver', 1538-1540), the priest says that Lutherans (such as his antagonist, the weaver) no longer attend confession but rebel against the authorities, do not perform good works, seldom go to church, do not venerate saints, and call priests like himself scribes and Pharisees (Ten vi. Seggen dat wij Priesters Scrijben zijn en Pharizeen, 'In the sixth place, they say that we Priests are nothing but Scribes and Pharisees'). ${ }^{90}$ The same identification frequently recurs in Luther's writings. For instance: 'the Pope does as the Pharisees used to do' ('Sicut papa facit, ita faciebant Pharisaei [...]'). And: 'If, on top of it all, they even become tyrants and kill the pious because of the Gospel, then a Shepherd [that is, a Priest or Bishop, VD] is no more than the devil himself. Back then the Pharisees and Scribes behaved in such a way, but right now the Pope and the Bishops, who have for a long time neglected the gospel and, made into wolves, put in its place their own traditions. Now they even persecute and kill the faithful because of the Gospel, which they should teach instead. Therefore the charade of the Pope, Cardinals and Bishops, who may be resembling Bishops, but in fact are wolves and even devils in the Church, is most terrifying. ${ }^{91}$

${ }^{90}$ Van Dis, Reformatorische rederijkersspelen, pp. 162.405-26. See also Waite, Reformers on Stage, pp. 127-31.

${ }_{91}$ Luthers Werke: kritische Gesamtausgabe, 38, p. 493.8, and 39/2, p. 73.12-13: 'Huc si accedat, ut etiam tyranni fiant, et propter verbum occidant pios, Iam nihil amplius esse Pastor, quam ipse diabolus. At tales fuerunt tunc Pharisaei et Scribae. Nunc autem Papa et Episcopi, qui iam dudum verbum neglexerunt in Ecclesia, et loco eius suas traditiones, lupi facti, intruserunt. Nunc etiam persequuntur et occidunt fideles propter verbum, quod ipsi ex officio docere tenentur. Horribilissima est igitur species ista Papae, Cardinalium, Episcoporum, qui larvati sunt Episcopi, re vera lupi 
Hypocrisis is not the first text in which Gnapheus used the motif. In the first dialogue of Gnapheus's pamphlet Een troost ende spiegel, the two spokesmen, Tobias and Timotheus, criticize the greed of their chaplain: he may appear a 'good evangelical', but he is no more than a 'hypocrite in disguise'. ${ }^{92}$ A little later the chaplain, and the Roman Catholic clergy in general, are compared to the 'feigned hypocrites and whitened sepulchres' of St. Matthew's Gospel. ${ }^{93}$ Subsequently, the Catholic clergy and the scribes are bracketed together ('Priests and scribes', 'Papen ende scriftgeleerden'), and the scribes and Pharisees are identified with the clergymen of Gnapheus's own day. ${ }^{94}$

Given that the Pharisees and hypocrites from St. Matthew's Gospel were often linked to the clergy and the Church, it is likely that spectators immediately identified the character Hypocrisy with the Pharisees by her name alone, and from there with the empty rituals of the Catholic Church. Readers (and potential buyers) on the other hand must have guessed the Protestant nature of the play as well: Hypocrisis is quite a revealing title. The Index personae further encourages this identification: 'Hypocrisy, that is, feigned sanctimony of life and religion, as can be deduced from her name' ('Hypocrisis, Simulata est vitae et religionis sanctimonia de nomine').${ }^{95}$ But the subtitle and motto on the 1564 title page in particular point Gnapheus's readership in the right direc-

et ipsi diaboli in Ecclesia.' Both stemming from works on St. Matthew's Gospel, from which Gnapheus borrowed the motto in the 1564 revised version of Hypocrisis.

${ }_{92}$ Gnapheus, Een troost ende spiegel, fol. A3 ${ }^{\text {r: }}$ 'Tobias: Wat hoor ic nv, Ick hadde ghewaent dattet een goet Euangelicsh man gheweest hadde, want hi holt hem so heylichlic opten stoel, dat ick mi daer af verwonderde, maer ic sie wel dattet niet dan een groot beueynst hypocrijt en is, Hi plach emmers selfs op die preecstoel dicwils te vercondighen, datmen hem niet sparen en solde, hy wilde oock int middel vander nacht geerne opstaen van zijn bedde' ('What do I hear now? I thought he was a good evangelical man, for he behaves so holily in the pulpit, that I was quite impressed, but now I see that he is nothing but a great hypocrite in disguise, for he himself in his pulpit has often stated that he should not be spared, and would be gladly roused from his bed in the middle of the night'). Bibliotheca Reformatoria Neerlandica, 1, p 154. Now, however, the chaplain will not come and visit their sick friend Lazarus.

${ }^{93}$ Gnapheus, Een troost ende spiegel, fol. A3 ${ }^{v}$ : '[...] beueynsde hypocrijten, ende beschilderde grauen [...].' Bibliotheca Reformatoria Neerlandica I, p 155.

${ }^{94}$ Gnapheus, Een troost ende spiegel, fol. A5 ${ }^{\mathrm{r}}$ : '[...] die Scriben ende Phariseen, die doe ter tijt alsoo stonden op haer sacrificien, feestdagen, tienden ende offerhanden, ghelijcken Hedens daghes ons Papen voor dalder heylichste ende weerdichste werc holden, missen ende ghetijen te lesen, ende den heilighen dach te vieren' ('the Scribes and Pharisees, who at that time insisted on their sacrifices, feast days, tithes, and offerings, just like today our Priests consider it as most holy and worthy to read mass and hours, and observe the Sabbath'). Bibliotheca Reformatoria Neerlandica, 1, p. 158.

${ }^{95}$ Gnapheus, Hypocrisis (1564), fol. A7 ${ }^{\mathrm{v}}$ (Index personae). 
tion: 'Hypocrisy. A Tragicomedy about the false Religiousness, feigned Discipline and punishment of an uncommonly Pharisaical Hypocrisy' (HYPOCRISIS. / DE HYPOCRISIS / PRAESERTIM PHARISAICAE FAL- / sa Religione, ficta Disciplina et supplicio (...) Tragicomoedia). Hypocrisy's epithet 'uncommonly Pharisaical' (praesertim pharisaica) points to the Pharisees. The epigraph on the same page, a quotation from St. Matthew's Gospel, completes the identification. ${ }^{96}$

\section{Foxes, wolves and the papal ass}

Gnapheus brutalizes the character Hypocrisy, and thus the Church, through animal allegory, though he does so only once, ${ }^{97}$ during Hypocrisy's exposure, shortly after the delivery of her speech in defence of Psyche, or humankind. Mercury, the messenger of the gods, is speaking directly to the audience.

You can see, good citizens, that Hypocrisy, now that her mask has been torn off, is deformed by the monsters of her vices: here lies the dog, there the pig rolls about in the mud, and she is shedding crocodile tears. Her heart is beset by the Bear, Tiger, Lion, wolf, snake and Panther. Not unlike Proteus [a god from Greco-Roman mythology, who could assume every shape and form, VD] she changes into thousands of monsters. ${ }^{98}$

Animal allegory tends toward personification, and indicates that Hypocrisy has the same characteristics as the animals mentioned: the

${ }^{96}$ Gnapheus, Hypocrisis (1564), fol. A1 ${ }^{\mathrm{r}}$ : 'Matth. XXIII. / Vae vobis Scribae et Pharisaei, Hypocritae, qui similes estis sepulcris dealbatis, quae foris quidem apparent speciosa, intus vero plena sunt ossib[us] mortuorum, omnique spurcitia. / Sic et vos quidem apparetis hominibus iusti, intus autem pleni estis hypocrisi atque impietate' ('Matthew 23, 27. Woe unto you, scribes and Pharisees, hypocrites! for ye are like unto whited sepulchres, which indeed appear beautiful outward, but are within full of dead men's bones, and of all uncleanness'). Translation KJV.

${ }_{97}$ Hypocrisy is twice closely linked with foxes. Gnapheus, Hypocrisis (1564), fol. C2 ${ }^{\mathrm{v}}$ (II.2), where Hypocrisy asks herself what will happen if word went round that she is not willing to help Psyche, one of her most loyal followers: 'Quis illic sit locusve, honosve / Hypocrisi, nisi apud Crocodeilos forsan meos / Et summos fingendi artifices vulpeculas?' ('Who will receive and honour me, Hypocrisy? No one will, except maybe my Crocodiles and the sly, little foxes'). See also Gnapheus, Hypocrisis (1564), fol. C6 ${ }^{\mathrm{r}}$ (III.1), where Ate muses on her deceit which will ruin Hypocrisy: 'Cum vulpe vulpinari ad hunc decet modum, / Cretesque fas est, mentiendo illudere' ('It is only fitting to catch a fox foxing and to lie to liars').

${ }_{98}$ Gnapheus, Hypocrisis (1564), fol. D5 ${ }^{\mathrm{r}}$ (III.3): 'Videtis, optimi cives, quantis nunc deformata sit / Viciorum monstris Hypocrisis, ut illi larvam hanc detraximus, / Canis hic iacet, hic sus volvitur, hic crocodilus fingit lachrymas. /Ursus, Tygris, Leo, lupus, vipera, Pardalis cor occupant, / Quod-ceu Protheus-in monstrorum bis mille formas vertitur.' 
predators represent her cruelty, the dog and pig (and possibly also the spotted panther) her filthiness. ${ }^{99}$ Compare this scene to one of Erasmus's most popular adages, the Silenes of Alcibiades, ${ }^{100}$ but animal allegory is also a recurring motif in the visual propaganda of the Reformation. In particular, the scene calls to mind a woodcut named The Papal Ass: It depicts the Church as a naked woman (symbolizing the whore of Babylon), covered in scales, with an ass's head, an elephant's foot, an ox hoof, and a griffin's claw. ${ }^{101}$ The Pope is also identified with predators like the lion (obviously Pope Leo X in particular), and the clergy with bears, foxes and wolves, who prey on their flock of sheep or geese. ${ }^{102}$ The same identification can already be found in Een troost ende spiegel, where Tobias criticizes the Roman Catholic clergy.

No, they are veritable wolves that Ezekiel speaks of. They drink the milk of their sheep, and they are dressed in their wool, but do not protect them from the wolves. In my opinion, they are nothing but feigning hypocrites and whited sepulchres, who suck dry widows' households and read their long prayers and hours. For this they will be judged severely, I expect; they are false Prophets in sheep's clothing, and inside they are harrowing wolves. ${ }^{103}$

${ }_{99}$ For the panther as symbol for filthiness, see Gnapheus, Morosophus, fol. F1 ${ }^{\mathrm{r}}$ (V.4): 'Cuius tu pallium alioqui candidum facis, / Maculosius sit (proh pudor) vel Pardale' ('whose normally snow-white mantle you tainted (what a shame) like a Panther'). Cf. Dante, Divina commedia, Inferno, 1, 31-33.

${ }_{100}$ Erasmus, Adagia, 2201/II. 3. 1 (Sileni Alcibiadis): 'Denique passim in omni mortalium genere sunt, quorum si formam contemplere corporis, homines et praeclaros homines dicas. Si Silenum explicueris, intus suem aut leonem aut ursum aut asinus invenies' ('Finally there are all sorts of mortals, whom you would easily assume to be men, even distinguished men, judged by their outward appearance. When opening the Silenus figure, inside you will find only pigs, lions, bears or asses'), see ASD II-5, p. 170.216-18.

101 Scribner, For the Sake of Simple Folk, pp. 129-33.

102 Scribner, For the Sake of Simple Folk, pp. 74-132.

${ }^{103}$ Gnapheus, Een troost ende spiegel, fol. A3": 'Neent, het zijn warachtige woluen, daer Ezechiel van spreect, Dat si dat melck eten van haer schapen, ende met die wolle ghecleedt werden mer si en behoedense voor die woluen niet, Ick laet my duncken, dat het zijn beueynsde hypocrijten, ende beschilderde grauen, die wtsuypen der weduwen huysen, ende langhe gebeden oft ghetyden lesen, waer omme si swaerlijcker ordeel ontfangen sullen, dit peynse ic, zijn die valsche Propheten die in schaeps cleederen gaen, ende van binnen zijnt grijpende woluen.' Bibliotheca Reformatoria Neerlandica I, p 155. It goes back to the 'false prophets' in Ezekiel (34:1-10), and combines this biblical passage with the 'hypocritical Pharisees' from St. Matthew's Gospel (23:27 and $7: 15)$. 


\section{Demonization}

Hypocrisy, and initially Psyche as well, are seduced and deceived by two devils, the two Furies from Hades, Ate and Alecto, who pose as 'angels of light', and disguise themselves as mendacious Religiousness and false Doctrine. ${ }^{104}$ Psyche repents and has recourse to the mercy of God. Hypocrisy on the other hand also acknowledges her sins, but she does not repent and even curses the gods, or God. Hypocrisy is then condemned by Jove, or God, and dragged off to hell. In this way Gnapheus shows that the Roman Catholic Church is unknowingly ruled by devils and, as it were, corrupted from the inside out.

In visual reform propaganda, the Roman Catholic Church is often associated with the demonic and with hell; the reform movement, or the Lutheran Church, are, by contrast, associated with Christ and heaven. See, for example, the last two woodcuts of the aforementioned Passional Christi und Antichristi depicting Christ's ascension, whereas the Pope 'is thrust down into hell'. ${ }^{105}$ And a popular woodcut depicting Luther preaching from the pulpit, on his right the Lutheran Church and Christ crucified, ${ }^{106}$ on his left the Pope and clergy in the jaws of hell. ${ }^{107}$ The antithetical visual propaganda of the day may have prompted the play's setting with on the one hand the house of the Litae, on the other Hypocrisy's decorated church, and later the mouth of hell that she enters. The character Hypocrisy, or the Church, is not exactly identified with the Antichrist, as in many anti-Catholic pamphlets and literary works (such as, for instance, Naogeorgus's Lutheran play Pammachius), but she is closely associated with devils and hell: she is seduced by devils, and she eventually descends into hell to be punished.

\section{ConCLusion}

Of course Gnapheus did not write and stage a religious play in an entirely Lutheran environment without any consideration for the

\footnotetext{
1042 Corinthians 11, 14: 'et non mirum ipse enim Satanas transfigurat se in angelum lucis', 'And no marvel, for Satan himself is transformed into an angel of light'. Translation KJV.

${ }^{105}$ Scribner, For the Sake of Simple Folk, pp. 154-55.

106 The humble dwelling of the Litae that Psyche visits was also identified by a cross.

${ }^{107}$ Scribner, For the Sake of Simple Folk, p. 206.
} 
convictions of his public, even though at first sight this may seem to be the case, because he was excommunicated from the Lutheran Church partly on account of his Hypocrisis, written and performed in Lutheran Königsberg. However, Gnapheus wrote an elaborate apology in which he refutes all accusations, and in abbreviated form he does roughly the same thing in the dedicatory epistle to the reprint of the play. This (admittedly thoroughly revised) version of Hypocrisis was published in Luther's own city of Wittenberg, probably with the intention of clearing the author's name, but also of discrediting his prosecutor Staphylus, who had by that time abandoned the Lutheran Church in favour of Catholicism.

Hypocrisis is a satirical attack on the Roman Catholic Church. The play emphasizes the pomp and circumstance of the Church, and Catholic practices and customs, all lumped together and embodied in the personified abstraction Hypocrisy. Hypocrisy is easily identifiable as the Church through textual references, as well as by means of costumes and stage action. Gnapheus lets Hypocrisy fail in defending Psyche (the personification of the human soul) before Jove, and in so doing he denies that the Roman Catholic Church mediates between God and man. He even allows Hypocrisy to be condemned and to descend into hell, which makes a visually persuasive argument against the Church. The fact that Hypocrisy represents Catholicism is made clearer, and cast in an unfavourable light, through her identification with the Pharisees (commonly bracketed together with the clergy), beasts of prey and devils.

Gnapheus contrasts the Church (overdressed Hypocrisy, and her adorned temple) with its exact opposite of an evangelical belief (Repentance and the Litae, or Christ, and their respective humble dwellings). Hypocrisis is thus also a dramatized Lutheran catechism. After the Roman Catholic Church has served its turn (after Hypocrisy's demise and descent into hell), the journey continues. During Psyche's allegorical pilgrimage from sin to salvation, Gnapheus dramatizes certain Lutheran tenets, such as the dogma on the Law and Gospel. In so doing Gnapheus teaches Lutheran doctrine, and strengthens his public in their new beliefs, although the theologian Staphylus held different opinions.

Just like classical drama, Gnapheus's Hypocrisis is written in Latin and divided into five acts, but that is where the similarities end. Hypocrisis is heavily indebted to the vernacular morality play. The vernacular morality plays may have appealed to Gnapheus because of their didac- 
tic and moralistic function, and suitability for satire. Above all, the play is strongly embedded in the polemical discourse of the Reformation; through his sophisticated use of various familiar and traditional motifs and modes of representation for the depiction of the Roman Catholic Church, Gnapheus fully combines aesthetics and didactics with his ardent views on reform. 



\title{
PLAYING TO THE PUBLIC, PLAYING WITH OPINION: LATIN AND VERNACULAR DUTCH HISTORY DRAMA BY HEINSIUS AND DUYM
}

\author{
Juliette Groenland
}

\section{INTRODUCTION}

A young and ambitious humanist scholar at Leiden University, Daniel Heinsius, made his name by composing a Senecan tragedy about a shocking event of consequence that was still fresh in Dutch memory: the murder of Prince William of Orange in July 1584 by the Catholic Balthasar Gerards, after King Philip II of Spain had placed a large reward on the head of the leader of the Dutch Revolt. ${ }^{1}$ Heinsius's Auriacus sive Libertas saucia ('William of Orange or Wounded Liberty', 1602) set the trend for a whole series of 'national' history dramas, ${ }^{2}$ not only in Neo-Latin but also in the vernacular, leading up to canonized exponents like Geeraerdt van Velsen (1613) and Baeto, of Oorsprong der Hollanderen ('Baeto or the Origin of the People of Holland', 1617), both by Pieter Corneliszoon Hooft, and Joost van den Vondel's Gysbreght van Aemstel (1637). The murder of William of Orange would be the subject of history plays with topical political messages for centuries to come. ${ }^{3}$ The illustrious line of vernacular plays is headed by Het moordadich stuck van Balthasar Gerards, begaen aen de doorluchtighen Prince van Oraignen. 1584 (The Murder of the Illustrious Prince of Orange Committed by Balthasar Gerards in 1584, 1606). The author,

\footnotetext{
1 This paper was written within the scope of Bloemendal's Vidi-project Latin and Vernacular Cultures: Theatre and Public Opinion in the Netherlands (ca. 1510-1625), funded by the Dutch Organisation for Scientific Research (NWO).

${ }^{2}$ I.e. history dramas about the past of the patria, a word which could be applied to a town as well as a larger geographical unity. For the concept patria within the 'Auriacus sive Libertas saucia' see Jan Bloemendal, 'Rond de Vader des Vaderlands'.

${ }^{3}$ Duits, Van Bartholomeusnacht tot Bataafse opstand, pp. 94-153 analyzes the play Wilhem of gequetste vryheyt ('William or wounded liberty', 1662) by Lambert van den Bosch; Orange plays in the 18th, 19th and early 20th centuries are listed in: Duym, Het moordadich stuck van Balthasar Gerards, ed. Serrarens and Wijngaards, p. 8.
} 
the rhetorician and war veteran Jacob Duym, presented his play in the preface to the reader as a direct adaptation of Heinsius's Auriacus. Heinsius sanctions this claim in a liminal poem, stating that Duym has thereby made the Neo-Latin play accessible to a Dutch-speaking audience.

At first sight there is a world of difference between the two Orange plays. Whereas Heinsius wrote an unbiased ancient tragedy based on topical subject matter, Duym's rhetorician drama shows clear political bias. Given the paratextual claims, scholars were struck by the liberties Duym had taken in his adaptation. Belittling the statements of both Duym and Heinsius, the twentieth-century editors of Duym's play accused the rhetorician of veiling the intended political impact of his composition in his preface 'To the reader'. ${ }^{4}$ Heinsius's laudatory poem on the other hand was explained as the naive reaction of an egocentric bookish humanist. ${ }^{5}$ In their opinion, in the play itself Duym managed to get his political message across to the man in the street, while Heinsius cast an essentially broadly based political view in an ancient mould that was deemed to have 'alienated $99 \%$ of his fellow citizens' ${ }^{6}$

Starting from the coherence between the two dramas to which the authors themselves attested, this paper explores the extent to which the heightened topicality of Duym's play could be explained as the outcome of the process of translating or (as we would be inclined to call it) adapting the drama for another audience. In order to be effective, the topical political outlook of a drama requires a close-knit tie between message and audience. Could a change in the form and mode of expression at least partly have been dictated by a change in the social and institutional setting, and the literary tradition and conventions at play? In order to substantiate this hypothesis and thus both Duym's and Heinsius's claim, it will be crucial to differentiate between the various audiences and the corresponding language and literary traditions for which the plays were intended. Was the enhanced topicality in Duym's play suggested by the transposition from the code of ancient tragedy, which had been suitable for Heinsius's intended

\footnotetext{
${ }^{4}$ Duym, Het moordadich stuck, ed. Serrarens and Wijngaards, p. 14.

${ }^{5}$ Ibidem, p. 52.

${ }^{6}$ Ibidem, p. 46.
} 
audience of fellow humanists, into the rhetorician's tradition familiar to Duym's target group? Furthermore, what can we gather about the function of the topical allusions in both dramas? Finally, on account of the extant source material, how can we assess the impact of both authors on the opinions of their public? Do the polarized judgments about the 'armchair scholar' Heinsius versus the 'people's man' Duym hold up under close scrutiny?

The relationship between the Orange plays of Heinsius and Duym raises crucial questions on the history of Dutch 'national' history drama in general. Together the plays represent a crucial stage in the emergence and development of the genre. The first Dutch national history dramas were composed in Neo-Latin. Although Heinsius was not the initiator, he certainly advocated the 'novel' genre, justifying himself in his preface to the Auriacus. Duym was the first (but not the only) vernacular dramatist directly inspired by Heinsius's Orange play, and demonstrated a tendency which would turn out to be very fruitful for the development of the genre: an ever-innovative topical treatment of the historic episode(s) at stake, adapted to the political situation of the moment. The insights gained about the connection between Heinsius and Duym throw light on the general interrelation between Neo-Latin and vernacular dramatists and their audiences. How far is this analysis in keeping with the common notion that the conservative and elitist Latin literary productions were pushed aside by competing vernacular counterparts produced more by and for the common people? Do Heinsius's and Duym's plays really represent conflicting opposites of a world in transition, or does their relationship point towards two coexisting and interfering cultural fields? Since topicality and public opinion play a key role in the way both dramatists try and interact with their audiences, what can this case study tell us about the relationship between early modern literature and public opinion in general? A short introduction to early Dutch history drama and the particular topical outlook of the genre will be followed by an analysis of the Orange plays by Heinsius and Duym: their allusions to contemporary politics on the one hand, the contexts in which they were composed and their (intended and actual) audiences on the other hand. Finally, I will discuss the particular relationship of the two plays: what do we learn about the relationship between Latin and vernacular authors and their audiences in general, and about the way the plays interact with the opinion or opinions of their audiences in particular? 


\section{EARLY DUTCH HISTORY DRAMA}

In the Dutch Republic as well as in other countries, history drama was revived and was brought to fruition in a period of heightened political awareness and intensified national consciousness. The decade after the defeat of the Armada bore witness to the majority of the great English history plays. ${ }^{7}$ In Spain Lope de Vega and his fellow playwrights produced historical dramas hailing Spain's destiny to rule the world. French history drama of the seventeenth century explored not the national but the Roman past for analogies with contemporary France; this might be explained by the authoritarian regime, ${ }^{8}$ the available national historical material, or the prevailing classicism..$^{9}$ In Germany, it would not be until the upsurge of nationalism in the age of Goethe that the German past would become a source of inspiration to playwrights.

Dutch history drama, like its Spanish and English counterparts, experienced its prime during the early seventeenth century. ${ }^{10}$ At the time of the Dutch Revolt, the subject matter of tragedies was no longer restricted to traditional biblical episodes. During the heated political and religious controversies, the playwrights explored highly disputed events from recent history. Previous research into English and Spanish Renaissance drama ${ }^{11}$ has established that the date of composition of a history play is a major determinant of both the nature of the historical representation and of the topical comment. Noak and Duits reached a similar conclusion concerning the Dutch Republic. However, their studies discuss plays in the vernacular only and cover a later period. ${ }^{12}$

Just as it has been argued that Spanish and English national history plays represent two separate traditions developing for the greater part independently, ${ }^{13}$ (northern) Dutch history drama seems to represent an independent line with its own dynamics as well. Outlining

7 Lindenberger, Historical Drama, pp. 6-7.

${ }^{8}$ Ibidem, p. 7 points out that none of Shakespeare's English plays were written in the time of the Tudors; similarly, Henry VIII, stemming from the Stuart reign, is less political in content and method than the pre-Tudor plays.

${ }^{9}$ Loftis, Renaissance Drama in England and Spain, p. 6.

${ }^{10}$ See Groenland, 'The Deadly Earnest of History Plays'.

${ }^{11}$ Loftis, Renaissance Drama in England and Spain.

12 Duits, Van Bartholomeusnacht tot Bataafse opstand discusses plays from the period 1645-1663; a wider range, 1606-1673, is represented in Noak, Politische Auffassungen im niederländischen Drama des 17. Jahrhunderts.

${ }^{13}$ Loftis, Renaissance Drama in England and Spain, p. 4. 
the extant early specimens of the genre, from the period 1580-1625, representing the turbulent Dutch Republic in the making, the following dramas can be counted among the tradition:

(Panagius Salius (Toussaint du Sel), Nassovius (1589)) $)^{14}$

Caspar Casparius (Caspar Ens), Princeps Auriacus sive Libertas defensa (The Prince of Orange or Liberty Defended, 1598)

Daniel Heinsius, Auriacus sive Libertas saucia (1602)

Jacob Duym, Het moordadich stuck van Balthasar Gerards, begaen aen de doorluchtighen Prince van Oraignen (1606)

Gijsbrecht van Hogendorp, Treur-spel van de moordt (Tragedy of the Murder, 1616)

Pieter Corneliszoon Hooft, Geeraerdt van Velsen (1613) and Baeto, of Oorsprong der Hollanderen (Baeto or the Origin of the People of Holland, 1617)

Govert vander Eembd, Haerlems belegerings treur-blij-eynde-spel (1619) Jacobus Zevecotius (Jacques de Zevecote), Maria Stuarta / Maria Graeca (1623/1625), and Belegh van Leyden. Treurspel (Siege of Leiden. A Tragedy, $1626(1632))$.

This list of history dramas shows that Heinsius's Auriacus was preceded and inspired by an Orange play of the Delft Deputy Headmaster Caspar Ens, as the subtitle of Heinsius's play explicitly shows. ${ }^{15}$ Caspar Ens's Orange play, probably performed at the Latin school in Delft and published together with a political pamphlet, may have reached a considerable audience. ${ }^{16}$ Daniel Heinsius's Auriacus, however, became the trendsetter, extending its influence even to the history dramas by Hooft or Zevecotius's Maria Stuarta, treating contemporary issues under the cloak of more distant historical events.

Overall, the list reveals the manifold levels on which these history plays reflect different cultural, institutional and social fields: plays in

${ }_{14}$ The first Orange play originated in the Southern Low Countries and is a proSpanish portrayal of William of Orange as a tyrant. However, it seems Salius's drama remained unknown in the Dutch Republic. To this list other tragedies could be added, for instance Govert vander Eembd, Haerlems belegerings treur-blij-eynde-spel (1619), but I will restrict myself to treating the tragedies that belong to one single cluster.

${ }^{15}$ The title of Heinsius's Auriacus sive Libertas saucia not only shows the author's indebtedness to his predecessor, but articulates at the same time, according to the good humanist principle of imitatio et aemulatio, the different outlook of the two dramas. The message of Casparius's play was ultimately an optimistic one, whereas Heinsius, bent on composing a true 'tragic' tragedy, emphasized the damage that had been done to Liberty.

${ }^{16}$ For a modern edition with translation in Dutch see Ens, Princeps Auriacus, ed. Bloemendal and Steenbeek; for a discussion of the political purport of the play and its publication see Groenland, 'Toneel als pamflet?'. 
Neo-Latin as well as in the vernacular, conceived in humanist strongholds like the Latin school or the university as well as in the chambers of rhetoric and the newly built Amsterdam theatre. Nonetheless, the autonomous development of the genre within the Dutch Republic, cutting right across all these fields, supports the supposition that authors such as Duym and Heinsius, at least up to a certain point, worked in the same cultural domain. All the history dramas appeal somehow to the collective memory of the young Republic by reviving a traumatic episode in order to underpin and enforce the political and religious consciousness of its citizens.

\section{TOPICAL POLITICS AND INTENDED AUDIENCE}

Aristotle's famous definition of literature as an art of 'mimesis' (which was well-known to Heinsius), ${ }^{17}$ draws attention to the ambivalent nature of literature in general and of history drama in particular, situated midway between imaginative universals and particulars in the external world: ${ }^{18}$

What we have said already makes it further clear that a poet's object is not to tell what actually happened but what could and would happen either probably or inevitably. The difference between an historian and a poet is not that one writes in prose and the other in verse-indeed the writings of Herodotus could be put into verse and yet would still be a kind of history, whether written in metre or not. The real difference is this, that one tells what happened and the other what might happen. For this reason poetry is something more scientific and serious than history, because poetry tends to give general truths while history gives particular facts. [...]

It is clear, then, from what we have said that the poet must be a 'maker' not of verses but of stories, since he is a poet in virtue of his 'representation,' and what he represents is action. Even supposing he represents what has actually happened, he is none the less a poet, for there is nothing to prevent some actual occurrences being the sort of thing that would probably or inevitably happen, and it is in virtue of that that he is their 'maker.'19

\footnotetext{
${ }^{17}$ Daniel Heinsius published his commentary on Aristotle, entitled De tragoediae constitutione, in 1611 .

${ }^{18}$ Lindenberger, Historical Drama, p. x.

19 Aristotle, Poetics 9.1-3; 9.9-10, transl. Hamilton Fyfe, pp. 35-37.
} 
Renaissance historiographers, basing their work on ancient models, were not only (nor even primarily) interested in historic particulars. They presented their public rather with a past that was 'universal' in the sense that present-day lessons could be conveyed: moral lessons, including-since politics were from the outset considered a part of ethics-political lessons. ${ }^{20}$ Classical Greek and Latin historiographies and tragedies-genres depicting the life of the high and mighty, and considered to teach philosophy by example-are interspersed with reflections on the arguments pro et contra different forms of government or the relationships between a ruler and his subjects. The political debates do not primarily have to be instigated by contemporary political issues. A discussion about the technical aspects of politics can also, or even simultaneously, be a matter of literary convention, a dialogue between the playwright and his sources.

However, when it comes to national history plays, authors often make full use of the opportunity to interact with their public and present their audience with topical political lessons. The production of national history dramas corresponded with a growing sense of patriotism within the Dutch Republic in the making. The portrayal of William of Orange as hero and martyr in the Orange plays served to build his image as a pater patriae, champion of the nation's liberty. Pieter Corneliszoon Hooft resorted to an earlier historic episode in his Geeraert van Velsen or even the Republic's dark mythological beginnings in his Baeto oft Oorsprong der Hollanderen, conceived as the Dutch Aeneid. In this play the mythological founding father Baeto is, like Virgil's Aeneas, urged to flee his native land and establish a future homeland for the Batavians in an uninhabited area between the Rhine, the Meuse and the Ocean. In a final scene interspersed with topical references, Baeto is granted the highest authority by Burgerhart, representative of the citizenry, with the approval of the soldiers and the religious leader Zegemond, acknowledging the supremacy of the State over the Church. Lifted upon his shield, Baeto swears an oath to govern henceforth in concordance with the noblest and best of citizens. Likewise, a civic humanist tendency instigated historiographies like Grotius's Liber de antiquitate reipublicae Bataviae (1610), legitimizing

${ }^{20}$ Cf. Aristotle's Politics (c. 340 B.C.), Cicero's De officiis (c. 45 B.C.), Erasmus's Institutio principis Christiani (1516), Lipsius's Politicorum sive civilis doctrinae libri $\operatorname{sex}(1589)$. 
the young Dutch Republic by stressing the nation's ancient tradition of independence, traced all the way back to Roman times, presenting the Batavian ancestors as equal confederates of the Roman empire. Grotius thus argued that the States had been in possession of the ultimate sovereignty since ancient Batavian times. Henceforth, if the sovereign appointed by the States does not govern and protect them properly, the States have the right to rise against him. ${ }^{21}$

Samuel Taylor Coleridge's thesis 'in order that a drama may be properly historical, it is necessary that it should be the history of the people to whom it is addressed ${ }^{22}$ touches the essence of national history plays. ${ }^{23}$ They need to represent history in such a way that it is recognized and/or picked up on by audiences as being 'their own' past. A telling illustration of this close tie between subject matter and audience is the captatio benevolentiae of Heinsius in his dedication of the Auriacus to the States of Holland and West Frisia:

Ego vero, illustrissimi Ordines, Tragoediam vobis offero meam; imo vestram: quod in ea meum est, trado vobis: quod vestrum est, ut gratum sit id quod offero, efficiet. Ita simul quod in reliquis Tragicis deplorari solet effugi, viamque mihi ad benevolentiam vestram praeparavi. ${ }^{24}$

I offer you, illustrious States, my tragedy, or rather yours: my part in it I hand over to you; your part in it will make sure that you like what I offer you. Thus I escape what is deplored in other tragedies, and pave my way to your benevolence.

Looking at the Dutch national history plays, the following tendencies apparently hold true: the more universal the content, the more familiar and politically pronounced the historic subject matter; the more distant the historic subject matter, the more topical (and thus more elaborately politically coloured) the content. Heinsius's Auriacus sive Libertas saucia ('William of Orange or Wounded Liberty') already shows its political message in the title; by contrast, the plot itself presents the downfall of a remarkably universal stoic hero, as will be discussed below. Conversely, when Hooft treats distant historical events, the topical political message is more fully elaborated throughout the

${ }^{21}$ See Van Gelderen, The Political Thought of The Dutch Revolt.

${ }_{22}$ Coleridge, The Literary Remains vol. 2, p. 142.

${ }_{23}$ Lindenberger, Historical Drama, pp. 6-8.

${ }^{24}$ Daniel Heinsius, Auriacus sive Libertas saucia, ed. Bloemendal, 1, p. 190. 
plot, and underlined by means that explicitly link the play's past with the public's present.

The close tie between a 'national' history play and its intended audience could provide the explanation to the question of why both authors claim that a play like Duym's Het moordadich stuck van Balthasar Gerards, begaen aen de doorluchtighen Prince van Oraignen (The Murder of the Illustrious Prince of Orange Committed by Balthasar Gerards), seemingly very different, is nevertheless an adaptation in the vernacular of Heinsius's Auriacus. Could the shifts in form and mode of the topical allusions have been dictated, at least in part, by a shift in the sociocultural field for which they were produced?

\section{Daniel Heinsius's Auriacus sive Libertas saucia (1602)}

Heinsius's decision to stage and publish the Auriacus in an attempt to establish his reputation as a scholar may be considered a daring enterprise, but was guaranteed to attract attention. At Leiden University, writing a play around the turn of the seventeenth century was not the safest and most modest career move. Since December 1595, theatrical performances were apparently suffering from a policy of determent. ${ }^{25}$ For all that, Heinsius and his friend Hugo Grotius, another rising star in Leiden, set out to secure a revival of ancient tragedy. Grotius wrote the biblical drama Adamus exul which was bound to please the Calvinist theologians. Heinsius took the clever decision to write a history drama commemorating and glorifying Prince William of Orange, the founding father of the University. ${ }^{26}$ As far as we know, Auriacus was the first play to appear on stage at the university after five years of an absence of drama performances-at least once, shortly after 25 January 1602, and perhaps even several times. ${ }^{27}$ Moreover, the debut was apparently lent additional lustre by the presence of the

${ }^{25}$ In 1595 decrees were issued stating that comedies or tragedies were only to be performed during holidays and with explicit permission of the rector magnificus and four assessores. In 1596, students proposing plays as part of a Bacchus celebration were told by the senate that performing tragedies or comedies was not in keeping with their dignity as members of the academy. Koppenol, Leids heelal, pp. 123-24.

${ }^{26}$ On the suggestion of William of Orange, Leiden University was founded by the States of Holland on 8 February 1575 as a reward for the town's brave resistance against the Spanish invaders, in order to serve as 'a staunch support and maintenance of the freedom and good lawful government of the country'.

${ }^{27}$ Heinsius, Auriacus sive Libertas saucia, ed. Bloemendal, 1, pp. 34-36. 
academic and political establishment, including one of the two sons of William (either Prince Maurits or Prince Frederic Henry), as Heinsius makes clear in his laudatory poem honouring the printed edition of Duym's Het moordadich Stuck from 1606:

In Balthasaris Gerardi execrandum facinus, a nobili viro Iacobo Duymio vernacula lingua conscriptum

Iberi scelus improbum dolusque,

Victori miserabilis Batavo,

Cum princeps populique patriaeque

Uno concidit impetitus ictu,

Nostro cum steterat prius cothurno,

Favit maxima Leida, favit ipsa

Totis plausibus annuens imago.

Favit Douza sui pater Lycei,

Favit maxima Caesaris propago,

Et Graiae columen Faber Camenae,

Et Grotius pia cura, Scriveriusque,

Et Graias Latiasque qui Camenas

Et Graias Latiasque amaret artes.

Muto caetera gens stetit theatro

Solis nescia gestibus doceri.

Vetat Duymius et vetans latere

Belgas protenus induit cothurno.

Belgae Belgia plausit, et 'quid', inquit,

'Rem decet populique patriaeque

Et patem populique patriaeque

Qui Belgiis periit, loqui Latinis?'

Stans pede in uno,

Daniel Heinsius ${ }^{28}$

On the loathsome crime of Balthasar Gerards, rendered by the nobleman Jacob Duym in the vernacular

When the scandalous crime and deceit of the Spaniard,

Dreadful for the victorious Batavian-

For the Prince of the people and the country

Was assaulted and struck down by one blow-,

Previously was staged in that tragedy of ours,

Leiden was highly pleased, even his spitting image ${ }^{29}$

was pleased, approving with warm applause.

${ }^{28}$ Duym, Het moordadich stuck, ed. Serrarens and Wijngaards, pp. 52-53.

${ }^{29}$ Apparently either Prince Maurits or Frederic Henry was present when the play was performed. 
Dousa, the father of his own University, ${ }^{30}$ was pleased.

The son of Caesar ${ }^{31}$ was highly pleased,

And Faber, ${ }^{32}$ pillar of the Greek Muse,

And gentle and thoughtful Grotius, and Scriverius, ${ }^{33}$

And all lovers of the Greek and Latin Muses,

And of the Greek and Latin arts.

The other people stood in a speechless theatre,

Not knowing how to understand mere gestures.

Duym resists, and resisting that it remained hidden,

He instantly dressed the Dutchman in the tragic boot.

The Dutch country applauded for the Dutch and said: 'Why

Does it befit an affair of the citizens and the country

And the father of the citizens and the country,

Who died for the Dutch, to speak for the Latins?'

In less than no time,

Daniel Heinsius.'

Heinsius stresses the different target groups of his Orange play and Duym's translation in the vernacular. Even so the play, meant for a humanist audience well-versed in Greek and Latin literature, was apparently also attended by people of more modest education, unable to decipher Latin, and thus, according to Heinsius, unable to understand the play merely on the basis of the body language of the actors. Heinsius, while stressing the success of his own play, gives Duym credit for suitably unlocking the play about the founding father of the Dutch nation for a Dutch-speaking audience.

The play not only enjoyed one or more performances at Leiden University, but was also published in a printed edition, issued with the support of all leading humanists of the academy, according to the abundant praise in a great variety of liminal poems. ${ }^{34}$ In the dedication of the play to the States of Holland and West Frisia, Heinsius makes an effort to stress the novelty of the genre: while the Greek and Roman genre of tragedy is the most dignified of all, Heinsius distances himself

${ }^{30}$ Janus Dousa was the first curator of the Leiden University.

${ }^{31}$ Josephus Justus Scaliger, the son of Julius Caesar Scaliger.

${ }^{32}$ Bonaventura Vulcanius, professor of Greek at Leiden University.

${ }_{33}$ The historian and poet Petrus Scriverius wrote a chronicle of Holland in the vernacular, Beschrijvinghe van Out Batavien, mitsgaders d'Afkomst ende historie der graven van Holland, Zeeland ende Vrieslandt (1612), as a follow-up to a history of the Counts of Holland by Jacob Duym. In 1616 he edited the Nederduitsche gedichten by Daniel Heinsius.

${ }^{34}$ Josephus Justus Scaliger, Hugo Grotius and Janus Dousa (among others) honoured the printed publication of Auriacus with laudatory poems. 
from the 'idle and foolish' stories of most ancient tragedies, derived from classical mythology. ${ }^{35}$ In Antiquity, tragedy was especially valued for the lessons it could provide in sapientia moralis civilisque ('moral and political wisdom'). Accordingly, Heinsius has found worthy subject matter in the recent history of Holland. ${ }^{36}$

The well-wrought tragedy is modelled on those attributed to Seneca, speaking louder in words than in action, full of ethical contemplations. As such, Heinsius's Auriacus is a didactic drama, in the tradition of the humanist school plays. Moreover, the moral lessons in the history play are in line with the important function attached to the study of history in the humanist school curriculum, which was considered to teach ethics by example. ${ }^{37}$ The Auriacus conveys a stoic message. Following Seneca, Heinsius makes William of Orange out to be a true stoic hero, facing his inevitable destiny with superhuman constancy and fortitude. ${ }^{38}$ Thus, in comparison with subsequent Orange plays, Auriacus is remarkably timeless.

However, the universal content does not prevent topicality from playing its part. In fact, the ancient outlook and the topical political message, reinforcing each other, must have been a very natural and effective combination to Heinsius and his humanist public. When Heinsius set out to imitate and emulate ancient tragedy in his own time and place, treating the trials and tribulations of the high and mighty, the combination of the 'royal' genre of tragedy with 'Orange, your leader' was an obvious choice, as he made clear in his dedication to the States of Holland and West Frisia. Conversely, the classical mould might be considered the most impressive way to bring home a proud patriotic message to his humanist audience, well-trained in the literary code of the ancients. Heinsius wrote his history play at a time that the Republic prospered and the princes of Orange scored

\footnotetext{
${ }^{35}$ As early as Roman times, tragedies about (near-)contemporary Roman history were written, the so-called fabulae praetextae. The pseudo-Senecan Octavia is the only extant complete ancient Latin history play. The first Renaissance humanist play, Ecerinis (1315) by Albertino Mussato, inspired by the discovery of a manuscript with Seneca's tragedies, is a history play in Senecan tradition. However, in the dedication of Auriacus Heinsius is referring to the mythological subgenre which was in his time and place most commonly understood as a synonym for ancient tragedy; ethical motives had prompted Dutch humanist educators since the beginning of the sixteenth century to resort to biblical tragedies in ancient fashion, but with a scriptural subject matter.

${ }^{36}$ Heinsius, Auriacus sive Libertas saucia, ed. Bloemendal, 1, p. 190.

${ }^{37}$ Groenland, 'Tijdloze geschiedenislessen'.

${ }^{38}$ Bloemendal, 'Willem van Oranje: Een Hercules op Leidse planken'.
} 
successes on the battlefield against the Spanish 'oppressor'. Heinsius target group, the academic community in Leiden, was certainly not led astray by the antiquated mould in which the contemporary lesson was cast. The terms of praise that the humanist scholar Josephus Justus Scaliger used to summarize the play's merits leave no doubt that Heinsius succeeded in bringing home to his audience a topical political message: 'Thanks to the lofty verses of Heinsius, the death that is a unique source of shame to you[, Spaniard], amounts for the Prince of Nassau to eternal life'. ${ }^{39}$

In this respect, a striking and significant last minute-change was made to the printed version of the play, right in the middle of the production process. After the text was printed, but before the leaves were bound, a scene of two pages was added. ${ }^{40}$ Prince Maurits-William's son who had been only eighteen years old at the time of the murder but had developed another eighteen years later into the military leader of the Dutch Revolt-enters the scene and delivers a hopeful speech, promising the Dutch nation in despair that his father's death will be avenged. In the preface to the reader, who was sure to have acquired an adequate level of humanist learning, Heinsius made an effort to justify the insertion of this final monologue. Assuring the reader that it was not at his behest that Prince Maurits played a part in the play, Heinsius refers to 'persons of consequence'-presumably representatives from the university board or the government, which were to lend support to the play's performance-exerting pressure on him to pronounce his loyalty to the Stadtholder in a more straightforward fashion..$^{41}$ Of course, Heinsius did not object to political propaganda as such. As noted above, like all humanists he was deeply convinced that literature should instil moral and political lessons in readers and spectators. Heinsius's objection was dictated by his profound knowledge of ancient poetics reflected in his Aristotle commentary De tragoedia constitutione (1611). He was convinced that a playwright following the ancient tradition had to keep the unity of time and place. ${ }^{42}$ Since

\footnotetext{
39 'Grandiloquis Heynsi numeris, quae dedecus una est / Mors tibi, Nassovio vita perennis erit'. Heinsius, Auriacus sive Libertas saucia, ed. Bloemendal, 1, pp. 208-09.

${ }_{40}$ The word Finis is printed after the original ending, the monologue of Libertas, and the new concluding monologue by Maurits is set in a different typography. Heinsius, Auriacus sive Libertas saucia, ed. Bloemendal, 1, p. 130.

${ }^{41}$ For this interpretation see Groenland, 'Predicting the Present'.

${ }^{42}$ Cf. Meter, De literaire theorieën van Daniël Heinsius, pp. 583, 586; Scaliger, Poetices libri septem, 3.96, ed. Deitz, 3, pp. 28.22-30.24.
} 
Maurits had not been present in Delft that fatal day, Heinsius could not give him a part in the play that represented the murder of his father William. Apparently by way of compromise, Heinsius did ultimately come up with a solution. He put the Prince on stage, but found a way to adhere to his poetical principles at the same time. In keeping with humanist tradition Prince Maurits became a deus ex machina, the divinity falling out of the sky at the end of an ancient play, proclaiming the subsequent course of events. ${ }^{43}$ The monologue not only made it into the printed edition of the play. In the preface to the reader, Heinsius added that he would only put the monologue in print when it had proven its worth during the performance. Thus from the last minute-revision in print we may well conclude that it received a warm welcome from the audience. ${ }^{44}$

Prince Maurits's final monologue ensured that the topical political message was not lost on any of the spectators, whatever the nature and level of their education. Moreover, in the penultimate scene-which had been the original end of the play-the audience had been confronted with utter despair and abandonment. They had been watching the ill-fated departure of both the assassinated William of Orange and the Liberty of the Republic from the stage, from 'the civilized world', and ultimately-reminiscent of a traumatic episode that was still fresh in their memory-from them. In the revised version, with the present leader appearing on stage as the heaven-sent saviour of the Republic, the sentiments aroused were directly released and steered into a definite political direction.

As Heinsius wanted to make clear in the preface to the reader, he had added Maurits's monologue not without demur. Ironically, following the lead of Auriacus, the insertion of a final prophecy, linking the play's past to the present of its public, became a popular device among Dutch playwrights. Vernacular playwrights like Duym, Van Hogendorp, Hooft and Vondel readily recognized the opportunity to stress the topical interest of their history play and reach out to their

${ }^{43}$ Aristotle, Poetica 1454 b2-5.

${ }^{44}$ Source material suggests that Heinsius composed his Auriacus in the autumn of 1601. The performance took place shortly after 25 January 1602 . The printed edition appeared before 8 May 1602. We may induce that the original version of Auriacus, without the final monologue by Prince Maurits, was already in print before the performance. After the extended closing scene had proved its success on stage, two pages were added before the leaves were bound. Cf. Heinsius, Auriacus sive Libertas saucia, ed. Bloemendal, 1, pp. 33-36. 
audiences. ${ }^{45}$ This manifold reception and the lasting fame of the prediction by the River Vecht in Hooft's Geeraerdt van Velsen (1613), or that of the Archangel Raphael in Vondel's Gysbrecht van Aemstel (1638), even raises the question of whether Heinsius's initiative to promote the history play would have met with the same success had he not granted Prince Maurits the last word in his Auriacus.

\section{Jacob Duym and his Ghedenck-boeck Containing HET MOORDADICH STUCK (1606)}

'Of all authors that have played a significant part in the development from rhetorician to Renaissance drama, Jacob Duym has received least attention. The great playwrights have their own monographs by now, except for Duym, with no less than twelve plays one of the most productive writers of his generation. ${ }^{46}$ So proclaims Koppenol in a relatively recent first step to redirect attention to Duym. The last comprehensive study dedicated to the dramatist dates from more than a century ago. ${ }^{47}$

Born in Leuven of noble family, Jacob Duym obtained his university degree at the Faculty of Law. Initially he established himself as a lawyer and, after having been given various public duties, became one of the town's dignitaries. In 1576 he made a career change and joined the military, at first serving as a captain under Don John of Austria, Philip II's Governor-General of the Low Countries. However, in 1584 Duym resurfaced on the rebels' side, commanding infantry in defence of Fort Lillo near Antwerp against the Duke of Parma's troops. Resistance was futile: Parma had Antwerp firmly in his grasp and Duym was captured, on his own account on the battlefield, but according to a town historiographer on his country estate in the presence of his wife and children. After nearly two years of imprisonment Duym managed to buy himself out of the army following the Fall of Antwerp. Nevertheless, physically disabled for life, Duym escaped the war. Fleeing from

\footnotetext{
${ }^{45}$ For a discussion of the final prophecies in Duym's Moordadich Stuck, Van Hogendorp's Treur-spel van de moordt and Geeraerdt van Velsen and Baeto by Hooft, as well as their connection with Heinsius's Auriacus, see Groenland, 'Predicting the present.'

${ }^{46}$ Koppenol, 'Jacob Duym en de Leidse rederijkers'.

${ }^{47}$ Poll, Over de tooneelspelen van den Leidschen rederijker Jacob Duym.
} 
the Spanish Low Countries, he arrived in Leiden in 1586. He remained a fervent supporter of the House of Orange.

An application for the staging of two plays to the town council of Leiden dating from 1588 is the first evidence of Duym's activities as a playwright. Two years later the municipality honoured a request by Flemish refugees to establish their own chamber of rhetoric, separate from the existing chamber 'De Witte Acoleyen'. Up to now it was assumed that Duym was attached to the Flemish chamber 'd'Orainge Lelie' right from the start, although his name is absent from the members' list of 1590. Koppenol, however, argues convincingly-on the basis of (among other things) the act of Duym's appointment in 1591 as Emperor of the chamber-that only then was Duym pushed forward as an external candidate by the town council. The municipality wanted to restore order after the church council had complained about de misbruycken die in eenige speelen zouden mogen zyn gepleecht ('malpractices that seemingly have been committed in some plays'). ${ }^{48}$ From 1592 until 1600, Duym's literary activities are well documented. 'D'Orainge Lelie' produced Duym's Spieghel der rechtvoordering ('The Mirror of Legal Claim', 1592), Spieghel der Eerbaerheyt ('The Mirror of Decency', 1595), Spieghel der liefde ('The Mirror of Love', 1596). Den spieghel der Getrouwicheyt ('The Mirror of Fidelity', 1600) and Den Spieghel des hoogmoets ('The Mirror of Pride', 1600). The last work is an adaptation of Seneca's Troades. In 1600 these five plays and Den Spieghel der Reynicheyt ('The Mirror of Chastity') were published in one volume: Duym's Spiegelboeck ('The Book of Mirrors').

Duym and his plays then seem to have disappeared from the scene of the Flemish chamber. Did Duym and 'd'Oraigne Lelie' sever relations? From then on Duym's publications show a thematic change and an expansion of his network. Compared to his Spiegelboeck, the liminal poetry in his Ghedenck-boeck of 1606, a collection of six new plays, is written by a greater number of humanists from Leiden University, members of the chamber of rhetoric 'De Witte Acoleyen' instead of 'd'Oraigne Lelie', and Carel van Mander from Haarlem and his circle. The six new plays in the Ghedenck-boeck ('The Book of Memory') represent near-contemporary episodes of the Dutch Revolt, recalling the atrocities committed by the Spaniards and the hardship endured by, and the achievements of, the Princes of Orange: the

\footnotetext{
${ }^{48}$ Koppenol, 'Jacob Duym en de Leidse rederijkers', p. 15.
} 
capture of Breda, the siege and relief of Leiden, the battle of Antwerp, and also, following Heinsius's Auriacus, the assassination of William the Silent.

The topical message of Duym's 'Book of Memory' as a whole is expressed in the aphoristic title of one of the plays: Een bewys dat beter is eenen goeden crijgh, dan eenen gheveynsden peys ('Proof That a Fair Battle Beats a Fake Peace'). Duym wanted to (re)confront his audience with all the hardship they suffered at the hands of a relentless and treacherous Spanish enemy. Het moordadich stuck neatly fitted in with the overall purpose of the book, since Duym looked to the Prince's sons to carry on the war in the name of their father. As Duym puts it in the dedication of Het moordadich Stuck to Frederick Henry: 'niet twijfelende uwe Excellentie soo 't alreede ghenoegh heft ghebleken, is bereyd om dese moord aen den Heere Prince voorsz begaen tot den uytersten te wreken, ende Spaingnaerden den rechten loon die sy wel hebben verdient te gheven' ('not doubting that your Excellency, for this became already sufficiently clear, is willing to avenge this murder inflicted on the aforementioned Prince to the extreme, and to give the Spaniards the just reward that serves them right').

Does the militant message of Duym's play justify the conclusion that Duym was 'representing the anti-peace movement at a critical moment in Dutch history, when Johan van Oldenbarnevelt began to advocate peace deliberately and openly" ${ }^{49}$ Can we even go as far as to infer that 'Duym was trying to influence the political decision-making process, by dedicating the 'Book of Memory' as a whole to Prince Maurice and, tellingly, Een bewys dat beter is eenen goeden crijgh, dan eenen gheveynsden peys to Johan van Oldenbarnevelt'?50 That is to say, are we to infer that Duym did articulate the allegedly bellicose vox populi, and dedicated his play to Oldenbarnevelt in the hope of convincing a supposed peace-loving leader? I am afraid that scholars, blinded by the later course of events, may, in this case, have jumped to conclusions too hastily.

From 1606 onwards the young Dutch Republic would be facing an increasing polarization between the military leader Prince Maurits and Grand Pensionary Johan van Oldenbarnevelt. In the course of that year negotiations started which would lead to the Twelve-Years'

${ }^{49}$ Wijngaards, 'De zgn. Oranjestukken en hun publiek', p. 127.

${ }^{50}$ Duits, Van Bartholomeusnacht tot Bataafse opstand, p. 100. 
Truce with Spain in 1609. However, the dedication of Het moordadich stuck is, like the dedications of all other five plays, dated 1 January 1606. The Ghedenck-boeck, with an imprint by H.L. van Haestens in Leiden in 1606 , was probably published shortly after. ${ }^{51}$ The six plays must have been in progress well before that time. While Oldenbarnevelt may privately have been pondering peace earlier, up until the autumn of 1606 the States, headed by the Grand Pensionary, categorically rejected every direct or indirect proposition of peace. ${ }^{52}$ The population was, however, feeling the full weight of the costs of a war which after almost four decades was losing its idealistic zeal and progress. The golden days of prosperity and military successes seemed to have passed, and support from former allies like England and France began to waver. ${ }^{53}$ It is likely that Duym's pro-war plays fought against certain popular sentiments while siding with the official policy of the leading men in the Republic, Oldenbarnevelt and Maurits. It would take until 1607 before the flow of pamphlets against the negotiated peace burst upon the scene. All the same, the question of 'treaty or no treaty' was not an invention dating from the years leading up to 1609 . The title of Duym's most explicit pro-war play, Een bewys dat beter is eenen goeden crijgh, dan eenen gheveynsden peys, may have been suggested by the assignment for a rhetorician contest in Leiden as early as 1596, where a refrein (the Dutch ballade) was requested with the stokregel (the Dutch refrain) Voor een beveynsde paeys, een rechte crijch te prijsen is ('More than a fake peace a just war is to be praised'). ${ }^{54}$

A closer look at the latter play, which polemically states 'Proof that a fair battle is to be preferred above a fake peace' and which is dedicated to Oldenbarnevelt, confirms the hypothesis that Duym's play, meant in support of the Grand Pensionary and the States, set out to counter inclinations to peace negotiations among the population. The play is a comedy situated in the year 1600, a memorable date because it was in that year that the battle of Nieuwpoort occurred. This hard-fought and fruitless victory of the Dutch army represents the first significant rift in the relation between Maurice, who had stated his reservations

\footnotetext{
51 A copy of another play in the Ghedenck-boeck, Het innemen des Casteels van Breda, was sent to the municipality of Breda with a letter dated 6 March 1606. Poll, Over de tooneelspelen van den Leidschen rederijker Jacob Duym, 64.

${ }^{52}$ Van Eysinga, De wording van het Twaalfjarig Bestand, pp. 76-77.

53 Van Deursen, Maurits van Nassau, pp. 201-02.

54 Poll, Over de tooneelspelen van den Leidschen rederijker Jacob Duym, p. 80.
} 
beforehand, and Oldenbarnevelt, who had influenced the States to order the expedition. However, in his play Duym does not take his public to the battlefield, but (in an allegorical representation) to the negotiation table instead, where he assigns the hero's part to Oldenbarnevelt. Duym recalls peace offerings in $1600^{55}$ for the steadfastness of the States under the guidance of the Grand Pensionary; they were united in countering the dishonest scheme of the Spaniards which was only meant to sow discord:

$\mathrm{Al}$ het voorgaende wel aanmerckende ende ernstelijcken insiende, Edele, Erntfeste, Wijze, Voorsienighe heer heb ik goet ghevonden Comedische wijse in myn Ghedenck-Boeck te voeghen, hoe dees Landen inden jaer sestienhondert door verscheyden Ghesanten van veel Potentaten tot Vrede zijn vermaent gheweest, ende daer naer uyt Braband, dan door eenen Coopman, dan door een Advocaet zijn gheterght geweest, om haer ooren tot den vrede te keeren, altijd hopende dat soo sij den geveynsden vrede niet en wilden aengaen dat door dit gherucht van vrede tenminste onder de vereenichde Landen eenighen twist ofte tweedracht soude op staen, maer de goedighe God gaf de Moghende Heeren Staten sulck een standvastich gemoed, dat zy het Spaensch voornemen wel wetende, in plaets van vrede te maken liever onderlinghen verdraghen hebben haren Vyand te water ende te lande selver te soecken, ende haer van ghelt en volck beter versien hebben goeden Crijgh te voeren. Ende sal in dese Comedie de principaelste personagie zijn den Trouwen raed, dien de Vereenichde Provincien sullen soecken te volghen, ende alsoo uwe warachtich is den voornaemsten Raed des Lands, ende Advocaet van Holland, en heb ick desen mijnen arbeyd niemand bequamer weten toe te eijghenen, als uwe E. wiens trouwe raed hoe noodich ende profitelick hy dickmael gheweest is, ghenoech beproeft is. ${ }^{56}$

Acknowledging the aforementioned and taking it seriously, noble, honourable, wise and prudent lord, I chose to include in comic fashion in my Book of Memory, how these lands in 1600 were urged towards peace by various delegates from many rulers, and pressured thereafter from Brabant, first by a merchant, then by a lawyer, to lend their ears to peace, invariably in the hope that if these lands would not enter into the fake peace, that by this rumour of peace at least some strife or discord would rise among the united provinces. However the good Lord gave the mighty Lords of the States such a constant spirit that they, aware of the Spanish intentions, instead of making peace have rather endured to seek out their enemy at sea and on land, and provided money and manpower

${ }^{55}$ See Den Tex, Oldenbarnevelt 2: Oorlog 1588-1609, pp. 374-80.

${ }_{56}$ Jacob Duym, Een bewys dat beter is eenen goeden crijgh dan eenen gheveynsden peys (Leiden: Henrick Lodowijcxszoon van Haestens, 1606), A iij $\mathrm{r}^{\circ}-\mathrm{v}^{\circ}$. 
to fight a fair war. In this comedy the principal part will be played by the loyal Counsellor, whom the United Provinces will seek to follow, and since you are truly the prime Councillor of the Land, and Advocate of Holland, I could not have thought of a more appropriate dedicatee than Your Honour, whose loyal council, as often as it has proved necessary and profitable, was sufficiently put to the test.

Again, in the preface to 'the benevolent reader', Duym tries to elicit the goodwill of his fellow countrymen for seemingly unpopular, burdensome consequences of the politics of the war. Presenting himself as one of the people, he speaks as counsel for the defence of the official political line:

Wy bekennen wel datter veel gegeven word ende dat de lasten des oorlooghs groot zijn, maer wat ist daer moet ghegheven zijn, willen wij Goodes woord de vrijheyd des Landes ende ons eyghen rust behouden, beter ist grootelickx te gheven ende noch wat te behouwen, dan dat wy al verliesen dat wy hebben, ende in groot bedwanck der consciëntie sitten, ende weer naer galgen, raderen ende brand-staken gheleyd worden: door het geven en bevrijen wy niet alleen ons selven maer oock onse naecomelinghen, ende behouden het leven van soo veel duysent sielen die noch op verscheyden plaetsen onder het cruys sitten, ende die sy noch laten leven soo lang als sy niet heel meester en zijn, ende voor besluyt reden word hier vertoont dat wij beter de helft van al onse middelen gaven dan dat wy in de eewighe slavernije van de Spaingnaerden en haren aenhanck souden gheraken. ${ }^{57}$

We realize the many contributions that are made and the great burdens that are imposed by the war, but we have to make these sacrifices if we wish to maintain God's word, the freedom of the country and our own peace and quiet; it is better to give abundantly and to maintain something than to loose all that we have and to be conscience-stricken and led once again to gallows, wheels and stakes. Through sacrifice we free not only ourselves but also our descendants, and preserve the life of so many thousands of souls who suffer persecution and are only kept alive as long as they are not completely in control. By way of conclusion it is argued that we are better off sacrificing half our resources than living in eternal slavery to the Spaniards and their supporters.

The so-called 'people's man' Duym, ${ }^{58}$ justifying the official policy of the powers that be against certain popular sentiments, may have been less of a populist than has been presumed up to now. Even though Duym presents himself as a spokesperson by using a collective 'wy'

${ }_{57}$ Ibidem, $\mathrm{A}$ iv v ${ }^{\circ}$.

58 See n. 6. 
(we) in the above preface, he only addresses the Protestant community (approximately $20 \%$ of the population), excluding the Roman Catholics (who probably still formed the majority).

As for a performance of Het moordadich Stuck, after Duym's possible estrangement from the chamber of rhetoric 'd'Oraigne Lelie', the chamber of rhetoric 'De Witte Acoleyen' would have been the obvious place to stage the plays in the Ghedenck-boeck. No performances of any of the six plays are documented, but we must be careful to base conclusions on this ex silentio. Koppenol remarks 'as much information as we have about performances in the Leiden chambers of rhetoric in the last decade of the sixteenth century, so rare are the data for the next ten years. Quests for titles in the town archives were to no avail'..$^{59}$

\section{Het MOORDADich STUCK as a translation of AuRIacus}

A man of letters in Leiden like Duym could very well have been present at the performance of Heinsius's Auriacus. As his university education suggests and both his adaptation of Seneca's Troades and Heinsius's Auriacus confirm, Duym was sufficiently schooled in Latin to master the text he emphatically identified as the source text of Het moordadich Stuck:

Tot den Leser.

Hier sal u goetwillighe Leser voor ghestelt worden het leelijck ende moordadich stuck van Balthasar Gerards begaen aen den persoon van den Prince van Oraignen, het welck over sommighe jaeren is in den Latine ghesteld gheweest, bij den Hoogh Vermaerden Professoor ende Poet Daniel Hensio, in zijnen Auriaco, Die het selfde seer fray ghevonden ende met veel schoone Poetische spreucken verciert heeft, des en begheeren wij die sonderlinghe eer die hem toecomt gheensins te verminderen, maer alsoo onse Nederdutysche sprake soo veel wijdloopighe spreucken niet verdraghen en mach, ende dat die selvighe niet bequamelijck en konnen van woorde tot woorde over gheset worden, soo hebben wij hem ter eeren nochtans den selven Auriacum ghevolght, ende sommighe Personagien ghevoechelick naer onsen sin verandert. ${ }^{60}$

To the reader.

${ }^{59}$ Johan Koppenol, 'Jacob Duym en de Leidse rederijkers'.

${ }^{60}$ Duym, Het moordadich stuck, ed. Serrarens and Wijngaards, p. 62. 
Here will be presented to you, benevolent reader, the atrocious and murderous act of Balthasar Gerards, inflicted upon the person of the Prince of Orange, which has been formulated in Latin some years ago by the highly renowned professor and poet Daniel Heinsius in his Auriacus. He made the same into a very fine composition and adorned it with a lot of very beautiful poetic sayings. Hence we do not wish to detract in any way from the exceptional honour he deserves, but since our Dutch language does not tolerate so many long-winded sayings and they could not be adequately translated word for word, we nevertheless have followed, in his honour, this Auriacus and changed some characters as we judged fit and proper.'

Serrarens and Wijngaards discuss the relationship between Duym's and Heinsius's plays at great length in their edition of Het moordadich stuck. As indicated above ${ }^{61}$ on account of the direct link Duym made between his own play and the Auriacus, they accuse him of establishing his identity 'with a false passport', hiding his true intent, presumably the wish to impose his political opinion on 'the mass of people'. In their words, Duym succeeded in 'bringing the historic event much closer to the common man'. By contrast Heinsius is accused of having 'cast his thoughts in a mould that alienated 99\% of his fellow citizens' ${ }^{62}$ Consequently, Duym is charged with untruthfulness for identifying Heinsius as his source text. Besides, Heinsius has to pay the price for sanctioning this claim in his liminal poem: 'Apparently Heinsius was still too egocentric to read Het moordadich stuck objectively in its current context. Did perhaps a certain bookishness prevent Heinsius from experiencing its topicality?'63

However, a comparison of Het moordadich stuck and Auriacus shows how Heinsius is in part followed closely, by way of direct translations or strong similarity in content, whereas elsewhere the translation or adaptation is quite free. ${ }^{64}$ The most important changes can be summed up as follows:

- The length of the drama (Auriacus 2171 verses, Het moordadich stuck 1342 verses) is reduced by $38 \%$.

61 P. $1 \#$.

62 Duym, Het moordadich stuck, ed. Serrarens and Wijngaards, pp. 45-50. See also Poll, Over de tooneelspelen van den Leidschen rederijker Jacob Duym, pp. 127-46 and Wijngaards, 'De zgn. Oranjestukken en hun publiek'.

${ }_{63}$ Duym, Het moordadich stuck, ed. Serrarens and Wijngaards, p. 52.

${ }^{64}$ Ibidem, pp. $14 \mathrm{ff}$. 
- Duym adds a prologue and epilogue spoken by the Dichtstelder ('Author') which emphasize the link with the public's present. Regardless of ancient poetics the prediction of Maurits is part of the plot, breaking the unities of time and place.

- Duym reduces the epic digressions, comparisons, metaphors and sententious sayings, as he stated in his preface.

- Some personages have undergone a metamorphosis. In his preface, Duym states in the same breath that, just as he could not take over the Latin sayings in Dutch, he also needed to change some of the characters as he saw fit. However much this may seem a comparison between apples and oranges, an example clarifies the connection. In Auriacus a raging Inquisitio, carrying a torch and a cup of human blood, is accompanied by a classic threesome: the Furies, who don't deliver any lines but according to a rare stage direction of Heinsius should have an apparent ancient look and feel. ${ }^{65}$ Duym translates these ancient characters into three contemporary personifications, meant to enter the stage in costumes that appealed to the public's terror and disgust: Spaenschen Raed ('Spanish Council'), Heymelijken Haed ('Hidden Hatred') and Bloed-dorst ('Bloodthirstiness'). The first two are to be dressed like Spaniards, clothed in black trousers and a coat with a Spanish collar, Bloodthirstiness stained with blood, Inquisition herself in a Jesuit cloak and holding a rod. Later on in the play, Duym makes these three personifications return as sinnekens in the tradition of the rhetoricians. ${ }^{66}$

- The choruses have been amplified and made even more recognizable and up-to-date. Heinsius had already inserted a rather emotional chorus of Flemish refugees, saluting their new country, who were filled with melancholy and hope for the future, in a classical ode that compares a rural existence to city life. Duym expands the choir to (explicitly) 'many' Flemish refugees, divided into three social classes and dressed accordingly. Furthermore, the war veteran from Leuven adds a chorus of many refugees from Brabant, again in three social classes, commemorating the fall of Antwerp and their looted homeland.

\footnotetext{
${ }^{65}$ Following Heinsius, the Furies should look like their depictions by contemporary painters or on ancient coins, inscriptions and medallions. Heinsius, Auriacus sive Libertas saucia, ed. Bloemendal, 1, pp. 244-45.

${ }^{66} \mathrm{Cf}$. Hummelen, De sinnekens in het rederijkersdrama.
} 
Surveying the most significant changes made by Duym, the claim made by the playwright himself and sanctioned by Heinsius that Het moordadich stuck is a 'translation' of Auriacus goes a long way, given the translation practices of the time and the transfer that had to be made from one language and literary code to another. Significantly, Duym's translation of Seneca's Troades shows the same adaptation of the sententious classical style to a less verbose vernacular tradition, as well as the tendency to conform to common features of rhetorician drama by adding a prologue, epilogue and interludes spoken by the Dichtstelder. ${ }^{67}$ Likewise, in a recent paper Van Gemert, comparing related poems composed by Heinsius in a Latin and vernacular fashion, found: 'Die Gegenüberstellung beider Gedichte mag gezeigt haben, daß Heinsius bemüht war, einer offensichtlich präsupponierten Eigenständigkeit niederländischer Dichtung gegenüber der lateinischen gerecht $\mathrm{zu}$ werden. Für ihn sind beide Bereiche, gerade auch bei aller thematischen Nähe, klar getrennt. Daß hier gelehrte Anspielungen und Mythologisches einen anderen Stellenwert innehatten, liegt nahe'. ${ }^{68}$

Duym translates Heinsius's Latin Orange play, composed according to the conventions and form of ancient literarure, to the vernacular language and tradition of the rhetoricians. Both authors conform to the literary code suitable for the language and tradition in which their Orange play operates. Thus while Heinsius's Auriacus presents himself in an opening monologue in the tradition of classical freedom fighters like Brutus, Harmodius and Aristogiton, Duym's Prins van Oraignen places his struggle for independence more directly in the recent history of the Dutch revolt. Nonetheless both authors refer to the atrocities committed by the Spanish tyrant in order to justify the rebellion led by William of Orange. Consequently the conclusion of Serrarens and Wijngaards-that Heinsius's stoic, detached hero facing his Destiny with superhuman fortitude must have appealed to a smaller audience than Duym's haunted, more human, passionate and sympathetic Prince-is premature. And there is no reason whatsoever to assume that Duym would have wanted to distance himself openly from the grand theatrical gestures and bragging voice of the student

\footnotetext{
${ }^{67}$ Poll, Over de tooneelspelen van den Leidschen rederijker Jacob Duym, pp. 124-27.

${ }^{68}$ Van Gemert, 'Zum Verhältnis neulateinischer und muttersprachlicher Dichtung bei Daniel Heinsius', p. 311.
} 
from Leiden University playing the leading part, as Serrarens and Wijngaards picture the representation of Auriacus. ${ }^{69}$ On the contrary, both Heinsius and Duym had done the best they could, within their language and their literary system and for their own target audience, to honour the memory of William of Orange and instil in the spectators and readers patriotic sentiments and loyalty towards the Prince's heirs, Maurits and Prince Frederick Henry. Thus Heinsius, writing for a humanist public, had given the Pater patriae the stature of an ancient hero and compared his motives and his fortitude to those of classic freedom fighters. Duym however, keen to translate this ancient parallel adequately to a public accustomed to the conventions of rhetorician drama, had stripped the Prince of all these classic references and put him in a guise that was more recognizable to his audience.

\section{Conclusion}

The close interrelationship between the plays of Heinsius and Duym claimed by both playwrights cannot be disposed of as the untruthfulness of the rhetorician and snobbism of the humanist, but is confirmed on closer scrutiny. Heinsius's Auriacus was a national history drama appealing to the patriotic feelings of a humanist audience. Heinsius's wish to imitate and emulate the classical playwrights entailed the elevation of the Dutch Republic to the level of Greece and Rome. While casting national subject matter in the mould of ancient tragedy, the tribute to William of Orange as pater patriae served Heinsius well to entice the academic and political establishment and gain the necessary support for his effort to revive ancient tragedy. It was precisely in the form of the classical literary mould that the topical political moral took shape, prompting the portrayal of William of Orange as a universal stoic hero. Duym, when composing the rhetorician plays in his bellicose Book of Memory on the atrocities and treacheries committed by the Spanish enemy, recognized the degree to which a translation of Heinsius's Auriacus would suit his purpose. Transplanting Heinsius's ancient intertext, which had clearly expressed a patriotic topical message to the humanist audience of the Auriacus, Duym resorts to a literary language and visual means that are more familiar to the intended

\footnotetext{
${ }^{69}$ Duym, Het moordadich stuck, ed. Serrarens and Wijngaards, p. 30.
} 
audience of his rhetorician drama. For both authors the topical allusions are a means of connecting to their different audiences, a means of enticing them into taking an interest in their plays and inviting commitment to its subject matter. In playing to their respective audiences they play with their public's opinions.

While aiming at different audiences, composing in different coexisting literary systems, Duym's adaptation of Heinsius, 'sanctioned' in a liminal poem for Het moordadich stuck by the latter, also testifies to the interplay between the Latin and vernacular culture-interplay on the level of the authors, and even to a certain extent, as we could read in Heinsius's liminal poem, on the level of the audience: apparently, non-Latin spectators were present at the performance of the Auriacus, although Heinsius expresses his reservations as to their capacity to grasp the content of his play, pervaded as it was with an academic humanism demanding an advanced level of Latin education. It is particularly for this part of the audience that, according to our interpretation, the authorities demanded the addition of the Maurits scene at the end of the play, underlining the topical political message in a way that, if judging only by the appearance of the Stadtholder onstage, was not to be misunderstood. While the target reader of Het moordadich stuck is precisely this 'non-Latin' literate citizen, more familiar with the conventions of rhetorician drama and not required to have any knowledge of its model Auriacus, both Duym and Heinsius hasten to inform him, in the preliminary pages, of the close connection between their plays. Both authors could expect to gain literary, cultural and social capital by their affiliation: Heinsius because the example of his Auriacus had been imitated, Duym for all the reflected glory of the academic enterprise of his humanist colleague.

Which author was more successful in driving home his message? Did Duym reach a larger, less privileged audience than his humanist predecessor, as has been the general assumption up to now? Heinsius, anxious to establish his name at Leiden University, aspired to nothing less than the resuscitation of ancient tragedy. In the short term, he achieved his goal by receiving permission to stage his tribute to the university's founding father in the presence of all leading scholars of the academy and even Prince Maurits or Frederick Henry. Equally, the printed version of the play received accolades in the form of lavish declarations of sympathy from the Leiden humanists. In the long run, other men of letters followed Heinsius's innovative lead. Although the 
humanist would probably be the first to point out all the ancient poetic rules defied in the history plays written in his footsteps, the Auriacus did function as the standard-bearer of the genre of national history drama that would prosper for years to come. Duym on the other hand cannot be designated the voice of the people, who were generally weighed down by the heavy toll they paid for a long-lasting war that was losing its urgency at the beginning of the seventeenth century. From the existing evidence, it rather looks as if Duym expressed the official policy of the States led by Oldenbarnevelt, and the stadtholder Maurits. There is no proof that his play was ever performed. As far as we can see, the printed publication of the play, only affordable and readable by an elite of its own, expressed pro-war sentiments in such a blatant and one-sided fashion that it is questionable whether the voiced opinion will ever have reached a dissenting audience.

In this view, the topical allusions, adapted to the literary field in which the authors were working, are as much a means as an end. The references to contemporary politics are intrinsic to the genre of national history drama which both authors chose, recognizing its excellent possibilities for interaction with their specific audience. The Orange plays Heinsius and Duym wrote to gain their place within their literary circles gave the subgenre of the national history drama a firm footing in the Dutch Republic. Simultaneously, their written and/ or staged re-enactment of a crucial traumatic episode from recent history contributed to the self-awareness of the young Republic. Here we are in agreement with Greenblatt's notion of the complex interdependence between texts and the cultural and social contexts from which they originate and in which they circulate. Literature both reflects and shapes society. Hence literature can only be partially innovative, critical and unconventional, and partially cannot help but conform to its audience(s).

\section{EPILOGUE: LITERATURE AND THE FORMATION OF PUBLIC OPINION?}

Bloemendal and Van Dixhoorn argue that it should be no less natural for historians to use responses to social, political, religious and other issues which appeared in a literary form as well as other sources. Such literary sources should be used, not primarily as a way of lending historical work an attractive style and artistic treatment but as documents that, in their own right, serve as an integral part of such 
investigations' ${ }^{70}$ If we accept this argument then it would appear that Duym and Heinsius confront us with three potential pitfalls that, especially in combination, may be hard to circumvent: the inseparable way in which opinion is tied up with early modern literature, the process of mimesis implying a virtually untraceable transformation of reality, and the lacunae in time and research which leaves us for now with scattered and fragmented contextual information.

For a start, as we have seen, opinion is not just a recurrent feature in early-modern literature; it is inherent to the whole concept of bonae litterae. There was no literature free from value judgments. Literary form and moral content were inseparably intertwined. In the citizenship education, which was an inherent part of an early modern literary genre such as history drama, political knowledge was a prominent and even integral feature. Therefore, opinion formed literature as much as literature formed opinion. Men of letters not only (pre-eminently) employed literature to convey opinions, but equally made use of opinions to disseminate their literature. In playing with the intended audiences of their plays Heinsius and Duym played with opinion.

Furthermore, the mimetic nature of literature makes it difficult or even impossible to pinpoint the function and nature of a voiced opinion within a literary composition. The editors observe rightly that 'the opinion or opinions contained in it [...] are shaped, refined, and adapted during the creative process'. ${ }^{71}$ Opinions within literature can be a means as well as an end, and even both at the same time. Heinsius, in his dramatic representation of a patriotic message favourable to the authorities, not only conforms to his intended audience, but at the same time entices his public into accepting ancient tragedy in general and his own history play in particular. Then again, although Heinsius on his own account added the final monologue by Prince Maurits only half-heartedly, it turned out to be a major asset in the reception of the play, reinforcing a topical political message.

Consequently, we need to be well-informed as to both the context from which a literary work has originated and its reception history before we can hypothesize about its interaction with the opinions of its respective audiences. What was the social and literary status of the author, in which circles did he operate, and under the influence of

\footnotetext{
${ }^{70}$ Bloemendal and Van Dixhoorn, 'Introduction', p. 4.

${ }^{71}$ Ibidem, p. 34.
} 
which literary conventions? In what form/where/under which circumstances was a literary composition published? What were its intended and actual audiences, as far as we can induce? What kind of responses and/or imitations did it inspire?

In their introductory article, Bloemendal and Van Dixhoorn confine themselves to 'texts which were published, or written with the intention of being published, for a general public, and which aimed at informing, persuading or convincing that public'. ${ }^{72}$ However, this case study demonstrates how a considerable research gap and hasty preconceptions can blur our vision of the intended public. In-depth investigations and balanced visions of such prominent literary circuits as the academic humanist circles and the chambers of rhetoric are a prerequisite for inferences about the audiences at which a literary work aimed and, as far as we can see, actually reached. This article has shown how the playwrights Heinsius and Duym have been held captive in circular arguments that turn out to lack any solid ground. Starting from the premise that Heinsius was an elitist armchair scholar, his play, cast in a language and literary code that is hard to digest for the modern-day scholar, was considered to prove his disengagement and inability to reach an audience of consequence. By contrast, starting from the assumption that Duym must have been a popular playwright, capable of touching the hearts and minds of many people, the Dutch rhetorician was bound to have produced a successful piece of propaganda, voicing popular sentiments, with Duym's own acknowledgement of Heinsius's Auriacus as his source text merely functioning as a cover-up.

Bloemendal's and Van Dixhoorn's criticism of Habermas's polarizing concepts of early modern and modern public opinion, should be separated from the suggestion of using literature as a source for research into the formation of public opinion. Together both theses run the risk of provoking a circular argument of their own. Habermas is rightly criticized with having 'taken a rhetorical strategy used by a specific segment of the population, the eighteenth-century bourgeoisie, to be descriptive of the sociocultural reality that he then goes on to analyze'. ${ }^{73}$ However, if early modern literature is used as the sole foundation for a hypothesized early modern public opinion, the

72 Ibidem, p. 10\#.

73 Ibidem, p. 19\#. 
same danger lies in wait. Literature should not be used as conclusive testimony to support the supposition that a relevant form of public opinion did exist in early modern times. Just as the enterprise of inferring an author's or an intended audience's opinion(s) from a literary product turns out to be a hazardous one, so too the reconstruction of 'public opinion' on the insecure basis of such a complex and opaque phenomenon as early modern literature is equally unfeasible. 
HUGO GROTIUS IN PRAISE OF JACOBUS ARMINIUS: ARMINIAN READERS OF AN EPICEDIUM IN THE DUTCH REPUBLIC AND ENGLAND

Moniek van Oosterhout

When the Leiden Professor of Theology Jacobus Arminius died in August of 1609, Hugo Grotius wrote a Latin poem of 86 scazontes (limping iambics) to commemorate him. Grotius was by no means the only writer to express his opinions about the controversial theologian. His poem was published in two pro-Arminian pamphlets of 1609 with Latin writings by various authors. Over 20 years later, Grotius's poem was translated into English. Grotius's ties to the man who gave his name to the movement of Arminianism in England were remembered in that era. The social and historical context in which the poem appeared in both the Dutch Republic and England are outlined below. This illustrates the points of view about matters of theology that the readers of Grotius's poem held. An analysis of the text of the poem will establish what point of view the poet put across to the readers. It will then be possible to determine how and to what extent this poem was used to advocate the Arminian case in the Dutch Republic and in England.

The Dutch Republic in the year 1609

In April of 1607 an armistice was signed between the Spanish and the Dutch. After more than 35 years, all fighting was suspended. Most of the people then living in the Northern Provinces had never known peace in their lives. Tension ran high between opponents and proponents of peace with Spain: Johan van Oldenbarnevelt, the most important politician of the young Dutch Republic, who was leading the way to a truce, came to stand opposite to the military leader Maurits of Nassau who was a member of the war party. Difficult negotiations surrounding a lasting peace between the two countries eventually led to the compromise of a truce. This Twelve Years' Truce was signed on 
4 April 1609. Grotius was one of the people who predicted the internal trouble that lay ahead for the Dutch Republic now that the binding factor of a common enemy had disappeared. ${ }^{1}$ The Dutch Republic was a loose federation of provinces with their own, differing interests that they sought to address in the first place. It turned out to be difficult to deal with problems that affected the Republic as a whole.

The clashing opinions between the divided Protestants of the Dutch Republic on questions of doctrine came to the fore after the Truce had been signed. These disputes over complicated theological questions became a matter of such importance that they spilled over into the political arena. Over the course of the Truce years, the question of the relation between State and Church became especially troublesome. The power of the States General did not reach into the ecclesiastical organization of the classes. The Counter-Remonstrants were opposed to state power over the Church, while the Remonstrant ministers who were backed by Oldenbarnevelt and his party supported this. Before the religious differences are addressed, their ultimate consequences for society as a whole and Hugo Grotius in particular are outlined here. The problems were catastrophic for the unity and stability of the state. In 1618, at the request of the States General, Maurits of Nassau took control of the government and arrested the leaders of the State party. Oldenbarnevelt was executed for high treason and Grotius was sentenced to life imprisonment. The Remonstrant movement was condemned at the Synod that convened in Dordt in 1618-1619.

\section{THE RELIGIOUS DIFFERENCES}

At the beginning of the Revolt against Spain, from the 1570s, the Dutch Reformation had focussed on the difference between their own religion and the teachings of the Roman Catholic Church of their enemies. When the Reformation became more firmly established, attention was turned to the foundations of Reformed doctrine. Disagreement about these principles soon arose, when the first ministers that had graduated from the Faculty of Theology of Leiden University (established in 1575) started discussing their opinions. Election and reprobation were the main issues upon which they disagreed.

\footnotetext{
${ }^{1}$ See Briefwisseling, 1, 100, dated 21.IV.[1607], to N.N.
} 
In 1603, Jacobus Arminius became the closest colleague of the strict Calvinist theologian Franciscus Gomarus at Leiden University. Arminius was a man of questionable orthodoxy on matters such as election, reprobation and the will of God and man. In his letters to Franciscus Junius and in the works written before 1604, Arminius had put the main structures of his religious thought down in writing. ${ }^{2}$ His opinions on election and reprobation will be summarized here. Strict Calvinism taught that the reason for God's preordination is beyond human understanding, which is a hard point of view that demands considerable resignation and trust on the part of the believer. For Arminius, God was essentially just. He claimed that God in his justice incorporated his knowledge of sinful behaviour in his decision to condemn some people before their lives had started. Humans were attributed with the will to make it possible to reject God's grace by committing sins, but although man is created with free will, he remains totally dependent upon God's grace. Arminius reproached the Calvinists with robbing humans of all responsibility for their actions, since the ultimate result of absolute predestination made God into the author of sin. Since this could not be accorded with God's justice, it was the worst thinkable blasphemy for Arminius. His views on the controversial topics were separated from the frame of his religious thought and he was consequently misunderstood as a squanderer of the Protestant faith. The orthodox Calvinists held that Arminius allowed the behaviour and actions of people room in God's decision about their ultimate destiny.

The language of Arminius's writings was Latin. This assured easy dissemination of his ideas into an international community of readers of the upper circles. Generally, the Latin language provided writers with some freedom of expression, since ideas expressed in that language

${ }^{2}$ Between 1599 and 1602, Arminius wrote Examen modestum libelli, quem D. Gulielmus Perkinsius apprime doctus theologus edidit ante aliquot annos de praedestinationis modo et ordine, itemque de amplitudine gratiae divinae in reaction to a booklet by William Perkins about the same subjects-see Den Boer, Duplex amor $D e i$, p. 6. Arminius's work, however, was not printed until 1612. The theses (titled De natura Dei) presented at his graduation on 19 June 1603 complement the Examen Perkensiani. They were printed in 1603 in Leiden. Judging by Grotius's unpublished poem for Arminius written in 1603, Grotius appears to have perused both Arminius's theses as well as his doctoral oration held at Leiden on 11 July 1603 about the priesthood of Christ. For the poem, see Grotius's Dichtwerken I 2A/B3, pp. 195-200. The existence of the poem in manuscript shows that Grotius had a sympathetic interest in Arminius from the age of 20 . 
were reserved for the priviliged top layer of society which was considered wise enough to handle such information with care. ${ }^{3}$ The lower strata of the population were not supposed to enter the discussion about religious doctrine at any point. Arminius himself claimed that even the Leiden students were unable to judge the points of the controversy, because they did not have enough intellectual baggage to do so. The Remonstrants would always maintain that churchgoers were incapable of understanding the finer points of religious doctrine upon which they disagreed with the Counter-Remonstrants and that these questions should not be spoken about in sermons, since this would only bring about problems. ${ }^{4}$ But tempers flared since there were matters at stake that touched upon the core of religion and the Calvinist clergy was unable to refrain from publicly denouncing Arminius in order to seek support for their own point of view. One of Arminius's fiercest public opponents was the clergyman Petrus Plancius $(\dagger 1622) .{ }^{5}$ As early as the 1590s Plancius had railed against Arminius from his Amsterdam pulpit. ${ }^{6}$ The government of Amsterdam had then interfered in the matter in favour of Arminius. But Plancius would not stop vilifying Arminius and during a sermon held in 1604, Plancius preached against Arminius so violently that he lost his self-control. ${ }^{7}$ Churchgoers and the Amsterdam magistrate were shocked by this unseemly behaviour.

In February of 1604 Arminius had, according to the university schedule, presided over disputations on the subject of predestination. Gomarus had reacted by organizing extra disputations on the same subject in October 1604. ${ }^{8}$ Disputations at the Leiden University were attended by students and professors and despite the fact that they too were a Latin affair, they caused further polarization in society at large. The Calvinists did not want the students of Theology, the future ministers of the church who were in charge of the spiritual welfare

3 See Helander, Neo-Latin Literature in Sweden in the Period 1620-1720, p. 6.

${ }^{4}$ See Van Deursen, Bavianen en Slijkgeuzen, pp. 378-79.

${ }^{5}$ See Keuning, Petrus Plancius. Plancius had no theological publications to his name. Any influence he had on people's opinions in the field was a result of the spoken word.

${ }^{6}$ Ibidem, pp. 21-22.

7 Ibidem, p. 29.

8 Arminius's written reaction to these disputations, entiled Examen Thesium Gomari de Praedestinatione, was, according to Den Boer, Duplex amor Dei, p. 7, published in 1613, but I was only able to locate an edition from 1645 . 
of the people, to be exposed to Arminius's ideas. This was bound to happen through his lectures at the university, but also in the disputations that were held there under his chairmanship. After all, when students became ministers it was their task to treat selected passages of the Scripture at church services, thus taking the people who attended church on a regular basis through large parts of the Bible. ${ }^{9}$ The interpretation of these passages by the ministers influenced the religious stance of their congregation.

Arminius's reputation was tarnished by the reactions to his publications and since 1606, a list of the presumed heresies of Arminius circulated in manuscript. ${ }^{10}$ The role of the correspondence between scholars and clergymen must not be underestimated in this process of tearing down a person's name. Even confidential letters often reached far beyond the addressee. One example related to the present controversy occurred in 1607 when Sibrandus Lubbertus sent letters to international aquaintances about the Conventus praeparatorius, which was a meeting of the clergy for a national synod to be held about the difference of opinion. ${ }^{11}$ At this meeting, Calvinists and those who held a different view were allowed to profess their opinions and as a consequence made matters worse. Lubbertus's report of the meeting informed theologians abroad. Arminius and his friend Johannes Wtenbogaert were kept very busy defending their cause within the Republic and outside. ${ }^{12}$ The initial armistice with Spain had only been signed a month before the meeting (namely in April of 1607), and already the absense of hostilities left room for intense national discussion about issues of religion.

In the first months of the year 1608, the above-mentioned Plancius turned to the Amsterdam government to pronounce his objections to Arminius's point of view yet again. On this occasion, his brother in arms even contradicted some of Plancius's most critical statements. ${ }^{13}$ As a result of Arminius's and Wtenbogaert's complaint to the States of Holland about allegations of unorthodoxy and blasphemy such as Plancius had made, this institution organized a meeting between

\footnotetext{
9 See Van Deursen, Bavianen en Slijkgeuzen, p. 46.

10 See den Boer, Duplex amor Dei, p. 10.

11 See Van der Woude, Sibrandus Lubbertus, p. 161.

12 Around that time, Arminius's reply to the list of his 'heresies' probably circulated in manuscript as well (see Den Boer, Duplex amor Dei, p. 10).

13 Ibidem, pp. 31-32.
} 
Gomarus and Arminius in front of the High Council on 30/31 May 1608. Grotius, then judge-advocate ('advocaat-fiscaal') at the Supreme Court, attended this meeting, where his friend Arminius and his opponent Gomarus spoke. ${ }^{14}$ It was thought that this chance for both parties to vent their opinions in front of a public yet restricted audience would make the controversy more manageable by the government. The speeches that the two theologians made at the meeting were never published. The outcome was not satisfactory, however, and the rowing continued until August of $1609,{ }^{15}$ when Arminius was too sick to comply with the summons that the States had issued to him and Gomarus. He died in Leiden on 19 October 1609 at the age of 49. Despite the death of one of the parties involved in the controversy, it had escalated too far for effective control by the government.

It must be noted that Franciscus Gomarus could at this moment already be called a representative of a group of Dutch Calvinists, whereas Arminius was not backed by a collective that held the same opinions. This is not to say that nobody agreed with Arminius or that he was completely unique in his deviation from the strict Calvinist religious doctrine. But when Grotius wrote his poem, there was no question of an organized religious movement based on Arminius's ideas. It must be concluded that Grotius wrote his poem out of sympathy for Arminius and his ideas.

On 14 January 1610, a remonstrance was addressed to the States of Holland by those who agreed with Arminius. Johannes Wtenbogaert had used Arminius's writings to draw up this document. The remonstrance contained a plea for tolerance for the teachings of Arminius, which were summarized in five points. Among the 43 signatures are

${ }^{14}$ He reported elaborately about the meeting in a letter, Briefwisseling I, 137, pp. 120-22; dated [beginning of June] 1608, N. van Reigersberch.

${ }^{15}$ In October of 1608, Arminius defended himself yet again before the States of Holland. The speech was published against the ban of the States in 1610: Verclaringhe Iacobi Arminii saliger ghedachten: in zijn leven professor theologiae binnen Leyden: aengaende zijn ghevoelen, so van de predestinatie, als van eenige andere poincten der christelicker religie; daerinne men hem verdacht heeft ghemaeckt: eerst mondelingh ghedaen in de volle vergaderinghe vande H.H. Staten van Hollant ende Westvrieslandt, opden 30. octobris 1608. ende daer nae schriftelick aen hare Mo. E. overgelevert (Leiden, Th. Basson, 1610). Gomarus had been kept in the dark about this speech made by Arminius in October and he reacted by making his own speech in front of the States in December of 1608: Francisci Gomari Waerschouwinghe, over de vermaninghe aen $R$. Donteclock (Leiden, Jan Jansz. Orlers, 1609). This oration was also published against the States' ban in the year 1609 (see Rabbie, Ordinum Hollandiae ac Westfrisiae pietas (1613), p. 6). 
famous names such as Simon Episcopius, Caspar Barlaeus and Petrus Bertius. Of these men, Episcopius, one of Arminius' students, became the theologian of the Dutch Remonstrant movement. ${ }^{16}$ Arminius was made into the champion of a movement that derived its name from him, but that did not continue to base their ideas entirely on his writings. The Calvinists were also known as Gomarists after their main representative. With reference to the documents in which they laid down their views, the parties were called the Remonstrants and the Counter-Remonstrants. Attempts first made by the government in 1610 to repress publications about the controversy written by the two parties were not effective. ${ }^{17}$

\section{Grotius's POEM}

Now that the context has been outlined, we will turn to Grotius's funeral poem. First its content will be summarized, then its remarkable form will be discussed. Verses 1 to 18 contain praise for Arminius who is in Heaven. Whether he was wrong or right in his views of the Dutch Reformed religion, Arminius's conscience is clear. Arminius is pictured as looking down on earth, where the Christians are fighting amongst each other (verses 19-45). Theologians and people fight, while truth flees (verses 19-27). Disapproval of the discord among Christians is illustrated by a comparison to the Tower of Babel (verses 38-41). Other religions profit from the disharmony (verses 42-45). Images of the ideal Christian religion and the ideal believer are sketched in verses 46-69. An ideal, uncomplicated religion is described first. Religion should not be about thoroughly understanding doctrine, nor about the question of whether the outcome of things is set at the beginning and in what way God might create or reject evil. God directs all things with his will. In verses 57 to 69 the good Christian is described. The believer should not occupy himself by gathering riches and respect on this earth, but he should strive to get to know God and he should read the Bible. His will is curbed by God's grace. He must be tolerant towards those who hold a different opinion, be modest and know when to speak about what he knows and when to be silent in order

\footnotetext{
${ }^{16}$ As a representative of the Remonstrants in Dordt, Episcopius was exiled. He was one of the founders of the Remonstrant Brotherhood in Antwerp in 1620.

${ }^{17}$ See Weekhout, Boekencensuur in de Noordelijke Nederlanden, p. 43.
} 
to keep peace. All his life, Arminius proclaimed these beliefs (verses 70-77). The poem is closed by Arminius's prayer to God: Christians must breathe as one (verses 78-86).

As concerns the metre of the funeral poem, Grotius wrote it in choliambics or scazontes, an iambic metre in which each verse is closed by a reversed or limping iambe. In Antiquity and early modern times, this metre was mostly used for slanderous poems. ${ }^{18}$ It is difficult to believe that Grotius meant to poke fun at or ridicule the death of Arminius. Later on in his life, Grotius used this metre to celebrate his escape from prison in two poems. ${ }^{19}$ As is the case with the funeral poem for Arminius, the poet does not seem to ridicule the subject of these two poems either: he uses the choliambic metre in poems that do not satirize or slander the subject.

Grammatically speaking, the poem can be divided roughly into ten parts (mostly corresponding to sentences). ${ }^{20}$ As concerns content, four parts can be discerned: an introduction of the main character Arminius (verses 1-18), a sketch of the troublesome situation in which the Christians find themselves (19-45), a description of what the Christian religion should be like (46-69) and in conclusion the sincere efforts of Arminius to make religion better, for which he continues to pray from Heaven. The first and the last of these four parts are about Arminius, while in the two middle parts he is not mentioned at all. This middle part, verses 19 to 69 , consists of 27 verses that are mainly negative in content, followed by 24 verses that are mostly positive in content. The negative part is introduced by verse 18 in which Arminius is described in his blissful position in Heaven, looking down on mankind, who is not doing well at all. The passage is so long that readers will have trouble retaining the person of Arminius in their minds, since the description is not connected to him in any way. The passage culminates in a sketch of the weak position of the whole of the Christian religion as opposed to Islam and Judaism (verses 42-45). Against this spectre the opposite picture of an ideal Christian religion is painted from verse 46 , starting with the signal word 'felix' that is repeated in verse 58 where

\footnotetext{
${ }_{18}$ See J.G. Vossius, Poeticarum Institutionum Libri Tres (Amsterdam, 1647), p. 95, where the use of choliambics is described to be used 'in conviviando'.

${ }_{19}$ See Van Oosterhout, Hugo Grotius' Occasional Poetry (1609-1645), pp. 156-60 and 369-73.

${ }^{20}$ Early modern punctuation is notoriously difficult to understand for us, so a different division is well possible. The proposed division is: 1l. 1-6, 7-17, 18-27, 28-37 (which passage comprises 6 questions), 38-41, 42-45, 46-56, 57-69, 70-77, 78-86.
} 
the description of the ideal Christian believer starts. It is only in verse 70 that this positive image is connected to Arminius, who is after all the principle character of the poem. The connection is made by the words 'haec monebas' in verses 70 and 72). 'Haec' roughly refers to the above, but it is not clear whether the passage about the disharmonious Christians should be included.

Many adjectives are used in the poem to reinforce the morally good and bad images in the poem. A few examples suffice to demonstrate this. The age is dark indeed: see verse 4 'saeculo tenebroso' and again in verse 75 which as a whole belongs to 'saeculi' in verse 74: 'fastidiosi, pertinacis, ingrati'. Of course in the poem Arminius is surrounded by positive adjectives: he is 'sublime pectus' (verse 2) and he inhabits 'the splendid fields of blessed light' (verse 6). In the poem, Arminius is pictured as a sympathetic man who strove for a sympathetic ideal in an indefatigable manner. Removal of the tens of adjectives from the poem leaves the reader with a much weaker and less persuasive piece of writing.

The attraction of the poem for the reader of the year 1609 lies in the reduction of the importance of the complicated dogmatical issues in favour of a minimum of practical precepts. In verses 46-69, a small list of points is supplied which should not be questioned by believers. Grotius, who never received a formal theological education, would continue down the same road: he was averse to religious dogmatics and in favour of a small number of practical indications on how to live one's life. The actions of man stood above doctrinal finery. In order to be a good Christian it was unnecessary to have a precise understanding of the subjects of the controversy between Arminius and Gomarus. But these men were professionally occupied with questions of doctrine. Theologians should, according to Grotius, know the proper time and place to speak about these issues (see v. 69). In other words, they should be careful about spreading information and opinions that may cause problems among churchgoers. This elitist point of view shows that Grotius ascribed great influence to spoken and written words on the part of listeners and readers. ${ }^{21}$

Grotius's epicedium in honour of Arminius was the poet's first public statement on Christian theology. ${ }^{22} \mathrm{He}$ was to repeat this vision of

\footnotetext{
21 See Van Deursen, Bavianen en Slijkgeuzen, p. 278.

22 See Ter Meulen-Diermanse, Bibliographie Grotius, nos. 919-1209.
} 
peace among Christians later on in his life. In his view peace was necessary to arrive at the truth; bickering about doctrine only diverted Christians from more important matters, such as reading the Bible. Grotius clearly shows his sympathy for Arminius in the poem and he was automatically classified with the Remonstrants. In the years that followed, he became Oldenbarnevelt's right-hand man and a leading figure of the State party that protected the Arminians by enforcing toleration of their views. Grotius was clearly confident about this politico-religious course, since in 1616, when tension between the State party and the Counter-Remonstrants was mounting daily, he still saw fit to include the epicedium on the death of Arminius in his collected poetry, the Poemata Collecta (Leiden, 1617). Verses 7 to 9, however, are mitigated in this edition. It is highly probable that these verses refer to the renounced Roman Catholic religion that is here classified as an oppressing slavery of a godless cult, but the verses may also be understood as being about Arminius's opponents. The mitigation of the passage points to the second possibility, because by that time Grotius had become more careful about antagonizing people unnecessarily. Grotius had grown wiser over the years, especially since his tract on the supremacy of the government in church affairs, the Ordinum Pietas of 1613, had received a negative response. ${ }^{23}$ One of the people Grotius had involved in the publication was Petrus Bertius, whom we shall meet in the next paragraph. The after-effects of this publication were very severe. From that point on, Grotius became meticulous about what he published and with whom he collaborated.

\section{A pamphlet by Petrus Bertius}

Grotius's poem is meant to incite or strengthen sympathy for Arminius, and this intention is reinforced by the publication in which it was included. At the funeral on 22 October 1609 in Leiden, Arminius's friend Petrus Bertius held the funerary oration. He had been instructed by the States not to speak of the troubles in which the dead man had been involved. The oration was published along with several epicedia in Petri Bertii Oratio In obitum Reverendi et Clarissimi viri D. Iacobi Arminii. Grotius's poem was the first to follow Bertius's description

\footnotetext{
${ }^{23}$ For this publication, his collaborators and the aftermath, see Nellen, Hugo Grotius, pp. 148-63.
} 
of Arminius's life and death. The most notable poet among the other authors in the pamphlet is Simon Episcopius, whose poem called Thre$n u s$, which is a song of mourning, runs to over seven pages. ${ }^{24}$ While nowhere did the authors of the pamphlet openly name Arminius's opponents, they nonetheless managed to cast these people in a poor light, because they resorted to praise of and emphasis on the superiority and good intentions of Arminius. The accumulation of texts that are unanimous in their views causes the message to be drummed into the minds of the readers by repetition.

The text of Grotius's poem in the pamphlet contained five printing errors (see app. crit. to the poem). In a letter to Grotius of 21 December 1609, Bertius blamed the copier or typesetter for these mistakes. ${ }^{25}$ The most annoying error occurs ten lines before the end of the poem, where Bertius's text reads 'solus' ('alone') instead of 'totus' ('totally'): '[...] regna solus arderes.' ('[...] you alone desired ardently the realm.') The meaning of the verse has changed in Bertius's version, making Arminius the only one who truly longed for Heaven. Bertius wrote to Grotius that he was himself accused of attributing the evil intention to the poet Grotius of wishing to have all others damned and ascribing the kingdom of the heavens to Arminius alone, thus leaving other theologians (read: those who did not agree with him) out. Bertius apologized profusely for this 'mistake'. Grotius's reply to Bertius's letter is no longer extant, but he must have been annoyed by Bertius's careless editing of the text of his poem.

The poem came to the attention of Franciscus Gomarus. His grievance is passed on to Grotius by way of a letter written by a friend on the same day as Bertius wrote to Grotius (21 December 1609). ${ }^{26}$ It was not just the misprint that caused Gomarus's irritation; he clearly felt that Arminius's opponents (including Gomarus himself) had been made into the aggressors, because Arminius is depicted as the model of innocence and good intentions. Grotius wrote a letter to Gomarus explaining his motives for writing the funeral poem. ${ }^{27} \mathrm{He}$ wrote that he had always admired Arminius's striving for peace in the church. Grotius continued the letter by claiming that he had no exact knowledge

\footnotetext{
${ }^{24}$ The other poets are Justus van Swanenburg, Jacobus Lettingius and two poems called Ad eundem Scazontes and Epigramma in morbus eiusdem by V.R.

${ }^{25}$ See Briefwisseling, 1, 180, p. 157; dated 21.XII.1609.

${ }^{26}$ See Briefwisseling, 1, 179, pp. 156-57; from Janus Rutgersius.

27 See Briefwisseling, 1, 181, p. 158; dated [24.XII.] 1609.
} 
of the theological disputes. It is difficult to believe that Grotius is telling the truth here, for he was a man of the sharpest intelligence. It is rather more plausible that he is expressing his opinion on how questions of religious doctrine that cause tumult among theologians must be dealt with. Grotius always maintained that the basic principles of religion must be comprehensible to all believers.

In the letter to Gomarus, Grotius further mentions that the teachings of Arminius's predecessor Junius made a profound impression on him. Junius had been an advocate for tolerance of diverse opinions in the church as well as Arminius. Grotius sums it up to Gomarus as the only solution: 'Restat ut feramus alter alterum' ('It remains for us to tolerate each other'). In fact this means that it is up to Arminius's opponents to put an end to the troubles by tolerating Arminius's ideas. As we have seen, the enforcement of the tolerance of Arminians within the church by Oldenbarnevelt and his right hand man Grotius would fail in the long run.

Altogether Bertius's pamphlet contained 60 pages in defence of Arminius which Gomarus simply could not leave uncontradicted. Besides his comments upon Grotius's contribution to the pamphlet, Gomarus's objections to Bertius's oration were printed..$^{28}$ Bertius did not leave this pamphlet unanswered either. ${ }^{29}$

\section{A pamphlet by Dominicus Baudius}

The version of Grotius's poem presented in the appendix to this chapter is the authorized text that is found in a pamphlet edited by the Leiden Professor of Rhetoric Dominicus Baudius: Epicedium dictum honori Jacobi Arminii. It contains the correct edition of Grotius's epicedium (funeral elegy) and it was published before the end of 1609. ${ }^{30}$ The pamphlet further consists of Baudius's own lengthy poem on the death of Arminius. Baudius's epicedium contains elements similar to Grotius's poem; there is a warning not to ask too many questions

\footnotetext{
${ }^{28}$ Franciscus Gomarus, Proeve van M.P. Bertii Aenspraeck (Leiden: Jan Jansz Orlers, 1610).

${ }_{29}$ Petrus Bertius, Aen-spraeck, aen D. Fr. Gomarum op zijne bedenckinghe over de lijck-oratie ghedaen na de begraefenisse van D. Iacobus Arminius (Leiden: Jan Paets, 1610).

${ }^{30}$ Dominicus Baudius, Epicedium dictum honori Jacobi Arminii (Leiden: Andreas Cloucquius, 1609).
} 
about doctrine, or peace will be disturbed and schism will be the ultimate consequence. The pamphlet is dedicated to the States General. The dedication to this important governing body may be an attempt to draw public attention and lend weight to his publication and the opinions expressed in it. In the letter of dedication, Baudius wrote that Arminius had failed to listen to his advice and that now only the authority of the State could put a stop to the religious troubles.

The fact that Baudius's involvement in the troubles was a matter of debate among scholars is something that becomes clear in a letter written by the humanist Ubbo Emmius, who encourages a friend to read Baudius's pamphlet: 'Legistine Epicedion eius in mortem Arminii, cum praefatione dedicatoria ad Illustres Ordines? Lege, lege et ride aut ingemisce. ${ }^{31}$ ('Did you read his epicedium on the death of Arminius, with a preface that is dedicated to the Illustre States? You should read it and laugh or sigh.'). According to Emmius, Baudius's efforts cause derision or annoyance. In a letter to Johannes Wtenbogaert, Baudius himself claims that his poem is misinterpreted as a poem that is critical of Arminius. ${ }^{32}$ In their two poems Grotius and Baudius voiced the same concern about undue curiosity to penetrate the dogmas, and in both poems the disagreement in the church is condemned. Grotius's poem, and therefore his opinion on the subject, was taken more seriously than that of Baudius. These contrasting reactions to the same ideas have to do with the general image of the two writers: Grotius was creating a serious reputation for himself as a scholar and a politician, while Baudius was known to be a bon vivant given to debauchery. ${ }^{33}$ This shows that publications containing comparable points of view could nonetheless be received very differently due to established opinions about the authors.

Contrary to Bertius's pamphlet, Grotius's name is announced on the title page of Baudius's pamphlet: Accedunt Grotii V.C. Epicedia in eundem ('In addition there are funeral elegies on the same [Arminius] by the most famous Grotius'). Baudius wrote a short preface that precedes Grotius's epicedium in which he is critical about Bertius's role as the editor of Grotius's poem. Baudius states that Grotius had supplied

\footnotetext{
${ }^{31}$ See Brugmans, Briefwechsel des Ubbo Emmius, 2, 341 p. 96, dated 7.II.1610, to J. Witten.

${ }^{32}$ See Grootens, Dominicus Baudius, pp. 195-96.

${ }^{33}$ Ibidem, p. 227. Baudius was an alcoholic; he died in August of 1613 when he was unable to recover from another drinking bout (ibidem, pp. 223-24).
} 
him with the authorized text of the poem for his pamphlet. Baudius further writes:

because without the permission of the people the funeral orator [i.e. Bertius], while claiming sovereignty over the Copy for himself, changed certain things in a fraudulent and incompetent manner, by very audacious conduct, and by not imitating capable people. Other mistakes can be ascribed to the carelessness of the typesetters, but this must not be excused by way of any indirect manner of speaking, that the word "solus" is substituted by "totus" in the tenth last verse of the scazon: a thought that brings about great damage and has a lot of striking depreciation of many pious men. Rightly and as it should be plain minds must act, if they do not know how to measure with their own standard and rhythm and they should not appropriate license to change anything in these works, the virtues of which they have barely learned to understand with their intellect and admiration. ${ }^{34}$

The purport of the preface is that if an editor (read: Bertius) does not understand a poem, he should not make changes to it. Baudius does not consider all of Bertius's typesetting errors to be mistakes. The instance where 'totus' is replaced by 'solus' is regarded as inadmissible.

After Baudius's pamphlet had come off the printing press, such cutting accusations at the address of Bertius were considered undesirable and a piece of paper that contained the enlarged title of Grotius's poem was printed to cover the preface. It is not known on whose order this happened: perhaps Baudius regretted his own rash actions or Grotius wanted Baudius's critical preface to be omitted. In some copies of the pamphlet this piece of paper is glued across the preface, but sometimes it is bound into the booklet separately, so that all is in the open for the reader to peruse. This indicates the interest that was taken in the matter.

${ }^{34}$ From Briefwisseling, 1, p. 156, n. 4. The full text runs: 'Benevolo Lectori. Quod hanc eximiam purpuram curavi intexendam panno meo, feci auctore non nolente, invitatus elegantia scripti, et gravitate sententiarum, in quibus elucet iudicii generosa libertas, et animus omni affectu maior aut intactus. Heic ipsum rarae mentis et laudis monumentum exhibemus ut est a patre natum: quia laudator funebris sine populi suffragio usurpans sibi Dictatorum maiestatem quaedam fraudulenter et absurde interpolavit, audaci sane exemplo, nec probis hominibus aemulando. Caetera possunt condonari typographorum incuriae, sed illud nullo schemate excusari debet, quod vox solus substituta sit pro totus in versu scazontis qui decimus est a fine: magna cum sensus iactura, nec non cum insigni multorum piorum deprecatione. Recte et ordine facerent vulgares animae, si suo pede ac modulo metiri nossent, nec sibi licentiam arrogarent aliquid immutandi in iis operibus, quorum virtutes vix intellectu et admiratione consequi didicerunt.' 
The number of copies of these pamphlets is unknown, but we can assume that a maximum of 1000 copies per edition were made. ${ }^{35}$ Moreover, pamphlets were passed along to other readers by the initial buyer which means the reading audience will have consisted of several thousands of people. The language of the pamphlet and of Grotius's poem is Latin, which immediately limits the public that was able to read it to the top layer of society in the Republic and to readers of Latin outside the country, for Latin pamphlets were export products. Printing houses sold or exchanged Latin publications with foreign bookshops, visitors to the Republic bought pamphlets and took them abroad and Dutch buyers sent pamphlets abroad to friends. ${ }^{36}$ The readers of these pamphlets were scholars, men of government and ministers of the church who had also visited the Latin school. They will have been mostly male (women were not encouraged to learn Latin), and they will have been influential people. From the time of Arminius's appointment in Leiden, the number of pamphlets with politico-religious content grew, both in Latin and in the vernacular. Both pamphlets escaped the 1610 prohibition by the States of Holland on publications about the position of the government in ecclesiastical matters. ${ }^{37}$

Grotius's epicedium appeared in the first year of the Truce between the Dutch Republic and Spain, at a time when the problems between the Leiden theologians quickly became a matter of public debate. Grotius was then an authoritative poet and a rising political star, whose opinions were considered well worth knowing. The text encourages the reader to sympathize with the theological ideas expressed in the poem.

${ }^{35}$ It is estimated that about 1,000 copies per publication were printed in the 16th century (see Maczkiewitz, Der niederländische Aufstand gegen Spanien, p. 179). One of the reasons underlying this estimation is that the lead type was worn badly after one thousand sheets of paper had been printed. The only information on print numbers of Grotius's publications is that 500 copies of his pamphlet De Antichristo were initially printed in 1640 (see Nellen, Hugo Grotius, p. 497). The printer had underestimated the interest in this controversial tract and a reprint was made quickly.

${ }^{36}$ Both pamphlets that have been discussed can today be found in many Western European university libraries. Bertius had his Oratio in obitum Jacobi Arminii printed by Jan Jacobszoon Paets, the university printer of Leiden, who operated the printing house from 1603 to 1619. Baudius had his Epicedium dictum honori Jacobi Arminii printed with Andries Clouck in Leiden, who operated his firm from 1602 to 1630. Bertius's pamphlet is in Amsterdam, The Hague, Utrecht, Leiden and Deventer, and abroad in libraries in Germany, England and Scotland, France and Italy. Baudius's pamphlet is in Amsterdam, The Hague and Leiden, and abroad in Germany, England, France and Denmark.

37 See Weekhout, Boekencensuur in de Noordelijke Nederlanden, p. 43. 
The poem rejects the fighting between theologians without explicitly mentioning Arminius's opponents. These facts made the poem interesting reading material for upper-class readers of Latin, who could easily obtain the poem, since it was included in two cheap pamphlets. Since the content of these pamphlets was pro-Arminian, readers ranged Grotius on the side of the adherents of Arminius. Grotius must have realised the effect the poem would have on his reputation and he consciously connected his name to Arminius and his views.

When the first edition of Grotius's poem was published by Petrus Bertius in a pamphlet that also contained his funeral oration for Arminius, its influence on the opinion of readers about the theological debate was a source of discomfort for Arminius's most vociferous opponent, Franciscus Gomarus. He feared the persuasive power of the text to agree with Arminius and to turn against his opponents. Since the poem as a whole does not point to specific persons or groups as the guilty party, Gomarus had to pour his objections into a single word near the end of the text which he interpreted as an attack. This word was declared an error by Grotius and the corrected text was quickly printed again by Dominicus Baudius. But while Baudius publicly strove to save Grotius's reputation among readers in a preface to Grotius's poem, his cutting words at the address of Bertius were considered undesirable by unknown others who were involved in the publication of Baudius's pamphlet. Somebody definitely did not want readers to connect Grotius's name with the negative sides of public debate surrounding the theological problems. The piece of paper that was supposed to be glued over Baudius's preface is not found in that place in all of the remaining pamphlets. Readers obviously wanted to learn the ins and outs of the meaning and intention of Grotius's poem in order to establish whose side the poet was on.

The matter of the poem was handled in private letters between Gomarus and Grotius. But Gomarus had his reactions to Bertius's funeral oration printed, this pamphlet challenging Bertius to another response in print. Over the course of the Truce years, the States of Holland attempted to prohibit such publications on the subject of theology that fed the ongoing difference of opinion between the Remonstrants and the Counter-Remonstrants. These publications obviously caused feelings to run much more highly than Grotius's poem, which did not fall within the scope of this censorship. The text itself does not encourage hostile feelings between the two parties. The poem was 
reprinted among the hundreds of poems of Grotius's 1617 Poemata Collecta. Several reasons can be put forward for reprinting the epicedium despite the fact that it had publicly endangered Grotius's reputation six years before. In the Poemata Collecta the poem was taken from the pro-Arminian context of Bertius's and Baudius's pamphlets and it could thus be more easily appreciated for its literary value. It was, after all, a well written poem, of which the Latin had even been praised by Gomarus. When the collection of poetry was edited, the ecclesiastical politics of Oldenbarnevelt and his right-hand man Grotius were heavily criticized by the Counter-Remonstrants. Grotius must still have been convinced of the correctness of the political course concerning the trouble between the Remonstrants and the Counter-Remonstrants. He must have felt that his funeral poem for Arminius would not cause further problems, whilst serving to enhance his own reputation as a poet. The Poemata Collecta was read by fewer people and in this context the poem will not have been played a role in public debate about the religious problems.

\section{Grotius AND ENGLAND}

Grotius's funeral poem for Arminius was translated into English by a poet called William Cartwright (1611-1643), who was a dramatist and a preacher. This translation was first printed in 1651, but it was probably a product of the 1630s, when King Charles I and his closest advisor William Laud, the Archbishop of Canterbury, pursued a moderate Arminian course in English church politics. Since the English church model appealed to Grotius, he was an ardent admirer of Laud, whom he praised for his respect for the traditions of the early Christian Church, his repudiation of Roman abuses and his rejection of the Calvinist views on predestination. In the early 1630s Grotius attempted to set foot ashore in England, but although Laud said much in his praise, Grotius was unwelcome in this country. ${ }^{38}$ In 1635 Grotius became ambassador to Sweden in Paris. He did not fare well in French politics and focussed his attention on other projects. He devoted progressively more time and effort to his irenicist ideals of a united Protestant Church. England was central to Grotius's programme of

\footnotetext{
${ }^{38}$ See Trevor Roper, From Counter-Reformation to Glorious Revolution, pp. 63-65.
} 
religious reunion and he hoped to become the Swedish ambassador in that country. Grotius was optimistic about the negotiations to achieve a political alliance between England and France, in which Sweden and the Dutch Republic would also be able to participate. Were a pact to be signed, the unification of the Protestant Church would surely lie ahead. Grotius was also hopeful about the efforts of the Scottish clergyman and intellectual John Dury to prepare the way for a unification of the Swedish, German and English Churches. ${ }^{39}$ But Grotius's contact with Dury turned sour, ${ }^{40}$ and France and the Dutch Republic would never sign a treaty with England, since Laud's church politics were too fanatical to their tastes. Grotius was further disappointed when he received the news of the reservations that the Archbishop harboured concerning his offer of the programme of Christian reunion to the English rulers. Laud avoided direct correspondence with Grotius. An English destination became undesirable for Grotius himself when in the following year Arminianism fell in that country and Laud was locked up in the Tower of London.

Although Archbishop Laud discouraged Grotius from coming to England, there was sufficient interest in the poet Grotius for three printed publications of poetry from his early years to appear in England between 1637 and 1640. Over 20 pages of his epigrams were published in an anthology of Latin epigrams collected by the English priest Abraham Wright (Delitiae delitiarum or Ultimate Entertainment, Oxford, 1637). ${ }^{41}$ This collection was dedicated to William Haywood, Laud's chaplain and, from 1637 onwards, chaplain to King Charles I. In Wright's dedication, there is a reference to Grotius's funeral poem for Arminius, a poem which is not included in the anthology of Latin epigrams. The reference reads: 'Here you can read the investigator of lofty poetry, Grotius' ('Hic altae poeseos scrutatorem legas Grotium'). ${ }^{42}$ Grotius is called 'altae poeseos scrutatorem' or 'the investigator of lofty poetry', which refers to the opening line of the epicedium on Arminius who is there called 'the investigator of lofty truth' ('altae veritatis scru-

39 See Nellen, Hugo Grotius, p. 453.

${ }^{40}$ See Trevor Roper, From Counter-Reformation to Glorious Revolution, p. 69.

${ }^{41}$ Abraham Wright (1611-1690) studied in Oxford, where he was well received for his eloquence. He was chosen to address Charles I in a welcoming speech in 1636 when Laud received the king. He was ordained into the priesthood, but was forced to relinquish his position. See Evans, William Cartwright: Plays and poems, and Goffin, The Life and Poems of William Cartwright.

${ }^{42}$ See Delitiae, p. $\nmid 3 \mathrm{ij}^{\mathrm{r}}$. 
tator'). By making this reference, Wright presumes that sympathizers of Arminianism in English ecclesiastical circles (including Haywood), who were the intended readers of his publication, knew Grotius's epicedium for Arminius.

In 1638, Grotius's Poemata Collecta of 1617 were reprinted in London. Like Wright's collection of epigrams, this was an unauthorized edition (containing many misprints and pagination errors) with the addition of the biblical dramas Christus Patiens (written in 1608) and Sophompaneas (1635). There must have been considerable interest in Grotius's poetry in England at that time, or the printers would not have ventured to reprint the volume of 1617. Grotius heard of this volume in July 1639, but he was no longer interested in his Juvenilia Carmina. ${ }^{43}$ The English editor was William Bray ( $\left.\dagger 1644\right)$, another one of Laud's chaplains and a canon at Canterbury from $1638 .{ }^{44}$ In this edition, Grotius's funeral poem for Arminius was released again into high English church circles. The third printed publication of Grotius's poetry appeared in 1640. It was an English translation of one of the plays that had been added to the London edition of the Poemata Collecta, the Christus Patiens. ${ }^{45}$ The translated play was printed in 1639, titled Christ's passion. A tragedy; with annotations (London, 1640). ${ }^{46}$ The translator, George Sandys $(\dagger 1644)$, dedicated the play to King Charles I ${ }^{47}$ and an English poem of praise for Grotius and Sandys was added to the translation. The elogium was written by Lucius Cary, the second Viscount of Falkland $(\dagger 1643)$, a politician and army man who supported the Arminians. ${ }^{48}$

\footnotetext{
${ }^{43}$ See Briefwisseling, 10, 4219 p. 478, dated 23.VII.1639, to Willem de Groot.

${ }^{44}$ See Eyffinger, Inventory of the Poetry of Hugo Grotius, p. XXXIX. Bray was one of Laud's censors who was responsible for licensing books (see McCullough, 'Making Dead Man Speak', p. 407).

${ }_{45}$ The English translation of Christus Patiens was the only edition of his work that came out in England in the years 1637 to 1639 that was to Grotius's liking, for he thought it was well translated and the notes met with his approval as well (see Briefwisseling, 10, 4405 p. 771, dated 26.XI.1639, to W. de Groot). This judgement was shared by the readers, for the translation was printed several times (see Ter MeulenDiermanse, Bibliographie Grotius, nos. 43-48).

${ }_{46}$ Full text of the play in the 1687 edition: <http://eebo.chadwyck.com>.

47 Sandys dedicated all his works to King Charles I, such as narratives of his travels and other translations.

${ }^{48}$ As a member of the Parliament, he opposed the Grand Remonstrance of 1641, a document that reflected the mistrust of the English Parliament towards Charles I and accused Laud of misleading the King.
} 
William Cartwright translated Grotius's poem into English for Arminius. ${ }^{49}$ This translation must be seen in the light of the interest in the figurehead of Arminianism and as such the poetry had iconic value. Whereas the original version of the poem could only be read by those who knew Latin, translation made the poem available to a much larger audience who could read the poem for themselves and to others. The playwright and clergyman Cartwright was an ardent royalist, a wholehearted Laudian and a great admirer of Arminius, which is apparent from his writings. ${ }^{50}$ Cartwright's poems enjoyed wide manuscript circulation, for the editor of the 1651 edition had trouble collecting them all. ${ }^{51}$ The number of readers of the manuscript version of the translated poem can only be estimated. The translation was first printed in the 1651 edition Comedies, tragi-comedies, with other poems, by Mr William Cartwright (London). The unknown editor claims that his edition contains only juvenilia, and that scarcely any of these poems were written after Cartwright turned 25, so after $1636 .{ }^{52}$ In view of this assertion, the translation of Grotius's poem probably dates from the early $1630 \mathrm{~s}^{53}$

English readers of both the Latin and the English versions of Grotius's poem were able to identify with the difficult situation in which Arminius found himself as a result of his point of view in matters of theology. Of course, readers also knew what eventually happened to Grotius: he was exiled for serving the pro-Arminian party that was defeated. The combination of the poem and the fate of the poet were a powerful instrument in strengthening the opinion of readers in favour of the Arminian ecclesiastical politics of Laud. The poet must have been frustrated about the admiration for his Arminian past, while he harboured such great plans for a Christian reunion.

Unfortunately, there is no information about the reception of Grotius's poetry in England in that period. It therefore cannot be ascertained how many people read the translation of Grotius's epicedium

${ }^{49}$ See Evans, William Cartwright: Plays and poems, pp. 497-99 and Goffin, The Life and Poems of William Cartwright, pp. 70-72.

${ }^{50}$ See Tyacke, Aspects of English Protestantism, p. 235. See also Goffin, The Life and Poems of William Cartwright, p. xix. According Goffin, Cartwright's death was mourned by the King personally (p. xxvii).

${ }^{51}$ Ibidem, p. [5].

${ }^{52}$ Ibidem, p. [10].

53 See also Evans, The Life and Poems of William Cartwright, p. 729. 
for Arminius and how these readers responded to the poem. It is plausible, however, that they were adherents of Laud's Arminian church politics, readers who were interested in a poet who they knew had given his best for the Dutch Arminians both in the Dutch Republic before 1618 and from Paris after 1621.

\section{IN CONCLUSION}

In early modern times, poetry was regarded as a pleasant textual genre that made readers susceptible to the news and/or the message put across by the poet. If a poet was authoritative like Grotius, reading his work produced an effect on readers. Examples of character and behaviour such as displayed by Aminius (according to Grotius's poem) were considered sound moral education for readers. Of the great many occasional poems written in Neo-Latin, Grotius's epicedium has been handed down to us because it was considered to be a good poem written by a famous author about a famous person. Readers were also interested in Grotius's public announcement of his sympathy for Arminius and his theological point of view, because the problems concerning the Dutch Protestant Church affected their daily lives. Grotius's poem helped them defend or strengthen their own opinions. Poems by lesser authors were less suitable to quote in conversation or debate. The influence of Grotius's epicedium on readers was therefore feared by Arminius's opponents.

By means of this poem Grotius connected his fate to that of the Arminian movement that was beginning to take shape. The poem marks the first step of Grotius's development as an Arminian champion. But during his years of exile, Grotius drifted away from Arminianism to sail his own irenicist course. He also became very critical of the occasional poetry of his younger years.

The role the epicedium played in the public debate about English Arminianism more than twenty years later was different. In England, it was reprinted in Latin and its translation circulated in manuscript. The poem might have influenced the opinion of upperclass readers of Latin and readers of English who could get their hands on the manuscript version. English readers were able to compare the Dutch ecclesiastical situation in which Arminius and Grotius lived to their own problems between the English Arminians and Calvinists. Of course, their knowledge about the developement of Dutch Arminianism and Grotius's fate 
interacted with their reading of the poem. It is plausible that adherents to the Arminian cause identified with the struggles of the man who gave his name to their movement as described by a poet who was to suffer severely at the hands of his countrymen who did not share his opinion about ecclesiastical politics. To English Arminians the poem has the iconic value of a literary exemplum of the near past. 


\section{APPENDICES}

Editions of Grotius's funeral poem for Arminius

Dominicus Baudius, Epicedium dictum honori Jacobi Arminii (Leiden: Andreas Cloucquius, 1609), p. D3 ${ }^{\mathrm{r}}-\mathrm{D} 4$; ; Petrus Bertius, Oratio in obitum Jacobi Arminii (Leiden: Ioannes Patius, 1609), pp. 46-48; Hugo Grotius, Poemata Collecta (Leiden: Andreas Cloucquius, 1617), no. 75, pp. 304-06; Hugo Grotius, Poemata (Leiden: Hieronymus de Vogel, 1639), pp. 262-65; Hugo Grotius, Poemata collecta (London: Richard Hodgkinson, 1639), pp. 304, 305, 310, 311 (wrong paging); Dominicus Baudius, Poemata (Amsterdam: Ioannes Ianssonius, 1640), p. 150; Hugo Grotius, Poemata omnia (Leiden: Hieronymus de Vogel, 1645), pp. 221-23; Hugo Grotius, Poemata omnia (Amsterdam: Johannes van Ravesteyn, 1670), pp. 210-12; C. Brandt, Historia vitae Jacobi Arminii (Amsterdam: Martin van Schagen, 1724), pp. 484-87; C. Brandt, Historia vitae Jacobi Arminii, editio multo correctior (Braunsweig: Frid. Guil. Meyerus, 1725), pp. 223-24.

Translations of Grotius's funeral poem for Arminius C. Brandt (ed.), J. Guthrie (trans.), The Life of James Arminius (London, etc.: s.n., 1854), pp. 322-25; W. Mallinckrodt, 'Grotius' gedicht op het sterven van Arminius', Geloof en vrijheid: Tweemaandelijksch tijdschrift, 40, N.S., 17 (1906), text from PC 1639, pp. 70-73, trans. pp. 30-35. Ll. 28-35 and 78-86 quoted by Ellinger, Geschichte der neulateinischen Literatur Deutschlands im sechzehnten Jahrhundert, pp. 214-15. 
In mortem reverendi eruditissimique viri domini Iacobi Arminii, in Academia Lugdunensi Divinae sapientiae Professoris, Hugonis Grotii scazon

Scrutator altae veritatis Armini, sublime pectus, anima feta doctrinae, sollertiaeque perspicacis exemplum, tu nunc ademptus saeculo tenebroso et semicaecae palpitantium turbae claros beatae lucis incolis campos. Et, sive nuper magna pars stetit veri tuis sub armis, tot premente cervices cultus profani servitute discussa, seu parte in aliqua, more gentis humanae et nescientis multa sorte naturae, te cepit error (iudicent, quibus sacri iuris potestas, visque tanta noscendi), certe superni codicis frequens lector, in verba certe non adactus humana, labi timentis, nec rebellis in sese, fers teste caelo conscientiae laudem. Ibi satur quiete, gaudii plenus, quaesita quondam discis, et vides, quanta involvat homines inscientiae nubes, quam nil sit illud, quod vocamus hic scire, quo nos superbi tollimus caput caelo; calcamus alios, invicemque calcamur. Hinc tanta bella saeviunt magistrorum, hinc odia plebis: interim fugit longe, nec se videndam dimicantibus praebet amica sanctae sancta Veritas Pacis. Unde ista rabies, et libido pugnandi insedit animos? Cur placet Deus belli materia? Quo tot studia, tot novae partes?

Tit.] The title is glued into some copies of the edition or bound in separately to cover a 'praefatio' by Baudius, underneath which the title is 'In Iacobi Arminii mortem Hugonis Grotii scazon': In Mortem Jacobi Arminii P.C. 1 altae] almae Bertius 7 Et, sive nuper magna pars stetit veri] Et, sive multum debuit tibi verum P.C. 8-9] del. P.C. all editions 19 quaesita] quaesitae P.C. 1639 London (v. 17) 


\section{Translation}

A choliambic poem by Hugo Grotius on the death of the venerable, most erudite Jacob Arminius, Professor of Divinity at the Leiden Academy

Arminius, researcher of the profound truth, distinguished of heart, soul full of doctrine, exemplar of discerning understanding, you, who have been removed from this dark age and from the half-blind crowds of people who tremble, you inhabit the splendid fields of magnificent light. And, if a large part of the truth recently stood under your eloquent defence, when the slavery of an irreligious devotion, which presses on the necks of so many, was cast off, or an error has seized you in a certain respect, in the way of the human race and nature which is by its destiny ignorant of many things (may they pass judgement, who have the power of holy justice and such great force of perception), you, definitely a frequent reader of the celestial book, who are certainly not bound by an oath in human words, you carry the excellence of your conscience, which is afraid to lapse, and not rebellious toward itself, as heaven is your witness. (18) There, rich in tranquility, full of joy, you learn what was once sought and you see what a great cloud of ignorance surrounds people, how insignificant is that which we call knowing here, on account of which we haughty people lift up our heads to heaven; we trample on others and in turn are trampled on. Here, so many conflicts of masters rage, here, the hateful behaviour of the people rages: in the meantime holy Truth, friend of holy Peace, flees far away, and appears to be invisible to those who fight. (28) From where has this madness and craving for fighting taken hold of our hearts? Why is God popular as a cause for war? What purpose does so much partiality, do so many new parties serve? 
An hostis atra nocte pestilens Christi insparsit agro semen? An furor pugnax mortalitatis ingenique corrupti alimenta quaevis sumit et Dei causae permiscet hominem? Curiosus an mundus dum nil latere patitur et sequi gaudet sciri negata, iure sentit hanc poenam? Ut illa quondam, dum viam parat coelo, structrix superbae molis, insolens turba in mille linguas abiit atque aberranti sermone priscum vocis exuit foedus. Heu quid paramus? Lectus orbe de toto grex ille parvus lancinamur heu foede iterumque et iterum, scindimurque discordes, ridente Mauro, nec dolente Iudaeo.

Felix remota factionibus vulgi religio simplex, arte non laborata, quae morte Christi certa dilui culpas, hic spem fidemque ponit, et dari credit gratis salutem promerentibus poenam; sanctique amoris lene munus exercens non curat altum sapere, nec nimis quaerit, an lege certa veniat omne venturum, exsors malorum quomodo malum nolit velitque Rector, summa quatenus causa potente nutu velle temperet nostrum. Felix et ille, quisquis ambitu liber, nec vana captans lucra, nec leves plausus, coelestiores excitatus ad curas In astra tendit et Deum studet nosse, qua Se Ipse pandit ambulatque suspensis periculosas gressibus per ambages, non mentientis fila persequens libri; 
Has an enemy sown destructive seed in the field of Christ some dark night? Or does an aggressive fury, which belongs to mortal humanity and a depraved mind, take any kind of nourishment, and does it involve man in the case of God? Or does the curious world suffer this punishment justly, while it allows nothing to remain hidden, and it is glad to pursue what is refused to be understood? Like that insolent crowd of old, builder of a haughty heap, went apart into a thousand languages, while it creates a road to heaven, and, as language loses its way, it laid aside the old treaty of speech. Oh, what are we at? We, that small group, chosen from all over the world, we are torn asunder, oh, terrible, again and again, and we are divided in discord, while the Moor laughs and the Jew rejoices.

(46) Blessed, uncomplicated religion, without artificiality, removed from the factions of the people, religion, which is certain that faults are washed away by the death of Christ, places hope and faith therein and believes that salvation is given for free to those who deserve punishment and applying the generous gift of holy love, religion does not concern itself with understanding the sublime, nor does it ask so much whether everything that is to happen comes by a certain law, in what way the Ruler, who has no share in evil, does want evil or does not want it or to what extent the highest cause restrains our will by a powerful nod.

(57) And blessed is he, whosoever, free from ambition and not in pursuit of vain profit or frivolous applause, urged on to more heavenly cares, reaches for the stars and applies himself to become familiar with God, where He reveals Himself in person, and he walks with subdued footsteps along dangerous detours, persistently following the threads of a book that does not lie, 
cui charitate temperata libertas certat manere dissidentibus concors; piaeque purus aequitatis affectus, damnatus aliis, ipse neminem damnat; modestiaeque limitem premens, donat nunc verba vero, nunc silentium paci. Haec saepe populo teste, saepe privatim, haec ipsa fato iam propinquus, Armini, adhuc monebas, cum laboribus vitae longis fatiscens, saeculique pertaesus fastidiosi, pertinacis, ingrati, indigniore parte fractus, et languens, 75 meliore sospes, illa millibus multis monstrata per te regna totus arderes. Et nunc paterno sidus additum templo Deum precaris, det gregi suo lucem, hic quanta satis est, hac det esse contentum, 80 det non loquentes sua reperta doctores, det consonantes semper omnium linguas, aut corda saltem, praepotente vi flammae caliginosas litium fuget sordes, ut spiret unum tota civitas Christi, vitamque terris approbet, fidem coelo.

67 neminem] nimium P.C. 1639 London (v. 65) 68 limitem] limites Bertius 73 saeculique] saeculisque P.C. 16451670 (v. 71) 77 totus] solus Bertius 84 fuget] fulget P.C. 1639 London (v. 82) 
whose freedom, moderated by grace, exerts itself to stay in harmony with those who disagree and pure in his inclinations to merciful fairness, even if he is condemned by others, he himself condemns no one and pressing the border of modesty, he now lends words to the truth, now silence to peace.

(70) It was these things that you used to recommend, close to your death already, Arminius, often in the presence of the people, often in private, when, getting tired by the long labours of your life and revolted by our time, which is disgusting, inflexible and unpleasant, your lesser part broken and getting weak, your better part unscathed, you desired ardently with all your heart that realm, which through you has been shown to the countless throngs. And now, as a star added to the paternal temple, you beseech God to give light to his own flock as much as is necessary here on earth, to give contentment about the light, to give masters who do not speak about their findings, to give that the tongues of all people, or at least their hearts, always resound harmoniously, by the supreme power of the flame, may He drive away the murky refuse of quarrels, so that the whole community of Christ breaths one spirit, and approves of life on earth and faith in heaven. 



\title{
CHAPTER SEVEN
}

\section{MANUSCRIPT PAMPHLETS AND MADE-UP PERFORMANCES: NEW SOURCES AND CHALLENGES IN THE STUDY OF PUBLIC OPINION}

\author{
Nelleke Moser
}

\section{INTRODUCTION}

According to Habermas, the process of formation of public opinion was steered mainly by the printing press. Printed chronicles, newsletters and pamphlets would form the kind of printed news supply that is generally assumed to have fuelled discussions, helping people to form an opinion and to reach consensus on a given issue. However, more recently it has been acknowledged that public opinion was not only formed by printed information that was published periodically. Opinions were also shaped through visual, oral and manuscript media, and the dividing line between public opinion and the point of view of an individual or an elite is more difficult to establish than Habermas would have us believe. Historians have recently become more aware of the dynamics of public opinion, of the various levels on which such an opinion might be formed and of the different media that come into play, especially when discussing the early modern period. ${ }^{1}$

In this respect, two types of sources in particular deserve our attention: manuscripts and performances. ${ }^{2}$ Both of them allow for new questions and both imply new challenges. Archives and libraries are booming with early modern manuscript material that has not been studied systematically so far, for want of an inclusive catalogue. ${ }^{3}$

\footnotetext{
${ }^{1}$ For a more elaborate discussion of recent reactions to Habermas's idea of 'public sphere' and formation of opinion and its adaptation for the early modern period, see the introductory chapter to this volume by Jan Bloemendal and Arjan van Dixhoorn.

${ }^{2}$ Cf. Marotti \& Bristol, Print, Manuscript, Performance; Bouza, Corre manuscrito.

3 The Bibliotheca Neerlandica Manuscripta (BNM) focuses on mediaeval and late mediaeval manuscripts, and the Short Title Catalogue Netherlands (STCN), the Dutch retrospective bibliography for the period $1540-1800$, only includes printed books. A Dutch equivalent of the Catalogue of English Literary Manuscripts 1450-1700 (CELM) is much called for.
} 
Manuscripts promise to shed new light on the process of formation of opinion because they frequently served to distribute suspicious or subversive texts, and handwritten sources would speak more freely and unequivocally than printed media about issues that were causing tension within society. Although some have suggested that manuscripts would only have a limited impact on public opinion because they were circulating among a very restricted audience, others have pointed out that manuscript news sometimes even enjoyed a wider distribution than printed texts. ${ }^{5}$ Manuscript sources therefore certainly deserve further investigation. As for performances, the interaction between theatre and formation of opinion has been studied more thoroughly, especially when it comes to the role of drama in the spread of the Reformation. ${ }^{6}$ Drama, like sermon, was effective in conveying messages to a live audience, and the moral, social and theological questions raised in rhetoricians' plays were a proper onset for debates and formation of opinion. $^{7}$ Another promising line of research involves the interaction between theatre plays and news media, such as pamphlets and newsletters, and the measure in which the representation of recent events is shaped by literary conventions and/or propaganda intentions. ${ }^{8}$ The main issue with studying performances, however, is that the event itself is long gone. If anything, all we have is a written record: the text of a play, or an eyewitness account of the performance. Either way the relation between the written version and the play as it was performed must be treated with caution, for the impact and function of the performance may differ drastically from the impact and function of the text, whether it is a manuscript copy or a printed edition. ${ }^{9}$ Further research is needed on how to use and interpret written and printed records of drama in the study of formation of public opinion.

By discussing a source that represents both manuscript and performance, this article focuses on this more dynamic, multi-layered view of public opinion and on the challenges of method and epistemology

\footnotetext{
${ }^{4}$ Bouza, Corre manuscrito, pp. 63-67; Marotti, Manuscript, Print and the English Renaissance Lyric, pp. 75-134; Spaans, 'De pen als wapen?', p. 99.

${ }^{5}$ On the restricted reach of manuscript texts: Spaans, 'De pen als wapen?', p. 99. On the broad distribution of manuscripts: Woudhuysen, Sir Philip Sidney and the Circulation of Manuscripts, pp. 148 and 151; Bouza, Corre manuscrito, pp. 16-19 and 38-41.

${ }^{6}$ Pettegree, Reformation and the Culture of Persuasion; Waite, Reformers on Stage.

7 Van Bruaene, Om beters wille; Van Dixhoorn, Lustige geesten.

${ }^{8}$ Groenland, 'Toneel als pamflet', p. 38; Levy, 'Staging the News'.

9 Van Bruaene, 'Printing Plays'; Chartier, 'Copied onely by the eare'.
} 
with which students of literary texts are confronted when they set out to study the interaction between literature and public opinion. My aim is to unravel the interplay between fact and fiction, between historical and literary sources in the process of formation of opinion, and to point out the problems encountered in this attempt.

The source under consideration in this article is an incomplete, handwritten description in Dutch of a theatrical performance that took place in Madrid in 1623 before members of the Spanish royal family and Charles, Prince of Wales. ${ }^{10}$ Prince Charles (the son of James I of England) had visited Madrid unexpectedly in order to arrange a wedding between himself and the Infanta María, the sister of Philip IV, King of Spain. Negotiations about a marriage between an English prince and a Spanish princess had been initiated long before. ${ }^{11}$ Charles tried to speed things up by travelling incognito to Madrid together with the Duke of Buckingham. Charles's efforts were to no avail, for after months of diplomatic negotiations and royal entertainment, the Prince returned to London without a bride. According to the manuscript account, the subject matter of the play performed before the royal audience was the Battle of White Mountain in 1620. In 1619, the Elector Palatine Frederick V had taken up the position of King of Bohemia, encouraged by rebellious Protestants who conducted a revolt against the Catholic King Ferdinand II. Frederick's royal position only lasted one winter (hence his derisory title 'the Winter King') and came to an end when his army was defeated by the Habsburg army of Ferdinand II in the Battle of White Mountain near Prague in 1620. Frederick and his wife Elizabeth (the daughter of King James I of England) were expelled. They found refuge in the Dutch Republic, the country of his grandfather William of Orange. From 1621 onwards, they resided in The Hague. ${ }^{12}$

The account of the performance in itself is a unique and intriguing document. It was unknown to scholars studying the Spanish Match until now, and new discoveries of sources concerning the match are

${ }^{10}$ The manuscript is preserved in the Regionaal Archief Leiden, The Netherlands, ms. 72422 portefeuille folio.

${ }^{11}$ They first involved Prince Henry and the infanta Ana, in 1604. When Henry died in 1612, in 1614 new plans were made involving Prince Charles and the infanta María. Redworth, The Prince and the Infanta, pp. 7, 10, 16; Cogswell, Blessed Revolution, p. 18; Pursell, The Winter King, p. 55.

${ }_{12}$ Pursell, The Winter King. 
fairly rare. ${ }^{13}$ Moreover, it is the only source so far that offers a minute description of a play that was witnessed by the Prince of Wales during his visit. ${ }^{14}$ But rather than providing any long-awaited answers, the document instead gives rise to a whole host of unanswerable questions on its origin, function and reliability. Most of all, it is debatable whether this is a true description of a real play that was performed during the visit of Prince Charles to Madrid. None of the secondary sources on contemporary Spanish theatre that I consulted in preparation for this article produced any reference to (let alone the full text of) the play that is described in the account. ${ }^{15}$ Perhaps there never was a play on the Battle of White Mountain-perhaps the mere idea of playing out this historic confrontation between Frederick and Ferdinand on stage before the eyes of the Prince of Wales during his visit to Madrid was deemed useful for polemic purposes in 1624. Therefore, rather than a problematic opportunity to fill a lacuna in what is known about the Spanish Match, it is its polemic function that makes this newly discovered source valuable and challenging at the same time.

As such, the manuscript account unites two historic events that were the talk of all Europe at that moment. This connection elicits attention. Traditional historiography has it that James I supported the Spanish Match because he was hoping that an English-Spanish bond would help his daughter and son-in-law to regain the lands they had lost to the Habsburg Emperor in $1620 .{ }^{16}$ According to this view, when it transpired that the Spanish would never condone such a develop-

${ }^{13}$ As Glyn Redworth wrote when presenting three unknown letters by James I and the Prince of Wales: 'Comparatively little additional material concerning the Spanish Match has come to light since S.R. Gardiner's compendious investigations in the last century' (Redworth, 'Of Pimps and Princes', p. 401).

${ }^{14}$ Cruickshank, 'Calderón's Amor, honor y poder and the Prince of Wales', p. 76: 'Unfortunately, not one correspondent mentions any play by name, despite regular performances'; Robbins, 'The Spanish Literary Response to the Visit of Charles', p. 107: 'Unfortunately, it is not clear what specific plays the Prince actually saw, though Don Cruickshank has suggested that Pedro Calderón de la Barca's play Amor, honor $y$ poder [...] may have been seen by the Prince of Wales'.

${ }^{15}$ Shergold and Varey, 'Some Palace Performances of Seventeenth-Century Plays'; Shergold, A History of the Spanish stage; González Gutiérrez, El Teatro Escolar de los Jesuitas; Sánchez Cano, 'Entertainments in Madrid'; Ettinghausen, 'The Greatest News Story'; Robbins, 'The Spanish Literary Response to the Visit of Charles'. I thank Alexander Samson (University College London), Leticia Alvarez Recio (Universidad de Sevilla) and Don Cruickshank (University College Dublin) for confirming that they do not know of any play on the Battle of White Mountain being performed in Madrid in 1623 .

${ }_{16}$ Pursell, 'The End of the Spanish Match', pp. 700-01. Also Levy, 'Staging the News', p. 254. 
ment, the negotiations for the marriage-which had already been hampered by religious differences-foundered altogether, much to the delight of fervent Protestants in England. Yet this 'consecrated view of the journey as a way of resolving the issue of the Palatinate' has been criticized in the recent scholarly debate on the Spanish Match. ${ }^{17}$ An English endeavour to reinstate the power of the Bohemian king should no longer be considered as the main reason for this marriage, nor should the Spanish refusal be seen as the main reason for the failure of the match. ${ }^{18}$ Prince Charles and his companion, the Duke of Buckingham, merely used the Palatinate as an excuse in retrospect. ${ }^{19}$ Putting forward their frustration about not being able to help the Palatinate as the reason for their departure would not only camouflage their failure in bringing the Spanish Infanta to England, but also enabled them to claim a 'new status as religious heroes'. ${ }^{20}$

The study of this account suggests that even if there was no causal relationship between the defeat of Frederick $\mathrm{V}$ and the English attempts to secure a marriage between Charles and the Infanta, there seems to have been a connection between the two on a polemic level. It is this polemic level that will be central to the argument of this paper. The account may or may not offer insight into the propaganda with which the Prince of Wales was confronted during his visit (i.e. the supposed performance). However, it at least serves as a token of the polemics surrounding this event throughout Europe (i.e. the manuscript text). This makes this source an appropriate case for investigating some fundamental problems of the study of the role of literature in the process of the formation of opinion, particularly with regard to the function of the (at least to us) more ephemeral literary culture beyond the realm of the printing press. Instead of trying to find answers to any of the factual questions that the document provokes, in this article I will deal with a question of a more methodological nature: What is the status of this document (and other documents of a similar nature) as a source for understanding the interplay between literature and the early modern public opinion process?

\footnotetext{
17 Samson, The Spanish Match, p. 1.

${ }_{18}$ Samson, The Spanish Match, pp. 1-2; Redworth, The Prince and the Infanta, pp. 2-4, 7-8, 10, 16-17, 103, 111, 139; Cogswell, Blessed Revolution, pp. 17-18, 20; Pursell, The Winter King, pp. 55, 82; Redworth, 'Of Pimps and Princes', pp. 20, 22, 25, 56 and 403-04; Pursell, 'The End of the Spanish Match', pp. 714, 724-25.

${ }_{19}$ Pursell, 'The End of the Spanish Match', pp. 701, 711-12, 716-17, 720, 722-25; Redworth, The Prince and the Infanta, pp. 4-5, 89, 92, 106, 123, 130-33, 135-37.

${ }^{20}$ Redworth, The Prince and the Infanta, pp. 138-39.
} 
It goes without saying that even though this document is presented as a contemporary eyewitness account, this does not necessarily mean it is reliable or free from bias. In the first place, it is incomplete, which makes it difficult to interpret the text because essential information might be lacking. In the second place, it is impossible to tell whether this account should be considered as a factual description of a historical event or as a literary representation of an imagined event. Of course, the Battle of White Mountain is a historical event, represented on stage in a literary form, according to the account. But was the performance itself a historical event? As long as the reliability of the account is doubtful, we must consider the possibility that the description in itself is fiction. My final aim, however, is not to dismiss this source as unreliable, nor to find out what really happened in Madrid. I will not use the manuscript account as the authoritative source on a performance during Charles's visit, but I will weigh it against other relevant sources: descriptions of the events surrounding the Spanish Match as well as descriptions of early modern theatre performances in general. I will not automatically take it to be a factual account of the events in Madrid in 1623, but I will focus on what people thought was happening, or at least, what the reader of this manuscript text was made to think had happened. Firstly, I will describe the form and content of the manuscript text as it is preserved in the Regionaal Archief Leiden. I will then compare the description of this performance to other primary sources concerning the Spanish Match, covering three different types of media: printed pamphlets, theatre plays and manuscript reports of performances. I will focus on the ways in which these sources may have been used to fuel polemical discussions and stir public opinion by mixing fact with fiction and using literary techniques. Finally, I will evaluate what is to be gained from performances and manuscript sources when studying the interplay of literature and public opinion, and what pitfalls accompany this type of research.

\section{THE SOURCE UNDER SCRUTINY: QUESTIONING THE EYEWITNESS}

The account of the performance is a handwritten prose text on a folded folio sheet, housed in the Regionaal Archief Leiden. ${ }^{21}$ The

\footnotetext{
${ }^{21}$ Regionaal Archief Leiden, ms. 72422 portefeuille folio. See Appendix A for the full text in Dutch and my English translation.
} 


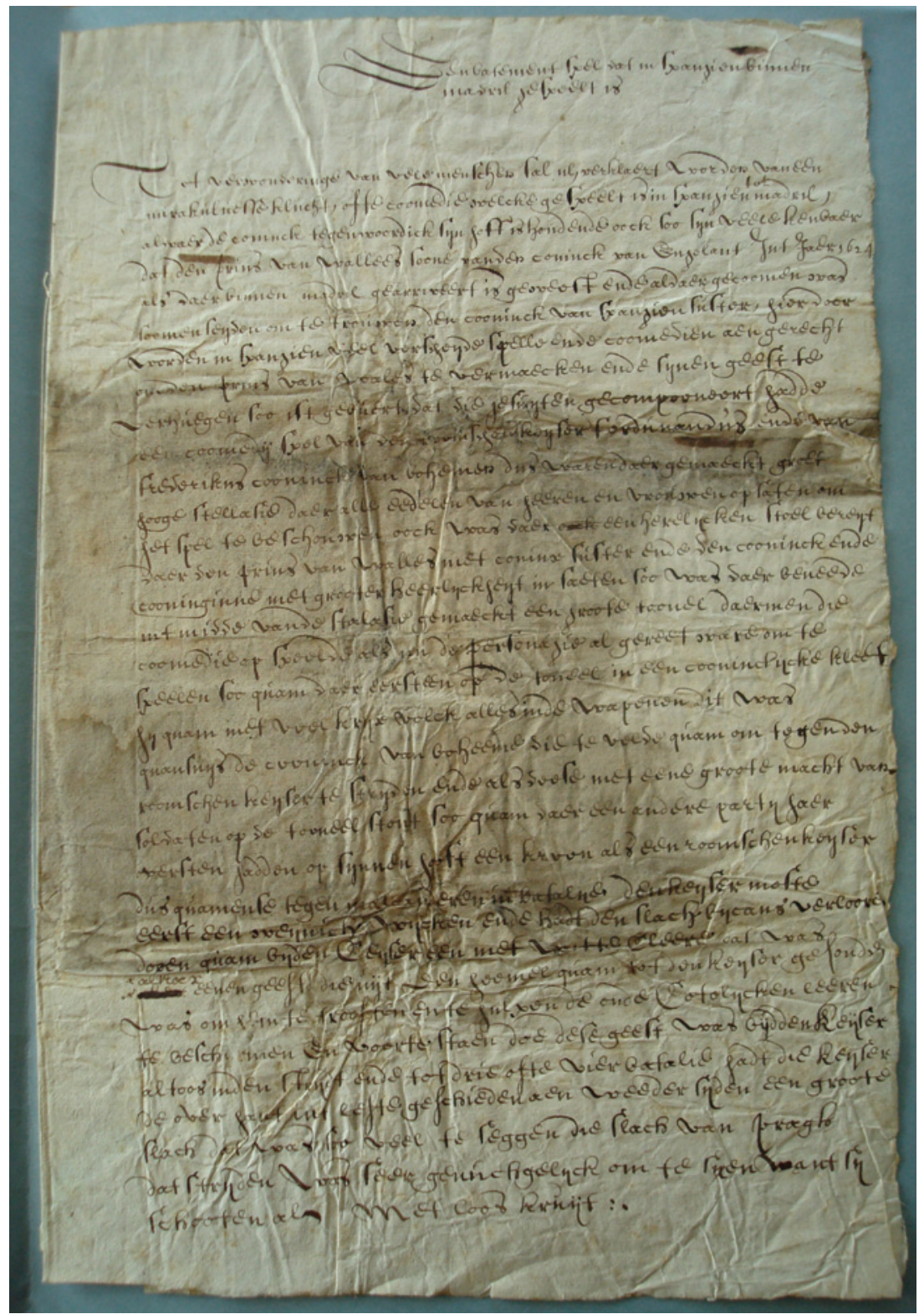

Ill. 1. RA Leiden ms. 72422 portefeuille folio, fol. 1r. With courtesy of the Regionaal Archief Leiden. 


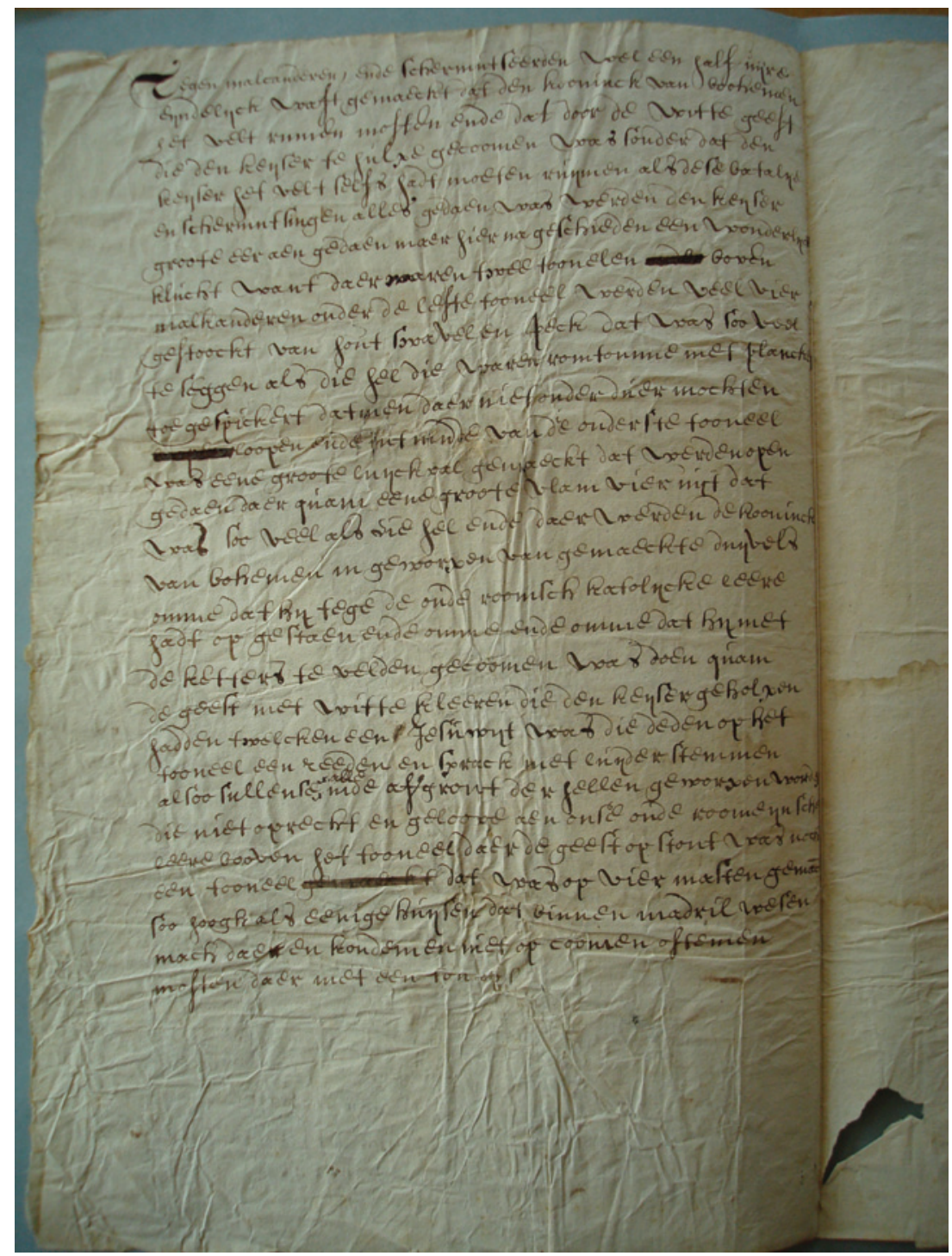

Ill. 2. RA Leiden ms. 72422 portefeuille folio, fol. 1v. With courtesy of the Regionaal Archief Leiden. 
archive did not keep a record of the manuscript's provenance. It is catalogued with assorted, unrelated material. In the past, it was catalogued together with literary texts from the same period. It is currently catalogued together with other sheets of the same format. In the very brief catalogue description it is wrongly dated around 1600. There is a thread in the central fold, which indicates that at some stage, it may have been bound together with other sheets. Wrinkles and creases in the folio sheet show that it has been folded several times. One of the folds indicates the left margin. Other folds suggest that the sheet was folded into a smaller, more manageable size after it had been written on. In this folded state, the document was exposed to influences from without, as moisture stains and darker parts on the outermost sides (fol. 1 recto and fol. 2 verso) demonstrate. The handwriting is regular and easily legible, although little attention has been paid to spelling and punctuation. Several errors were corrected by the same hand in the course of writing. Some of them indicate that the text may have been copied from another source (dittography, eyeskip). The text ends abruptly after the first letter of a new word, halfway through the verso side of the first leaf. The second leaf is blank on both sides. We will never know what happened to prevent the completion of the text. The scribe may have been interrupted or distracted. Another explanation might be that the original text was cut in pieces to allow different scribes to copy it at the same time. This was a common way for manuscript texts to be multiplied. ${ }^{22}$ The letter ' $s$ ', which is now the final one in the manuscript, may have been the final one at the very end of the page of the original text, or it may have functioned as catchword to facilitate the connection to the next part of the text. There is no mention of who wrote or owned this account, nor a date or place to indicate when or where it was written. The original text, title and author of the play are not mentioned either. The account only bears a rather general title indicating the content: 'A play that was performed in Spain in Madrid'. In the first line, the text addresses an unspecified

\footnotetext{
${ }^{22}$ Levy, 'Staging the News', p. 265, refers to a newsletter writer who, upon receiving 'a particularly rare tract' from a friend, 'cut it in pieces and set three of his students to transcribe it in enough copies to satisfy all his curious correspondents'. The copying of separate gatherings by different students to speed up the process of transcription (copying 'a pecia'), is also mentioned by Bouza, Corre manuscrito, p. 37.
} 
audience: 'You will hear the story of a miraculous farce or comedy that will astonish many people'. ${ }^{23}$

In sharp contrast to the lack of information on its origins, the account gives an impressive amount of information on the event it describes. The source tells us exactly how the stage was set up and what was happening on stage, thereby enabling us to obtain a clear impression of the performance as a whole. First of all, the festive occasion is specified: the play was performed when Charles was visiting Madrid in 1624, 'allegedly' in order to arrange a wedding with the Spanish Infanta, 'as many people know'. (Of course, the visit took place in 1623-the mistake in the year of the visit might mean that the account was written (or copied) in 1624.) According to the author of this account, many performances were staged for the prince's entertainment, and it was Jesuits who composed this particular play about the Roman Emperor Ferdinand and Frederick, the King of Bohemia. It should be noted that the setting and the choice of subject matter differs greatly from the usual Jesuit theatre, which was written and performed in Latin, functioned mainly within the framework of Jesuit colleges, and mostly dealt with biblical subject matter. Admittedly, Jesuits wrote occasional plays to welcome important persons, and a small number of Jesuit plays in the seventeenth century were based on recent events. ${ }^{24}$

The content of the play is described in quite some detail. First, the King of Bohemia appears on stage, accompanied by armed soldiers. Then another army enters, preceded by the Emperor Ferdinand. They start to fight, and the 'battle of Prague' is portrayed on stage, including a shooting match with blank cartridges which lasts for half an hour (described as 'pleasant to witness'). There are several moments of suspense and indecision, before a figure called Xaltrax descends from heaven, dressed entirely in white, and helps Ferdinand to win the battle. This is another remarkable detail in the description. It is rather unlikely that the Jesuits would have used a mysterious, almost pagan, character like Xaltrax. He need not have been an entirely fictional invention though. According to historical descriptions of the battle, '[t]he Emperor's side also benefited from the exertions of a Carmelite friar whose ecstatic exhortations may have significantly bolstered

${ }^{23}$ Quotes refer to the Dutch text and the English translation, both in appendix A.

24 González Gutiérrez, El Teatro Escolar de los Jesuitas, pp. 212 and 279, p. 206. 


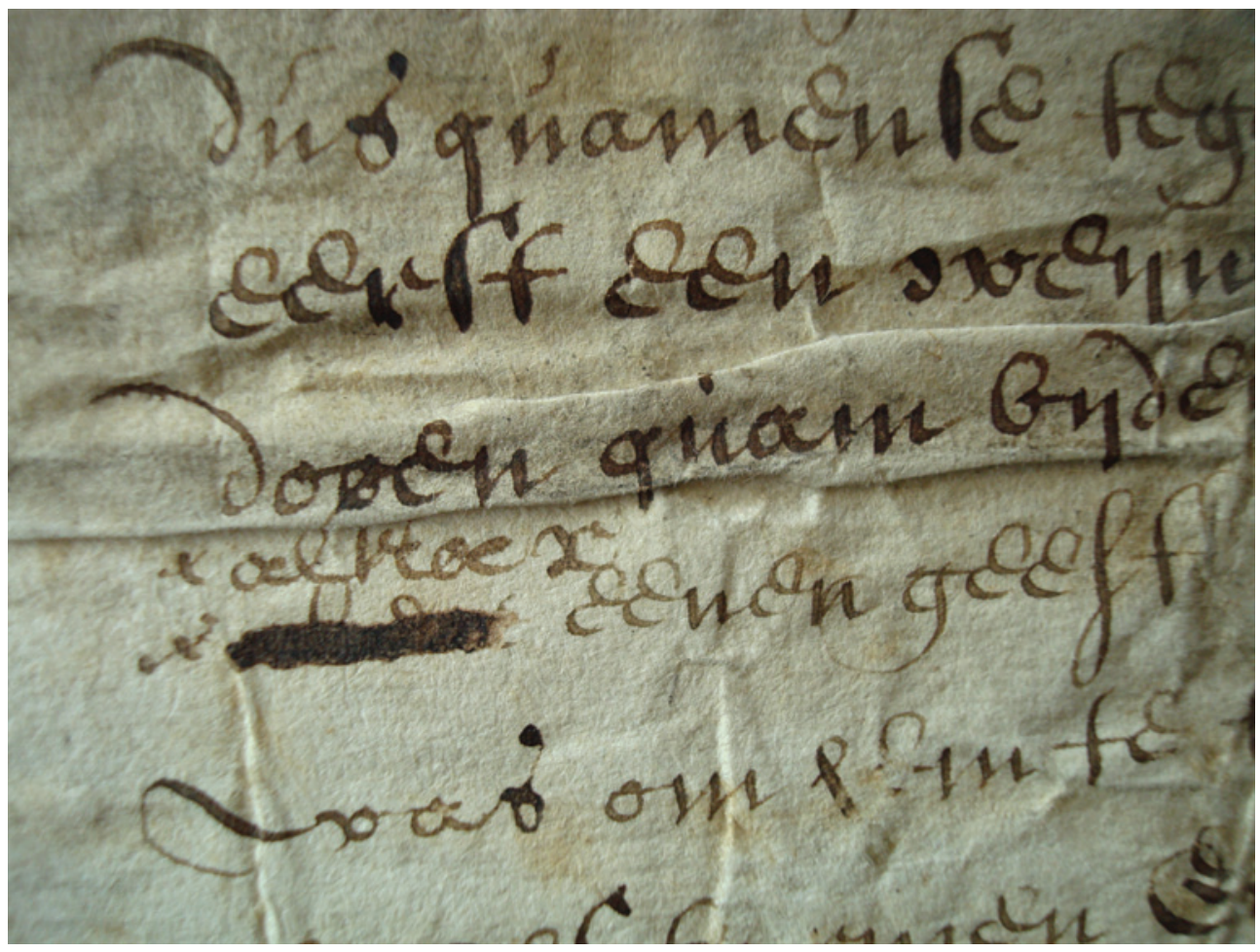

Ill. 3. RA Leiden ms. 72422 portefeuille folio, fol. 1r (detail: Xaltrax). With courtesy of the Regionaal Archief Leiden. 
morale' ${ }^{25}$ Xaltrax may have been modelled after this Carmelite friar, wearing a white cloak. But he would have been a figment of the imagination of the person who wrote the account, rather than a character that the Jesuits would use in their plays.

After the victory onstage, Ferdinand is greeted by rapturous applause. But the story does not end there. An epilogue (described as 'a miraculous farce') has a number of devils throw Frederick into hell through a trapdoor in the lower stage, under which a real fire is burning. Finally, the figure representing Xaltrax (played by a Jesuit, as the author of the account remarks) takes to the stage again and declares in very strong terms that this is the fate of anyone who fights against the Roman Catholic religion. It was common for Jesuit plays to be concluded with an epilogue, resuming the general message of the play. ${ }^{26}$ The plot in itself, featuring Catholics fighting Protestants and sending them off to hell, was used by Catholic authors on different occasions. Already in 1597, Jesuits in Munich performed a similar play dealing with the battle against heresy, representing three hundred devils who would throw themselves from the scene straight into hell. ${ }^{27}$ In 1621, the same topic features in a poem in a Dutch news message on the Battle of White Mountain, describing how the Habsburg army, assisted by heavenly powers, chases the Protestant army away, into the 'dark house of Pluto'. ${ }^{28}$ Jesuits had a good reason to be critical of Frederick of Bohemia. The Bohemian Protestants considered the Jesuits to be the greatest threat to Protestantism and to have far too much influence on Ferdinand..$^{29}$ In a letter from 1619, Frederick blamed the Jesuits for attempting to bring Bohemia 'totally once again under the Papist yoke and an absolute dominion'. ${ }^{30}$ As a result, the Jesuits suffered from the Protestant rebellion in the Palatinate more than anyone else and when the Protestants came into power in Bohemia, the Jesuits were expelled and dispossessed, and some of their churches were subjected to iconoclasm and reform. ${ }^{31}$ Obviously, the Jesuits would hold a grudge against Bohemian Protestants and Frederick in particular. On the other hand,

${ }^{25}$ Pursell, The Winter King, p. 115; Pursell refers to Olivier Chaline, La Bataille de la Montagne Blanche (8 Novembre 1620): Un mystique chez les guerriers (Paris 2000).

${ }^{26}$ González Gutiérrez, El Teatro Escolar de los Jesuitas, pp. 220-21.

27 Ibidem, p. 271.

${ }^{28}$ Sabbe, Brabant in 't verweer, p. 78.

${ }_{29}$ Pursell, The Winter King, pp. 19, 45, 53, 66-68, 75, 85.

${ }^{30}$ Ibidem, p. 84.

${ }_{31}$ Ibidem, pp. 48, 59, 95-96. 
it seems that the Jesuits were 'vociferous in their support for the marriage' between Charles and the Infanta, since they were positively disposed to the thought of having a Catholic queen in England. ${ }^{32}$ They would not have jeopardized that opportunity by rubbing Charles up the wrong way.

The account also includes a detailed description of the stage and the gallery. The audience was seated on a high gallery, where a special place was designated for the Spanish royal family, as well as for the Prince of Wales. The prince is described as sitting together with the sister of the king, i.e. the Infanta María whom he sought to marry. However, it is not very likely that the Prince of Wales would watch a performance in the open air, seated next to the Infanta. When Charles first arrived in Madrid, the prince and princess were not allowed to be in each other's company. Only when Charles had agreed to the Spanish conditions (including full liberty for Catholics in England) were they allowed to see each other in public. Much to the surprise of the Spanish, Charles agreed to the new conditions on 7 July $1623 .{ }^{33}$ On the same day Charles wrote a letter to his father, saying that the Infanta 'sits publicklie with me at the Playes'. ${ }^{34}$ This would mean that the situation as described in the account of the performance is not impossible, and if the performance were real, that it took place after 7 July 1623 . Yet the royal family would watch performances inside the palace, rather than in the open air.

The gallery surrounded a large stage, consisting of two levels, an upper stage and a lower stage. The lower stage featured a trapdoor, which proved to be essential in the play's epilogue. To prevent people from walking underneath the lower stage, carpenters had fitted wooden boards all the way around. The upper stage was as high as some houses in Madrid and could only be reached by taking a rope and jumping onto it. It is hard to tell what purpose this upper stage would have served, as this is where the account abruptly ends. In itself, the technique of the two levels and the trapdoor in the stage construction to create special effects, such as falling and rising, was not new. It had already been introduced in the autos sacramentales (moralities or

\footnotetext{
${ }^{32}$ Redworth, The Prince and the Infanta, pp. 117, 46.

${ }^{33}$ Pursell, 'The End of the Spanish Match', p. 714; Cruickshank, 'Calderón's Amor, honor y poder and the Prince of Wales', pp. 85-86; Sánchez Cano, 'Entertainments in Madrid', pp. 63-64; Redworth, The Prince and the Infanta, pp. 123-24.

${ }^{34}$ Cruickshank, 'Calderón's Amor, honor y poder and the Prince of Wales', p. 77.
} 
biblical plays organized by the church) of the sixteenth century. ${ }^{35}$ It is therefore possible that such a stage would have been used in Madrid in 1623 as well, but this is not confirmed by other sources that describe the stage setting of the plays performed on that occasion. ${ }^{36}$ As these plays were performed either inside the palace or outside on a wagonstage (during the entry and the procession), none of these match the two-levelled stage of the play on the Battle of White Mountain. The stage that comes closest to the one described in the Dutch account is the one on the Plaza Mayor, which in a similar way was surrounded by balconies and closed off by carpenters with wooden barriers when a festival took place. The difficulty, however, is the scale and the purpose of the Plaza Mayor, which could host up to 50,000 spectators and was mostly used for bullfights and games, not for theatre performances. ${ }^{37}$

Detailed as the description of the play may be, it evokes more questions than answers. Bearing in mind that the play was performed in front of Charles, the choice of the subject matter is remarkable to say the least. Throwing Frederick into hell before the very eyes of his brother-in-law almost seems too blunt to be true. If not the Jesuits, who would have been so daring as to stage such subject matter, and with what intention in mind? Who was the author of the play? Who performed it? What was the purpose of this performance? How would it have been received by the English prince and how did the play's reception influence the negotiations for the Match? What member of the audience was responsible for the description of the play, and why did he or she decide to take notes? In what language was the play performed, and in what language was the description written? Who made the manuscript copy of the account and what was the intended audience? Why does it suddenly end in mid sentence? It is well-nigh impossible to answer these questions without ending up in mere speculation, for the account itself offers no clues whatsoever to its origins, goals or reception. To find out who might have written the account of the performance would require a thorough investigation into the members of the English or Spanish royal entourage (diplomats, noble-

\footnotetext{
${ }_{35}$ Alonso Hernández, Spaanse letterkunde, pp. 193-94 and 200.

${ }^{36}$ Shergold, A History of the Spanish stage, pp. 266, 294 and 625 (illustration); Sánchez Cano, 'Entertainments in Madrid', pp. 55, 71 and plate 13; Cruickshank, 'Calderón's Amor, honor y poder and the Prince of Wales', pp. 76-77. The engraving is also shown on: http://www.theatrales.uqam.ca/chronologie/madrid.html (last consulted on 20 March 2009).

37 Sánchez Cano, 'Entertainments in Madrid', p. 60.
} 
men), professional and private news writers that were present, as well as actors and playwrights involved in the entertainment for the Prince. Finding the scribe who made this copy would entail comparing this handwriting to other written material of the period-but where to begin? Searching for possible readers of this manuscript text would be like looking for a needle in a haystack as well. The research is further hampered by the fact that the original text may not have been written in Dutch, but in Spanish or English, and translated into Dutch later on. ${ }^{38}$ Last but not least, how can we even be sure that this performance took place in reality?

All of this leaves us with a great many riddles. For want of other evidence on the play of the Battle of White Mountain, all we can do is compare this source to other sources bearing on the same event. First of all, I will focus on printed pamphlets and newsletters relating to the Spanish Match. Pamphlets come in different shapes and styles: usually brief, but sometimes bulky, fictional as well as matter-of-fact, satirical as well as serious, in prose as well as in other literary forms (poems, dialogues, fictional letters), with and without illustrations. ${ }^{39}$ Newsletters developed from personal correspondence into a professionalized trade, which was flourishing around $1620 .^{40}$ In Spain, a particular type of newsletter was known as relaciónes, which were reports that covered a single event. ${ }^{41}$ All of these could circulate in print as well as in manuscript, whether they were copied from a printed version or published in manuscript form straight away. ${ }^{42}$

As has been pointed out in the introduction to this article, the representation of the course of events in printed sources may differ from the one in manuscript sources. This is why we will now have a closer

\footnotetext{
${ }^{38}$ News travelled throughout Europe in different languages and translations. On the exchange between the Low Countries and England: Levy, 'Staging the News', pp. 266-67. On the exchange between Spain and England: Samson, '1623 and the Politics of Translation'.

${ }^{39}$ De Kruif, Meijer Drees and Salman, Het lange leven van het pamflet; Harline, Pamphlets, printing and political culture.

${ }^{40}$ Levy, 'Staging the News', pp. 263-65.

${ }^{41}$ Rodríguez Pérez, De Tachtigjarige Oorlog in Spaanse ogen, p. 24; Ettinghausen, 'The Greatest News Story', p. 76.

${ }^{42}$ The circulation of news in manuscript form is mentioned in Woudhuysen, Sir Philip Sidney and the Circulation of Manuscripts, pp. 148 and 151, Levy, 'Staging the News', pp. 254 and 264-65, Bouza, Corre manuscrito, pp. 31-41, Ettinghausen, 'The Greatest News Story', p. 76, Rodríguez Pérez, De Tachtigjarige Oorlog in Spaanse ogen, p. 170, Fox, Oral and Literate Culture, pp. 368-70 and 412-13.
} 
look at the printed pamphlets on the Spanish Match, comparing them with the manuscript account.

\section{Printed Pamphlets on the Spanish Match: DEMONSTRATIONS OF DIPLOMACY}

Ettinghausen once called the story of Charles travelling incognito and arriving unannounced in Madrid 'the scoop of the century', and even 'the greatest news story since the resurrection'. ${ }^{43}$ A large number of pamphlets, newsletters and relaciones in manuscript and print covered the visit of the Prince of Wales to Madrid in 1623.4 According to Sánchez Cano, thanks to these publications, the festivities organized to entertain the Prince of Wales 'were played out before the public, not just of the urban populace in Madrid, but also before the wider public sphere'. ${ }^{45}$ They may be considered as 'textual counterparts' of the festivities. ${ }^{46}$ The reports offer what seems to be an accurate, day-to-day account of the negotiations and the meetings of the English guests and their Spanish hosts, describing various forms of entertainment, from hunting wolves to a display of armour, visits to Casa del Campo, walks along the river and fireworks, music, dance and theatre performances. However, none of the pamphlets describe the title or content of any of these plays, leaving us empty-handed when it comes to establishing a performance of a play on the Battle of White Mountain.

Instead of discussing the details of the entertainment, the pamphlets and reports focus on the way Charles and Philip IV treated one another in a mutual display of discretion, courtesy and tactics. It has been suggested that the Spanish pamphlets and relaciones on the Spanish Match served to glorify the Habsburg monarchy and 'functioned

\footnotetext{
${ }^{43}$ Ettinghausen, 'The Greatest News Story', p. 89.

${ }^{44}$ English and Spanish printed pamphlets on the Spanish Match can be found online in 'Renaissance festival books' from the British Library and in 'TEMPO: The early modern pamphlets online'. For Dutch printed pamphlets see Knuttel 1978 and the online source Digitale Atlas Geschiedenis (DAG). For manuscript copies of Spanish relaciónes and English verse libels on the Spanish Match, see Ettinghausen, "The Greatest News Story', pp. 78-79 and Early Stuart Libels, 'N.The Spanish Match Crisis, ca. 1618-1623'. Cf. Fox, Oral and Literate Culture, pp. 350, 388, 397-98 for separate mentions of the Spanish Match.

${ }^{45}$ Sánchez Cano, 'Entertainments in Madrid', pp. 73 and 51.

${ }^{46}$ Samson, The Spanish Match, p. 4.
} 
as religious propaganda for a European-wide Catholic audience ${ }^{47}$ In doing so, they apparently chose to demonstrate the moral standards and superiority of the Spanish rather than to seek a hostile confrontation. The pamphlets that describe the events during Charles's stay constantly emphasize the friendly manner in which the prince was treated by the Spanish. As Brennan Pursell writes, 'in ceremony Felipe treated Charles with the utmost honour'. ${ }^{48}$ According to Jeremy Robbins, most Spanish poems on the visit of Charles were similarly amicable in tone, driven by 'a desire not to offend', 'avoiding political comment' and emphasizing 'the friendship and equality between Philip and Charles' ${ }^{49}$ When Charles witnessed the procession of the penitents on Good Friday, the Count of Olivares, who held a powerful position at the Spanish court and who played an influential role in the wedding negotiations, took care that it would not 'offend the sensibilities of the English, ordering that anything that might cause either hilarity or offence be removed from the floats'.$^{50}$ According to an English pamphlet, Charles was 'continually from time to time exceeding much caressed and esteemed by that King, who delighteth extremely in his company, and greatly honoured by all the Court for his brave and Prince-like Comportments'. ${ }^{51}$ A Dutch pamphlet that was translated from the English describes how on one of their first meetings the King embraced the Prince, and gave many demonstrations of his love and affection, as well as of the tight bonds of trust and favour between the King and the Prince. ${ }^{52}$ Apparently, authors on both sides were aiming at a friendly representation of the rapport between the two countries. Such 'display of friendship' would indeed serve as 'a diplomatic tool' in royal circles at that time. ${ }^{53}$

Of course, the representation of events in the pamphlets does not necessarily imply a true or full account of what happened during Charles's visit to Madrid. It was not uncommon to leave out certain

47 Samson, The Spanish Match, p. 4.

48 Pursell, 'The End of the Spanish Match', p. 706.

49 Robbins, 'The Spanish Literary Response to the Visit of Charles', pp. 108 and 112.

50 Ettinghausen, 'The Greatest News Story', p. 82. Redworth, The Prince and the Infanta, pp. 90-91 also mentions a concern not to offend Charles and Buckingham on two occasions, although he also writes that 'the Spaniards onely rarely managed to show any respect for the religion of their guests'.

${ }^{51}$ A continuation of a former relation [...], p. 18.

52 Een waerachtich verhael ende journael [...], fol. A3 recto.

53 Redworth, The Prince and the Infanta, p. 27. 
details in the reports when they would not serve the ideological purposes of the text, the authors being very well aware of the pamphlets' 'capacity to manipulate and transform public opinion'. ${ }^{54}$ It is known that not all sources were equally diplomatic. The poet Antonio Hurtado de Mendoza, for example, wrote a sonnet on the occasion of Charles kneeling before the monstrance in the Corpus Christi procession (an event that convinced the Spanish of his willingness to convert to Catholicism). In the poet's eyes, this was a greater victory over 'fierce heresy and German error' than Charles V had ever managed to bring about. This poem seems to be an exception, as Jeremy Robbins writes: 'Here we do see a Spaniard forcibly expressing the superiority of Catholicism, something that is unusually partisan in comparison with the majority of poems written on Charles' visit'. ${ }^{55}$ Such negative opinions on 'heresy' may deliberately have been excluded from the pamphlets, which might explain why the contents of the theatre plays are not mentioned in them. Therefore, although the existence of the play on the Battle of White Mountain is not corroborated by printed pamphlets, neither does its absence from them constitute proof that there was never such a play.

It is clear that the representation of events in the printed pamphlets was much more diplomatic than is suggested by the manuscript description of the play on the Battle of White Mountain. But what about the actual plays? Although none of the printed pamphlets describe the theatre plays in detail, a number of the plays that were written especially for the Spanish Match have been preserved. They form part of propaganda campaigns, steered by the governments of both Spain and England. In the next section, I will discuss these plays and compare them to the play on the Battle of White Mountain as it is described in the manuscript account.

\section{Theatre Plays on the Spanish Match: SPELLING IT OUT ON STAGE?}

When Charles arrived in Madrid in 1623, the Count of Olivares was in the midst of conducting a grand campaign to restore the glory and

\footnotetext{
${ }^{54}$ Samson, ' 1623 and the Politics of Translation', p. 101; see also Levy, 'Staging the News', pp. 253-54.

${ }_{55}$ Robbins, 'The Spanish Literary Response to the Visit of Charles', p. 113.
} 
reputation of Spain. ${ }^{56}$ His aim was to reform and unify the nation. Following the example of Maravall, Rodríguez Pérez describes the efforts of Olivares in terms of a 'cultura dirigida', in which power and ideology are combined. By using propaganda, Olivares and his helpers did their utmost to convince the general audience that Spain was highly successful in national and international matters. One of the means employed by Olivares to boost Spain's reputation and self-esteem was theatre. Rodríguez Pérez argues that theatre was an unparalleled medium for shaping public opinion and was used in this period by the King and his entourage, who wanted to fashion a profitable image of Spain by fuelling the audience's belief in 'the high destiny of Spain'. ${ }^{57}$ The court was keen to make use of the talents of playwrights by commissioning plays on various occasions. In 1621, when the war with the Dutch Republic was resumed after the Twelve Years' Truce, a new type of comedias was introduced that suited the propagandistic projection of the self, displaying an optimistic and euphoric image. Military confrontations were once again being performed on stage without any restrictions, as they had been at the beginning of the war. Unsurprisingly, the topics of these plays include recent Spanish military victories, as described in accounts that were published soon after the events. ${ }^{58}$ In many plays the enemy is depicted as hostile and despicable. ${ }^{59}$ Some of them include explicit messages in favour of Catholicism. ${ }^{60}$ Interestingly, Rodríguez Pérez points out that the influence of Olivares is discernible in a number of these plays. Evidence that the court approved of the plays' representation of events is also to be found in the paintings at the palace of El Retiro, which depicted scenes from the battles and were inspired by the theatrical performances. ${ }^{61}$

Not only did the court use theatre as a propaganda machine to boost the country's confidence, but it also used theatre to steer public opinion on the Spanish Match in particular. There were several plays that dealt with the topic of the Spanish Match itself, which expressed a (negative) opinion on the matter and which were commissioned by noblemen with ties to the court. Most of them were written before or

${ }^{56}$ Rodríguez Pérez, De Tachtigjarige Oorlog in Spaanse ogen, p. 146.

${ }^{57}$ Ibidem, pp. 149-50.

58 Ibidem, p. 150.

${ }^{59}$ Ibidem, p. 184.

${ }^{60}$ Ibidem, pp. $180-81$.

${ }^{61}$ Ibidem, p. 150. 
after Charles's visit to Madrid, while one was presumably performed before his very eyes. In 1617, when the negotiations regarding a match between Charles and a Spanish princess were well underway, the Duke of Lerma (Olivares's predecessor) commissioned Luis Vélez de Guevara to write El caballero del sol. According to Cruickshank, 'the play ends by suggesting that some other princess would be a more appropriate match for the prince, a message that Lerma certainly wanted to communicate'. ${ }^{62}$ Lerma, however, wanted to prevent the English envoy Sir John Digby (who was in Spain to negotiate the marriage) from seeing the play. Cruickshank concludes that '[c]onceivably he felt that the play made this point with insufficient tact'. ${ }^{63}$ Here we see the same diplomatic consideration that was of a piece with the printed pamphlets-in spite of the critical tone of the play itself. Later theatre plays, however, seem to have bothered less with tact, aiming to get the critical message across unequivocally to the other party. In 1623 , Calderón wrote a play called Amor, honor y poder. ${ }^{64}$ It was performed in the old royal palace in Madrid on 29 June $1623 .{ }^{65}$ According to Cruickshank this play was commissioned by the court especially for the visit of the English prince, who may have attended this performance. ${ }^{66}$ It is likely that Calderón owed this commission to Olivares, who was related to Calderón's employer. ${ }^{67}$ Calderón's play is set in England in the fourteenth century, and the subject matter is the love between Edward III, King of England, and the daughter of the Earl of Salisbury, while the sister of the English king is courted by a foreign prince. The characters in the play can be easily identified as Prince Charles and the Infanta. In this respect, the ending of the play is all too clear: 'the foreign prince who came to pay court to the king's sister, must go home without her'. ${ }^{68}$ The issue of sufficient tact no longer seems to apply; if Charles really did see this play, he would certainly have understood its implications for his position.

This may well have been the intention of the Count of Olivares. Olivares has on more than one occasion been singled out as being

${ }^{62}$ Cruickshank, 'Calderón's Amor, honor y poder and the Prince of Wales', p. 78.

${ }^{63}$ Ibidem.

${ }^{64}$ Alonso Hernández, Spaanse letterkunde, p. 196.

${ }^{65}$ Cruickshank, 'Calderón's Amor, honor y poder and the Prince of Wales', p. 93.

${ }^{66}$ Ibidem, p. 75.

67 Ibidem, p. 78.

${ }^{68}$ Ibidem, p. 93. 
responsible for ruining the negotiations on purpose. ${ }^{69}$ Samson states that '[i]t was Olivares, working behind the scenes, who was largely responsible for deliberately wrecking the match'. ${ }^{70}$ In 1630 , Olivares himself boasted about his accomplishment in this respect. ${ }^{71}$ In 1622, Olivares, who had never been in favour of the marriage himself, was asked by Philip IV to find a way to get out of the marriage negotiations, because Philip III had his doubts about the match and asked his son to call it off just before he died..$^{72}$ When Charles suddenly appeared in Madrid in March 1623, Olivares could not just turn the royal guest down. He had to think of something that would put an end to the negotiations while maintaining the friendship with England. In the words of Redworth: '[...] what Olivares had to do over the long summer of 1623 was to find a way to make the Prince of Wales go home of his own accord'. ${ }^{73}$ Olivares decided to take subtle and diplomatic action. As Pursell puts it, Olivares's moves were 'counterproductive to the match, but they never involved breaching court protocol or sinking to the level of crude threats' ${ }^{74} \mathrm{He}$ simply stalled (and eventually frustrated) the negotiations by asking Rome to set strict conditions before granting the papal dispensation required to seal the marriage. One of the conditions was Charles's conversion to Catholicism-a highly unlikely event. ${ }^{75}$ The theatre plays may have functioned as another way to make Charles leave of his own accord-spelling out on stage what could not be said through official court diplomacy.

In the years after Charles's departure from Madrid, more plays were written looking back on the Spanish Match. According to Samson, '[i]n 1625, royal panegyrists still were explaining away the ruptured Spanish marriage. ${ }^{76}$ These later plays emphasize the religious objections

${ }^{69}$ Pursell, 'The End of the Spanish Match', pp. 700-01; Sánchez Cano, 'Entertainments in Madrid', p. 51.

${ }^{70}$ Samson, The Spanish Match, p. 2.

${ }^{71}$ Redworth, The Prince and the Infanta, p. 103.

72 Pursell, 'The End of the Spanish Match', p. 703; Redworth, The Prince and the Infanta, pp. 56, 67-69, 103; Sánchez Cano, 'Entertainments in Madrid', p. 63.

${ }_{73}$ Redworth, The Prince and the Infanta, p. 99. Also pp. 69 and 105.

${ }_{74}$ Pursell, 'The End of the Spanish Match', p. 713.

${ }^{75}$ Redworth, The Prince and the Infanta, pp. 5, 16-17, 90, 101-02, 105, 107-08; Robbins, 'The Spanish Literary Response to the Visit of Charles', p. 121; Pursell, 'The End of the Spanish Match', p. 710; Sánchez Cano, 'Entertainments in Madrid', p. 51.

${ }^{76}$ Samson, The Spanish Match, p. 5. 
to the marriage, and moreover they reveal the influence of Olivares. ${ }^{77}$ Particularly interesting in this respect is a play written by Francisco de Quevedo, Cómo ha de ser el privado (How the King's Counsellor Should Behave, 1629). According to Jeremy Robbins, this 'piece of theatrical propaganda' was written in favour of the Count of Olivares. ${ }^{78}$ Quevedo uses a character called Valisero, a clear anagram of Olivares, to voice (in retrospect) a negative opinion of the alliance between a Protestant and a Catholic. In this play, Charles is represented by the Protestant Prince of Denmark, who wants to marry the sister of the Catholic King Fernando of Naples-a marriage that (rather predictably) will not take place, because the Prince refuses to fulfil the Pope's conditions. ${ }^{79}$ These later plays indicate that the very topic of the Spanish Match is used as religious propaganda, even retrospectively. All in all we see that these plays served to convey a message that was contrary to the general tone of the negotiations, by advising against the marriage, mostly because of religious reasons. Moreover, some of the plays were commissioned by the Duke of Lerma and the Count of Olivares, who used these plays to convey their own pessimistic view of a possible marriage between an English prince and a Spanish princess.

As a matter of fact, things were not very different in England, although it took a while before the English court realized that theatre could be used to its advantage instead of considering it as a threat to national unity. To avoid upheaval, Elizabeth and James I had tried to put a stop to theatre plays on recent political and religious events. ${ }^{80}$ The plans for the Spanish Match in particular were considered a topic not to be discussed by the general public. As F.J. Levy puts it:

The nub of the matter was foreign policy and-though the King did not say so-most especially the Spanish marriage proposed for Prince Charles. It was this contentious business that generated "a greater opennesse, and liberties of discourse, even concerning matters of State, (which are no Theames, or subjects fit for vulgar persons, or common meetings)" than had in former times been permitted; and it was discussion of the marriage that the King wished to suppress. ${ }^{81}$

77 Cruickshank, 'Calderón's Amor, honor y poder and the Prince of Wales', pp. 79 and 95 .

${ }_{78}$ Robbins, 'The Spanish Literary Response to the Visit of Charles', pp. 117-19.

79 Ibidem, p. 121.

${ }^{80}$ Levy, 'Staging the News', p. 255.

${ }^{81}$ Ibidem, p. 252. 
Although there were plays celebrating victories of the English, it was forbidden to 'perform any modern histories nor speak of contemporary affairs' ${ }^{82}$ Yet it was the issue of the Palatinate that made the court realize it might be 'expedient to allow a wider scope to the dissemination of news' ${ }^{83}$ Levy connects the shift of power in the last years of James's reign to changes in the court's attitude towards news and drama. ${ }^{84}$ Things changed definitively after Charles had returned from Madrid:

By 1624, when Prince Charles and the duke of Buckingham were trying to drum up popular enthusiasm against Spain, the ban on discussing "causes of State, and secrets of Empire" made little sense, and efforts to reimpose it later proved futile. Instead, the "government" took pains to shape the news that was available, by censorship if necessary, by issuing its own version of events when possible. ${ }^{85}$

After Charles had returned to England a 'prolonged English anti-festival' was held as a response to 'the Spanish festival in Madrid which had welcomed Charles the year before' ${ }^{86}$ It involved a series of celebrations and performances expressing anti-Spanish sentiments, starting with the welcoming ceremonies on the Prince's return and ending ten months later with the performance of Thomas Middleton's A Game at Chess. Remarkably, this play is specifically criticizing the Jesuits. Middleton in fact was inspired by anti-Catholic pamphlets when he wrote his play. ${ }^{87}$ In Middleton's play, the stage is a chess board; the white pieces represent the English and the black pieces stand for the Spaniards who were involved in the marriage negotiations in Madrid. The Jesuits are exposed as being evil instruments in the hands of the Spanish government. In the first scene, the ghost of Ignatius of Loyola, the founder of the Jesuit order, appears together with his servant, called Error. The servant tells of a dream he had about a fight between the white pieces (the Spaniards) and the black pieces (the English) in a game of chess. The game (consisting of a variety of intrigues surrounding the Spanish Match) is then enacted by the other characters in the play, representing Charles, Philip, Gondomar, Olivares, Buckingham, a Jesuit bishop and

82 Ibidem, p. 259-60.

${ }^{83}$ Ibidem, p. 254.

84 Ibidem.

${ }^{85}$ Levy, 'Staging the News', p. 275.

${ }^{86}$ Darby, 'The Black Knight's Festival Book', p. 184.

87 Levy, 'Staging the News', p. 262. 
the other people involved. In the final scene, all of the black pieces are put one by one in a bag that represents hell. ${ }^{88}$ It appears that the plot of a battle between Catholics and Protestants, where the opponent is thrown into hell at the end, was popular not just among authors on the Catholic side. Various responses to the play have survived. An English member of the audience, Sir John Holles, described the play in a letter to a friend, pointing out the moral of the play as well as describing the stage. ${ }^{89}$ According to Holles, the play demonstrated 'the popular opinion, that the Jesuits mark is to bring all the Christian world under Rome for the spirituality, \& under Spayn for the temporal[i]ty..$^{90}$ Both the Spanish ambassador in London, Carlos Coloma, and the King of England reacted with indignation to this play. In August 1624, Coloma described Middleton's A Game at Chess in a letter to the Count of Olivares. ${ }^{91} \mathrm{He}$ considered the performance an insult to the Spanish. King James was 'furious' as well: 'He remembered well "there was a commaundment and restraint giuen against the representinge of anie modern Christian kings in those Stage-plays [... ]"'.92 Nevertheless, in order to perform the play for ten consecutive days, the author and actors must have enjoyed Court protection. This is why a number of scholars believe that A Game at Chess was probably part of a programme of anti-Spanish propaganda which was supported by the Prince of Wales. The person responsible may even have been the Duke of Buckingham himself. ${ }^{93}$ In that case, he would have used theatre in pretty much the same way as Olivares did, which was to stir public opinion in favour of their own point of view.

All in all, the play on the Battle of White Mountain as described in the Dutch manuscript account differs from the plays that were commissioned by the Spanish court. These Spanish plays choose a mythological or historical setting to discuss the problematic issues involved in the Match. In spite of these attempts to dissimulate a direct attack on the English, the true intention of these plays would have been all too clear for anyone who watched them. On the other hand, the play on the Battle of White Mountain does have a number of elements in

\footnotetext{
88 Ibidem, p. 261.

89 Braunmuller, "“To the Globe I rowed"'; Howard-Hill, 'The unique eye-witness report of Middleton's A Game at Chess'; Levy, 'Staging the News', p. 261.

${ }_{90}$ Braunmuller, "To the Globe I rowed"', p. 342; Howard-Hill, "The unique eyewitness report of Middleton's A Game at Chess'.

91 Darby, 'The Black Knight's Festival Book', p. 174.

92 Ibidem, pp. 261-62.

93 Ibidem, p. 262; Darby, 'The Black Knight's Festival Book', p. 177.
} 
common with the English response, A Game at Chess by Middleton. In both, we find a battle between Catholics and Protestants, with hell as the final destination of the opponent, and with a strong emphasis on the intentions of the Jesuits (albeit from a positive and from a negative viewpoint respectively). It is possible that the description of the play of the Battle of White Mountain fits in with anti-Spanish propaganda from the side of the English, rather than with the Spanish theatrical tradition. This assumption is reinforced by other evidence, which is a satirical English verse description of a Spanish play. This poem will be discussed in more detail in the next section, which deals with written accounts of theatre performances and their part in polemic discussions.

\section{WRITTEN ACCOUNTS OF THEATRE PERFORMANCES: PLAYING AT POLEMICS?}

Although eyewitness accounts of theatre performances are fairly rare, the account of the play of the Battle of White Mountain is not the only one to survive. Members of the audience were known to take notes during the performance, or to write an account of a play down from memory afterwards. ${ }^{94}$ Some of these reports were intended for private use only (in personal correspondence, diaries or manuscript miscellanies); others would serve a more professional purpose, such as the letters that were written following the performance of $A$ Game at Chess discussed in the previous section: Holles wrote a more private, informal account, while the ambassador's letter can be considered as an official report, serving international matters..$^{95}$ Other descriptions of theatrical performances would start circulating as pamphlets in manuscript and print. One might say that, while theatre plays were 'staging the news', as F.J. Levy calls it, these written and printed descriptions of performances were turning what happened onstage into news again. ${ }^{96}$

${ }^{44}$ Woudhuysen, Sir Philip Sidney and the Circulation of Manuscripts, pp. 141 and 149-50; Chartier, 'Copied onely by the eare'; Bouza, Corre manuscrito, pp. 40-43. There is a Dutch rhetorician's play featuring 'spies' taking notes during the performance of the play (Moser, De strijd voor rhetorica, p. 53).

${ }_{95}$ Levy, 'Staging the News', p. 263; Woudhuysen, Sir Philip Sidney and the Circulation of Manuscripts, p. 166.

${ }_{96}$ Levy points to the close link between 'news, newspapers and topical drama' (Levy, 'Staging the News', p. 254) and calls the play Sir John Van Olden Barnavelt a 'news play' and a 'staged newsbook' (Levy, 'Staging the News', pp. 257 and 259). 
Or rather, what is suggested as having happened onstage, for these pamphlets do not necessarily refer to real performances. Some descriptions of dramatic performances seem to have served as a vehicle to express a view on actual matters-whether or not the play was actually performed. I will illustrate this by discussing three examples, the first of which is related to the Spanish Match.

There is an English verse libel in manuscript entitled 'On a Shew presented before Prince Charles in the Spanish Courte'. ${ }^{97}$ As the title indicates, the poem describes a play that was performed on the same occasion as the play on the Battle of White Mountain: the visit of the Prince of Wales in 1623. The poem begins:

The Prince of Wales with all his royall traine

Was entertained in the Courte of Spaine:

The Catholikes theire respects disclose

Delighting him with Feasts, \& Maskes, \& Shewes.

The poem describes how the Spaniards were entertaining the Prince of Wales while the Pope was lying ill. When he died, the Spanish planned to honour him before the Prince of Wales, with 'antike shewes and tricks'. One play in particular is described, about a fight between Catholics and Protestants. This play is performed on a two-tiered stage, just like the play on the Battle of White Mountain:

Within the Stage heav'n placed is on high

Opposd to which hells dreadfull gulfe doth lie.

The Catholics who die in the fight, are transported straight into heaven, while the Protestants ('Poore Puritanes') are thrown in hell by thousands of devils. When the Pope himself dies, he is carried up to 'heaven' as well, by a rope:

Amongst the rest the Holy Father dies,

As soon he must be mounted to the skies.

And that they may the more advance the Pope

They wind him into heaven with a Rope

But just when he reaches the upper stage, the rope breaks and the Pope falls down, straight into the lower compartment of the stage:

${ }^{97}$ Early Stuart Libels, Nv14 (http://www.earlystuartlibels.net/htdocs/spanish_match_ section/Nv14.html). Bellany and McRae edited the text according to Bodleian MS Eng. Poet. e.97, pp. 167-68; another manuscript copy has been preserved in BL MS Sloane 542, fol. 37 r. 
All watch his Entrance; But I feare to tell!

The Rope breaks! The Pope falls into hell!

Thus, the head of the Catholic Church ends up in hell, along with the Protestants. The author of the poem mockingly comforts the Catholics by assuring them that the Pope has merely entered purgatory and will surely reach heaven in the end. He then makes fun of the breaking of the rope, commenting that the other actors should have carried the Pope on their backs. He suggests that the accident was due to the heavy drinking that the actors had been doing. The weight of the Pope is explained first by his many virtues, then by his abundant lifestyle, then by the attributes he holds and finally by his guilty conscience:

Where lay the fault? what did the man deceave thee?

Or did hee not foresee the Pope was heavie?

Methinks thou shouldst have considred that

His greate revenues needs must make him fatt.

Besides perhaps he carried up about him

Copes, Miters, Crosses, pixes, roodes without him.

Doubtles within there was wondrous weight;

His Heart \& Conscience was not very light.

And drawing upward such a heavie Pope

How could it be but he must breake the Rope?

The author concludes that the rope just had to break, carrying such a heavy Pope, and that thanks to a weak rope, the Pope has ended up where he belongs:

Since this it stands that heaven did deceave him,

And that small Rope of such great Joyes bereave him;

Yett Hell was ready alwaies to receave him,

There was he found att first \& there I leave him.

According to the modern editors of the verse libel, the description of the play and the falling of the Pope might be fictional and not refer to a real performance. They write:

This lumbering exercise in anti-Catholic wit does not seem to have been occasioned by any actual mishap at a show staged for Prince Charles in Madrid. Rather, the poem attempts to make some mild polemical capital out of the death of Pope Gregory XV in the summer of $1623 .^{98}$

\footnotetext{
${ }^{98}$ Bellany and McRae in their introduction to Early Stuart Libels, Nv14 (http:// www.earlystuartlibels.net/htdocs/spanish_match_section/Nv14.html).
} 
This would mean that the subject matter on its own would serve as an instrument in opinion forming, regardless of a real performance. This is not the only occasion where a description of a theatre performance seems to have been used to stir up a polemic. There are two other examples that I would like to discuss: a printed pamphlet in Dutch describing a play that was performed at the Spanish Court in 1588, and a series of poems on a performance by the Antwerp rhetoricians in 1631.

The 1588 pamphlet was printed in Utrecht on the basis of a London 'Copy', as the title page states. The title translates as follows: 'A true declaration of a miraculous farce that was performed at the Court of the King of Spain and is full of events, written to serve as a warning to all, not to suffer the same force and slavery like you will find explained here' ${ }^{99}$ Like the manuscript account of the play on the Battle of White Mountain, this too is a description in Dutch of a play that was performed at the Spanish Court, be it a few decades earlier. The author starts describing the performance without any further ado. On the stage, there is a pedlar, together with three sovereigns: the king of Spain, the king of France, and the king of Sweden. They ask the pedlar what he has got on offer, and he replies that he is selling Holland, Zeeland and Friesland. The Spanish king refuses to buy what is already his. The French king is not interested in the merchandise. The Swedish king does fancy the lands, but he is afraid they might already belong to someone else. The pedlar assures him this is not the case. They used to belong to the king of Spain, he says, but they no longer accept him as their sovereign. When the pedlar gives the reasons for their renouncing the Spanish king, describing the situation in the Low Countries and giving a favourable image of the Prince of Orange, the king of France asks who he might be. The pedlar says his name is well known: he is 'the state of the nation without council'. The French king immediately drags the pedlar to the king of Spain, in order to make him account for himself. The pedlar must hand over his merchandise, and all actors briefly retreat behind a curtain. When the pedlar appears again, he wears a velvet cloak and a beautiful hat, and he holds a paper saying 'This is the state of the nation without council'. The others make him kneel on a cushion, and the pedlar is beheaded with a sword (the author mentions the use of cow's blood in

\footnotetext{
${ }_{99}$ Een warachtighe verclaringhe van een wonderlijck Batement-spel [...].
} 
the process). At the same time, other martyrs are shown to be hung or burnt on the stage, while Holland, Zeeland and Friesland are pillaged by soldiers and finally ripped apart and thrown to the floor. There is no doubt about the objective of this pamphlet. The title page clearly states that it is meant as a warning to prevent people from being forced into such slavery as is described in the text. The description of the play is followed by a short poem about Babylon, saying that it should be shunned because of its wickedness. Moreover, there is a separate 'conclusion' at the end of the pamphlet, saying that this play shows how the King of Spain is planning to maltreat the Low Countries, and expressing the hope that Elizabeth, Queen of England, will fight the King of Spain with the help of God. The detailed description of the performance and the props make it seem plausible that this description is based on a real performance, but as with the play on the Battle of White Mountain, this is the only source referring to the play. The original text has not been preserved. It is interesting that the 'copy' of this pamphlet originated in London. Once more, this indicates traffic of pamphlets between England and the Netherlands. ${ }^{100}$

The third and final example of a polemic description of a play involves the Antwerp rhetoricians. In 1631 the Dutch poet Jan van der Veen published a poem criticizing a play that allegedly was performed by the rhetoricians in Antwerp. ${ }^{101}$ According to the poem, the actors brought an image or statue of Frederick Henry, Prince of Orange, onto the stage, representing him 'slain as a dead man'. After some contemplation of the figure, a doctor entered the scene, and started to dissect the body in search for the heart of the deceased. In the end, the heart was located behind his heel, which was considered as a sign of his lack of courage. Not only is the text of this play just as irretrievable as the text of the play on the Battle of White Mountain, but also the Antwerp rhetoricians strongly denied ever having performed such a play. Several of them wrote poems in reply to Van der Veen's accusations, declaring that they would never insult a prince in this manner. They call Van der Veen a liar, who has invented the play all by himself, stealing subject matter from other sources. Van der Veen in turn wrote another poem, saying he is no liar, but that he merely put into words a play that was performed in secret, not publicly. He refers to a

${ }^{100}$ Levy, 'Staging the News', pp. 266-67.

101 Sabbe, Brabant in 't verweer, pp. 173-83. 
similar play that was performed in Cologne, dealing with the demise of Frederick of Bohemia and his wife, depicting them as beggars. ${ }^{102}$ This was just as real and as demeaning a play as the Antwerp one, according to Van der Veen. Again, the Antwerp rhetoricians deny having ever performed the play, and once more, Van der Veen writes another poem accusing them. It remains unclear whether the performance by the Antwerp rhetoricians took place or not. But even without answering this question, it has been suggested that Van der Veen's intention to write the original poem might have been to incriminate the rhetoricians from the Catholic south and to stir public opinion in favour of Calvinism. ${ }^{103}$

The three descriptions of performances that have been discussed in this section all voice a clear and critical view on the performance that is described, which makes it plausible that they were written with the intention of influencing public opinion. What is more, all three of them criticize Catholics from a Protestant point of view. They all describe performances of a play that deals with current affairs. Another thing they have in common is that they present a form of ekphrasis: they very vividly express in words what the audience would have seen on the stage, spiced up with particular details: the dissection of the body of Frederick Henry in the play described by Jan van der Veen, the cow's blood in the play on the pedlar selling the Low Countries, the breaking of the rope in the play on the Pope. Even if the performances that they describe were completely made up, ample effort has been made to render the accounts convincingly realistic.

It seems plausible that the description of the play on the Battle of White Mountain had a status similar to the three descriptions discussed in this section. It only differs from the other three in that it does not give an explicit opinion or view on the subject matter of the play. Since the account remained unfinished, we will never know if the author or scribe intended to include an explanatory conclusion, like the one in the Dutch pamphlet of 1588. Nevertheless, what the account of the play on the Battle of White Mountain has in common with the other descriptions discussed here, is the fact that it represents a play on current affairs and the vividness and detail of the description. In addition to that, three out of the four performances discussed were

\footnotetext{
${ }^{102}$ Ibidem, p. 180.

103 Ibidem.
} 
situated at the Spanish Court. Moreover, there are remarkable similarities between the play on the Battle of White Mountain as described in the Dutch manuscript prose account, and the play on the death of the Pope as described in the English manuscript verse libel. Both texts deal with a performance that took place before Prince Charles during his visit to Madrid. Both describe the same type of play on similar subject matter, using an identical stage setting and theatrical effects: a battle between Catholics and Protestants on a two-tiered stage representing heaven and hell. In both plays, hell is the final destination of the Protestants and in both descriptions the higher stage is reached with a rope. These similarities may be more than a mere coincidence. They either suggest that such plays were indeed performed at the Spanish Court, or they suggest that this kind of imagery was used by antiSpanish polemic authors, who would be 'staging' similar performances to make the Spanish look bad.

\section{Conclusion}

This article set out to investigate the status of manuscripts and performances in the interplay of literature and public opinion. It focussed on one source in particular, which was a manuscript description of a performance that allegedly took place in Madrid in 1623 during the visit of the Prince of Wales. It turned out to be impossible to give a conclusive answer when it comes to the reliability of the Dutch account of the Jesuit play on the Battle of White Mountain, since the performance is not mentioned in any pamphlets, relaciones or newsletters on the Spanish Match. Should it be a true account of a real performance, then it would provide a completely new view of the entertainment offered to Prince Charles. On the other hand, if it should be considered as a fictional representation of a performance (which seems more likely), this text points to new directions for further research, taking into account a new genre of fictional performances written for polemic purposes and distributed in pamphlets in manuscript and print.

I started out by taking the first option into consideration. The overall lack of evidence of the play to corroborate the account itself-no references, no written or printed versions-fuels the suspicion that the play was never a part of the entertainment presented to the Prince of Wales. It is quite unlikely that Jesuits would have performed a play on the Battle of White Mountain featuring a character like Xaltrax on a 
two-levelled stage in front of Prince Charles and the Spanish Infanta in Madrid in 1623. The harsh tone and message of the play as it is described in the manuscript account represent a drastic departure from the general description of the courteous entertainment offered to the English prince in the printed pamphlets, which intended to represent first and foremost the friendly relations between the King of Spain and the Prince of Wales. The play is also very different from the Spanish plays that were written on the Spanish Match, which voice negative views on the marriage by representing other fatal marriage plans. At the same time, however, the cruel rejection of the Elector Palatinate on stage does seem to indicate a level of provocation that is part of other Catholic literature written for propaganda reasons. The account contains a number of elements that suggest that the play fits in with the characteristics of the new type of comedia that was part of Spain's campaign to boost the Spanish self-esteem: the onstage battle, the representation of recent military victories, the negative depiction of the enemy and the exhortation to defend the Catholic religion. But this hostile stance is not exclusive to Spanish theatre. There are also a number of similarities between the play as described in the manuscript account and the English play A Game at Chess that Middleton wrote as part of an anti-Spanish campaign started by Charles when he returned from Madrid: the battle between Catholics and Protestants, hell as the final destination of the enemy, and the message that the Jesuits wish to eradicate all who do not adhere to the Catholic church. This might indicate that this text does not necessarily fit in with Spanish literary tradition, but rather with a polemic tradition on the English side, drawing on the same type of plot and imagery.

This leads to the second option, considering the text as a fictional account, written for polemic reasons. The document may be seen as a manuscript pamphlet (whether it be an unfinished copy of an existing text, or a draft version of a new text), in which a vivid description of a drama experience is used to voice an opinion on a current affair'staging' a performance for polemic ends, so to speak. There have been other pamphlets and verse libels that use the same technique, three of which were discussed in this article. All were written from a Protestant point of view. One of the three theatre descriptions discussed, representing the death and ascension of the Pope, was related to the Spanish Match as well. It shared certain characteristics with the description of the play on the Battle of White Mountain: both repre- 
sent a battle between Protestants and Catholics on the two-tiered stage with a rope leading to heaven and a trapdoor towards hell. Again, this kind of imagery seems to be representative of an English anti-Catholic polemic discourse.

All of the above, however, is just a matter of speculation. If little to nothing can be proven about the origins, function and impact of the manuscript account nor of the presumed performance, what is the use of this document in terms of investigating the relation between literature and public opinion? It invites us not to trust the eyewitness. It forces us to use circumstantial evidence provided by historical as well as literary sources. It urges us to think beyond print and take into account manuscript and performance as well, on a more substantial basis. Further research is needed to be able to compare this source to other descriptions of performances. By following the traces of the formation of opinion in sources like these, we may in the end achieve a fuller and better understanding of the interplay between literature and public opinion. If anything, this flimsy, mottled piece of paper has demonstrated just how rich, complex and multilayered this relation can be.

\section{Websites}

- British library: Renaissance festival books (http://www.bl.uk/treasures/festivalbooks/homepage.html)

- DAG: Digitale Atlas Geschiedenis (http://www.digitaleatlasgeschiedenis.nl/)

- 'Early Stuart Libels: An Edition of Poetry from Manuscript Sources.' Ed. Alastair Bellany and Andrew McRae. Early Modern Literary Studies Text Series I (2005). (http://purl.oclc.org/emls/texts/libels/)

- TEMPO: The Early Modern Pamphlets Online (http://tempo.idcpublishers.info/)

- Théâtrales, ed. André G. Bourassa (http://www.theatrales.uqam.ca/chronologie/madrid.html)

\section{Rariora}

- A continuation of a former relation concerning the entertainment given to the Prince His Highnesse by the King of Spaine in his Court at Madrid. London. Printed by John Haviland for William Barret. 1623. [Early English Books Online; http://eebo.chadwyck.com] 
- Een batement spel dat in Spaengien binnen madril gespeelt is.

[Regionaal Archief Leiden ms. 72422 portefeuille folio]

- Een waerachtich verhael ende iovrnael van de maniere van de aenkomste des Hoogen ende machtigen princes Caerle, Prince van Groot Britannien, inde Stadt van Madril, ende van 't magnifijck onthael by den koninck van Spanien aldaer te Hove aengedaen. In 'sGravenhaghe. By Aert Meuris Boeckverkooper inder Papestraet, in den Bybel. Anno 1623.

[Koninklijke Bibliotheek Den Haag pflt 3409]

- Een warachtighe verclaringhe van een wonderlijck Batement-spel, dat ghespeelt is int Hof vanden Coninc van Spaengien, ende is seer avontuerlick om lesen, tsamen gestelt tot een waerschouwinghe voor alle Menschen, om niet te comen tot sulc-dwanck ende slavernije, ghelijck U.L. hier verclaert sult vinden. Ghedruckt tot Utrecht na de Copije van Londen. An. 1588.

[Universiteitsbibliotheek Leiden THYSPF 751] 


\section{Appendix A: Een bATEMENT SPEL DAT IN SPANGIEN BINNEN MADRIL GESPEELT IS ${ }^{104}$}

\section{[fol. 1 recto]}

Tot verwonderinge van vele menschen sal ul, verklaert worden van een, mirakuluesse klucht, ofte coomedie welcke gespeelt is in spangien '<tot>' madril, alwaer de coninck tegenwoordick syn hoff is houdende oock soo syn veele kenbaer dat den prins van wallees soone vanden coninck van Engelant Jnt Jaer 1624 als daer binnen madril gearriveert is geweest ende aldaer gecoomen was soomen seyden om te trouwen den cooninck van spangien suster, hier door worden in spangien veel verscheyde spelle ende coomedien aengerecht om den prins van wales te vermaecken ende synen geest te verhuegen soo ist gebuert dat die jesuyten gecompooneert hadden een coomedij spel van den roomschen keyser ferdunandus ende van frederikus cooninck van bohemen dus waren daer gemaeckt groet hooge stellasie daer alle eedelen van heeren en vrouwen op saten om het spel te beschouwen oock was daer [-oock] een herelycken stoel bereyt daer den prins van walles met coninx suster ende den cooninck ende cooninginne met grooter heerlyckheyt in saeten soo was daer beneeve int midde vande stalasie gemaeckt een groote toonel daermen die coomedie op speelde als nu de personagie al gereet ware om te speelen soo quam daer eerst een op de toneel in een cooninclijcke kleet hy quam met veel kryx volck alles inde wapenen dit was quansuys de cooninck van boheeme die te velde quam om tegen den roomschen keyser te stryden ende als deese met eene groote macht van soldaten op de tooneel stont soo quam daer een andere party haer oversten hadden op synnen hooft een kroon als een roomschen keyser dus quamense tegen malcanderen in batalye den keyser moste eerst een weynich wycken ende hadt den slach bycans verlooren do[-o]en quam byden Ceyser een met witte cleere dat was $\left[-^{*} .{ }^{\star}\right]$ '<xaltrax $>$ ' eenen geest die uijt den heemel quam tot den keyser gesonden was om hem te troosten en te hulpen de oude Cotolycken leeren te beschermen en voorte staen doe dese geest was bijdden Keijser altoos inden strydt ende tot drie ofte vier batalie hadt die keyser de over hant int leste geschieden aen weeder syden een groote slach dat

\footnotetext{
104 The original manuscript is in the Gemeentearchief Leiden (The Netherlands), ms. 72422 portefeuille folio.
} 
was soo veel te seggen die slach van pragh dat stryden was seer genuchgelyck om te si[-j]en want sy schooten al met loos kruijt:.

[fol. 1 verso]

Tegen malcanderen, ende schermutseerden wel een half uijre eyndelyck wast gemaeckt dat den kooninck van boohemen het velt rumen mosten ende dat door de witte geest die den keyser te hulpe gecoomen was sonder dat den keyser het velt selfs hadt moeten ruymen als dese batalye en schermutsingen alles gedaen was werden den keyser groote eer aen gedaen maer hier na geschieden een wonderlyck klucht want daer waren twee toonelen [-onder] boven malkanderen onder de leste tooneel werden veel vier gestoockt van hout swavel en peck dat was soo veel te seggen als die hel die waren romtomme met plancken toegespickert datmen daer niet onder duer mochten [-loopen] loopen ende int midde van $\mathrm{d}^{\prime}<\mathrm{i}>$ 'e onderste tooneel was eene groote luyck val gemaeckt dat werden open gedaen daer quam eene groote vlam vier uijt dat was soo veel als die hel ende daer werden de kooninck van bohemen in geworpen van gemaeckte duyvels omme dat hy tege de oude roomsch katolycke leere hadt op gestaen ende omme ende omme dat hy met de ketters te velden gecoomen was doen quam de geest met witte kleeren die den keyser geholpen hadden twelcken een Jesuwyt was die deden op het tooneel een reeden en sprack met luyder stemmen alsoo sullense '<alle>' inde afgront der hellen geworpen worden die niet oprecht en geloove aen onse oude roomeynsche leere booven het tooneel daer de geest op stont was noch een tooneel [-gemaeckt] dat was op vier masten gemaec soo hoogh als eenige huysen dat binnen madril wesen mach daer en kondemen niet op coomen oftemen mosten daer met een tou op $s$

\section{A play that was Performed in Spain IN Madrid ${ }^{105}$}

You will hear a story that will astonish many people, of a miraculous farce or comedy that was performed in Spain in Madrid, where the king resides nowadays. Many people know well enough that the Prince of Wales, son of the King of England had come to Madrid in

105 Translation my own, NM. 
the year 1624 with the intention of-as was told-marrying the sister of the king of Spain. On this occasion many plays and comedies were performed in Spain for the entertainment and joy of the Prince of Wales.

It so happened that the Jesuits had written a comedy on the Roman Emperor Ferdinand and Frederick, the King of Bohemia. A large and high gallery was made where all noble men and women were seated to watch the play. There was also a royal seat where the Prince of Wales together with the sister of the King and the King and Queen were seated in beautiful attire. Furthermore, in the middle of the gallery, a large stage was made where the play was performed.

When all actors were ready to play, the first one to enter the stage was dressed in a royal outfit, accompanied by many armed soldiers. He represented the King of Bohemia, who was preparing to fight the Roman Emperor. When he stood onstage with a large number of soldiers, another group entered the stage. On his head, the leader wore a crown like a Roman emperor. Thus they engaged in a fight. At first, the emperor had to give in a little and he nearly lost the battle. Then a person dressed in white joined the emperor; this was Xaltrax, a spirit from heaven. He was sent to the emperor in order to comfort him and help him protect and defend the old Catholic doctrine. When this spirit was with the emperor, he fought constantly and after three or four battles the emperor had the upper hand. Finally a heavy battle was fought on both sides, namely the Battle of Prague. The fighting offered a very entertaining spectacle, because they all shot with blank cartridges and fought for about half an hour. At last they succeeded in forcing the King of Bohemia to leave the field, thanks to the spirit that had come to help the emperor, without the emperor having to give in. When this battle and all the fighting had ended, the emperor was honoured abundantly.

But after this a miraculous farce took place. You need to know that there were two stages on top of each other. Under the lowest stage a large fire was made of wood, sulphur and pitch. This was supposed to represent hell. All around, this stage was nailed up with wooden boards to prevent people from walking underneath. In the middle of the lower stage a large trapdoor was made. It was opened and a large flame came out of it; this was hell. The King of Bohemia was thrown in there by pretend devils for having risen up against the old RomanCatholic doctrine and for having joined forces with the heretics. Then 
the spirit in white, who had been helping the emperor, made his entrance. He was a Jesuit who delivered a monologue on stage, saying in a loud voice: 'In this manner all who do not sincerely believe in our old Roman doctrine will be thrown into the precipice of hell'.

Above the stage where the spirit stood was another stage, made on four poles as high as some houses in Madrid. No one could enter there but by taking a rope and $\mathrm{j}$ [umping]. 


\title{
'THE CRY OF THE ROYAL BLOOD': REVENGE TRAGEDY AND THE STUART CAUSE IN THE DUTCH REPUBLIC, 1649-1660
}

\author{
Helmer Helmers
}

On 9 February 1649 Charles I was executed before Whitehall Palace in London. The regicide and the subsequent abolishment of the monarchy in England marked the beginning of an intense propaganda campaign by royalist exiles on the continent, the like of which Europe had not often seen before. This campaign was targeted at two distinct markets. In the first place, publications in English were meant to keep royalist sentiments alive at home. ${ }^{1}$ More importantly, royalists sought to acquire foreign support for an invasion that would restore Charles II to the throne, through publications in Latin and the European vernaculars. The Dutch Republic was pivotal in the royalist efforts. Not only did it serve as the bookshop for both markets, where the bulk of royalist publications were printed and dispatched, ${ }^{2}$ it was also the single most important target nation for their propaganda. ${ }^{3}$

Officially, the Dutch had maintained a policy of neutrality in the English conflict between King and Parliament ever since it erupted in 1642. Yet behind the neutral façade, the political elite of the Republic

${ }^{1}$ In recent decades, royalist literature and propaganda have received ample attention. Consider, for example: Anselment, Loyalist Resolve; Potter, Secret Rites and Secret Writing; Maguire, Regicide and Restoration; Zwicker, Lines of Authority; Smith, Literature and Revolution in England; Wilcher, The Writing of Royalism. See also: Randall, Winter Fruit. Although Dutch pamphlets are occasionally discussed in some of these works, the effect of royalist publications on public opinion on the continent, on which the royalist cause depended so much, has hitherto been largely neglected. Notable exceptions are R. Priebsch, 'German pamphlets in prose and verse on the trial and death of Charles I', and Berghaus, Die Aufnahme der englischen Revolution in Deutschland. Paul Sellin's case study of the prefatory material to Salmasius's translated Defensio Regia does recognize the importance of Dutch material for the royalist cause and has been an important point of departure for this study. See Sellin, 'Royalist Propaganda and the Dutch Poets on the Execution of Charles I'.

${ }^{2}$ Hellinga, Duke, Harskamp and Hermans, The Bookshop of the World.

${ }^{3}$ For an account of the royalist propaganda efforts in Scandinavia, see Murdoch, 'The Search for Northern Allies'. 
had been utterly divided about the British troubles. Whereas the States of Holland and Zeeland had repeatedly shown their willingness to accommodate Parliament, the King could count on the warm-hearted support of the House of Orange, especially after William II succeeded his father Frederick Henry as stadtholder. ${ }^{4}$ William made restoring his brother-in-law Charles II to the throne of England one of the central aims of his foreign policy. ${ }^{5}$ If Orange could overcome Holland's resistance and gain power over the United Provinces, so both Commonwealth leaders in England and the English exiles on the continent believed, war against the English Republic would be a matter of time. With France being occupied by the domestic turmoil of the Fronde and the Franco-Spanish War (1635-1659) and Mazarin being deaf to royalist pleas, the most realistic scenario for a successful royalist invasion involved the mobilization of the resources of the United Provinces. The Dutch had to be convinced that they should assist the exiled son to vindicate his father, and Holland was the key. ${ }^{6}$

One of the major works designed to gain continental support for the royalist cause was Claudius Salmasius's Defensio Regia (Defence of Kingship, November 1649).7 Allegedly paid '100 jacobuses' by Charles II, ${ }^{8}$ the Huguenot Salmasius (1588-1653), professor at the Leiden University, became the front man of the continental royalist propaganda campaign after the execution. In his book, which rapidly gained fame, he argued not only against the regicide, but also in favour of the right of the Prince of Wales to succeed his father as king of

${ }^{4}$ Cf. Geyl, Orange and Stuart, passim. Geyl's provocative, rather anachronistic argument that the Princes of Orange put their own dynastic interest in the Stuart cause before the national interest has been thoroughly revised by Simon Groenveld, who has convincingly argued that Frederick Henry was not the uncritical Stuart supporter Geyl portrayed him to be. See Groenveld, Verlopend Getij, passim. During the few years William II was in office, however, the Stuart interest was prominent on the agenda.

Kernkamp, Prins Willem II, pp. 68-78.

${ }^{6}$ As argued by Sellin, 'Royalist Propaganda', passim.

7 The many editions of the Defensio are listed in Madan, 'A Revised Bibliography'.

8 At least this is Milton's claim in the Defensio pro populo anglicano (1651), which was translated into Dutch as Verdedigingh des gemeene volcks van Engelandt tegens Claudius sonder naem, alias Salmasius Konincklijcke Verdedigingh (Amsterdam: J. Janssonius [Madan], 1651) and in Milton studies is commonly referred to as his First Defence. Although Salmasius later denied the allegation (he wrote that the line 'sumptibus regiis' had only been added to the title page to add authority to his text and to prevent problems with the censor) there are no good reasons to disbelieve Milton and the claim on the title page. 
England, Scotland and Ireland. According to the Defensio, European kings and princes should unite against the English 'parricides' in order to secure Charles II's rightful inheritance. This was in their own interest, because rather than an attack on one dynasty, the execution of the king had been an assault upon the institution of monarchy, rightful government and indeed upon God himself. If no retaliation were to follow, continental governments would run the risk of incurring the same fate as the English king. Although this argument would ultimately fail to convince European governments, who adopted an attitude of 'wait and see' with regard to developments in Britain, ${ }^{9}$ it did provoke fierce reactions throughout Europe. In Holland in particular, where the English conflict was so intimately interwoven with domestic religious and political issues, Salmasius's appeal reverberated loudly in the public sphere.

After forbidding the printing, importing and selling of all texts 'damaging and disrespectful to either the king or the parliament of England' in November $1649,{ }^{10}$ the States of Holland banned the Defensio in whatever size or language' in January. ${ }^{11}$ Despite the ban a Dutch translation of Salmasius's book was printed in Leiden by Johan van Dalen in March 1650, albeit under a false imprint. Later editions appeared in Rotterdam, Utrecht and Antwerp. ${ }^{12}$ In his article on the later Naeranus edition of the same translation, Paul Sellin has drawn attention to

9 Bonney, 'The European Reaction to the Trial and Execution of Charles I'. According to Bonney, pp. 270-71, the great European powers 'operated on the principle of state interest', which dictated that a weak and divided England was more profitable than an uncertain invasion aiming to restore Charles II to the throne.

${ }^{10}$ Grosheide, Cromwell naar het oordeel van zijn Nederlandse tijdgenoten, p. 26.

11 Translated from the original Dutch: 'in wat formaet ofte tale het soude mogen wesen'. See Knuttel, Verboden Boeken, p. 34 nr. 113.

${ }_{12}$ See Madan, 'A Revised Bibliography'. There are four known Dutch editions of the Defensio Regia (Dutch: Koninklijkke verdediging, voor Kaarel den I, etc.), all published in 1650. Three appeared in the United Provinces: the first was printed in Leiden in March under the false imprint of Antwerp (Van Dalen), which was followed by a Rotterdam edition in June ('Iohan van Rene' $=$ Johan van Neer $=$ Johannes Naeranus). Van Dalen and Naeranus used the same translation. The only difference between their texts is the latter part, which is abbreviated in the earlier Van Dalen edition. An independent text appeared in Utrecht (unknown printer). According to the Short Title Catalogue Vlaanderen, a certain Arend van der Toppen's translation was printed in Antwerp in 1650. I have not been able to compare the text of this edition-now in the Erfgoedbibliotheek Hendrik Conscience in Antwerp - to the other ones, but it is likely that it was independently translated and published for the Southern Netherlands. This would be confirmed by a statement made by Salmasius himself, who in his Ad Johannem Miltonum responsio claimed that three Dutch translations circulated 'diversis auctoribus' (See Grosheide, Cromwell, p. 21). 
the prefatory poems that were added to the main text. Leading Dutch poets, including Vondel, Vos, De Decker, Oudaen and Brandt, here united with the Huguenot Stuart propagandist Salmasius in order 'to secure the soul of Holland' for the royalist cause. ${ }^{13}$ The Dutch editions of the Defensio are an interesting case for at least two reasons. First, notwithstanding the repeated ban, the editions proclaimed their status as royal propaganda with remarkable openness. The title pages of their translations boasted the royal coat of arms and, like the original, explicitly stated that the book was printed 'at the king's expense' ('op 's konings kosten'). In all likelihood the entire enterprise of publishing the Latin and vernacular editions was, in Sellin's words, 'an extensive, subsidized undertaking', which, apart from the Leiden professor, involved several Dutch printers, translators and poets. ${ }^{14}$ In the second place, the prefatory poems in the vernacular editions signal an alliance between the royalist propagandists in the United Provinces and several members of the literary elite of Holland. This essay is an attempt to come to an understanding of the significance of that alliance, from the political as well as from the literary perspective.

The regicide and the royalist propaganda effort in the United Provinces constitute an essential background for a correct understanding of the political impact of a sizeable body of literature in the 1650s. ${ }^{15}$ Both before and after the publication of the Defensio, the Stuart cause was embraced in hundreds of poems, plays and songs, written in the vernacular by authors ranging from the Orangist freethinker Jan Zoet to his Amsterdam Catholic enemy Jan Vos, ${ }^{16}$ and from the apothecary Jan Six van Chandelier to the influential Dordrecht diplomat and magistrate Cornelis van Beveren. ${ }^{17}$ Surely the variety of this group-

${ }_{13}$ Sellin, 'Royalist Propaganda', passim and esp. p. 259.

14 Ibidem, p. 261.

${ }^{15}$ For earlier accounts of Dutch reactions to the regicide, see Grosheide, Cromwel naar het oordeel van zijn Nederlandse tijdgenoten, and Scherpbier, Milton in Holland, pp. 41-56.

${ }_{16}$ Zoet wrote at least eight poems related to the regicide in 1649-1651, among which Het tooneel der Engelsze elenden (1650, see below) and Vorstelikke-Lijk-Staasy, gepast op de Dood van Carel Suart, Koning van Groot Britanje (1649). Among many epigrams, Jan Vos' main contribution to the torrent of poetic comments on the regicide before the outbreaks of the Anglo-Dutch war was his Britanje aan Europe (1649).

${ }^{17}$ Of the many poems in which Jan Six van Chandelier reflected on the regicide, his Rariteiten te koop (1649), which focuses on the magical qualities of the king's blood, is arguably the most interesting. See Jacobs, J. Six van Chandelier, 1, p. 272. Cornelis van Beveren was so attached to the English royal family that he gave his son the name of 
socially, religiously as well as politically-raises questions about the motivations behind the Dutch support for the Stuarts.

To argue the connection between Stuart propaganda and this varied group of Dutch poets does not mean to imply that they were, like Salmasius, involved in an orchestrated campaign. Only some of the published texts can be linked to the English court in exile, and even then only tentatively. Reyer Anslo's Kroonrecht door gewelt verkracht (Divine Right Violently Ravished, 1649), for example, was printed in plano with the royal coat of arms figuring prominently above the text. ${ }^{18}$ Although this does suggest some official involvement, the suggestion may well be a deliberate effect independently created by the author or the printer. In the absence of any evidence to the contrary, we must assume that these poets for the most part acted independently from the Stuart court. Nor is it likely that the House of Orange had a hand in the publication of a significant part of the pro-Stuart poetry. As we shall see, the Orange court was probably connected to the publication of two pro-Stuart engravings (both of which involved the collaboration of Jan Zoet) in or about 1650. It is unlikely, however, that poets like Oudaen or Vondel would have acted under the sway of the Orange court in this particular period, as they were (and still are) well-known for their dislike of William II.

If direct political interference cannot explain the torrent of proStuart poetry, but made only a (numerically) minor contribution to it, how then can the appeal of the Stuart cause to such a broad range of independent authors be explained? Part of the answer is the multifaceted nature of that cause, its ability to keep diverse and at times conflicting ideologies together under the banner of royalism. ${ }^{19}$ Dutch

Karel after he had visited England in 1636. He is the C.V.B. who published four poems in a 1649 pamphlet in the Universiteitsbibliotheek Leiden (Thyspfl., 5370).

${ }^{18}$ Knuttel, 6341-42, Reyer Anslo, Karel Stuart, Koningh van Groot Brittanje, etc. of Kroonrecht door Gewelt verkracht: Formidolosum regibus exemplum. Plebs furibunda ruit (1649).

19 Historians of the English Civil Wars and Interregnum have come to realize that royalism was never a monolithic ideology, nor simply to be divided in the convenient dichotomy of 'absolutists' and 'constitutionalists'. Instead the term covered a broad range of people who rationalized their support for the king in such diverse ways as to cause frequent discord and conflict (See e.g. McElligott and Smith, Royalists and Royalism, pp. 1-15 and 66-88). In view of the fact that after, roughly, the battle of Naseby, English royalism was increasingly a continental movement, with its success depending on continental support, it is not misplaced to expand the term as to include continental supporters of the House of Stuart who coincidentally wrote and thought in another language. Whatever their motivations, what ultimately united both British 
royalism also incorporated several potentially conflicting rationalizations. Some poets, most notably Vondel, embraced the 'absolutist' royalism that was abhorred by republican thinkers such as Milton and Schele, but which was a far cry from more moderate forms of royalism. ${ }^{20}$ Others, such as Jan Zoet or Lambert van den Bosch, as well as Huygens, were driven by their Orangism-which in Huygens's case was supplemented with a personal loyalty to the king of England. Remonstrants and Catholics (Oudaen, Brandt, Naeranus) were united in their abhorrence of English Puritanism, which-not entirely without reason-they associated with their Dutch religious adversaries, the Counter-Remonstrants.

The major triumph of the Stuart propaganda was that it managed to unite these various groups and to make them forget, or at least be silent about, those aspects of royalism they did not like. ${ }^{21}$ Salmasius found a way to tap into different religious and political sentiments, and to bring them together in a way that may have appeared logically flawed to the minds of scholarly thinkers such as Heinsius, ${ }^{22}$ Schele, ${ }^{23}$ and Milton, but which made great sense from the iconological viewpoint of mainstream poetic culture. His highly rhetorical use of the term 'parricide' for the execution of Charles I, for instance, provoked Milton's scorn ('Our fathers begot us. Our king made not us, but we him'), but the characterization had an immense iconic value in the patriarchal seventeenth century and was adopted by many Dutch poets immediately after the regicide. It placed the King's death in a line of infamous murders on heads of state, including Julius Caesar, William the Silent and Johan van Oldenbarnevelt. The parallel with that most recent 'father', Oldenbarnevelt, especially appealed to Dutch Remonstrant and Catholic poets, including, as we shall see, Joan Dullaert and Joost van den Vondel. The royalist propaganda to which Salmasius

and continental royalists was their zeal to restore Charles II to the thrones of England and Ireland.

${ }^{20}$ On Vondel's (theoretical) monarchism, see Van Dijkhuizen and Helmers, 'So Shall the World Go On'.

${ }^{21}$ Joachim Oudaen is known to have regretted the plays and poems he wrote in support of the Stuart cause in later life. Cf. Melles, Joachim Oudaan, pp. 64-66.

${ }_{22}$ In a letter to Gronovius, Heinsius famously wrote that Milton had pleaded an evil cause well, whereas 'Scribonius [Salmasius] has pleaded most abominably the cause of the unfortunate king'. Cited in Scherpbier, Milton in Holland, p. 10.

${ }^{23}$ Radboud Herman Schele wrote a fierce reply to Salmasius, De iure imperii, which was, however, published posthumously after the Restoration. See Schele, De jure imperii liber posthumus, ed. by Th. Hogers (Amsterdam: Elsevier, 1671). 
contributed effaced ideological conflicts with time-tested analogies and imagery. ${ }^{24}$ Throughout the 1650 s, the theatrical and iconographical aspects of the Stuart cause continued to outweigh any sustained republican or Calvinist argument against it. ${ }^{25}$

The portrayal of Charles I as a political and religious martyr in Eikon Basilike (Portrait of the King, 1649) is doubtless the best known example of the literary power of royalist propaganda. Gauden's book paved the way for the cult of Charles I, and eventually his canonization. ${ }^{26}$ The image of Charles as a Davidic, god-fearing king was dissipated through countless editions of the Eikon in English as well as in the continental vernaculars, ${ }^{27}$ and soon multiplied by numerous poets, including many Dutchmen. Even the analogy with the passion of Christ, implicit in the Eikon, but common enough in the early cult, was frequently accepted in Dutch poems. When Anslo, Brandt, Six van Chandelier, and many others alluded to Charles's imitatio Christi, they were following Gauden's lead, and considering the notoriety and the availability of the book, it is scarcely conceivable that they were doing so unwittingly. ${ }^{28}$ Salmasius, too, employed the image, but he added an element that was absent or perhaps implicit in the Eikon: retaliation.

This article explores the royalist rhetoric of revenge that was employed by Dutch poets and playwrights in response to the regicide, in some cases before the publication of the Defensio, but mostly after it. In order to propagate the revenge of Charles II, these poets drew on the language and conventions of Senecan revenge tragedy. This genre was specifically suited to poets commenting on the English Civil War and the regicide, because it had always investigated the themes of tyranny, rebellion and (divine) justice, and had often pointed out the

${ }^{24}$ As Andrew Lacey writes with regard to Charles I's martyrdom: 'the theology and iconography of martyrdom it drew upon were common property [...] in the seventeenth century'. See Lacey, The Cult of Charles the Martyr, p. 9.

${ }^{25}$ Kevin Sharpe, 'An Image Doting Rabble', has even argued that the failure of the English Republic to find a convincing alternative to the powerful royalist imagery ultimately caused its downfall.

${ }^{26}$ Lacey, The Cult of Charles the Martyr is the definitive work about the cult and its cultural contexts in England.

${ }^{27}$ For the continental reception of the Eikon, see Madan, A New Bibliography and Gerritsen, 'The Eikon in Holland'.

${ }^{28}$ Geeraerd Brandt, 'Op de print van de Koningh van Engelandt,' Salmasius, Koninklijkke verdediging, voor Kaarel den I. (Rotterdam: Naeranus, 1650), p. ${ }^{*} 6^{\mathrm{v}}$; Jan Six van Chandelier, Rariteiten te koop (n. 17 above); Anslo, Kroonrecht door gewelt verkracht (n. 18 above). 
similarity between revenge and civil war. ${ }^{29}$ To royalists, I will argue, it held a special appeal, because it was so easily integrated with the existing royalist iconography of the martyr king.

Topical appropriations of revenge tragedy reveal the extent to which Dutch literature of the period was engaged in political debate. It also shows the potential tensions that existed between an international political discourse and domestic politics. In the context of the States of Holland's persistent attachment to their policy of neutrality in the British conflict between King and Parliament-even during the first Anglo-Dutch war of 1652-1654-the literary support for the Stuart King in exile was problematic, and, as I will show, downright subversive at times of crisis. The fact that the royalist plea for revenge was so easily translatable into Senecan language and images also points towards a more fundamental interaction between literature and politics in this period of intense strife between monarchs and councils. The attraction of the royalist cause partly rested on the theatricality of kingship, and the dramatic appeal of the regicide only reinforced this attraction. But conversely, literary genres such as the martyr play and revenge tragedy also tended to favour monarchism. In the Dutch Republic of the first stadtholderless period, the abundance of royalist poetry and drama testifies to the cultural appeal of kingship, and the weakness of republican culture, as even republican poets such as Oudaen were attracted by the poetic and theatrical appeal of the King's cause. ${ }^{30}$

\section{The Ghost of Charles I: Martyrdom, Senecan Horror and the Stuart Cause}

The juxtaposition of the martyrdom of Charles I with a rhetoric of revenge may perhaps best be illustrated by Joan Dullaert's martyr play Karel Stuart of Rampzalige Majesteyt (Charles Stuart or Disastrous Majesty, written 1649, printed 1652, performed 1653). Written directly after the regicide in 1649 , this tragedy is a rather straightforward dramatization of the Eikon Basilike. Like the Eikon, Dullaert's play represents the King's trial and execution as an imitatio Christi, tracking his development from initial despair in the first act to trium-

\footnotetext{
${ }^{29}$ Cf. Kerrigan, 'Revenge Tragedy Revisited'.

${ }^{30}$ I rely here on Kevin Sharpe's argument with regard to England; see his 'An Image Doting Rabble'.
} 
phant piety and resignation in the last. ${ }^{31}$ But although vengefulness is far from Charles's mind in the action of the play-as in the Eikon he even forgives his executioners and prays for their salvation ${ }^{32}-$ it is not absent from the play. Converting her grief into anger (as revenge tragedy requires) the princess Elizabeth cries, 'The blood flowing from his severed neck / cries woe and vengeance for the supreme God / and makes the Heavens thunder'. ${ }^{33}$ In Elizabeth's moving complaint, avenging the martyr king is a religious act, done in the service of God. The play, which shows Charles's conformity with Christ, thus ends on a note of retaliation.

Vengeance was also prominent in the prefatory poem that Dullaert added to the first publication (1652) of his martyr play. The poem in question is a rather quaint sonnet which negates the image of the meek monarch and focuses on his ire. ${ }^{34}$ Heavily drawing on Senecan imagery, it describes how, ten days after the trial, the ghost of the decapitated King appears before the judges who convicted him. With a withered appearance, fiery eyes and blood dripping from his hair, the ghost terrifies John Bradshaw and his Council. When they attempt to flee,

At once his head he from his severed neck did raise Which, with an open mouth, and very crampèd face Thrice for vengeance cried: the judges' hair stood on end.

Blood spilled freely from his corpse; and with a sad lament And mournful wail, he quickly vanished from their sight But in his place did leave, soul-sickening woe, and fright. ${ }^{35}$

${ }^{31}$ The main sources of the play are: Eikon Basilike [Dutch titles: Konincklick Memoriael (Hartgers, 1649) and Koninclijck voorbeeldt (Naeranus, 1650)], Engelsch Memoriael, and Vondel, Maria Stuart (1646).

32 'Ach Vader, wil u doch ontfarmen, / Met dees verweze Majesteit. / Vergeef het hen die my mishandlen, / En leer 'er 't padt des deuchds bewandlen'. Dullaert, Karel Stuart, p. I $1^{\mathrm{r}}$.

33 'Het bloed uit zijn doorkurve strot / Roept: wee en wraak voor d'Oppergod, / En doet den gantschen Hemel dav'ren'. Dullaert, Karel Stuart, p. K2 ${ }^{v}$. In poems by Westerbaen and several anonymous poets, the cry for vengeance is also articulated by the King's grieving relatives. See, for example: Knuttel, 6336, Jacob Westerbaen, Klachte van Henriette de Bourbon, Koninginne van Groot-Brittanjen over de dood van den doorluchtigsten en ongelukkigsten Koning Karel haren man (1649); Thys., 5370, [Cornelis van Beveren] Klachte Elizabets, Coninginne van Bohemen (1649); and Knuttel, 6333, Henriette de Bourbons ontstelde-Groot-moedigheid (1649).

${ }^{34}$ For a short account of this prefatory sonnet, see Duits, 'Horror als voorafje: de "Voorzangk" bij Joan Dullaarts Karel Stuart'.

${ }^{35}$ Karel Stuart, p. A1 , my translation. The Dutch original reads: 'Met beurde hy zijn hooft van d'afgehouwe nek, / Dat met een open mondt, en heel benaauwd een trek, / Tot driemaal riep om wraak: des de moorders hairen rezen. // Het bloedt sprongk uit 
This, obviously, is the language of revenge tragedy. In his article on this poem, Henk Duits has proposed that the ghosts of Shakespeare's Old Hamlet and the brother of Geeraerdt van Velsen in P.C. Hooft's tragedy Geeraerdt van Velsen were the sources of Dullaert's horrific ghost, but obviously, Thyestes' ghost in Seneca's Agamemnon, as the common ancestor of all the revenge ghosts he mentions, is the more likely candidate. The direct literary model for Dullaert's sonnet, however, is neither Shakespeare nor Seneca, but Vondel.

In the preliminary pages of Palamedes (1625/6) Vondel too had conjured up the horrifying ghost of his titular hero who visited his judges. The close similarities between Vondel's prefatory poem and Dullaert's are unmistakable. Besides the sonnet form, the content of Vondel's poem is strikingly akin to Dullaert's. Like the ghost of Charles I, Vondel's Palamedes is covered with blood, he is abused, 'black and blue', and when his waking judges see him, their reaction closely resembles that of Bradshaw and his fellows:

They trembled with fear, fled not, rather flew Then hence, then there, for his burning eyes.

He followed them, and left a bloodstain where he went $[\ldots]^{36}$

At the end of Vondel's poem, as in Dullaert's, Palamedes's ghost has left the 'parricides' to their own fears, to 'gnaw' at their own hearts.

The fact that Dullaert intertextually referred to the preliminary matter of Palamedes when he wrote his own sonnet about the ghost of Charles I is significant, because Vondel's tragedy was widely recognized as a political allegory, in which Vondel depicted Johan van Oldenbarnevelt/Palamedes as the innocent victim of the cruel ambition of François van Aerssen/Ulysses, Agamemnon/Maurits of Orange and the judges who convicted him. ${ }^{37}$ Dullaert's echoing of Palamedes, then, suggests that the execution of the English king in 1649 reminded him of the death of the old Grand Pensionary of Holland in 1619. He

de romp, en met een droef gesteen, / En jammerlijke galm, hy flux van hen verdween, / Doch liet er, in zijn plaats, zielknagend' wee, en vrezen.'

${ }^{36}$ Vondel, 'Klinkdicht', Palamedes of Vermoorde onnozelheit: Treurspel: Nunc cassum lumine lugent (Amsterdam: Abraham de Wees, 1652), p. B1 $1^{\mathrm{r}}$. Translated from the original Dutch: 'Zy sidderden van schrick: zy vloden niet, maer vloogen, / Dan ginder heen, dan hier, voor't branden van zijne oogen. / Hy staptze na, en liet een bloetvleck waer hy tradt'.

${ }^{37}$ The allegory was instantly decoded by Vondel's contemporaries and brought Vondel into conflict with the authorities. In the 1707 'Amersfoort' edition of Palamedes, the allegory is explained in the notes. 
was not the only one. The execution of Oldenbarnevelt had been a traumatic affair, which for the Remonstrants had become emblematic of the internal religious and political conflicts that continued to haunt the Dutch Republic in the 1650s. The implication of Dullaert's allusion to Palamedes, therefore, is that both executions were comparable, and that the disruptive forces of domestic conflict that brought them about were similar.

The comparison between Oldenbarnevelt and Charles I was invited in other ways as well. Cromwell was commonly associated with Ulysses, Palamedes's main opponent who feigned religious scruples to hide his burning ambition. ${ }^{38}$ Indeed, in the play itself, Dullaert frequently called Cromwell 'a Ulysses'. Vondel's choice of words, too, was suggestive in the context of the aftermath of the English regicide. The judges of Palamedes/Oldenbarnevelt are called 'patricides' ('vadermoorders') and 'wolves' ('wolven'), for instance, precisely the terms propagated by Salmasius and reiterated by Vondel and many other Dutch poets to denounce the regicides. The very Senecan rhetoric Vondel-himself probably inspired by Samuel Coster's Iphigenia (1617) - had used against the Counter-Remonstrants in the 1620s, then, needed to be only slightly modified by Dutch Remonstrant royalists to become applicable to the English regicides. Time and again they would conflate the executions of 1619 and 1649 by using the same poetic material. A 1657 pamphlet even cited both Coster's Iphigenia and Vondel's translation of Seneca's Troades, his Amsteldamsche Hecvba (Amsterdam's Hecuba, 1626) in order to align the parricidal Cromwell with the Counter-Remonstrants. ${ }^{39}$ When no less than four new editions of Palamedes were printed by Abraham de Wees straight after the outbreak of the first Anglo-Dutch War in 1652, the play simultaneously activated two contexts: the Dutch Truce Conflicts and the English Puritan revolution and regicide, thereby offering an interpretative framework that held a distinct, religious appeal to Dutch Remonstrants in their ongoing conflict with the strict Calvinist establishment. Politically, however, their adoption of a dynastic perspective instead of that of the States of Holland was less obvious.

\footnotetext{
${ }^{38}$ Grosheide, Cromwell naar het oordeel van zijn Nederlandse tijdgenoten.

${ }^{39}$ Knuttel, 7822, Vergelijckinge tusschen Claudius Tiberius, Kayser van Romen, en Oliver Cromwel, Protector, of misschien toekomenden koninck van Engelandt, \& c. (1657).
} 
The literary model of Dullaert's paratext reveals that the Dutch response to the regicide at times echoed Remonstrant poetry pertinent to the religious strife within the Netherlands. Yet Dullaert's ghost also had distinct political connotations, which are brought out by topical pamphlets on the regicide. The vengeful, Senecan ghost of the decapitated King appeared in many pamphlets and poems in the early 1650s. In the pamphlet Wonderlijcke Geest des Conincx [...] wraeck begerende over eenen Jan Coke Advocaet, ende soliciteur voor den Republijcke van Engelandt (Miraculous Ghost of the King [...] Desiring Vengeance over John Cooke, 1649), for example, the ghost of Charles I appears to John Cooke, the solicitor-general for the Commonwealth who acted as the King's prosecutor during the trial in January $1649 .{ }^{40}$ Pamphlets like these provide an illuminating context for Dullaert's sonnet, as they suggest that the vengeful ghost of the King had a distinct persuasive, and hence political, function.

This is best illustrated by a similar pamphlet with the telling title $D e$ geest van Karolus Stuart verscheenen aan de Nederlanden (The Ghost of Charles Stuart Appearing to the Netherlands, 1649), which depicts Charles very much like Dullaert's ghost: as a bloody corpse carrying its own head. ${ }^{41}$ Here, however, the decapitated king does not terrify his judges, but rather his Dutch audience, as he complains about William II's sluggishness in coming to avenge him, and implores William to make haste. Was this a royalist critique of the stadtholder? Or was it rather an encouragement, and an attempt to prepare the minds of its Dutch audience for war? Possibly it was both. In any case, the poem employs a generic, literary image in order to argue for Dutch intervention in England. Whereas the image of the passive Martyr King provided Charles with a divine aura, and was tailored to arouse pity, representations of the King's vengeful ghost were specifically suited to being a call for action aimed directly at a Dutch audience.

The Ghost of Charles Stuart's explicit appeal to William II of Orange is implicit in many Dutch visions of a Stuart revenge in 1649-1650. Before he died suddenly of smallpox in November 1650, all royalist hopes centred on the young stadtholder William II, brother-in-law to Charles II. As indicated above, William held on to two firm principles

${ }^{40}$ Knuttel, 6328, Wonderlijcke Geest des Conincx, Coninck over Engelandt, Schotlandt, en Eyrlandt, wraeck begerende over eenen Jan Coke Advocaet, ende soliciteur voor den Republijcke van Engelandt (1649).

${ }^{41}$ Knuttel, 6363, De geest van Karolus Stuart verscheenen aan de Nederlanden (1649). 
in his foreign policy: to renew the war with Spain (which had ended with the Peace of Westphalen in 1648) and to support the Stuart cause. Eager to advance his own dynastic interests, William plunged himself and his House into debts on behalf of his royal friends. However, his own fortune (or rather credit) did not suffice to decide the struggle, and he was therefore continuously striving to gain domestic support for a war with the Rump and a renewed war with Spain. War, however, required the backing of the States General, and although William controlled most of the voting provinces, he was frustrated by the States of Holland, who had the power to block any decision of the general assembly. Holland and, initially, Zeeland treasured the English market and feared the effects of Parliament's strong navy on their trade in case of war. The States of both provinces had been determined to remain neutral in the English conflict during the 1640s, and continued this policy after the regicide. If the United Provinces were to put their weight behind the royalist cause, the States of Holland would somehow have to be forced to comply. William's raid on Amsterdam, in the summer of 1650, an audacious attempt to subdue the States of Holland and to gain complete control over the Republic, was instrumental in achieving this goal. ${ }^{42}$ Stirring up royalist sentiments among the populace was another, slightly more subtle, means to the same end. In 1649-1650, royalist visions of revenge were of special significance in the Dutch political context as they were aimed against, and designed to overcome, Holland's policy of neutrality.

The obvious problem with the Senecan rhetoric of vengeance as adopted by Dullaert and many pamphleteers, however, was the doubtful moral nature of revenge. Dutch revenge tragedies tended to emphasize unambiguously the fact that revenge belonged to God. Jan Vos (the playwright who had introduced Shakespeare's Titus Andronicus to the Amsterdam stage and the Dutch master of revenge tragedy) clearly recognized this problem. In the 20 sestets comprising Brittanje aan Euroope (Britain to Europe), Vos introduced Britain as a Senecan character rousing Europe to avenge Charles I. ${ }^{43}$ Dressed in black (very

\footnotetext{
${ }^{42}$ See for instance Groenveld, De Prins voor Amsterdam, pp. 13-22 and Kernkamp, Prins Willem II. 1626-1650, pp. 78ff.

${ }^{43}$ Jan Vos, 'Brittanje aan Euroope, toen Koning KAREL D'EERSTE vermoordt, \&c', in Salmasius, Koninklijkke verdediging, voor Kaarel den I (Rotterdam: Naeranus, 1650), KV, pp. ${ }^{\star \star} 5^{\mathrm{r}}-^{\star *} 8^{\mathrm{r}}$. The poem also appeared in Verscheyde Nederduytsche gedichten (Amsterdam: Lodewyck Spillebout, 1651), pp. 79-82 and Jan Vos, Alle de Gedichten van den poëet Jan Vos (Amsterdam: Jacob Lescaille, 1662), pp. 463-67.
} 
much as Princess Elizabeth in Dullaert's play) Britain told the continent to mourn no more, but to rise to action and punish the regicides (ll. 1-6). The blood is already dripping in the first few lines, but Vos further enhances the horror of his poem in the fifth sestet, where he has Britain describe the continental army she envisages (1l. 31-36):

With tendons tightly stretch Lord Strafford's skin ${ }^{44}$

About his skull; scare the cruel tyrants

And use his shins to strike the fearful drum

You'll blow the hollow bones as you march on,

Fairfax will be surprised by such a sound

Of war, which will make his army flee. ${ }^{45}$

Political retaliation is here couched in the language of revenge tragedy, the genre that earned Vos his reputation, and it is difficult to read this passage and its imaginative use of Strafford's body parts, without being reminded of Titus's revenge ('Hark, villains, I will grind your bones to dust, / And with your blood I'll make a paste / And of the paste a coffin I will rear'). ${ }^{46}$ Through this kind of verse, English revenge tragedy was recycled on the political stage, and applied to the English context. Interestingly, Vos explicitly states that moral reservations about revenge should now be temporarily put aside (1l. 103-05):

Vindictiveness, which long was libelled devilish

Shall now be divine; for they who corrupt the law

And shed the royal blood, deserve the heaviest punishment. ${ }^{47}$

${ }^{44}$ The execution of the Earl of Strafford, Charles I's viceroy of Ireland, at the behest of Parliament in 1641, had been a traumatic affair for the king, who had been forced to sign the death warrant of one of his most loyal friends. After 1649, Strafford's death was usually seen as a pre-figuration of the King's, and the fact that Vos commemorates him in this context shows that he too absolved the king from any responsibility. By contrast, the campaign he envisages enables the royalists to avenge Strafford as much as the King.

${ }^{45}$ Translated from the original Dutch: 'Gy zult mijn Strafforts huit, tot schrik der wreê tirannen, / Op Strafforts bekkeneel met taie peezen spannen, / En slaan met zijn gebeent op zulk een trom voor't volk; / In't trekken zult gy op zijn holle schonken blaazen; / Want zulk een krijgsgerucht zal Fairfax zelf verbaazen; / En 't leeger wegh doen vliên'.

46 Vos's rendering of this passage in Aran en Titus: 'Dies zal ik u de neus flux uit uw' aanzicht bijten, / En al wat manlijk is van uwe lichaam rijten, / En stroopen u de huidt, al leevendig van 't lijf, / En steeken u aan 't spit; en schaffen 't helsche wijf, / Uw' godvergete moêr, de gaargebraaden schinken: / En geeven haar uw' bloedt, met wijn doormengt, te drinken' (ll. 1887-92).

${ }_{47}$ Translated from the original Dutch: 'De Wraakzucht die altijdt voor duivelsch is gelastert, / Die zal nu godtlijk zijn; want die de wet verbastert, / En 's Koninx bloedt vergiet, verdient de zwaarste straf'. 
If Dutch audiences were to be convinced that they should ally themselves with Charles II, vengefulness, according to Vos, had to be re-evaluated. Hence, the image of the ghost of Charles I was complemented with images of his son as a just avenger.

Vos's Britain to Europe was first published as a prefatory poem in the Dutch edition of Salmasius's Defensio Regia and as such it both illustrates and reinforces one of the central arguments in that key text for royalist propagandists. The problem with which both Salmasius and Vos were struggling was essentially biblical in nature. The idea that God would be avenged on the regicides because they had violated the Divine Right of Kings was founded on several favourite biblical places of royalist Divine Right advocates, such as 1 Peter 2:17: 'Fear God, honour the King'. However, unambiguously anti-revolutionary as such royalist slogans may have been, they did not necessarily imply that Charles II was a just avenger. In his Defensio Regia, Salmasius cited Romans 12:19-13:1 to make that point:

Let every soul be subject unto the higher powers. For there is no power but of God: the powers that be are ordained of God.

(...)

.... if thou do that which is evil, be afraid; for he beareth not the sword in vain: for he is the minister of God, a revenger to execute wrath upon him that doeth evil. ${ }^{48}$

This biblical dictum, so central for royalists, shows that thinking about tyranny, obedience and revolution was very much intertwined with thinking about revenge, as the divine ruling against revolution was immediately followed by the warning that the rightful ruler was God's avenger ${ }^{49}$ In Salmasius's reading, there was no distinction between divine vindication and the revenge of Charles II, because Charles was merely God's avatar. Obviously, Vos's argument-albeit implicitlyrelied on the same biblical context.

Yet both Salmasius and Vos glossed over one essential crux. In the case of civil war, when two or more authorities contest the sovereignty or rightfulness of the other(s), Romans 12-13 became utterly ambiguous, as the question as to who 'the powers that be' actually were was exactly what was at stake. If ultimate authority was to be found in Parliament, it was Parliament that would wield the sword of wrath, not

${ }_{48}$ Salmasius, Koninklijkke verdediging, voor Kaarel den I., p. 92.

${ }^{49}$ Kerrigan, 'Revenge tragedy revisited'. 
the king in exile. Indeed, in the First Defence, Milton characteristically reversed Salmasius's argument by claiming that in the commonwealth, all the magistracy are by [God] entrusted with the preservation and execution of the laws, with the power of punishing and revenging; he has put the sword into their hands'. In Milton's reading, Paul's sword of wrath was the blade that had severed the king's head from his neck. ${ }^{50}$ Even before Milton's reply, Salmasius knew that such a 'mad' interpretation of Paul's letter to the Romans was current among 'the prophets of England'. Yet he could never accept the authority of Parliament and therefore had to replace 'magistracy' with 'people' before he could rhetorically ask: 'who are the people they adorn with the name of power? Is it the entire people or a part of it? If entire, who are then to obey them? If a part, which part?'51 While reflecting on Salmasius's concern with revenge, Vos confronted the ambiguities of Paul's letter to the Romans in another way. By inscribing Charles I and Charles II into the genre of revenge tragedy, he could rely on the emotive power and authority of the form. The drama had always distinguished between bad avengers such as Aran and Tamora-who are driven by devilish ambition and deplorable vindictiveness - and good avengers, such as Lucius Andronicus, who are basically restorers of (divine) order.

Stuart political discourse and the dramatic genre of revenge tragedy, then, were confronted with the same moral ambiguity rooted in the Bible. Representing Charles as a generic, indeed iconic avenger was a means of effacing that ambiguity. In the elaborate allegorical

${ }^{50}$ Milton, First Defence, Chap. 3. Emphasis added. The entire passage shows that, for Milton, the magistrates act as defenders of the ultimate authority, religion. The church and the faithful need them as sword-bearers: 'God has not so modelled the government of the world as to make it the duty of any civil community to submit to the cruelties of tyrants, and yet to leave the church at liberty to free themselves from slavery and tyranny; nay, rather quite contrary, he has put no arms into the church's hand but those of patience and innocence, prayer and ecclesiastical discipline; but in the commonwealth, all the magistracy are by him entrusted with the preservation and execution of the laws, with the power of punishing and revenging; he has put the sword into their hands.'

${ }^{51}$ Salmasius, Koninklijkke verdediging, voor Kaarel den I, pp. 100-01. Translated from the original Dutch: 'Daar is een raazende uytlegginge der waarseggers van Engeland, van het gebod van Paulus, daar hy gebied, dat sy alle de machten onderworpen sijn, ende vermaanende, dat de macht van God gestelt is, niet te wederstaan is. Want dese macht verstaan sy van het volk. [...] wat is dat voor Volk dat sy met de naam van macht willen verstaan hebben? het geheele volk of een deel des selfs? Indien het geheele, wie sullen die sijn die het volk sullen moeten gehoorzamen [...]? Indien een deel, van wat deel sullen sy dat uytleggen?' 
engraving on the broadsheet pamphlet called Het Toneel der Engelsche Elenden (The Stage of English Miseries) (see illustration 1) the idea that Charles II was part of a divine revenge plot is pointedly illustrated. ${ }^{52}$ Charles is here shown as a personification of St. George who fights the seven-headed dragon of revolution with a sword labelled 'Crown Right'. Ireland and Scotland kneel before him, and while Ireland appears to strap on his armour, Scotland hands him a gun that has two barely legible words written on it: 'provoked revenge' ('geterghde wraeck'). ${ }^{53}$ Charles's revenge is justified by the depiction of the execution of his father in the background. Dark clouds hang over the scaffold, yet it is lit up by four beams that testify to God's anger, his grief, and his pending revenge. Two read: 'Ire of God' ('Gramschap Gods'), the other two 'Woe, Woe' ('Wee-wee'), and: 'Revenge, Revenge' ('Wraak-wraak'). Above the armies fighting in heaven (a reference to the reported sightings in England of battles in heaven during the Civil War), small but central, is God's shining sword of wrath. Charles II has here become the chosen scourge of God.

Such divine support for royal revenge may also be found in one of the most outspoken political appropriations of Senecan revenge tragedy in seventeenth century Dutch drama, Jan Bara's Herstelde Vorst, ofte geluckigh ongeluck (Restored Prince, or Fortunate Misfortune, 1650). ${ }^{54}$ Bara presents us with a British prince in mythical times called Rasimo, who is, early on in the play, visited by the ghost of his murdered father who rouses him to avenge his death: 'Satisfy my plea, go! Revenge!

52 Jan Zoet, Het Tooneel der Engelsche elende (Amsterdam: Hugo Allard, s.d.). Amsterdam, Rijksmuseum, FM2054a. See also: British Library, Thomason 669f12 (88). EEBO 122153. Atlas van Stolk, nr. 2157. Van Kuyk mentions the pamphlet in his Oude politieke spotprenten, pp. 17, 152. See also: The Abraham Cowley Text and Image Archive (last accessed 31 March 2008): <http://etext.virginia.edu/kinney/small/ turningworm.htm>. See also Cordes, Jan Zoet, pp. 265-67.

53 The presence of Ireland in a role facilitating revenge suggests that the engraving was made before October 1649, by which time Cromwell had subdued Ireland. More likely, however, the pamphlet dates from early in 1650, when Charles agreed to the Scottish Covenanters' demands and became King of Scotland, which finally enabled him to come to action after having been stuck in Jersey for months. Because a second state of the plate shows Charles's coronation as King of Scotland, on 1 January 1651, Het Tooneel must have been in existence before that date. Of course, this does not rule out later reprints. Van Kuyk, Oude politieke spotprenten, p. 152, erroneously dates the broadside 1652; the Atlas van Stolk (Rotterdam: Atlas van Stolk, 1976) has 1651.

${ }^{54}$ Jan Bara, Herstelde Vorst, ofte Geluckigh Ongeluck (Amsterdam: L. Spillebout, 1650). I used the copy of the Royal Library in The Hague, sig. 760 E 69. 


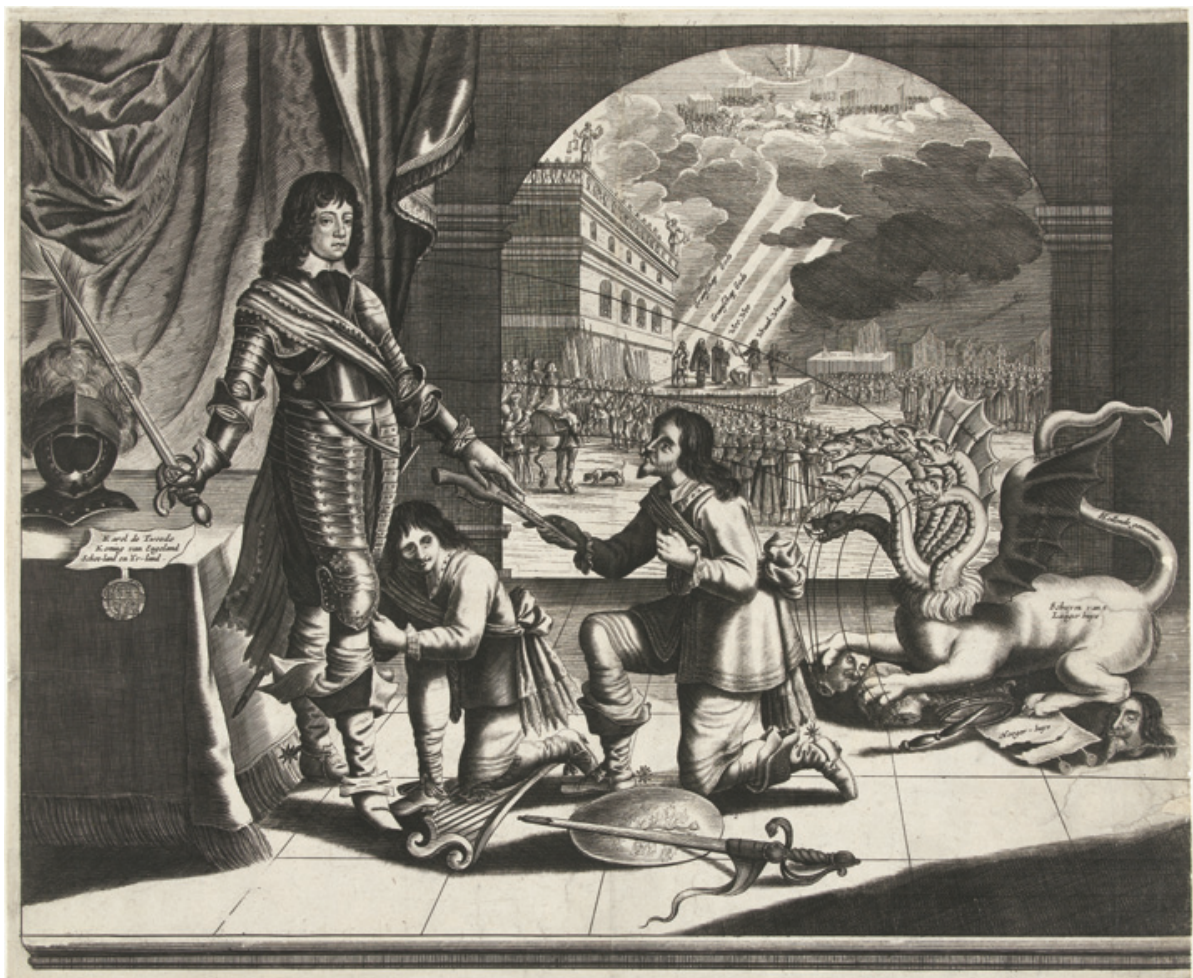

HET TOONEEL DER ENGELSCHE ELLENDEN

Ill. 1. The Stage of English Miseries (Amsterdam: Hugo Allard, 1650). Courtesy of the Rijksmuseum, Amsterdam (FM2045a). 
Revenge! O, melancholy son!' the ghost cries. ${ }^{55}$ Rasimo, however, is hesitant to perform the revenge requested by his father. As a result of his hesitance, disaster strikes. In the end of the play, Ferrugo, a devilish captain in the English army, is able to cause a 'terrible pestilence' to settle 'in the country's marrow'. Eventually Rasimo is happily restored to the throne. Yet all is not well, as appears when another ghost arrives to bring an ominous prophecy to the decimated British court:

Here shall the axe be crimsoned by the Vice-Roy's blood

The Archbishop's head, and the King's, shall be cut off

On this scaffold. Cold steel will run through their necks

To Holland's great dismay, and France's bitter grief;

Live long in peace, but mind the godforsaken heirs

Of this cruel captain. ${ }^{56}$

Bara's play abounds with topical allusions to the recent horrors of Civil War in England and its allegorical quality would not have been lost on contemporary readers and audiences. Captain Ferrugo, the devilish intriguer, is clearly a pre-figuration of Parliament's martial heroes, Cromwell and Fairfax. Rasimo, on the other hand, is of course a type of Charles II, or, as the Ghost of Charles Stuart suggests, William II. When the main issue addressed by The Restored Prince, the question of whether the protagonist has the right to revenge his murdered father is answered unambiguously by a Voice from Heaven (which encourages Rasimo to pursue his just cause), this is not only a justification of Rasimo's subsequent acts of revenge, but also of a royalist invasion of Parliamentary England.

With the exception of the more or less happy ending, the plot summary of The Restored Prince is, of course, vaguely familiar. And indeed, shades of Hamlet are present throughout the play. As in Dullaert's sonnet, the similarity is probably coincidental. Seneca's Agamemnon, in which the ghost of Thyestes pressures his son Aegisthus to revenge, is again the more likely source for the ghost, whereas with respect to the hesitant son Bara may even have been inspired by Geeraerd Brandt's

\footnotetext{
${ }^{55}$ Herstelde vorst, p. A2v', my translation. Orig. 'Voldoe mijn beê, op! wraeck! wraeck! ô bedruckte Soon!'

${ }_{56}$ Translated from the original Dutch: 'hier de Vice-Roy [Strafford] de bijle sal bebloeden, / Daer 't hooft van Cantelbergh [Laud], en 's Konings [Charles I] sijn geknot / Het stael door strot en neck gedreven op't schavot, / Ten rou in Hollandstuyn, en druck in't Hof der Vrancken; / Leef lang in vreê, maer straft de god-vergete rancken / Van dese Capiteyn.'
} 
popular Veinzende Torquatus (Feigning Torquate, 1644), which also closely resembled Hamlet, yet is widely believed to be a dramatization of one of Bandello's Tragic Histories. Nevertheless, Bara's echoing of Shakespeare is important in the sense that it shows how the royalists' appropriation of revenge tragedy interacted with existing discourses of revenge. For those who had read or seen topical plays like The Restored Prince, or even pamphlets like The Ghost of Charles Stuart, Hamlet or indeed any other Senecan revenge tragedy would have acquired poignant topical overtones.

Very similar to Bara's Restored Prince is Lodewijk Meyer's Verloofde Koningksbruidt (The Royal Bride, w. 1652), which also tells the story of a mythical regicide in Britain, followed by a complex revenge plot. The Royal Bride is vintage Senecan revenge tragedy in overdrive. Besides a Hamlet-like plot in which the ghost of the father is actually a disguised cousin of the avenger, it contains a cannibalistic scene in which the tyrant of Britain unwittingly drinks the blood of his murdered sons for wine-an obvious borrowing from Jan Vos's Aran en Titus. ${ }^{57}$ Despite the onslaught at the British court, however, all ends well. Consider how one of the remaining noblemen introduces the rightful king, Atelstan, as a deus ex machina at the end of The Royal Bride:

My Lords, do not doubt that this is the Royal son Our firstborn Prince, and the lawful heir to the throne.

Having the Tyrant's sword escaped, he kept himself

With this dear Queen concealed in Caledonia

All the while he patiently plotted with me

To force, with violence or craft, this raging tyrant

From his throne, and avenge his noble family. ${ }^{58}$

In 1652, when Meyer wrote his play, there was only one king of Britain who had recently found shelter in Caledonia. And if Atelstan is, like Rasimo, a type of Charles II, it understandable that Meyer foregrounded the Queen of Caledonia as the 'royal bride' of the play's title:

${ }^{57}$ Meyer's editors offer evidence of several traces of Aran en Titus in Meyer's play and prefer it to Seneca's Thyestes as the source for the cannibalistic scene. Lodewijk Meyer, Verloofde Koninksbruidt. Aran en Titus, 1l. 45-47.

${ }_{58}$ Meyer, Verloofde Koninksbruidt, pp. 153-54, ll. 1817-23. Translated from the original Dutch: 'Ghy Heeren, twijffelt niet; deeze is de Koningszoon, / Onze erffelijke Vorst, en wettigh oir der kroon, / Die, 't zwaerdt van den Tiran ontvlucht, zich by Mêvrouwe, / In Kaledonien, bedekt'lijk heeft ghehouwen, / En onderwijl met my staâgh onderling verstandt / Om met gheweldt, óft list, den woeden Dwingelandt / Te bonzen van den troon, en zijn gheslacht te wreeken'. 
by emphasizing the unwavering love and loyalty of the only Scottish character in the play to the lawful heir to the throne, Meyer celebrated the 'marriage' between Charles II and Scotland.

In the Dutch context, that 'marriage' was of particular importance. William II had engineered Charles II's agreement with the Scottish Covenanters in order to sway Calvinist opinion on his support of the Stuart cause. A war on behalf of a Presbyterian king would be easier to sell than a war on behalf of an Episcopal one. Dutch pamphlets frequently celebrated Charles's acceptance of the Scottish crown as a harbinger of his revenge on the regicides. The fact that his revenge would now also be a solid Protestant revenge was most pointedly illustrated in the second state of The Stage of English Miseries, which accompanied a description of the coronation (see illustration 2). ${ }^{59}$ In this version, Charles is still prominently depicted as a generic avenger, but instead of the execution of his father, the background shows his coronation by the Marquess of Argyle. Moreover, he is now accompanied by the Church of Scotland minister Robert Douglas, who is reading a text captioned 'Proverbs 1:12': 'Let us swallow them alive'. Douglas's sober, Presbyterian attire serves to show that the aggression of his new son-king originates in a justified Protestant desire to punish the sinners to which Salomon's text refers. The Scottish alliance, then, offered hope for a happy ending in more than one way. But the religious sensitivities surrounding an allied Orange-Stuart revenge, which were highlighted by it, were sensibly glossed over by Meyer and his fellow playwrights in the early 1650s. The Royal Bride merely opposes Scotland's loyalty to the usurpation in England; the Scots' religious identity remains mythically irrelevant to the poetic scheme of things.

\section{The Stuart Revenge and the Anglo-Dutch War}

The stadtholderless period, which began after William II's death on 6 November 1650, meant that Dutch assistance in a Stuart campaign was further away than ever. The States Party in Holland was now able to uphold its policy of neutrality in the English conflict without coordinated political resistance. The Stuart rhetoric of revenge had

\footnotetext{
${ }_{59}$ Atlas van Stolk 2158. Kunstig vertoog en bondig verhaal van de krooning van zijne Maj. Karolus II, koning van Schotland, Yrland en Engelandt, binnen Scoone 1 Jan. 1651 (Amsterdam: Hugo Allard, 1651). Muller, 2045b.
} 


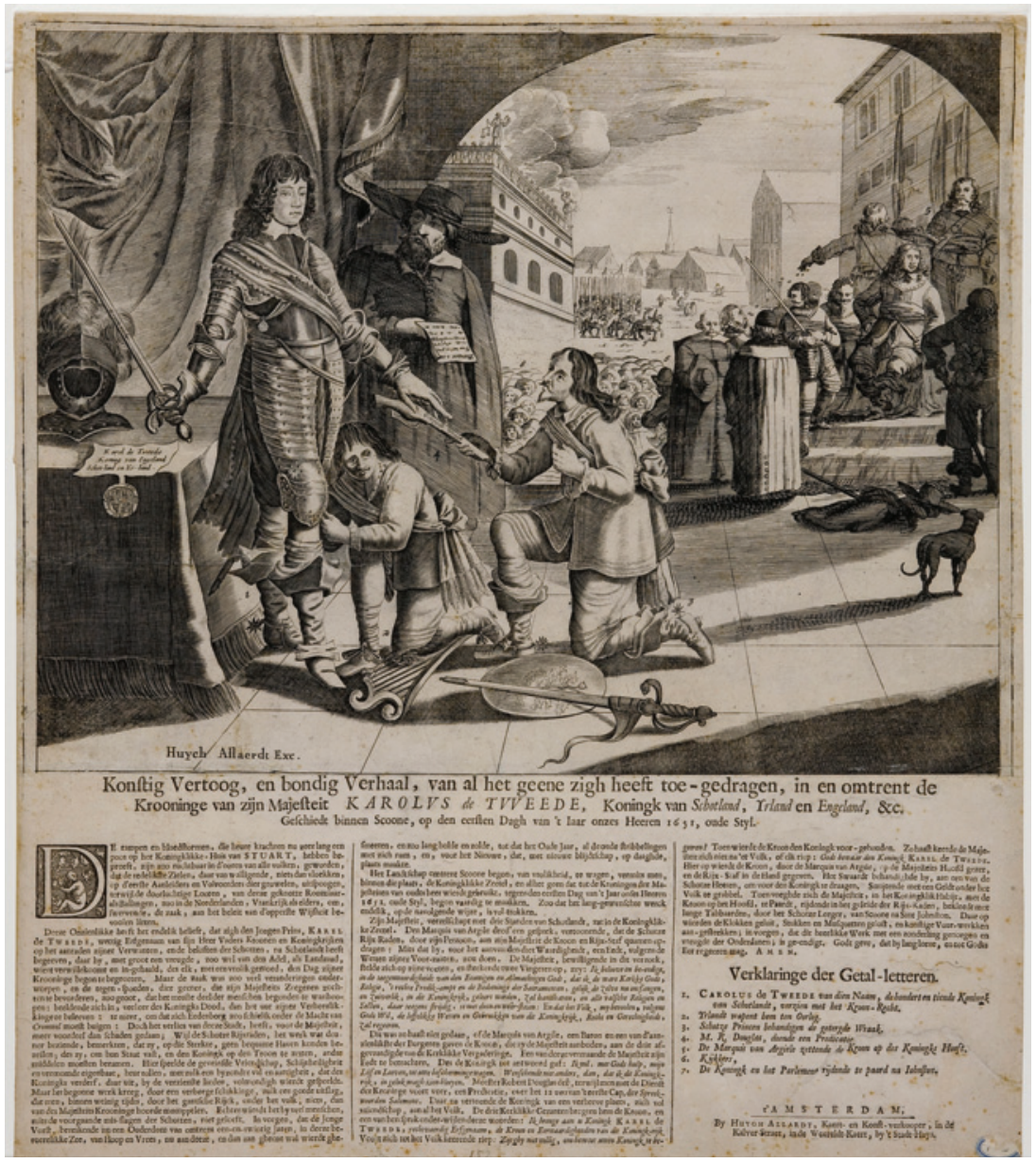

Ill. 2. Artful Relation and Short Story of the Coronation of his Majesty Charles II (Amsterdam: Hugo Allard, 1651). Courtesy of the Atlas van Stolk Museum, Rotterdam (AvS 2158). 
remained without tangible results. When Charles II (now deprived of the support of his brother-in-law) and his Scottish army suffered a disastrous defeat in the Battle of Worcester in 1651, a Stuart revenge had become a distant dream.

The outbreak of the First Anglo-Dutch War in May 1652 opened new perspectives. Initially, little changed: the leading regents of Holland still did not want to commit themselves to the Stuart cause. An alliance with the scattered royalist forces, they believed, would add little to their strength, intensify the unwanted conflict with Parliament and, in addition, strengthen the Orangist party. Well-informed royalists knew that as long as the Anglo-Dutch conflict basically remained a war of trade, it offered little hope for a Stuart Restoration. Edward Hyde, Earl of Clarendon, for instance, claimed to be 'not wise enough to judge which would be best for us, that the Dutch should beat the English or the English the Dutch'. ${ }^{60}$ As it was, a Dutch triumph would only strengthen the position of the royalists' opponents in the Dutch Republic, while an English victory would strengthen their enemies at home. A formal agreement between Charles II and the States General would change that.

When the course of the war proved disastrous for the Dutch, Holland's war policy came under severe pressure, and Orangist opposition in Holland quickly gained in strength. In the summer of 1652, Constantijn Huygens, in a letter to an English royalist exile, Lady Morgan, already hinted crisis might be coming which would stir up the populace against the States of Holland. ${ }^{61}$ In the tumultuous first half of 1653, that crisis culminated. ${ }^{62}$ In February, Grand Pensionary Pauw had sent a letter to Parliament in which he expressed Holland's desire for peace. Unfortunately for Holland, Tromp was routed in the Battle of Portland soon afterwards (28 February-2 March 1653 NS), ${ }^{63}$ and an outright English victory rather than a diplomatic peace was at hand. In the meanwhile, Pauw had died, and Johan de Witt had been appointed as Grand Pensionary. One of his first deeds was a beginner's mistake: he sent another letter to Parliament, which was triumphantly published in England as the Humble Prayer of the States of Holland

\footnotetext{
60 Cited from Geyl, Orange and Stuart, p. 91.

${ }^{61}$ Rowen, John de Witt, 68. The letter to Lady Morgan is published in: Worp, De Briefwisseling van Constantijn Huygens, 5, p. 147.

${ }_{62}$ Israel, Dutch Republic, pp. 713-26.

63 Dutch: 'Driedaagse Zeeslag'.
} 
for Peace on 18 March. ${ }^{64}$ De Witt had humiliated himself without any result. Holland panicked, and royalist writers attempted to capitalize on popular hostility towards the States Party.

The Orangist upsurge of 1652-1653, which culminated in riots in many towns in Holland and Zeeland (including Dordrecht, The Hague, Rotterdam and Middelburg), and even led to a (temporarily) successful rebellion against the magistrate in Enkhuizen, revived Orangist plans for a Dutch-Stuart alliance. Alexander van der Capellen, Lord of Aartsbergen, and Guelders's delegate to the States General, outlined the Orangists' strategy as he pondered the 'difficult' and 'precarious' Anglo-Dutch war in his diary in the summer of 1653:

The opportunity has presented itself, and is still not altogether lost, to stir up dissension, old hatred and fire of internecine war [in England]. The King of Scotland, now fugitive, has had proposed and requested small assistance, to allow his interest to be asserted and defended with the occupation of one or another harbour. The Highlanders in Scotland have offered their harbours and people, with the request of assistance with regard to the supply of weapons, and munitions of war. The Irish have made, and still are making, like offers. Most of our provinces are inclined to accept these offers; old regents and good patriots judge that, by way of support, assistance, and use of the King's name and banner in some of our ships, revolt within the provinces [of England], and desertion of several naval captains with their ships shall be procured. Yet several regents in Holland are not to be moved to adopt this course, fearing that when the King will be restored in England, the young prince of Orange, through his mother born from the same blood, having grown, shall undertake something to their disadvantage; and because of this, they have favoured the cause of Parliament to the war, and have worked against those of the king. Ships and people engaged to the king's service, loaded with munitions of war, and to be sent over, were arrested, and have been made to unload and disperse. And they are rather persisting to the same maxims. ${ }^{65}$

\footnotetext{
${ }^{64}$ Published in Knuttel, 7389-90.
}

${ }^{65}$ Van der Capellen, Gedenkschriften, p. 395. Translated from the original Dutch: ' $D$ 'Occasie is scoon geweest, ende noch niet al verdwenen, om dissentie, oude haet, ende vuyr van inwendighen oorlogh te verwecken. De Koninck van Scotland, nu fugitif wesende, heeft doen voorslaen ende versoeken kleyne assistentie, om syne interesse te mogen doen gelden, ende patrocineeren met occupatie van d'een ofte d'ander haven. De Hoochlanders in Scotland hebben gedaen aenbiedinghe van haere Havens ende volck, met versoeck van assistentie in toevoer van wapenen, ende munitie van Oorloghe. D'Iren hebben gedaen, ende doen noch, gelycke presentatien. Onse meeste Provintien syn daer toe genegen; ende wort by oude Regenten ende goede Patriotten geordeelt, dat, door de wegh van support, assistentie, ende gebruyck van 's Conincx 
A former confidant of Frederick Henry of Orange, Van der Capellen was a prominent Orangist who also belonged to Huygens's circle. ${ }^{66} \mathrm{In}$ collaboration with Huygens, who as secretary to the former princes of Orange was in close contact with the courts of the Princess Royal and the Dowager Princess Amalia, he laboured to persuade the Hollanders that an alliance with the House of Stuart was the only way to win the war. ${ }^{67}$

Propaganda was obviously part of this political campaign. In prose pamphlets, the argument forwarded by Van der Capellen, that such an alliance would cause dissension in the English navy and army, was repeated and developed. ${ }^{68}$ The fact that The Stage of English Miseries is an accurate rendering of the Orangist argument, and actually depicts the offers made by Scotland and Ireland (albeit three years earlier, in 1650 ), strongly suggests that the court was involved in visual propaganda as well-the engraving may well have been reprinted. The Stuart court duly collaborated with the Orangists. On 21 March 1653 (NS), Edward Hyde, one of Charles II's chief advisers, wrote to John Kent, the royalist resident in Venice: 'the Dutch are instructed how necessary it is for them to join with the King, that they may carry on the war against the rebels prosperously' ${ }^{69}$ Once again, the Orange and the Stuart interest overlapped, and again, they attempted to persuade the populace and the regents of Holland to join them. Yet now they aimed

\footnotetext{
naem ende baniere in eenighe van onse Scepen, revolte in Provintien, ende afval van eenighe Sceeps Capiteynen met haer Scepen te wege gebracht sal worden. Edoch eenighe Regenten in Hollant syn niet te bewegen, om dien wegh te willen ingaen, uyt vreese, dat de Coninck herstelt wordende in Engelant, ende den Jongen Prince van Oragnen, uyt 't selfde bloet door syn Moeder gebooren synde, groot geworden synde, iets tot haer naedeel gedaen ende ondernomen sal worden; ende hebben daeromme de saken van het Parlement in Engelandt voor d'Oorloghe gefavoriseert, die van den Coninck tegengegaen, scepen ende volcke, die tot desselfs dienst aengenomen waeren, met munitie van Oorlogh geladen, ende overgesonden souden worden, aengehouden, ende doen ontladen ende verstroeyen, ende continueeren noch al in deselve maximen.'

${ }^{66}$ Worp, De briefwisseling van Constantijn Huygens, 3, p. 105.

${ }^{67}$ Worp, De briefwisseling van Constantijn Huygens, 5, pp. 185-86.

${ }^{68}$ Cf. Knuttel, 7425-26. Anonymous, Hoe veel den Vereenigde Provintien behoort gelegen te zijn, de her-stellinge van den Coninck van Groot-Brittangie. Uyt-gegeven op de tegenwoordige gelegentheyt van Oorlog tusschen hen, en de Engelsche Rebellen (The Hague: Harman Cornelisz. for Samuel Browne, 1653).

${ }_{69}$ Hyde to Joseph Kent, 11/21 March 1653. Cited in Pincus, Protestantism and Patriotism, pp. 108-09.
} 
to change the character of the war from a trade conflict into a religious war waged to avenge the martyr king. ${ }^{70}$

In line with the date of Hyde's letter, the call for a Dutch-Stuart alliance peaked in March 1653. On hearing of the Dutch defeat, Charles wrote to the Dutch ambassador Boreel on 6 March that he was 'heartily sorry' for the Dutch losses and would gladly 'engage his own person' in the war if the States were willing to assign him some ships. ${ }^{71}$ It can hardly be a coincidence that the Dutch translation of a famous piece of Stuart propaganda was published practically simultaneously with Charles's magnanimous offer. Pierre du Moulin's Wraak-geschrey van het Koning-lijke bloed, tot den Hemel, tegen de Engelsche vadermoorders (Cry of the Royal Blood to Heaven, Against the English Patricides, orig. Regii sanguinis clamor ad coelum, 1652) was signed on 5 March $1653 .{ }^{72}$ Printed by Johan van Dalen, who had previously published two Dutch versions of Salmasius's Defensio Regia, the book was dedicated to Charles II, of whom Van Dalen proclaimed himself to be the 'most humble and loyal servant'. In all probability, then, this translation was the result of the Orange-Stuart campaign in Holland. The cry of the royal blood to which the title refers is taken from Psalm 94. According to Du Moulin, Charles I's blood still cried: 'O Lord God, to whom vengeance belongeth; O God, to whom vengeance belongeth, shew thyself'. The book's main concern, like the Psalm's, is the old enigma, why do the wicked prosper? Or, in this case, why do the regicides prosper? Du Moulin, in Van Dalen's translation, addresses the entire Christian world to support the cry of the royal blood, until 'it will draw revenge from heaven', ${ }^{73}$ and show those who now laugh in God's face that wickedness will eventually be punished. In the Dutch

${ }^{70}$ Cf. Knuttel, 7426. Hoe veel den Vereenigde Provintien behoort gelegen te zijn, de her-stellinge van den coninck van Groot-Britangie (Sam. Browne, 1653).

${ }^{71}$ Cited from Israel, The Dutch Republic, p. 720. See also Geyl, Orange and Stuart, pp. 99-100.

${ }_{72}$ Wraak-geschrey van het Koning-lijke bloed, tot den Hemel, tegen de Engelsche vader-moorders (Rotterdam: Johan van Dalen, 1653). Knuttel, 7361. I have used UBL, Thysspfl., 6141. The original, Pierre du Moulin's Regii sanguinis clamor ad coelum adversus paricidas Anglicanos (Den Haag: Adrian Vlacq, 1652) was published on the eve of the Anglo-Dutch war. Thomason 181:E.1396. Pierre or Peter du Moulin the Younger (1601-1684) a Huguenot (like Salmasius) who shared his father's anglophilia, and had an ecclesiastical career in England from 1628 onwards. He also authored Ecclesiae gemitus sub anabaptistica tyrannide (1649).

${ }^{73}$ Orig. 'tot dat het de wraak uyt den Hemel trekt'. Knuttel, 7361. Wraak-geschrey van het Koning-lijke bloed, 74. 
Republic in 1653, there could be no mistake about the implications of this argument for the war of trade at hand.

Topical poetry embraced the sentiment that the war was about avenging the martyr king as much as it was about trade. Time and time again Dutch poets expressed the royalist view that the war was a war against regicides rather than a war against economic competitors. Even some passages in Huygens's Hofwyck, which was published in 1653 and is usually presumed to be devoid of political allusions, had severe topical overtones. When the speaker in Huygens's poem addresses God (1l. 1235-38), the language becomes reminiscent of the royalist rhetoric of revenge such as that of Du Moulin, and specifically that of the iconography of The Stage of English Miseries: ${ }^{74}$

Let your provoked revenge be satisfied

By the downfall of our neighbouring people

Where your holy inheritance, your Church

Now lies smothered and drowned in royal blood [...]

Huygens's use of the term 'provoked revenge' and his equating the royal cause with a divine cause in the midst of the Orange-Stuart campaign of 1653 left little doubts about his position. Significantly, the war and regicide penetrate even the tranquillity of Huygens's estate.

But whereas Huygens's loyalty to the Houses of Orange and Stuart was well-known, others joining the royalist choir in March 1653 had rather different credentials. As in 1650, Jan Vos contributed to the Stuart cause by way of an elaborate poem of 876 lines with marked Senecan elements, the Zee-Krygh (Naval War), which was also published in the spring of $1653 .{ }^{75}$ At the beginning of this poem, Vos states that although Parliament started the war because they envied

${ }^{74}$ Translated from the original Dutch: 'Laet dijn geterghde wraeck versaedt zijn in 't verderf / Van ons gebuerigh volck, daer nu dijn heiligh erf, / Dijn' kercke, light gesmoort en in haer bloed versopen, / Haer Conincklicke bloed, en buijten hulp en hopen, / En buijten trouw en troost voor eewigh schijnt ontdaen, / 'Ten zij ghij met de boos' eens in 'tgericht wilt gaen.'

${ }^{75}$ Jan Vos, Zee-krygh tusschen De Staaten der Vrye Neederlanden, En het Parlement van Engelandt, Vos, Alle de gedichten I (Amsterdam: Jacob Lescaille, 1662), pp. 299-332. In 1653 the poem was published as a separate pamphlet (Knuttel, 7322) and in the second part of the poetry collection Verscheyde Nederduytsche gedichten (Amsterdam: L. Spillebout, 1653). Translated from the original Dutch: '[...] quam voor't ledekant van zijn gevluchte Zoon: / Op, sprak hy, nu is't tijdt van winnen, en van wreeken. / De weêrwraak, om't verlies van zetel, staf en Kroon, / Is Goddelijk: want Godt heeft $\mathrm{u}$ tot Vorst geschaapen / Het recht der Koningen bewaart men door het waapen. / De Leeuw van't vrye Landt zal u het heirspoor baanen'. 
the Republic's wealth, the ultimate cause of the war was the execution of the king. He describes how Charles I's execution by 'de bijl der dolle Londenaaren' ('the axe of raging Londoners') caused Pluto to convene the Hellish Hordes in the underworld. There it is decided that Revenge should visit Parliament to cause war with the Dutch Republic, because the hellish reign in England must be buttressed by Dutch wealth. The Republic on the other hand will help to restore the rightful dynasty of the murdered king. This is revealed to Charles II by the ghost of his father, which

[...] came before the bedstead of his exiled son

Rise, he spoke, the time has come to win and to revenge.

Counter-revenge, for the loss of sceptre, throne and crown,

Is divine, for God has created you as a Prince

And the right of Kings is guarded by weaponry.

The Lion of the free Country shall pave your way. ${ }^{76}$

Paving the way for Charles's revenge, the Dutch lion is here presented as the guardian of the divine right of kings; the Dutch Republic and Charles II share a similar cause. Like Du Moulin's Cry of the Royal Blood, then, Vos's Naval War propagates an alliance between the Dutch Republic and the exiled Charles II, echoing the language of both the vengeful ghosts in the pamphlet literature and his own Britain to Europe.

When the Naval War appeared in March 1653, it was exceptional in two respects. In the first place, with Jacob Westerbaen's Hollands vloeck aen het parlementsche Engeland (Holland's Curse to the Parliamentary English, 1653), ${ }^{77}$ it was one of the longest topical poems on the war. A far more interesting and far more exceptional feature of the poem, however, is the fact that it was preceded by a dedication to Vos's patron Joan Huydecoper, one of the most powerful men in Amsterdam. Considering the poem's advocacy of the Stuart cause, and its affinity to royalist propaganda, the fact that Huydecoper was prepared to have his name attached to it was an important political message. It indicated that within the ruling elite of Amsterdam there was a movement towards an alliance between the Dutch Republic and

\footnotetext{
${ }^{76}$ Vos, 'Zee-Krygh', p. 329.

$77 \mathrm{~J}$. Westerbaen, Hollands vloeck aen het parlementsche Engeland op het stuck van de zee-slagh gevallen tusschen de ammiraelen Tromp en Blaeck [...] op den lesten febr. ende den 1. en 2. maert, 1653. UBL Thyspfl. 6168.
} 
the exiled Charles II, an inclination towards a hardening of the war, and a move away from Holland's official policy.

The republication and performance of Dullaert's Karel Stuart can also be interpreted as a sign of Amsterdam's attitude towards the Stuart alliance. ${ }^{78}$ The martyr play written shortly after the execution of the king four years earlier went through no less than ten consecutive performances in the Amsterdam theatre, the theatrical heart of the Dutch Republic, in March 1653. ${ }^{79}$ As in the case of Du Moulin's Cry of the Royal Blood, the political implication of such performances could not have escaped the audience: the Dutch were not fighting a war against economic competitors, but against godless regicides. In 1652-1653, the imagery developed in the wake of the regicide had only gained in political urgency.

\section{Conclusion}

Having detailed the political impact of the royalist rhetoric of revenge, its main forms, and its poignancy in 1649-1650 and 1653, it is now time to consider its cultural significance. Dutch literary history has usually considered topical poetry and topical drama to be somehow separated from mainstream culture, 'incidental trifles' which should at best be mentioned in passing. ${ }^{80}$ From the perspective of contemporaries, however, quite the opposite is true: for them, current events occupied centre stage, and the debates these inspired coloured their experience of literature. As the republication of Palamedes in 1652 indicates, literary genres such as Senecan revenge tragedy could suddenly gain in urgency as the horrors of civil war and regicide posed political and religious dilemmas.

Plays like Jan Bara's Restored Prince or Lodewijk Meyer's Royal Bride openly participated in the political discourse surrounding the English revolution. And, indeed, the topical significance of the generic elements such as the vengeful ghost or Senecan horror also affected the interpretation of other revenge tragedies that were not explicitly

\footnotetext{
${ }^{78}$ De Jong, 'Joan Dullaarts visie op de terechtstelling van Karel Stuart', p. 163 mentions the Three Days' Battle as a possible reason for the consecutive performances in March.

79 See Oey-de Vita and Geesink, Academie en Schouwburg, pp. 121-22 and 159.

${ }^{80}$ Cf. Sellin, 'Royalist Propaganda', pp. 259-60.
} 
topical. Hamlet, for instance, or Jan Vos's Shakespeare adaptation Aran en Titus (1638) also tended to equate the revenge of the rightful heir to the throne with divine vengeance. And what are we to make of Lambert van den Bosch's translation of Seneca's Agamemnon (1661)? Published shortly after the Restoration, this play, written by the staunch royalist Van den Bosch, also features the ghost of a father who urges his son to revenge, which surely evoked the tragedy of Charles I and the successful revenge of the modern Orestes, Charles II.

Dutch playwrights like Dullaert frequently fell back on examples dating from the Truce Conflicts not only because they provided handsome rhetorical and poetical models but also because the drama of those days constituted a frame of reference helping Remonstrant poets to interpret the unprecedented upheavals in England. The literary and theatrical parallels that were drawn between the executions of Van Oldenbarnevelt and Charles I, then, signify that a literary form such as Senecan tragedy was not only a propagandistic tool but also an interpretative framework. Whether the former or the latter function dominates in the texts discussed above is often difficult to say, but doubtless, political discourse was shaped to a considerable extent by cultural memory and pre-existing literary forms.

The frequent use of theatrical metaphors in literary texts about the regicide also suggests that the drama played a substantial part in shaping people's views of the regicide. The notion of the theatrum mundi, the assimilation of history and theatre, seems to have contributed to the poetic appeal of the Stuart cause. This was surely stimulated by the performative quality of Charles I's execution. Many scholars writing on the subject cite Andrew Marvell's Horation Ode upon Cromwell's Return from Ireland (1650), in which Charles is styled 'the Royal Actor', who nobly underwent his fate: 'He nothing common did or mean/ Upon that memorable scene'. It is less well-known that the comparison between the execution and a tragedy was a commonplace that was also frequently employed by commentators in the Dutch Republic. ${ }^{81}$ The Dordrecht poet Roemer van Wesel ('Romane'), for example, composed a poem with the telling title De lijdende christus, treur-spel, Vertoont tot Londen, den 9en Febr. 1649 (The Suffering Christ, Tragedy

${ }^{81}$ Cf. also title of the well-known description of the execution of Charles I, Tragicum Theatrum actorum, \& casuum tragicorum Londini publice celebratorum (Amsterdam: Jodocus Jansonius, 1649). 
Performed in London, on 9 February 1649, w. 1649) in which Charles performs the main part in a Passion play. ${ }^{82}$ We may consider the idea that the theatrical metaphor is not a metaphor at all, that Charles I was indeed perceived as an actor playing his role in a divine Passion play in a very real sense. And that his son, by extension, was the protagonist in a divine revenge tragedy. The Dutch confidence in his revenge then boils down to Horatio's words in Hamlet: 'Heaven will direct it' (Hamlet, I.IV.68).

Eventually, heaven would. In a way, the (almost) bloodless restoration of Charles II, in 1660, confirmed the moral of revenge tragedy's happy ending. Indeed, Charles's procession through the Dutch Republic was all but a dramatic event, as the re-established king played his triumphant part to the cheers of a Dutch audience that had been enthused about the English monarch by a decade of royalist literature. The Dutch Republic, which had enjoyed the Senecan images of Charles II's retribution for such a long period, now became the real stage of his return to power and grace. This outcome, conforming as it did to a cherished aesthetic form, obviously confirmed the belief in a just God and the Divine Right of Kings. Perhaps somewhat less obviously, it also encouraged the belief in the ultimate reality of theatre.

${ }^{82}$ R. van Wesel, 'De lijdende christus, treur-spel, Vertoont tot Londen, den 9en Febr. 1649', in Bloemkrans der verscheyde gedichten (Amsterdam: L. Spillebout, 1659), pp. 294-95. 



\section{'A VILE AND SCANDALOUS DITTY': POPULAR SONG AND PUBLIC OPINION IN A SEVENTEENTH-CENTURY DUTCH VILLAGE CONFLICT}

Joke Spaans

A popular song was heard in the taverns in and around Alphen during the Hazerswoude Fair in October 1686. Carpenters at work at the Gouda Lock, halfway between Alphen and Hazerswoude, sang it as a shanty. Its lyrics, set to a catchy tune, commented upon a local conflict. Indicated by nicknames and oblique references, impossible for us to decode, but undoubtedly easily identifiable to singers and listeners, local worthies were subjected to sharp criticism. According to the song, seventeen couplets long, those responsible for the church, and from whom integrity was most required, had seriously disturbed the peace in Alphen. It purported that one of them, called Oudshoorn, had been infamously banished, that among them was a brewer who had left nearby Leiden in shame after a bankruptcy, and that others were publicly known as fraudulent, quarrelsome, drunk and disorderly. The venom of the text was in the last two couplets. Here a Justice Roosenboom, probably Huybert Roosenboom, a member of the Supreme Court of Holland and Zeeland, ${ }^{1}$ was accused of rousing the rabble that had lynched Johan and Cornelis de Witt-the Grand Pensionary of Holland and his brother, a naval hero-at the square called the Green Sward in The Hague, in 1672. These last couplets in particular seriously offended the authorities, and earned our song the epithet 'a vile and scandalous ditty'. ${ }^{2}$

The song belongs to a broad and evanescent genre of popular verse that accompanied sensational events in the early modern period. Rhymed couplets adorned pamphlets, prints and commemorative

\footnotetext{
${ }^{1}$ Hora Siccama, Aantekeningen en verbeteringen op het [...] register op de journalen van Constantijn Huygens den zoon, pp. 592-94.

${ }^{2}$ For the text see the Appendix. It is preserved in manuscript in the Criminal Papers of the Provincial Court of Justice of Holland, NA, Archive Hof van Holland, shelf no. 5353.13 (1689).
} 
medals, varying in quality from formal neo-Latin verse to crabbed doggerel. Only the best or the most appreciated were commercially interesting and were gathered in printed albums that were, like pamphlets and medals, kept as souvenirs and collected by posterity. Others, like our ditty, circulated in manuscript or even oral form. Some of these have survived because they ended up in scrapbooks or, as in this case, were copied into official documents, but most have been lost. ${ }^{3}$ Producing, copying, reading and singing these texts must have been an immensely popular pastime. The scattered remains of this form of cultural expression show that information about current events could be plentiful, and reached all levels of society.

But did this amount to what we call public opinion? If texts critical of the powers that be are produced and circulated, does that always count as public opinion? How did political songs like this one function in early modern society? Before addressing these wider questions, let us first take a look at the context in which our vile and scandalous ditty was made and sung and at the effect it had on the local conflict in Alphen.

\section{Alphen as an industrial zone, area of CONFlict, AND THEATRE OF WAR}

There is ample evidence that something was very much amiss in Alphen aan den Rijn in the 1680s, and that the church was at the centre of the disturbance. From 1682 to 1687 the local minister was involved in an ugly conflict with his congregation. This in itself was nothing unusual. Controversial ministers abound in the minutes of consistories, classes and synods. This particular local conflict, however, spun wildly out of hand, and eventually led to a standoff between the two highest courts of law in the province of Holland. Stadtholder-King William III himself stepped in to mediate. Apparently, these local troubles in Alphen touched a sensitive nerve in the relations between church and state in seventeenth-century Holland.

Not much is known about the church history of Alphen in the seventeenth century, but what we do know is decidedly lively. ${ }^{4}$ The village

\footnotetext{
${ }^{3}$ Cf. Bellany and McRae (ed.), 'Early Stuart Libels'; Spaans, 'Pen als wapen?'

${ }^{4}$ Local church histories in Regt, Gedenkboek ter gelegenheid van het 350-jarig bestaan der Nederlands Hervormde gemeente te Alphen aan den Rijn, and Baudet, " "In beweging bewogen."'
} 
was strategically located in the heart of South Holland, at the intersection of the Old Rhine with the Gouwe from the south and the Heimans canal to the north. These waterways form a crossroads between Amsterdam, Rotterdam, Leiden, The Hague and Utrecht, and were plied by regular towboat services. Here too the routes of stagecoaches to and from these centres converged, and postal couriers, serving the Holland cities and connecting them to their European-wide hinterlands, had their distribution centre here. Its location made Alphen a flourishing market town, especially for meat, fish and dairy produce. Sawmills, shipbuilding, tile and brickworks, and the production of clay pipes, profiting from the river traffic and an abundant supply of energy from the ever-present wind and the extensive peat-producing bogs to the south and east, added industrial bustle. It boasted a French school and an orphanage. Alphen thus fell into a middle category between mere village and city. All this made it a pleasant place to live, for the rural gentry in the three manor houses within Alphen's boundaries and for the local notables in their comfortable homes along its welllaid out main streets and waterfronts. Alphen has even been graced by a local history extolling its beauty, wealth and ancestry, of a kind usually reserved for cities. ${ }^{5}$

The church of Alphen appointed only young, but learned and wellconnected ministers with some previous pastoral experience. Usually they left after a few years for cities, the end-stations of successful ecclesiastical careers. Only small towns and the larger and more prosperous villages could afford this class of ministers. ${ }^{6}$ The first half of the seventeenth century saw Alphen and its church flourish. A fire that destroyed most of the village and the church in 1619 could not hamper its growth. Everything was quickly rebuilt. The Reformed congregation grew from 276 full members in 1619 to over 500 around the middle of the century. ${ }^{7}$ Whether these numbers reflect demographic growth of the community as a whole or rather protestantization is unclear.

\footnotetext{
${ }^{5}$ Plemper, Beschryving van de heerlykheid en het dorp Alphen aan den Ryn. A more concise near-contemporary description of Rijnland and Alphen in Wagenaar, Hedendaagsche historie, of tegenwoordige staat van alle volkeren (= Tegenwoordige staat), vol. 16 (1746). More recent: Dinkelaar, De Wilde, and Van Zwieten, Volk op viersprong.

6 Van Rooden, 'Van geestelijke stand naar beroepsgroep'.

7 Regt, Gedenkboek, pp. 41-48; Streekarchief Rijnlands Midden (SARM), Archive Nederlands Hervormde Gemeente (= NHG), shelf nos. 9, and 156.
} 
The original parish comprised both Alphen proper and the nearby village of Oudshoorn, but these villages belonged to two different ambachtsheren. ${ }^{8}$ These either had to concur or take turns in the appointment of ministers to the shared parish church of Alphen. Apparently the two gentlemen did not see eye to eye, and in 1661 the ambachtsheer of Oudshoorn, Cornelis de Vlaminck, made Oudshoorn an independent parish. In this venture De Vlaminck gave full rein to personal vanity, and the church he built, mainly from his own purse, had a reputation of extraordinary beauty. Of course he appointed its ministers. Simple rivalry may have been an important factor in this dispute. De Vlaminck was rich and, as former burgomaster of Amsterdam, extremely well connected. He appears to have been more successful in stimulating prosperity and obtaining privileges for his village than his neighbour in Alphen. Oudshoorn was only half the size of Alphen, yet it had almost as many mills, wharves and factories. ${ }^{9}$ The towbarges and mail-couriers stopped in Oudshoorn, not in Alphen. The fact that the ambachtsheren of Alphen were Catholic, and thus subject to restrictions in the execution of public office, compounded these economic and ecclesiastical rivalries.

The secession of Oudshoorn in turn seems to have aroused local pride in the Reformed congregation of Alphen. As if to hold their own against the showy new church of Oudshoorn, newly admitted members to the Alphen congregation started to donate gifts to their own house of worship. In 1662 the church received a panel painted with the calligraphed text of the Reformed Confession of Faith, in 1666 a set of copper candlesticks, in 1689 an ornamental copper arch to adorn the entrance to the enclosed space around the pulpit and the baptismal font, in 1722 silver plates and cups for the celebration of the Lord's Supper and in 1744 an ornament for the pulpit. ${ }^{10}$

\footnotetext{
${ }^{8}$ An ambachtsheer was the highest authority in a village with its outlying hamlets. In the seventeenth century the office, originally a noble fief, could be inherited or bought, and its main attraction was in the rights of patronage it brought the bearer. Appointments to local public office had to be approved by the ambachtsheer. Ambachtsheren came from the gentry or urban patriciate. Some, like Cornelis de Vlaminck, added the name of 'their' village to their family name in imitation of noble titles.

${ }^{9}$ Alphen boasted 136 houses in 1632 and 315 in 1732, Oudshoorn 64 and 183 respectively, but both were almost equally 'industrialized', Tegenwoordige staat, pp. 251-52, 260.

${ }_{10}$ Regt, Gedenkboek, pp. 24-26, Tegenwoordige staat, p. 254.
} 
Even after the secession of 1661, De Vlaminck kept meddling in the church affairs of Alphen. In 1656 Alphen had been allowed a second minister, as an assistant and designated successor to the incumbent. At the death of the senior minister and the succession of the assistant in 1670, the consistory of Alphen tried to get a new assistant minister, arguing that the workload was too heavy for one man alone. De Vlaminck protested before the States of Holland that Alphen could very well be served by one man, especially now that the congregation had been split. The States of Holland agreed. The consistory of Alphen, with the full support of its own ambachtsheer and burgomasters, then decided to raise the salary of their pastor with an extra allowance from the village funds, as if to emphasize the standing of Alphen, economically and socially a notch above that of the surrounding villages, and especially its obnoxious neighbour Oudshoorn. The standing of the local church was very much an expression of local pride.

An epidemic in 1669 and the war of 1672-1678 dealt Alphen and its church two further blows. Nothing specific is known about the epidemic. ${ }^{11}$ In 1672 Alphen found itself just behind the weakest spot in the so-called Water Line, the belt of land that could be inundated on the approach of enemies from the east and which, in combination with the natural obstacles of the great rivers and strategically placed man-made fortifications, made up the defensive ring around the core of the powerful province of Holland. French armies breached that weak spot, pillaging and burning nearby Bodegraven and Zwammerdam and Oudewater further to the south, ${ }^{12}$ ravaging the surrounding countryside and causing considerable loss of life. The French armies were stopped at the Gouda Lock, at the confluence of Gouwe and Oude Rijn, a little east of Alphen.

Alphen itself was spared. In fact, William III, just elevated to the stadtholdership to beat back the invaders, made it his base of operations. The delegates of the States of Holland who used to follow the army in its campaigns as a War Council, advising the stadtholder in his capacity as Captain-General, stayed here. A captain of the States army, who had prematurely abandoned the fort he commanded before the approach of the enemy, was publicly executed in Alphen. Many of

\footnotetext{
${ }^{11}$ No mention of an epidemic in this year in the 'Lijst van 585 publicaties [...] over of n.a.v. epidemieën en plagen, gesorteerd op jaar' <http://www./rampenpublicaties.nl>.

${ }^{12}$ Cf. Haks, 'De Franse tirannie'.
} 
its residents, however, fled the threat of war. Despite a rousing speech from the stadtholder on New Year's Day 1673, in which he called upon these fugitives to return and offered them his protection, life was seriously disrupted. In 1675 the congregation had fallen to 300 members, a loss of around 200 from only five years earlier. ${ }^{13}$ Alphen was anything but the rural idyll its lush surroundings and prosperity might suggest.

\section{A CHURCH DIVIDED}

The turbulent period following the Year of Disaster 1672 apparently left Alphen deeply divided. The precise nature of the division is hard to determine. These years were, however, marked by intense polarization between adherents of the House of Orange and those regents who preferred True Liberty: a stadtholderless regime that allowed them to divide political power and the more lucrative offices among themselves. ${ }^{14}$ The local notables of Alphen had ties to the regents of the larger cities, and this made the prosperous village vulnerable to urbanstyle factionalism. The Catholic ambachtsheren of Alphen were traditionally Orangists. Most prominent Catholics considered the House of Orange the protector of their interests against the privileged Reformed elite. The former ambachtsheer of Alphen, the Catholic Hendrik Stevin, had even been a close associate of Prince Maurits. His successor Jacob van der Meer was again a Catholic. The local sheriff, Adriaan Roosenboom, was a member of a family that provided many high-ranking legal professionals, one of whom, Frederick Roosenboom, married a granddaughter of Simon Stevin. Both he and his elder brother, Justice Huybert Roosenboom, were close confidants of William III. All over the Republic, Orangists jostled to gain the upper hand over the previously dominant adherents of True Liberty, and this seems also to have been the case in Alphen.

The church became the principal battlefield. After 1672 the procedures to elect new ministers for Alphen were heavily contested between candidates who had studied in Leiden and Utrecht respectively. At this time these theological faculties were dominated by rival schoolsLeiden by the followers of Johannes Coccejus, who were often con-

\footnotetext{
13 Van Es, Limes en linie, pp. 50-62.

14 Israel, The Dutch Republic, pp. 807-15.
} 
nected to regent circles committed to True Liberty, and Utrecht by the followers of Gisbertus Voetius, who tended to be staunch Orangists. After an exceptionally long vacancy, marked by wrangling in the consistory and in the magistracy, one of the many Roosenbooms with ties to Alphen, ambachtsheer Van der Meer, and other, unnamed, patrons secured the appointment of the Voetian Adriaan Bouman in Alphen in 1682. Within months the newly elected minister had antagonized a large part of his congregation, among them a number of (supposedly Coccejan and non-Orangist) church wardens, elders and deacons.

Bouman was a quarrelsome man, who spread malicious gossip about church members and fellow ministers. Moreover, he shirked the duties the Alphen congregation expected from its ministers, and for which the village paid him an extra allowance. The most important of these duties was preaching on Wednesdays as well as on Sundays and official holidays-unusual in villages, but customary in cities. In this respect too, Alphen's local pride manifested itself. Offended parishioners appealed to the classis, ${ }^{15}$ and eventually to the Provincial Court of Justice to investigate whether Bouman had committed fraud in registering his letter of appointment, which specified his workload, in the registers of the Alphen consistory. Bouman and his local patrons, however, did everything they could to obstruct this investigation. In the summer of 1685 adherents of the minister harassed a committee from the classis, sent to Alphen to investigate. They gate-crashed the meeting of the committee in the church, forced its secretary to write a report that exonerated the minister, and threatened bodily harm. After the mob had finally released the investigators, it retired to Bouman's house, where the fake 'report' of the meeting was read under raucous merriment and the minister treated everybody to wine.

Despite all this, the classis found confirmation of its suspicion of fraud. It was powerless, however, against the injunctions of the Provincial Court of Justice, which denied the classis jurisdiction over the case. The classis only had the right to adjudicate appeals against decisions of a consistory, and in Alphen the consistory, itself party to the conflict, deliberately left the case undecided. Discontent with the minister smouldered on in Alphen. On 7 October 1686, during the annual

${ }_{15}$ The classis held the middle position between the local consistory and the Provincial Synod in the government of the Reformed Church. Classes discussed and decided matters of supralocal importance, oversaw the appointment of ministers and also formed a court of appeal on the decisions of consistories. 
fair of nearby Hazerswoude, our 'vile and scandalous ditty' was sung in an Alphen tavern. Among the singers were some of the instigators of the mayhem in the church of Alphen in the summer of the previous year. Early in November four of the singers were arrested, lifted from their beds in the middle of the night. They were put in custody in The Hague, to be released on bail after a month. During their incarceration the Reverend Bouman was also cited before the Provincial Court.

Factionalism now reached dangerous levels in Alphen. Insults flew thick and fast. People exhorted their children to harass those of the other party by following them in the streets and taunting them with satirical songs. By the end of November the Provincial Court issued an order to end all public disturbances, signed by its president, stadtholder William III himself. The case against Bouman dragged on all through the first half of 1687 . It proved very difficult to reconstruct exactly what had been agreed between minister and patrons about the Wednesday sermons. All this was meticulously analysed in the final indictment, which contained no less than 1348 articles, and in which Bouman was found guilty of fraud with his letter of appointment, and of incitement to riot and sedition. The Attorney General stated that Bouman's local patrons had boasted that they would 'wash the dirty pig', i.e. keep his reputation clean, despite the fraud he had committed. The metaphor earned the conflict the name of the Alphen Pig War. The Attorney General demanded suspension from office, exclusion from any public office or service in Holland, Zeeland and West-Friesland for life, a heavy fine and payment of all the legal costs incurred in his case. In view of the fact that a minister had committed all these heinous crimes, the Attorney General considered even corporal punishment appropriate. ${ }^{16}$

A final verdict was never struck, however. Pending this trial before the Provincial Court, the plaintiffs against Bouman appealed to the classis to have him suspended from office. Bouman and the Alphen magistrate again successfully mounted a counter-offensive. Now they managed to get the Supreme Court of Holland and Zeeland to proscribe any action of the classis in the case of Alphen, again denying church members the right to appeal to the classis in a case that had

${ }^{16}$ Spaans, 'The Alphen Pig War', pp. 333-41, for the indictment see Criminal Papers of the Provincial Court of Justice of Holland, NA, Archive Hof van Holland, shelf nr. 5349.24 (1688). 
not first been decided by the consistory. The Provincial Court of Justice denied the Supreme Court jurisdiction in this case, which was taken by the Supreme Court as a challenge to its authority. The two Justices of the Supreme Court who had been assigned to this case, both from Amsterdam, invoked the support of the Amsterdam magistrate, which in turn accused the Attorney General and the Provincial Court of Justice of obstruction. This led to an unprecedented clash between the two Courts. On 17 June 1687 the States of Holland formulated a resolution, which in fact was an order of the Prince of Orange, pronouncing a mistrial and demanding the destruction of all files pertaining to the case. ${ }^{17}$

Despite the strong language of the Attorney General, Adriaan Bouman would remain in office in Alphen until his death. As the charges had been dropped and the entire affair had been hushed up at the command of the stadtholder, his position in Alphen was safe. Both the malcontent parishioners, who had tried so hard to have him removed, and his patrons, for whom he must have become something of a liability, had to accept his continuation in office-and moreover all parties were forbidden to divulge the heart of the matter: the fraud committed by the minister under the protection of local patrons. Life went on as if nothing had happened. In the classis Bouman retained the honour due to his rank as minister of Alphen. He also held a doctorate in medicine, which entitled him to loftier honorific titles than the other village ministers, and these were duly used. The South-Holland synod made him correspondent for the Synod of Groningen, an honourable commission that was only entrusted to capable men. ${ }^{18} \mathrm{He}$ was, however, never called to a more prestigious pulpit. For Bouman Alphen was not the stepping stone from village to city it had been for many of his predecessors and successors.

${ }^{17}$ Hollandsche Mercurius (1687), pp. 162-71, Copie Missive en Resolutien van de Ed. Groot Moog. de Heere Staten van Holland ende West-Vriesland, aen den President en Raden van den Hoogen Raed, in Holland afgesonden, Anno 1687, Knuttel 12646, orig. in NA, Archives Hof van Holland, inv. nr 394, f. $224^{\mathrm{r}}-226^{\mathrm{r}}$.

${ }_{18}$ NA, Archive Classis Woerden and Overrijnland, inv. nr 10, p. 235 (June 24, 1687; SARM, Archives Notaries Alphen, inv. nr 176, unpaginated (May 3, 1688). Bouman was formally addressed as 'Eerwaarde godzalige en Hooggeleerde Heer'. 


\section{OUR VILE AND SCANDALOUS DITTY AS AN EXPRESSION OF PUBLIC OPINION?}

The ditty that was sung in Alphen at the time of the Hazerswoude Fair in October 1686 pilloried the Orangist patrons of the Voetian minister. Those patrons were located not only in the local Voetiandominated consistory, but also in wider networks of power. In the infamously banished Oudshoorn, mentioned in the fourth stanza, we can discern the meddlesome ambachtsheer of the rival neighbouring village, Cornelis de Vlaminck van Oudshoorn. In 1682 he had been excluded from the select company of those eligible for the office of burgomaster in Amsterdam, as part of the political power struggles in that city-a situation that might well be compared to banishment. ${ }^{19}$ By 1686 De Vlaminck was safely dead. The other persons indicated in the ditty are all disguised by nicknames, except for Justice Roosenboom of the Supreme Court, close to the stadtholder himself, who was alive-and not amused. The Orangist political network that had come to power in Alphen after the restoration of the stadtholdership extended all the way to the Court.

The ditty undeniably expresses opinion, and it was sung in public. But does that make it an expression of public opinion? Scholarly views on public opinion in the early modern period diverge. It is obvious that, from the invention of the printing press, political and religious crises were often accompanied by the production of popular literature and print. Production of these texts peaked during crises. This feeds the conviction, fostered over the last few decades, that these changes were the subject of lively debate that merits the designation 'public opinion'-not only in the eighteenth century, as Habermas argued, but also in previous centuries. Public opinion is not always clearly defined. Generally it is taken to be the reflection of current affairs in popular literature, aimed at a wide audience-wider than those with reading skills. After all, pamphlets and broadsides were also read out to illiterates, and songs, sermons, theatre and popular prints needed no such skills. Through the attention given to current affairs in popular media, this general public is held to have exerted pressure on

\footnotetext{
${ }_{19}$ Elias, Geschiedenis van het Amsterdamse regentenpatriciaat, pp. 173-87; idem, De vroedschap van Amsterdam, pp. 505-07.
} 
governments that could not ignore public opinion. Public opinion was thus a catalyst of change. ${ }^{20}$

This may be an anachronistic interpretation of the media coverage of early modern crises and controversies. It is especially hard to measure its impact and influence. The authorities of state and church regulated the printing press, the theatre and the pulpits. Popular street songs and pasquinades not disseminated in print escaped regulation, being too elusive, but little of that kind of popular expression has been preserved or studied, and its impact is therefore hard to measure. ${ }^{21}$ Much published topical material was anecdotal, spreading tales about remarkable incidents, without interpreting them as part of wider political or social developments. This made them entertainment rather than argumentation intended to form opinions. Much was propaganda, produced by authors close to the authorities and reflecting their views. It has been argued that in France, until the second phase of the Jansenist controversies after 1713, the public sphere was in fact the Court; all else was irrelevant. ${ }^{22}$ In England, where the satirical press was well developed in the late seventeenth and early eighteenth centuries, pamphlets and prints critical of the authorities were often tolerated-because nobody took them seriously. They were considered popular entertainment, lacking the authority that was precisely the monopoly of state and church, and often ill-informed and biased as well. ${ }^{23}$ 'Opinion' was a word with strongly negative connotations.

The commentaries on current events in early modern popular media do reflect attitudes and aspirations that were-sometimes passionately-embraced by parts of the population, but most are hypes or otherwise marginal. Systematic research into Dutch pamphlet literature, political prints and songs has only recently commenced, but several studies draw attention to the fact that publications often appeared at the point when the problem had already been resolved, so that they

${ }^{20}$ Van Dixhoorn, Lustige geesten; Duccini, Faire voir, faire croire; Harline, Pamphlets, Printing, and Political Culture; Pollmann and Spicer, Public Opinion and Changing Identities, 'Introduction'.

${ }_{21}$ Weekhout, Boekencensuur in de Noordelijke Nederlanden. Cf. also the cautions expressed in Bloemendal, 'Receptions and Impact' and Cust, 'News and Politics', pp. 66-69.

${ }_{22}$ Farge, Dire et mal dire, pp. 25-41; Arblaster, 'Private Profit, Public Utility and Secrets of State'.

${ }_{23}$ Atherton, Political Prints in the Age of Hogarth, pp. 68-82; De Bruin, Geheimhouding en verraad, pp. 402-35. 
only confirm, and often justify, the outcome. ${ }^{24}$ Real discussion of current issues, therefore, was often lacking in substance. ${ }^{25}$ The delay in publications on current issues may be due to the opportunism of publishers, or to the effects of censorship. Serious criticism of the officers of state or church was considered an infraction of their personal honour and authority, and incurred heavy penalties for slander or even sedition. Opinions voiced by whatever public were thus divided into a large majority of either harmlessly superficial or conformist ones that could safely be tolerated, and a few harmful, slanderous ones that should be silenced, and often were. Either way opinion did not discuss issues of public interest, and did not have much impact on governmental policy or society at large.

Back to our ditty: was this an expression of public opinion? At first sight it is. It unmasked those that were responsible for the church, for upholding religious authority, as conceited and greedy. It connects them to political crime at the highest level, first by asserting that they belonged to a network led by Justice Roosenboom, and secondly by insinuating that this man had incited the lynching of the brothers De Witt in 1672. Suspicions about the involvement of William III in the lynching of his political opponents had existed from the beginning, but it was highly unwise to utter them in public. In a tragedy about the murder of the brothers De Witt the poet Joachim Oudaan accused the stadtholder and four or five Justices to have plotted the lynching in a secret conspiracy. He never published the text, and on his deathbed ordered his heirs to destroy it. They did not, but, recognizing the sensitivity of the material, the play was not published until 1712, twenty years after the poet had died, and even then under a false imprint. ${ }^{26}$ Accusing Justice Roosenboom of playing a part in this conspiracy in the taverns and on the streets of Alphen, in the context of a local conflict, must have aimed at public denunciation of the other members of the Orangist faction, the patrons of the Reverend Bouman, as being unfit for office.

But was the ditty part of a public discussion? Did it address the problem of corruption among officers of church and state in such a

${ }^{24}$ Scribner, For the Sake of Simple Folk, p. 228; Israel, The Dutch Republic, p. 439; De Bruin, Geheimhouding, p. 416, Van Rooden, 'De communicatieve ruimtes van de Nijkerkse beroerten', p. 137 and passim.

${ }^{25}$ Cust, 'News and Politics', p. 61.

${ }^{26}$ Van Gemert, 'De Haagsche Broeder-Moord'. Cf. Joachim Oudaan, Haagsche Broeder-Moord of Dolle Blydschap, 1l. 528, 535. 
way that the authorities could not ignore the opinions it expressed? The authorities were certainly stung. They took offence at the vilification of Justice Roosenboom. Four singers were arrested, lifted from their beds in the middle of the night and confined to the Provincial prison in The Hague. However, the singers were not charged-just removed from a volatile situation and released after some time, on bail, as a warning to behave in the future. The accusations made against the local worthies who were already deceased or indicated by nicknames went unanswered. The ditty steered clear of wider political factionalism. As a result, it could be treated simply as slander against persons in authority. The Reverend Bouman, who was in the eye of the storm, is not even mentioned. When he was at last brought to trial before the Provincial Court, his patrons escaped scot-free: he was their whipping boy. The trial dealt with the criminal charges of fraud and incitement to riot against his person only-and even he was allowed to remain in office, his honour intact, after the trial had run out of hand and the accusations had been dropped. The underlying problems went unaddressed, both in the ditty and in the judicial procedures.

Only one handwritten copy of the lyric has been found in the chaotic but ample documentation on the trial of Adriaan Bouman in the archives of the Provincial Court. The text may have not even actually circulated on paper during the troubles in Alphen itself; such songs were able to exist in oral form alone. This ensured deniability when the authorities objected: one had simply joined the singing company, probably drunk, without really knowing the lyrics, their provenance, or the persons behind the nicknames and enigmatic descriptions given in the text. The caustic criticism the ditty contains of the moral stature of those responsible for the church appears well-informed-whether this be of the truth or of current rumours is hard to say. But the ditty had no noticeable effect on the situation in Alphen, neither on the legal procedures which studiously ignored the role played by Bouman's patrons, nor on the outcome, which left everything as it was. Nor had any of the other poems, pamphlets and the satirical print devoted to the 'Alphen Pig War', all of which piously maintained the silence imposed by the stadtholder about what had happened in Alphen. ${ }^{27}$ This means that these were simply entertainment. Composers and singers poked fun at a situation that had gone bad. Their song, however, indicated resignation rather than agency.

\footnotetext{
${ }^{27}$ Spaans, 'The Alphen Pig War'.
} 
Een nieuw lietie op de wijse van Bessie

Het sijne bedroefde dagen

soo men nu claerlijk siet

de waerheyt gaat men verjagen

ogh, ogh, ogh,

wat is het een groot verdriet.

Geen men nu siet geschieden

opt dorp dat Alphen hiet

en dat van sulcke lieden

die, die, die,

het vooral en pasten niet.

De genen die hoorden te wesen

als voesters vande kerk

die maakt hem nu in desen

met, met, met,

alle valsheid sterk,

en dat met sulcke mannen

die overal bennen infaem

ja die nu sijn uitgebannen

out, out, out,

Outshoorn isser sijn naam.

Hier bij soo bennen mede noch bankeroetieren hoort getrocken uyt Leiden de stede een, een, een, brouwer soo wasser dat woort.

By die so moet men ook stellen mannen dats waer en wis die haer reeckening stellen dat, dat, dat, niet gelevert is.

Dan moet hier nog bij komen die hoog in jaren gaat

het kerkenboek kan hem wel noemen hij, hij, hij,

hier gebrantmerkt staat.
A new song to the tune of Bessie

These are troubled days

as is readily apparent

truth is chased away

oh, oh, oh,

how grievous.

What is seen to happen

in the village called Alphen

and done by people

such, such, such,

as it does least become.

Those that should be

the guardians of the church

now fortify their positions

with, with, with,

all kinds of falsehoods,

in the company of such men

as are infamous everywhere

yeah, even banished

out, out, out,

Outshoorn is his name.

And among them are also

bankrupt men, hear,

who moved out of the city of Leiden

a, a, a,

brewer, or so they say.

Moreover one has to count in

men-it is the honest truth-

who charge their customers for goods

that, that that,

have not been delivered.

Add to that number

one who is ancient in years

in the record books of the church

he, he, he,

is shamefully marked out. 
Den roffelscaef die ook mede of Hottentot soo ghij hem kent gaat stadig onrust smeden is, is, is, mede een malcontent.

Hier bij soo comen noch mede mannen van onrust gemoet die niet dan onrust smeden al, al, al,

in het kerkengoet.

Hier dient ook niet vergeten

Kees bakermoer wel oplet

hij heeft mee allerwegen sijn, sijn, sijn, voeten staag dwers geset.

Hier bij al mee behoren een backer of twee is wis d'een loopen de rotten int koorn denk, denk, denk, wattet voor volkjen is.

Den mallenboer dient niet vergeten is mede vant volkje infaam int Steeckt woont hij, wil weten ook, ook, ook, Leckje soo is sijn naam.

Hier moet men ook bij voegen die altijt opt marckje gaet met paarden en die laat ploegen dogh, dogh, dogh, docktor Olij hier ook bij staat.

Den kapitein wilt het weten van al dit volkjen hier Ary Schock is hij geheten off, off, off, de buyl drager hier.

Dan nog zijn vroutie mede sijn suster die scheeluwe kloen verdienen hier een stede want, want, want, zij moeten zijn bef omdoen.
The rough customer, moreover, or Hottentot, as you may know him, steadily foments unrest, he is, is, is, also a malcontent.

The company also contains men of unruly character who foment nothing but unrest in, in, in, the affairs of the church.

And let us not forget Kees baby-nurse, take note that in each and every way he, he, he, has held matters up.

To these also belong a baker or two, certainly one has rats in his grain think, think, think, what kind of people these are.

We should not forget the daft farmer who is also among the infamous people living in the Steeckt neighbourhood, also know, know, know his (nick)name is Leaky.

Another one of them always comes to market with horses, and lends them for ploughing but, but, but, in the company of doctor Oil.

The captain, you should know of the entire bunch is called Ary Schock or, or, or, the holder of their purse-strings.

Also his wife, as well as his sister, that cross-eyed fat-ass deserve mention here as, as, as, they arrange his collar for him. 
(cont.)

De veltheer van dees allen hola ick hout mij in toom het sou mij wel ontvallen dat, dat, dat,

heet raatsheer Rosenboom.

Sijn naam is waart te schrijven op de Haagse Groene zoo om in gedachten te blijven want, want, want, int oproeijen hij niet is bloo.
The field marshal over all wait, I should hold my tongue, or else I would disclose that, that, that, it is Justice Roosenboom.

His name is worthy to be inscribed at the Green Sward in The Hague to preserve it in memory for, for, for, he does not shy away from agitation. 


\title{
CHAPTER TEN
}

\section{EARLY MODERN LITERARY CULTURES AND PUBLIC OPINION: AN EPILOGUE IN THE FORM OF A DISCUSSION}

\author{
Jan Bloemendal and Arjan van Dixhoorn
}

\section{The Low Countries and the Public Sphere}

This book set out to discuss the relevance of the notion of public opinion to the study of the literary culture of an early modern society. We advanced a pragmatic understanding of that notion in dealing with several related aspects of public life in any given society, and certainly so in such greatly developed regions as the Low Countries. The high level of organization in public life in these countries was epitomized in the well-developed network of print and bookshops and the networks of the chambers of rhetoric, institutions of performative literary culture that stood at the crossroads of various local, regional and supraregional circles. The rhetoricians maintained tight-knit networks on various levels through their regular exercises, their involvement in local and interurban festive culture, and the organization of (supra-) regional festive literary contests. The chambers were the institutional heart of a much broader civic culture in the core regions of the Low Countries and literary practices were an essential part of that culture. The supranational respublica literaria was in many ways linked to the worlds of print, rhetoricians' culture and performative literature. The learned humanists of this Latinized world maintained international networks, witness the many vast correspondences that have been preserved in manuscript and print. For humanists and vernacular rhetoricians alike, literary practices were essential, and both groups spread news and aimed to influence the views of friends and fellow citizens.

The people of the Low Countries could and did engage in debates about a variety of issues, at local, regional and interregional levels through these institutions, networks and other centres of literary culture. Literary institutions and practices created a 'system' that enabled the cross-sectional and interurban circulation and appropriation of ideas, knowledge, literary techniques, rhetorical skills and reputations. 
The system was dependent on the publics that engaged wilfully (or otherwise) in public debates and in the formation of consensus views and antagonisms. Publics were always divided, constrained and influenced by widely shared beliefs or by what were believed to be majority and minority views, but recipients could of course also affect and change such views. As several contributions to our volume show, early modern opinions did not necessarily express the voices of authorities, although they did not automatically oppose them either. Contrary to what the Habermasian notion of an early modern one-way 'representative public sphere' suggests, the sixteenth and seventeenth centuries did abound with controversy; from debates engendered by the Lutheran, Radical, Calvinist and Catholic Reformations to international, national and local political discussions such as constitutional issues, questions of war and peace, poverty, and good governance. These controversies always show a relatively high level of attempts to convince others. Or rather: we often only know about them from the greater number of persuasive texts inextricably intertwined with controversial events, issues, people and institutions.

Of course, this does not imply that in early modern society the connection between social debates and the implementation of proposals supported by the population was self-evident. In our view, however, this is not a precondition for the existence of the formation of public opinion. The contributions to this volume all add to our understanding of the making of public opinion as a communicative process. They question, qualify or affirm our initial views, and in our view they point to seven key problems and issues relevant to the study of the role of literary culture in the early modern process of the formation of public opinion.

The first issue to take into account is: what is the significance of being (part of) a public and how does this affect the study of public opinion? In other words: how do publics come into existence, what opinions do they hold, how can we learn about these views and how do we study them? Secondly, if we study people who seem to intervene in attempts to change 'public opinion', what exactly do we mean by impact and how do we measure influence? Thirdly, if people try to influence public opinion, they wish to be heard and seen, which makes accessibility and observation crucial issues in our understanding of the forming of public opinion. Fourthly, since the making of public opinion is a process involving people who want to be noticed and others who might want to silence them instead, both the restrictions 
introduced by formal or group censorship or self-censoring, as well as the means to evade or overcome censorship are crucial. Fifthly, we believe that it is important to distinguish carefully between attempts to influence people's views and outright propaganda. A sixth issue concerns the sources useful for the study of public opinion, and the way they can be studied, not as mirrors, but as factors in the process of the formation of public opinion (both on the level of individual minds and of collective interaction).

This then leads to the seventh issue, the final question of our study: how are literary culture and the formation of public opinion related and how should we study these categories of social life in conjunction with each other on a theoretical level? In other words, how can we study the qualities of a text with respect to public opinion-formation, how do we discern opinions on public issues in literary texts, how can we determine the position that the author might have taken in public controversies, and how should we establish whether that position is representative in relation to other opinions expressing similar views? We will briefly address the seven key issues in an attempt to synthesize the most important challenges, problems and solutions put forward by the contributions in this volume.

\section{I: Publics, opinions AND the PROBlem of REPRESENTATIVENESS}

The link between spaces and publics is crucial to the study of public opinion since views and texts have their origins in communities and networks. We must discern clearly between local, regional, national and international publics, while always recognizing the interplay between them. The 'shape' of publics and the spheres in which problems are dealt with change with the developing issues. The emerging controversies, like publics, are always local too; however national or international their focus, they need not only virtual but also real locations in which to occur and for people to interact in.

The interplay between geographical space, institutional arena, and local circle is nicely shown in the case of the ditty sung in Alphen aan den Rijn in the 1680s, as discussed by Spaans. The song expresses anger at the role of local authorities in an ecclesiastical conflict turned political. It shows engagement in the conflict on the part of the singing locals. It expresses views, singles out key figures and sides with one party, dismissing the other, in the burlesque terms typical of early 
modern satire. Instead of being mere entertainment, the ditty was fully part of the highly charged politicized culture in the village. It dealt with an (initially) institutional conflict in the circles of church and (local and central) government that became the subject of intense observation by larger segments of the population, while more people also became increasingly engaged, and not merely as passive bystanders but as active participants. People incited their children to harass those of the other party by following them in the streets, taunting them with satirical songs.

The interplay between local, national and international publics is evident in controversies that were acted out on regional and supraregional levels. There too, the local context from which conflicts spiral into wider spheres (and back to local sites) is crucial in explaining the dynamics of the process of opinion-formation. This is clearly shown in the case of Grotius's epitaph for Arminius as discussed by Van Oosterhout. The poem intervened in a local event and controversy which arose after the death and burial of a well-known theologian and the recent theological disputes at Leiden University between the followers of Arminius and his colleague Gomarus. The poem-which, in accordance with the learned nature of the deceased and of the controversy, addressed a relatively small audience of learned Latinized readers that soon grew and did so beyond the control of its creator, added to the increasingly public nature of the conflict. The case of Grotius's poem shows how such a text could add fuel to a controversy. Its later translation into English also enabled a transition from a sphere of learned debate to even wider vernacular audiences. Although the poem originated from the tight-knit Neo-Latin community of Leiden University, it soon entered wider Neo-Latin networks and, despite its author, did play a role in the gradual development of distinct Arminian and Gomarist political movements. Owing to his irenic views and the responses to his poem, Grotius unintentionally moved to a leading position in Arminianism, first on a national level and then, again without his active consent, in another national arena: England.

The example of Anna Bijns, as discussed by Keßler, also shows how her fight to preserve and purify the Catholic faith of the Low Countries linked a local community of Franciscan supporters in Antwerp to wider networks of Franciscans, priests, humanists and rhetoricians in Ghent and Bruges. If the Stevijn she mentions is to be identified as Stevijn vanden Gheeste, for example, he linked Bijns to Eduard de Dene, a Bruges poet and playwright who acquired his interurban fame as a 
rhetorician in the 1560s and was a loyal Catholic. Between the 1520 s and 1560s, such groups and networks provided a creative environment and a supportive audience which enabled Bijns to wage her fierce polemics against Protestants. The extant manuscript collections of her poems reflected these local communities, while the Dutch and Latin printed editions reflected and built the larger networks, in attempts to reach out to wider (even international) audiences and provide them with the polemical tools to attack Protestants locally. Several Catholic communities were stimulated by Bijns's polemical qualities. On the other hand, such a polemical literary culture not only emerged from these local communities and regional networks, but also helped to create, sustain and solidify them into a movement that was seeking its own leadership in higher circles as well.

Bijns became a central and iconic figure in a regional network of local communities involved in concerted efforts to defend and rebuild the Catholic Church in the Low Countries and silence the Protestants. Helmers shows how, two centuries later, in the young Dutch Republic of the 1650s, a (loosely organized) network of playwrights and poetsoften of non-Calvinist conviction and linked to the States partyengaged in strenuous efforts to influence Dutch policies towards Commonwealth England. Most of them were linked to the Amsterdam City Theatre and its literary networks which dominated the theatrical scene in the Dutch-speaking Low Countries as a whole from the 1630s onwards. In their efforts, the poets and dramatists associated with the Stuart royalist lobby against the radical Commonwealth puritans, who, in their view, might have represented a dangerous model for the Calvinists which controlled the Reformed Church of the Dutch Republic. The dramatists and poets also allied themselves with the Orangist cause, which after the death in 1650 of William II of Orange-who had become very controversial by trying to convince the States of Holland and Amsterdam in particular to intervene in England-formed an opposition to the States party which had decided to leave the office of Stadtholder vacant. These poets and dramatists also opposed the regents of Amsterdam who supported the States and who constituted the political powerhouse of the Dutch Republic, even though many of these writers were part of literary networks that included leaders of the States party. Thus the playwright Jan Vos belonged to the inner circle of Joan Huydecoper, the powerful burgomaster of Amsterdam and opponent of Orange in 1650. The Rotterdam poet Joachim Oudaen was a friend of Johan de Witt, Grand Pensionary of Holland and leader of 
the States party from 1653 onwards. Helmers' case shows how an issue of international politics became intertwined with national politics and the dynamics of partisanship.

Helmers' case helps to unravel the fact that many playwrights, poets and pamphleteers promoted a similar cause, since their consensus in itself does not mean that they were representative of large numbers of people. The Dutch Revenge Tragedies dealing with the execution of Charles I indeed may very well have tried to convey the impression that the revenge discourse of 'martyrdom' and 'parricide' resonated with the public. This suggestion is seemingly strengthened by the absence of opposing views. Still, the implicit 'representativeness' of a consensus view remains a fiction in the sense that it is difficult if not impossible to verify the general attitudes of the Dutch people versus the English Commonwealth. In any attempt to measure the potential effects of the plays and the consensus view that they defend, it hardly matters whether or not theirs were mainstream views. However, if they had succeeded in solidifying the impression that the general public agreed, the fiction might then successfully have influenced the sense of the climate of opinion among decision makers, and thus the pressure under which they operated. The fiction might also have convinced and pressured the theatre and reading publics to accept the framing of the conflict in terms of 'martyrdom', 'patricide', 'revenge', which must have linked the death of Charles I to the murder of William of Orange and provided fuel for debates on the topic.

The problem of research into historical opinion is that we will never know what most people believed. Therefore, every account which claims to reflect public opinion should be interpreted with the greatest caution, since it may well express just one voice in public debate or mistake the strongly expressed views of a minority for that of the majority, or stem from the principle that people often take the views of their immediate environment to be the mainstream opinion. The fundamental rule should be that historians ought always to consider a view that expressly or implicitly invokes that 'public opinion' comprises first and foremost the ideas of the author, and then only with great care attribute them to a segment of the population, be this a majority or a minority.

When, in his Auriacus (1602), the young Leiden scholar Daniel Heinsius referred to the Flemish sorrows inflicted by Spanish tyranny, he implicitly invoked a moral duty to free Flanders. This was the opinion of one person, but since it was voiced in a play, it is likely that he 
expected the audience to at least identify with these Flemish sorrows and the notion of Spanish tyranny, particularly since he linked the issue to the murder of William of Orange and the subsequent revenge by Prince Maurits. The more delicate question, however, is how many people among the play's live audience or among the readers of the printed edition would have shared Heinsius's call for revenge in yet another attempt to 'free' Flanders? Did he voice the opinion of a lobby of Flemish immigrants? What did native Hollanders among his audience think about this topic? And what about the people of Flanders on whose behalf Heinsius implicitly claimed to speak in favour of a continued war effort? That he felt compelled to try to convince his audience indicates that support was not universal. In 1609, his fellow citizen Jacob Duym, a nobleman from Brabant, a former captain in the States army and a Leiden rhetorician, borrowed Heinsius's theme of the assassination of William for a similar cause. In the run-up to the Twelve Years' Truce, the options were to make peace with Spain or continue the war. Duym spoke in favour of war too. As Groenland points out, he expressed an opinion that could have been shared by many or by a few-we just do not know.

\section{Contemporary notions of public opinion}

The appearance of the fictitious representation of public opinion in many texts shows that people were familiar with the notion, and quite likely were aware of the problematic (numeric) nature of such representations as well as of their impact on the way people estimated mainstream views and trends. In fact, the example of Cornelis Everaert as discussed by Mareel shows that at least some of the early modern literate inhabitants of the Low Countries were not only highly aware of the existence of public opinion phenomena, but also had sophisticated views about their dynamics. The argumentation structure of early modern Dutch allegorical theatre (and many of the early printed pamphlets) already provided a model of everyday small talk, conversation and discussion, with protagonists representing mankind, the citizenry, the government or the clergy, debating a particular problem. ${ }^{1}$ These plays dealt with a variety of topics, some of them highly controversial. Everaert's plays also explicitly represent and discuss the world

\footnotetext{
${ }^{1}$ See Spies, “'Op de questye...”' and Ramakers, 'In utramque partem vel in plures'.
} 
of gossip, newsmongering, and public formation of opinion. The 'popular' voices of Everyday Chitchat and The People's Gossip represent the circulation and discussion of bits of news among the people. These 'popular' voices often disagree with the 'official' voices such as The Will of the Lord. Mareel contends that this world of the speedy transmission of news as represented in Everaert's plays, corresponds with what the study of chronicles, diaries and court records has brought to the surface. He rightly points out that these plays do not just illustrate everyday reality but instead offer an insight into the ways in which the nature and the workings of these phenomena were understood.

A fundamental notion in the early modern perception of public opinion was the apparent volatility of the public. In Everaert's words, it would be hard to draw any consistent conclusions about what the public was thinking, 'because the opinion of the people is so unstable and changeable'. This principle of social life was summarized in the classical proverb, quoted, for example, in the chronicle of the beginning of the Revolt by Marcus van Vaernewijck, 'daer veel volcx es, daer zijn veel zinnen' (so many people, so many opinions), ${ }^{2}$ or in the Latin of Erasmus's Adagia, 'quot homines, tot sententiae.. According to Dirck Pietersz. Pers's Dutch appropriation of Cesare Ripa's Iconologia (1644), a woman in elegant dress should represent 'Opinione', a concept translated into Dutch as 'Gemeen Gevoelen of Waen' (Common Feeling or Delusion). ${ }^{4}$ In order to stress how easily she might be convinced, Opinio is pictured with wings on both hands and shoulders.

The Iconologia defines Common Feeling as 'probably anything that takes place in the minds (sinnen) and the imagination (inbeeldinge) of a Person', and 'since there are so many different minds and feelings', it follows that there is also an enormous number of opinions, as recognized in the common proverb 'so many heads, so many feelings'. ${ }^{5}$ The many wings, the Iconologia amplifies, stress the readiness

2 See Van Vaernewijck, Van die beroerlicke tijden 8, 28, ed. Vanderhaeghen, vol. 4, p. 130. See also dbnl.

3 Erasmus, Adagia 207 (I.3.7). The notion of the volatility of the people also dates back to Antiquity, witness, for instance, the representation of Fama (the volatile rumour) in Virgil, Aeneid 4, 173-77.

4 See the image of Opinio in the contribution by Spaans.

5 ''t Gemeene Gevoelen of Waen is misschien, al 't geene dat plaets heeft in de sinnen en in de inbeeldinge van den Mensch: of ten minsten in dat alleene, dat niet waerschijnlijck is te bewijsen, en om datter verscheyden verstanden en genegentheden zijn, soo zijnder oock oneyndlijcke meeningen. Waer uyt dit gemeen spreeckwoord 
('vaerdigheyt') with which opinions or common feelings are instantly accepted and then rejected again. Iconologia's final (rather pejorative) association depicts Opinio hurrying through the world, mostly wearing the dress of ignorance, wherever she might go. ${ }^{6}$ This female image of Opinion running through the world quite likely refers to a view, often invoked in early modern Europe that associated women with gossip and the spread of rumour. ${ }^{7}$

In a refrain with the stok or sententie "Want alzo menigh hooft Also menich zin' (for so many heads, so many feelings), the Bruges rhetorician Eduard de Dene (1505-1576/79), confronts true Reason (Reden) with Opinion, whom he clearly associated with conceit, vain learning, heresy, wisdom of man (instead of wisdom of God), and sophistry. In a manuscript containing his ambitious poetry anthology, the Testament Rhetoricael (1561), a brief introduction preceding the refrain summarizes the message of De Dene's rhymed argument:

Carnal Feeling, Opinion, Blinded Mind and Ingenious Wit, please believe me, these four, give council and assist, in concealing and embezzling the truth. It often goes topsy-turvy as it turns out: People's opinions govern the world. ${ }^{8}$

Opinion in these views is a many-headed monster, ignorant, easily persuaded, and highly volatile. Such pejorative notions circulated in early modern Europe, as part of the Classical heritage and, certainly, as the result of the personal 'experience' of people who believed themselves to be governed more by Reason than by Opinion. Of course, this does not necessarily mean that Opinion's rather elitist and pejorative view was mainstream. Neither does it follow from this that Opinion,

komt, soo veel hoofden, soo veel sinnen.' Pers, Cesare Ripa's Iconologia of Uytbeeldinghen des Verstants, p. 152.

6 'De vleugels aen handen en schouders, betoonen de vaerdigheyt, waer mede de opinie of het gemeen Gevoelen, wort aengevat en wederom verworpen, jae by nae op een tijt en oogenblick. Rennende in der yl door de gantsche Werreld, dragende ten meestendeel het kleed der onwetentheyt, waer zy oock gaet.' Ibidem.

${ }^{7}$ See, for example, Capp, When Gossips Meet; Cowan, 'Gossip and Street Culture in Early Modern Venice', p. 315; Horodowich, 'The gossiping tongue'.

${ }^{8}$ Eduard de Dene, Testament rhetoricael, ed. Waterschoot and Coigneau, vol. 2, p. 81: 'Vleeschlick zin / Opinie / verblendt in tverstandt // midsgaders vernuft inden gheest / wilt Luusteren // dese viere gheuen Raedt / en bieden dhandt // Omme de waerheyt verborghen en verduusteren // Tghaetter Al auerecht meest ghekeerelt // Opinien der mensschen Regieren de weerelt'. Also dbnl. 
in the words of De Dene, did not govern the world. ${ }^{9}$ Despite such reservations, however, it is safe to assume that Opinion's pejorative view was prominent among members of government. The correspondence of Margaret of Parma, governess of the Low Countries from 1559 to 1567, for example, abounds with the view that people are easily deceived, particularly women, the unlearned and the young, which made them vulnerable to all sorts of doctrines. This principle made it imperative for anyone who was interested in the support of the people to invest in attempts to win their hearts and minds. It also put a huge responsibility on the shoulders of the deceivers and those who had to defeat them. In fact, evidence from the persecution of heretics in the Low Countries does indeed show that opinion leaders were punished more severely than their followers. Early modern rhetorician drama engaged with these dynamics by making the wise (councillors, scholars and rhetoricians) and the deceivers (the so-called sinnekens) fight for the minds of figures representing Mankind, the citizenry and all kinds of 'ordinary' people.

\section{II: IMPACT, INFLUENCE AND AUTHORITY}

The idea of the volatility of public opinion and the responsibility given to opinion leaders, texts, images and performances in the early modern period show that contemporaries believed that it was possible to influence the opinions of the public, and that this was something important. Of course, this is no 'proof for actual impact, and measuring the impact of a publicly expressed view remains a nigh on impossible task for the historian. An important factor in the potential effects of a publicly expressed opinion which does, to a certain extent, lend itself to investigation is the authority of the 'speaker' and his or her texts.

Literary culture offered 'speakers' various means to claim authority. De Dene's contrasting positioning of Reason and Opinion can, for example, be interpreted as a way to claim the position of a wise person who voices a stable truth, instead of uttering just another interchangeable opinion. An author's attempt to associate with an accepted source of authority such as the Scriptures, the Ancients, Reason, Learning or Common Sense, is just another way to become a source of reference to

\footnotetext{
9 For a positive view on public opinion, see Van Dixhoorn, 'The grain issue of 1565-1566.
} 
others. Rather, implicit sources of authority could be the age, gender, education, class and institutional status of a 'speaker', or his or her historical moment in time. The case of Anna Bijns shows how women experienced different constraints and possibilities than men in spreading their opinions and making them highly regarded and potentially influential. Since authority is always attributed, often claimed, but never self-evident, it was also derived from the institution, group, network or faction to which the author belonged. Bijns, for example, partly derived her authority from an institutional base, i.e. the Minorites or Franciscans, and from a close-knit network of orthodox Catholics. Clearly, she will not have had much authority among Lutherans, just as Luther did not have much authority among Catholics.

There are several ways of acquiring authority that are relevant to the study of the role of literary culture in the process of public formation of opinion. Authority can first be granted on the basis of attributed representativeness: in the case of someone considered to be speaking for the people, a majority, or a considerable group. Anna Bijns acquired such a 'representative authority', with the Franciscans promoting her as their spokeswoman. A second type is the 'intrinsic' or 'ethical' (in a rhetorical sense) authority, with someone speaking as an expert on the matter, as did Grotius in his poem on Arminius. A third type of authority can be derived from the outsider position. 'Outsider authority' can be acquired by someone claiming to look at a case as an outsider (an 'other') and who, from that position, can express new and revealing opinions. This position might be taken by foreigners in travel reports, but might also, and more frequently, be represented by internal 'others', such as, in early modern times, the fool and other literary personifications of the simple folk (or common sense). A fourth type is the 'authority of the inspired', derived from inspiration by God, angels or saints. The 'exceptional' role attributed by the Fransiscans to Bijns in what they thought to be apocalyptic times in which Lutheranism spread also relates to this type of authority. In many cases, such as those of Bijns, a person or institution's actual role will combine various types of authority.

An author who acquired (rather than just claimed) authority could become an important agent in the process of opinion formation, an opinion leader acquiring attention and reactions from wider audiences. In his epitaph for Arminius, Grotius presents himself as a scholarly humanist, claiming for himself the authority of an expert. The way his Latin poem circulated points to the role of networks in the creation 
of his authority and the impact of his arguments. He might also have used his poem about Arminius to make a name as a theologian. He certainly used his theological knowledge and reputation to present an irenic stance in the controversy around Arminius's views. The role of a learned community in creating authority also helped Bijns, whose skilful mastering of vernacular rhetorical culture was acknowledged by the Franciscans and other experts in theology. Thus the use of a certain language, Latin or vernacular, and literary techniques, played an important role in the creation of authority. The young Heinsius (he was twenty-one at the time) claimed some authority by writing a fullyfledged Senecan drama. He might have done so in order to restore classical drama in the northern Low Countries, to acquire a position at Leiden University, or to exhort Maurits not to abandon the southern provinces. He did so in tragedy, a genre familiar from Latin literature. His views were then (skilfully) adapted for vernacular audiences by the learned rhetorician Duym.

Naturally the impact or influence of these texts on audiences cannot simply be assumed from the skills and authority of their author, their language, the quality of the production (be it a performance or a printed book or a manuscript). The effects on the minds of individual members of the audience or reading public must be assumed to have been as diverse as were the people, depending on the intensity of their attention, their knowledge of the topic and their linguistic and interpretative skills, experiences and preconceived views; all impossible to measure for the historian. The task of assessing influence is hampered further by the two-step-flow principle of mass communication: attentive members of the audiences and readers are likely to have discussed their theatrical or reading experiences with others. ${ }^{10}$

Impact and influence can be measured on various levels, and the setting of an agenda is one of them. ${ }^{11}$ This means that an important form of impact is achieved when an audience is informed of a certain problem or certain views, which might invite or even seduce them to think about or at least make them attentive to the issues. This might then lead to the acceptance of the issue or of these views as important matters that need further attention. This second form of impact might be achieved when members of the public come to view an issue as their own, even if they would not agree with the views of the one who

10 For the 'two-step-flow theory', see the introduction, p. 25.

11 See also Bloemendal, 'Receptions and Impact'. 
initially made them aware. This might lead to a third form of influence that is achieved when the original messenger comes to be seen as the problem and becomes the centre of controversy. In short, the fact alone that people are 'forced' to deal with an issue should be considered as a form of influence with an impact on the course of (a smaller or larger segment of) society. An author or text might also be successful in effectively framing an issue. For example, if people accepted the Dutch playwrights' representation of the execution of Charles I as an illegitimate regicide, the King as a martyr, and the act as a call for revenge, this already could be claimed a success, even if people might not have accepted their call for war against England.

In an early modern society such as the Low Countries, literary texts were very important in creating a public pool of arguments, names, and frames that could be used to interpret events and issues, as is shown in the demonization of the Catholic Church by the Dutch humanist Gnapheus, or that of the Lutherans by Bijns, of the English Puritans by Dutch playwrights, of the local minister and other authorities by some inhabitants of Alphen, of Protestants by Jesuits, and of Spanish Catholics by English writers. A similar effect might have been achieved by Heinsius's portrayal of the 'sorrows of the Flemish', Duym's and Heinsius's portrayal of William of Orange as a hero, or Van de Wael's portrayal of Maurits as a new David. Grotius might have persuaded some of his readers into a more favourable view of Arminius despite a continuing disagreement in matters of theology, or he might have succeeded in convincing others that the issues had to be dealt with in the scholarly community instead of openly. The problem of influence is shown in the fact that Grotius's intervention provoked others to react by doing precisely the opposite: making the controversy public in the vernacular, as Gomarus did. An unfavourable effect, however, is still an effect. The arrest of the Alphen singers is another example of an unintended form of impact (which gave their song further publicity). Whatever impact one is looking for, it is important to distinguish between effects on the opinions of populations and effects on the fictive public opinion, or the idea people have or with which they are confronted, or what the general public supposedly believes.

III AND IV: THE PUBLIC EYE AND CENSORSHIP

The ditty sung in the Alphen 'Pig War' is not only an example of the way in which texts could make an impact, but also shows that 
interested outsiders were actively gauging the conflict. The fact that the observation of the conflict was expressed in a song was part of what made the conflict into a public phenomenon. The public eye already has an impact when insiders in a controversy act upon their awareness of being watched. Whatever the ditty accomplished politically and institutionally, and whatever its message conveyed to the ultimate settling of the conflict, it already worked in the conflict as a reminder to others that people were watching and evaluating the conflict, and forming their views. Each time ditties about the conflict were sung when people were at work or as a way to attack and profile people, they helped to keep the issue on the public agenda. Singing the ditty was therefore partly what made the controversy a public issue in the first place. The same dynamic can be found at the highest international level with the media attention and spin surrounding the 'Spanish Match', the intended marriage between Charles, Prince of Wales and the Spanish Infanta Maria in 1623 as discussed by Moser. This media attention is what generally creates 'historical' events (and gives them their names).

The importance of being noticed is closely linked to the idea of the public. People watch and observe and are being observed. ${ }^{12}$ Or they take others who have made observations as their witnesses. Catching the public eye is one of the first goals of literary techniques that help the ideas expressed to be noticed and memorized. As we argued before, the fact alone of being noticed means having some impact or influence. Grotius distributed a poem in praise of Arminius among his friends and that in itself was already an act of seeking attention which extended beyond the effect and influence that he might have achieved through taking part in conversations. The fact that a text is fixed and encoded in a literary way suggests an orientation towards an audience. This can therefore only mean that the author or the printer wanted it to be heard, read and/or seen, and was aiming to wield some power over the audience's minds, particularly if the text showed a superior mastery of form, language and argumentation. Such a text could be disseminated in print, manuscript or performance, and these are all attempts to catch the public eye. In early modern times this

\footnotetext{
${ }^{12}$ See for example, Schlögl, 'Politik Beobachten: Öffentlichkeit und Medien in der Frühen Neuzeit'.
} 
was already recognized, witness the 'sharpness' attributed to 'a honed tongue' by Pieter Cornelisz. Hooft.

The power of tongue and pen was clearly acknowledged in the early modern Low Countries, as elsewhere. The dangerous aspects of this power called for a balancing power, which was laid out in moral and legal principles concerning the limits of free speech. ${ }^{13}$ Authorities and ordinary people alike could take action against those who, in their view, had broken these rules, or had aimed to prevent people from taking action. Various policies of censorship, self-censorship and ways to speak the truth without insult or transgression of rules emanated from the recognition of the dangerous power of speech. As Mareel has shown, the Bruges rhetorician Cornelis Everaert noted in the manuscript of his Van Groot Labuer en Sober Wasdom that the performance of the play was blocked 'because the truth had not been concealed'. This raises the question as to whether this 'truth' could have been revealed in ways that would not have caused unease. One of the ways to evade censorship might be to veil the message in allegory or mythology, thus not directly attacking a contemporary authority or group of people. An obvious way to evade the effects of censorship would be to conceal the author and printer of a work. The famous and controversial Amsterdam poet and playwright Joost van den Vondel for instance had his Maria Stuart (1646) published anonymously and with a false imprint, 'In Cologne, at the old printing house' ('Te Keulen, in d'oude druckerye'). He did so to prevent censorship from the authorities, but it should be stressed that literary texts might also be self-censored through the author's assessment of the public's reaction.

We should not forget, however, that early modern society in the Low Countries seems to have left some space for free speech if delivered in certain forms, such as those embodied by the fool. The fool or 'foolish' texts could present controversial views under the pretext of 'folly', as Erasmus famously did in his The Praise of Folly. This does, not mean, however that the position of the fool was without limits; problems could still arise if the object of attacks was singled out explicitly or if a text or act became associated with controversy. The Praise of Folly, for example, was put on the Index with all Erasmus's other works. To some extent, a similar logic of freedom as embodied in the 'timeless' culture of laughter evoked by comical texts and

${ }^{13}$ Weekhout, Boekencensuur in de Noordelijke Nederlanden. 
performances might also be discerned in the 'higher' forms of literary genres epitomized by the tragedy. In this case, the topicality of a play might be veiled somehow by forcing it into a 'timeless', universal logic of the rise and fall of the high and mighty. Tragedy for example, required the fall of lofty persons through their own faults or those of others, moulded into the Aristotelian unity of time and place. Through the constraints of the genre, the fate of William of Orange or Charles I as represented in tragedy was taken out of the immediate political (and therefore potentially provocative) context, and sublimated into the universal logic of the tragedy. The world of performance had, of course, its own dynamics in relation to censorship. This was exemplified in the performance of poems and songs which, unlike plays, do not need a set time and place, require no organization, and instead can be disseminated physically and verbally by individuals. The authors of such texts, who, if known, could be held responsible in law for the views they voiced in their work, could easily remain unidentified and the ephemeral character of reciting a poem or singing a ditty made pre-emptive censorship impossible and punishment problematic. The fact that early modern authorities tried to impose self-censorship by banning provocative texts from the public realm already attests to the impact they were expected to have.

\section{V: OPINION MAKING AND PROPAGANDA}

Historians easily turn to the notion of propaganda when they are confronted with attempts to influence others. However, most interventions in the process of opinion-formation come from individuals and small groups, voicing their opinions among many others, without having the ability to control the flow of news and opinions. We believe it is crucial to distinguish between, on the one hand, individual attempts to influence people's opinions and, on the other hand, outright propaganda. In general, propaganda is defined as a systematic and repeated attempt to influence people's minds:

Propaganda is neutrally defined as a systematic form of purposeful persuasion that attempts to influence the emotions, attitudes, opinions, and actions of specified target audiences for ideological, political or commercial purposes through the controlled transmission of one-sided messages (which may or may not be factual) via mass and direct media channels. ${ }^{14}$

${ }^{14}$ Nelson, A Chronology and Glossary of Propaganda in the United States, p. 233. 
Propaganda, then, is a process-a form of manipulative communication designed to elicit some predetermined response- 'the organized spreading of special doctrines, information, ideas or beliefs to promote or injure a cause, group, nation, etc. ${ }^{15}$ Manipulation, exclusion (of other views), organization and control, and thus a link to power, are the features of propaganda. Because of the haphazard and openended nature of most of the public process of opinion formation we are convinced that the term propaganda should be used strictly for concerted and systematic efforts to manipulate people. Even if more people try to push similar views at the same time, or if someone tries to repeat another's efforts, in the absence of a powerful organizational centre or of a propaganda machine which promotes a single view while aiming to exclude others, we should be careful to speak of propaganda. It is also important to consider the context of efforts towards propaganda. An organization responsible for such efforts will, by definition, be unwilling to engage in open discussions of the issues at stake. However, if these efforts take place in a totally open and heterogeneous society, with well-developed cultures of criticism, the term propaganda should also be used with caution. This is because, despite the intention of the propagandists, the communicative practices with which they are confronted are beyond their control. It might then be useful to distinguish carefully between the propagandistic intent and its practice or effect.

For instance, the plays dealing with the execution of Charles I, as discussed by Helmers, certainly promote similar views. However, there is no evidence of a well-organized network or even the active engagement of a central authority, such as Charles II's entourage, in sponsoring and organizing these playwrights for a concerted campaign to change the minds of the Dutch and their government so that they would favour war. If there would have been a royalist plot to influence Dutch people or their authorities, the plays could have been considered part of a propaganda campaign, while in this instance the evidence only points to a commonly held opinion among an informal group of like-minded poets. In the case of Bijns, the fact that a network of the Antwerp Minorites and other clergymen was active in the promotion and printing of her poems comes close to a systematic effort to influence Roman Catholics to defend their Church and others to return. This was, however, also a very special project, with the poems most

${ }^{15}$ Ibidem. 
likely emerging from Bijns's activities in the local community. They were not, or so it seems, the result of a continuous and organized intervention, but rather of the manifold attempts by individuals and smaller networks of Catholics to counter the rise of Protestantism. The Spanish and English campaigns against the Spanish Match discussed by Moser are probably closest to a propaganda effort, if they were indeed orchestrated by Olivares and Buckingham or their courtly entourage. Even then they were conducted in unfavourable environments and represented a view that ran counter to the official line in both Kingdoms.

Demoed's analysis of the Dutch humanist Gnapheus's scholarly and polemical career, focussing on his play Hypocrisis, also shows how problematic the use of the notion of propaganda is in the context of the Reformation. The Hague-based Latin teacher Gnapheus became one of the early leaders of the movement for Reform in the Low Countries. Although he was arrested in 1523 with Jan de Bakker and Cornelis Hoen on suspicion of heresy, he was only temporarily incarcerated then, and again in 1525. After he was banished from the country in 1528, he moved to Elbing in the equally Catholic Kingdom of Poland. This suggests that he had not yet broken with the Church of Rome. Gnapheus clearly was one of many humanists and vernacular literati who helped to carve out Reform projects locally while striving for a leading role on a regional and international scale as well. Gnapheus was accused of Sacramentarianism and Anabaptism in Elbing, and later showed interest in Zwinglianism. His individual style, Demoed's analysis shows, was derived from Neo-Latin humanist and vernacular written, printed and performative cultures. His individual struggle for reform might have been the reason for his expulsion from Königsberg, although we should be careful in casting him as the victim of a unified Lutheran Orthodoxy. It could be significant that his heresy trial began in 1547, following the death of Luther in 1546, which might have sparked controversies about the future of Lutheranism. In short, Gnapheus's interventions for evangelical Reform points to a highly personal search for public leadership in debates and controversies concerning the Reform movement rather than an organized propaganda effort on behalf of a fixed set of opinions against another easily identifiable set of doctrines. The Catholic Church, which these scholars first reified and then attacked, was already deeply heterogeneous in itself. 


\section{VI: THE SOURCES FOR THE STUDY OF PUBLIC OPINION}

The formation of public opinion is a communicative process that involves the interaction of individuals and larger groups, cultural practices and institutions. In this process, people's perceptions of the effects of those interactions play a crucial role. To put it differently, the process of public opinion-formation is characterized by a continuous evaluation of events, institutions, groups and of people's actions, words and thoughts. This also means that the number of sources that provide evidence of the process of public opinion-formation is huge. In this book, we have focussed on a highly visible and obvious group of sources which nonetheless have largely been ignored by historians: literary texts. This focus on literary texts and, by extension, literary culture is inspired by the contextualization approach in writing on literary history, as well as by the more recent trend of focussing on the performative qualities of literary texts that were indeed part of a larger culture of eloquence and wit. ${ }^{16}$

The view that the categorization of early modern texts into literary and non-literary is based on a modern taxonomy of genres, which is very different from the early modern view that made no clear-cut distinctions between written texts, is relevant to the study of the role of literary texts in the public process of opinion-formation. In fact, literary culture in general should be considered just as crucial for the understanding of early modern opinion as the modern media are worthy of study for the understanding of modern public opinion. This means that historians need to take recourse to the study of literary texts and literary culture to understand the dynamics of opinionformation: continuing, of course, to make use of their more traditional sources such as archival material, as Moser effectively demonstrates. It also means that literary historians interested in the study of literature beyond formalism, structuralism and post-structuralism, need to turn to sources and research methods traditionally used by historians and historical sociologists, while both need to link their research to the larger discussions about public opinion in the historiography of modernity, philosophy and the social sciences. This is important because we believe that the formation of public opinion is at the heart

${ }^{16}$ Van Dixhoorn, Lustige geesten; also O'Callaghan, The English Wits. 
of early modern literary cultures, both Latin and vernacular, which interacted on various levels, as is shown in several of the contributions in this volume.

Should literary sources be our most important source in the study of public opinion? If that would be our argument, early modernists would make the same mistakes which theorists of modern public opinion, with Habermas as their protagonist, have made. Instead of isolating and privileging the sophisticated means of communication controlled by rather small groups of society (be it the mass media of modern or the literary cultures of pre-modern societies), these texts should be studied as unique interventions flaring up in a continuous chain of other unique, but perhaps everyday interventions (spoken and body language, acts, images of people) and the (actual and possible) perceptions of those interventions by the same or other people. The focus of research should be on a series of interventions by an author (and on his or her means of publication, such as in the case of Bijns or Gnapheus) or on a specific text (such as in the case of Grotius, Everaert, Heinsius and Duym). It could also take the form of an extensive analysis of a Dutch fragment report on a theatrical event at the occasion of the Spanish Match, as Moser shows. Furthermore, the focus could be on a larger controversial issue (such as the Spanish Match and the Winter King, the royalist cause in Holland in the 1650s or the Alphen Pig War). Whatever the focus, a text clearly should be studied in all cases as a communicative act that cannot be seen isolated from the author, from his or her network and the communicative practices (often controversial) in which he or she was engaged (deliberately or otherwise). Certainly the range of sources that show these communicative practices extends far beyond the literary text, its paratexts and peritexts, and the materiality of the scribal or printed copies of the text. They already start with evidence of the live performance of a large number of texts which, during each performative event, produce a unique, transient version of the text and its interaction with producers and audience.

Moser's exploration of the status of a seventeenth-century Dutch fragment describing such an ephemeral event most strikingly highlights the methodological caveats involved in the use of literary texts as sources for the study of early modern public opinion. Her convincing proposition is that the fragment is the indication of an attempt to write, translate or copy a text in line with a (Protestant) polemical tradition (invoking anti-Protestant performances that probably never 
took place) and, more specifically, English polemics surrounding the Spanish Match. This text might either have been intended for further circulation in print or in manuscript. Moser rightly argues that in the reconstruction of a case of moulding public opinion every small particle of evidence should be taken into account, including (fragments of) literary texts, whether in print or in manuscript. These indications of the web of events, representations and interventions can be used to reconstruct what actually happened or what people believed to have happened (or wanted others to believe). Provided they are related systematically to other indications, literary texts, and even fragments of texts, also reveal the existence or development of certain techniques that people could use to frame events or issues. One of these (literary) techniques was the fake eyewitness account of fictitious performances, a mode of disinformation which, if considered in the context of the use of theatrical means, reflects the importance of such performances in the making of events and issues.

Moser's contribution emphasizes three important considerations for the study of the role of literary texts and codes in the early modern process of opinion-formation. First, controversial events and issues became more visible through the interplay of rituals, ceremonies, the printing press, performances and manuscripts, with the various media having a mutual multiplier effect: theatrical performances highlighting ceremonies, printed and manuscript pamphlets spreading the news of these ceremonies and performances, as well as framing them for distant audiences. Secondly, like many other pieces of evidence in this volume, the fragment discussed by Moser clearly points to the ways in which early modern societies were also defined by the creation of international 'issues'. What happened on the international stage, and what was being discussed elsewhere, generated local responses, and only in doing so could issues become truly appropriated by international audiences. Thirdly, Moser's argument also stresses once more how all-pervasive literary techniques were in the shaping of early modern issues.

The case of the Dutch fragment linking two major issues of the early seventeenth century Protestant cause, the fate of the Winter King and the Spanish Match, raises many questions about the aim of writing such an account, about the relationship and interplay between fact and fiction, and about the status of the text in a wider public exchange of news and views. Exactly how the traces of early modern literary culture (mainly manuscript and printed texts) can be used in public opinion 
research is thus dealt with most accurately in Moser's contribution. Even though the manuscript leaflet may not have been intended for intervention in the process of opinion-formation, it can still be of major interest to our research, for it reveals, at the very least, the interest of one member of society in an international issue and his attempt to deal with this issue. The fact that the extrapolation of such an individual expression into a more generally held opinion needs extreme care has already been expressed in this epilogue. Moser's contribution shows which questions can be raised to study such a source, and how we can become interlocutors of texts that represent only one view and have a problematic status, in order to elicit interesting data about the process of public opinion-formation. Moser, to some extent arguing against Groenland's concerns about the possibility of constructing a plausible context, shows that even the most fragmented products of literary culture can be turned into revealing sources for the study of the early modern public process of opinion-formation if studied with the utmost care, a thorough knowledge of the issues at stake and the courage to use informed speculation.

\section{VII: LITERARY CULTURE AND PUBLIC OPINION MAKING}

Literary culture then, in whatever way we use the concept and however broadly or narrowly we define the term, should be taken into consideration in historical discussions on the early modern process of public opinion formation and in 'making publics'. So in what way were early modern literary culture and public opinion-formation related, and how did they interact with each other?

Literary texts could air specific opinions and so, as trendsetters, put specific matters on the agenda or, as followers of a trend, put a given consensus into words in specific circles. A literary work could reflect the opinion of a single individual or a small group, and at the same time claim to represent the opinion of a larger group or community (the mouthpiece function). In the early modern Low Countries, literary culture was one of the forces in creating local, regional and supra-regional networks of rhetoricians, humanists, printers and booksellers through which authors could readily disseminate literary works. Literary works were written and read, but above all spoken and heard, performed and watched. Sometimes this occurred in consultation with local or supra-local authorities, but often independently of 
them as well. The rhetoricians sometimes acted as representatives of the local community, sponsored by the local government, and they actively contributed by producing plays, ballades and tableaux vivants at joyous entries of princes or local lords; however, they were just as likely to express direct or indirect criticism (especially in songs and ballades) of the government, the church and its representatives, the community, and dominant beliefs, religious or otherwise.

The way in which an opinion is expressed (and the level of literary encoding applied) affects the research method of the historian. The stronger the literary encoding, the more the creation of a literary work requires mental effort, skill and knowledge, for example, of other literary texts, which means that the opinions it contains-a text can of course express or confront various opinions-are shaped, refined, and altered during the creative process. Literary texts can open minds to many possibilities via various channels for change or stabilization. They could do so by means of their content, but sometimes the writing and publishing of a literary work could in itself be a statement. In the early seventeenth century, a time when the Jesuits in France were regarded as too critical as intellectuals, and their freedom was restricted, the French Jesuit Nicolas Caussin wrote his Latin plays about biblical subjects and the lives of the saints, an act which demonstrated the vitality of his order. ${ }^{17}$

Literary texts informed public opinion in another way too. They offered various narrative strategies, rhetorical devices and basic plots through which events could be narrated and interpreted. ${ }^{18}$ In other words, they provided an arsenal of media techniques and repertoires (allegory, dispute, conversation and oration) which could, and was, deployed to influence public debate. Literary culture could stimulate people, including those without official authority in the public sphere, to follow an author's example and so promote and also spread their views by applying literary techniques and targeting an interested audience. Through the use of dialogue and debating techniques, many early modern literary works also made the main themes and arguments of current debates accessible to larger audiences. Literary

\footnotetext{
17 See Chevalier, 'Le châtiment de la démesure: les tragédies bibliques de Nicolas Caussin' and Valentin, Les jésuites et le théâtre (1554-1680), pp. 489-95.

${ }^{18}$ See Fox, 'Rumour, News and Popular Political Opinion', who points to the impact of basic plots disseminated through popular literature on the political imagination of the British public.
} 
culture can be seen as a breeding ground for ideas in the sense that in early modern texts boundaries were often explored and regularly overstepped. Authors of literary texts often experimented with different forms and viewpoints, while ideas from other circles or other regions were adopted into and adapted for the local context. Conversely, local voices could be adapted for inclusion in Latin texts aimed at an international audience.

In early modern society the link between social debates and the implementation of proposals supported by the population was far from self-evident. It would, however, be useful to carry out systematic research into the precise influence of public issues and debates on the course taken by the authorities and on trends in, for example, lifestyle or social campaigns among the population as a whole. Research topics which come to mind are: How often did themes from public debate and the arguments it generated become the focus of decision-making and to what effect? What was the role of the media and of opinion makers? How much space did society offer for people to propound dissenting and critical ideas? Did public opinion have any authority as such? What attitude did the authorities adopt within the public debate and on what did that attitude depend? Which groups in the population were actively involved in public issues and debates, thereby helping to shape them? Did that involvement lead to both short-term and lasting effects on the cohesion and degree of the organization of society? Did issues and debates deal with real problems or was there a significant amount of exaggeration and hype, whether conscious or unconscious? How well or how badly informed were the people involved, and what impact did this have on their role? How long did public debates last and how did they come to a close? What were the effects on the course of such debates of social movements, interest groups, lobby and pressure groups, the media and opinion leaders?

The importance of literary sources in the study of public opinion, then, is that they represent particular modes of dealing with public issues. We might be inclined to think of public opinion in relation to current contemporary political, economic or religious issues that dominate the talk of the town. However, Groenland warns that literary texts also deal with moral values and norms to such an extent that literary form and moral content were inseparably intertwined. Thus more generally held and less controversial moral opinions could be applied in certain circumstances to deal with particular topical matters. Of 
course, as Moser and others in this volume argue, the mimetic, representative character of literary texts is problematic. Literature does not 'present' things in a straightforward manner; instead we observe 'the world' in the literary work through the eyes of the author or, rather, through the eyes of the narrator(s) and/or character(s). Literature as such moulds the world as experienced and perceived by the author into an artefact, the process known as 'representation'. But it is also true that 'representation' of public opinion reveals something about the way the author-again, one voice in a debate-thought about that opinion or those opinions, even though he may well abstract from 'reality' to a more general notion for 'the eternal prevails over the moment' ('eeuwig gaet voor oogenblick') as Vondel wrote in a consolatory poem about the death of his son Constantijn. In such instances authors may well expect their audiences or readership to apply general notions of how to react or behave in certain circumstances to specific situations. In a larger sense, literary culture urged the public or readership to develop a discerning and critical mind, providing people with models of thought to deal with the world around them.

The study of early modern public opinion is a complex field which calls for the cooperation of historians of art, literature and books as well as social, cultural, intellectual and political historians. It offers a unique possibility of making the methods of these branches of historical studies join forces. In the study of early modern public opinion, the Low Countries are a special case because of the high level of organization that can be compared to other countries such as England, France, Spain, Italy and Germany, where different complexities seem to be in place. We hope that the results of these investigations will contribute to the international debate about the formation of early modern public opinion. If insights gained from the study of public opinion and literary culture in the Low Countries and surrounding regions are compared, this will further our understanding of an important factor in the development of society. 



\section{BIBLIOGRAPHY}

Abrams, Meyer H., and Geoffrey H. Harpham, A Glossary of Literary Terms (Boston: Wadsworth Cengage Learning, 2005).

Agulhon, Maurice, Le cercle dans la France bourgeoise 1810-1848: Étude d'une mutation de sociabilité (Paris: École des hautes études en sciences sociales, 1977).

Akerboom, Dick, and Marcel Gielis, "'A New Song Shall Begin Here...”: The Martyrdom of Luther's Followers among Antwerp's Augustinians on July 1, 1523 and Luther's Response', Johan Leemans and Jürgen Mettepenningen (ed.), More than a Memory: The Discourse of Martyrdom and the Construction of Christian Identity in the History of Christianity (Leuven, etc.: Peeters, 2005), pp. 243-70.

Alonso Hernández, J.L. (ed.), Spaanse letterkunde: Overzicht van de Spaanse letterkunde vanaf de middeleeuwen tot heden (Utrecht: Atrium, 1993).

Anselment, Raymond A., Loyalist Resolve: Patient Fortitude in the English Civil War (Newark: University of Delaware Press, 1988).

Arblaster, Paul, " "Dat de boecken vrij sullen wesen": Private Profit, Public Utility and Secrets of State in the Seventeenth-century Habsburg Netherlands', Joop Koopmans (ed.), News and Politics in Early Modern Europe (1500-1800) (Leuven: Peeters, 2005) (Groningen studies in cultural change, 13), pp. 79-95.

Aristotle, Poetics, transl. by W. Hamilton Fyfe (Cambridge, Mass.: Harvard University Press; London: William Heinemann, 1932).

Arnade, Peter, Beggars, Iconoclasts, and Civic Patriots: The Political Culture of the Dutch Revolt (Ithaca, N.Y., etc., Cornell University Press, 2008).

Atherton, Herbert M., Political Prints in the Age of Hogarth: A Study of the Ideographic Representation of Politics (Oxford: Clarendon Press, 1974).

Barthes, Roland, 'The Death of the Author', idem, Image music text, ed. Stephen Heath (London: Fontana, 1977), pp. 142-48.

Baudet, G.H., "'In beweging bewogen": Maatschappelijke invloed van het geestelijk leven in Alphen aan den Rijn', [P. Leeflang a.o. (eds)], In den Rijn-Vaart der Volkeren: Lezingen uitgesproken ter gelegenheid van het 50-jarig bestaan van de Historische Vereniging Alphen aan den Rijn (Alphen aan den Rijn: Historische Vereniging Alphen aan den Rijn and Stichting Koster Service Schrift, 1998), pp. 101-33.

Baudin, M., 'The People in Seventeenth-Century French Tragedy', Modern Language Notes, 52 (1937), pp. 475-81.

Baudius, Dominicus, Epicedium dictum honori Jacobi Arminii (Leiden: A. Clouck, 1609).

Bautz, Friedrich Wilhelm (ed.), Biographisch-bibliographisches Kirchenlexikon (Hamm: Bautz, 1970- [...]).

Bawcutt, N.W., 'A Crisis of Laudian Censorship: Nicholas and John Okes and the Publication of Sales' An introduction to a devout life in 1637', The Library: A magazine of bibliography and literature, 1 (2000), pp. 403-38.

Beck, David, Spiegel van mijn leven: Een Haags dagboek uit 1624, ed. Sv. E. Veldhuijzen (Hilversum: Verloren, 1993).

Beer, Frances, Women and Mystical Experience in the Middle Ages (Woodbridge: Boydel Press, 1992).

Bellany, Alastair, and McRae, Andrew (eds), 'Early Stuart Libels: An Edition of Poetry from Manuscript Sources', Early Modern Literary Studies Text Series I (2005). http://purl.oclc.org/emls/texts/libels/.

Berghaus, Günter, Die Aufnahme der englischen Revolution in Deutschland 16401669 (Wiesbaden: Harrassowitz, 1989). 
Bertius, Petrus, Oratio in obitum Jacobi Arminii (Leiden: J.J. Paets, 1609).

Billig, Michael, Ideology and Opinions (London, etc.: Sage, 1991).

Blaak, Jeroen, Geletterde levens: Dagelijks leven en schrijven in de vroegmoderne tijd in Nederland 1624-1770 (Hilversum: Verloren, 2004).

Blockmans, Wim, "'Fondans en melencolie de povreté": Leven en werken in Brugge 1482-1584', Maximiliaan P.J. Martens (ed.), Brugge en de Renaissance: Van Memling tot Pourbus (Brugge: Stichting Kunstboek/Ludion, 1998), pp. 26-32.

Bloemendal, Jan, 'König von Gottes Gnaden? Der gute und der böse Monarch auf der frühmodernen Bühne in den Niederlanden bis ca. 1625 anhand der Davidspiele', Bart A.M. Ramakers, Christel Meier-Staubach, and Heinz Meyer (eds), Akteure und Aktionen: Figuren und Handlungstypen im Drama der frühen Neuzeit (Münster: Rhema, 2008), pp. 289-319.

_-, 'Mon Dieu, mon Dieu...: Aspecten van literatuur en werkelijkheid in Daniel Heinsius, Auriacus, sive Libertas saucia (1602)', Bulletin: Geschiedenis, Kunst en Cultuur (1996), pp. 91-107.

— - 'Receptions and Impact: Early Modern Latin Drama, its Effect on the Audience and its Role in Forming Public Opinion', Bloemendal and Ford, Neo-Latin Drama, pp. 7-22.

_. 'Rond de Vader des Vaderlands: Oranje, Heinsius en Leiden', Karl Enenkel, Sjaak Onderdelinden en Paul J. Smith (eds), "Typisch Nederlands": De Nederlandse identiteit in de letterkunde (Voorthuizen: Florivallis, 1999), pp. 10-25.

_- 'Transfer and Integration of Latin and Vernacular Dramas in the Early Modern Period: The Case of Everyman, Elckerlijc, Homulus, and Hecastus', Transfer and Integration, ed. by Sophie Levie and Els Andringa. Special issue of Arcadia, 44 (2009), pp. 274-88.

_ ' 'Willem van Oranje: Een Hercules op Leidse planken', De zeventiende eeuw, 10 (1994), pp. 159-67.

- , and Philip J. Ford (eds), Neo-Latin Drama: Forms, Functions, Receptions (Hildesheim, Zurich and New York: Olms, 2008) (Noctes Neolatinae-Neo-Latin Texts and Studies, 9).

Boden, Gezin: von Mansfeld/de Montmorency-Nivelles(F1205048179). http://stamboomboden.com/familygroup.php? familyID=F1205048179\&tree=1 (accessed 15 februari 2009).

Boer, Connie de and Harm 't Hart, Publieke opinie (Amsterdam: Boom, 2007).

Boer, Willem A. den, Duplex Amor Dei: Contextuele karakteristiek van de theologie van Jacobus Arminius (1559-1609) (Apeldoorn: Instituut voor Reformatieonderzoek, 2008) (Doctoral thesis Apeldoorn).

Bonney, Richard. 'The European Reaction to the Trial and Execution of Charles I', Jason Peacey (ed.), The Regicides and the Execution of Charles I (Houndmills: Palgrave, 2001), pp. 247-79.

Boone, Marc, “"In den beginne was het woord": De vroege groei van "parlementen" in de middeleeuwse vorstendommen der Nederlanden', Bijdragen en Mededelingen voor de Geschiedenis van Nederland, 120 (2005), pp. 338-61.

Booth, Waine C., The Rhetoric of Fiction (Chicago, London: University of Chicago Press, $\left.{ }^{2} 1983\right)$.

Bosch, Leonardus J.M., Petrus Bertius 1565-1629 (Meppel: s.n., 1979) (Doctoral thesis Nijmegen).

Bouza, Fernando, Corre manuscrito: Una historia cultural del Siglo de Oro (Madrid: Marcial Pons, 2001).

Branden, Frans J.P. van den, Anna Bijns: Haar leven, hare werken, haar tijd, 14931575 (Antwerpen: Resseler, 1911).

Brandt, Geraerd, Historie der Reformatie (Amsterdam: Jan Rieuwertsz., Hendrik en Dirk Boom, 1677).

Braunmuller, A.R., “"To the Globe I rowed”: John Holles sees A Game at Chess', English Literary Renaissance, 20 (1990), pp. 340-56. 
Brettschneider, Frank, Öffentliche Meinung und Politik: Eine empirische Studie zur Responsivität des Deutschen Bundestages zwischen 1949 und 1990 (Opladen: Westdeutscher Verlag, 1995).

Briggs, Asa and Peter Burke, A Social History of the Media: From Gutenberg to the Internet (Cambridge: Polity, 2002).

Brillenburg Wurth, Kiene and Ann Rigney (eds), Het leven van teksten: Een inleiding tot de literatuurwetenschap (Amsterdam: Amsterdam University Press, 2006).

Bruaene, Anne-Laure Van, "A wonderful triumfe, for the wynnyng of a pryse": Guilds, Ritual, Theater, and the Urban Network in the Southern Low Countries, ca. 1450-1650', Renaissance Quarterly, 65 (2006), pp. 374-405.

- 'Printing Plays: The publication of the Ghent plays of 1539 and the reaction of the authorities', Dutch Crossing, 24 (2000), pp. 265-84.

_- Om beters wille: Rederijkerskamers en de stedelijke cultuur in de Zuidelijke Nederlanden (1400-1650) (Amsterdam: Amsterdam University Press, 2008) (Doctoral thesis Ghent, 2004).

Brugmans, Hajo, Briefwechsel des Ubbo Emmius (Den Haag: Nijhoff, 1911-1923).

Bruin, Guido de, Geheimhouding en verraad: De geheimhouding van staatszaken ten tijde van de Republiek (1600-1750) ('s-Gravenhage: Sdu, 1991).

Calhoun, Craig (ed.), Habermas and the Public Sphere (Cambridge and London: MIT Press, 1993).

Capp, Bernard, When Gossips Meet: Women, Family, and Neighbourhood in Early Modern England (Oxford, Oxford University Press, 2003).

Cartwright, William, Comedies, tragi-comedies, with other poems, by Mr William Cartwright (London: Humphrey Moseley, 1651).

_, Plays and poems, ed. by G. Blakemore Evans (Madison: University of Wisconsin Press, 1951).

Castelein, Mathijs de, De const van rhetoriken (Oudenaarde: Theater Pax Vobis, 1986) (first ed. Gent 1555). http://www.dbnl.org/tekst/cast005cons01_01/index.htm (25 April 2007).

Chartier, Roger, 'Copied Onely by the Eare', Roger Chartier, Publishing Drama in Early Modern Europe (London: The British Library Publishing Division 1999), pp. 28-50.

Chevalier, Jean-Frédéric, 'Le châtiment de la démesure: Les tragédies bibliques de Nicolas Caussin', Bloemendal and Ford, Neo-Latin Drama, pp. 77-92.

Clerc, Jean le, Epistolario I (1679-1689) ed. by M. Sina (Firenze: Olschki, 1987).

Cogswell, Thomas, Blessed Revolution: English Politics and the Coming of War, 16211624 (Cambridge: Cambridge University Press, 1989).

Coigneau, Dirk (ed.), Mariken van Nieumeghen (Hilversum: Verloren, 1996).

_-, 'Rederijkersliteratuur', Marijke Spies (ed.), Historische letterkunde: Facetten van vakbeoefening (Groningen: Wolters-Noordhoff, 1984), pp.35-57. Also on www. dbnl.nl.

- Refreinen in het zotte bij de rederijkers (Gent: Secretariaat van de Koninklijke Academie voor Nederlandse taal- en letterkunde, 1980), 3 vols (Koninklijke Vlaamse Academie voor Taal- en Letterkunde, VIe reeks, nr. 111).

Coldiron, Anne, 'Public Sphere / Contact Zone: Habermas, Early Print, and Verse Translation', Criticism, 46 (2004), pp. 207-22.

Coleridge, Samuel Taylor, The literary remains, ed. by Henry Nelson Coleridge. http:// www.gutenberg.org/etext/8956.

Converse, Jean, Survey Research in the United States: Roots and Emergence, 1890-1960 (Berkeley: University of California Press, 1987).

Converse, Ph.E., 'The Nature of Belief Systems in Mass Publics', David E. Apter (ed.), Ideology and Discontent (New York: The Free press of Glencoe, 1964), pp. 206-61.

Cowan, Alexander, 'Gossip and Street Culture in Early Modern Venice', Journal of Early Modern History, 12 (2008), pp. 313-33. 
Crespi, Irving, The Public Opinion Process: How the People Speak (Mahwah, New Jersey: Lawrence Erlbaum, 1997).

Cruickshank, D.W., 'Calderón's Amor, honor y poder and the Prince of Wales, 1623', Bulletin of Hispanic Studies, 77 (2000), pp. 75-99.

Cust, Richard, 'News and Politics in Early Seventeenth-Century England', Past and Present, 112 (1986), pp. 60-90.

Darby, Trudi L., 'The Black Knight's Festival Book? Thomas Middleton's A Game at Chess', Samson, The Spanish Match, pp. 173-87.

Darnton, Robert, 'An Early Information Society: News and the Media in EighteenthCentury Paris', The American Historical Review, 105 (2002), pp. 1-35.

Demoed, Verena E.M., 'Wie van gevaar houdt, moet dat met de dood bekopen.' De opiniërende strategieën van de toneelschrijver Gulielmus Gnapheus (1493-1568) (s.l.: s.n., 2011). Doctoral thesis Amsterdam.

Dene, Eduard de, Testament rhetoricael, ed. by W. Waterschoot en D. Coigneau, 3 vols, Jaarboek 'De Fonteine', 26, 28 and 30 (1976-1980).

Deursen, Arie Th. van, Bavianen en Slijkgeuzen: Kerk en kerkvolk ten tijde van Maurits en Oldebarnevelt (Assen: Van Gorcum, 1974) (Van Gorcum's historische bibliotheek, 92).

_-, Maurits van Nassau, 1567-1625: De winnaar die faalde (Amsterdam: Bakker, 2000).

Dijkhuizen, Jan-Frans van, and Helmer Helmers, 'So Shall the World Go On: Politics and Religion in Vondel and Milton', Jan Bloemendal, Frans-Willem Korsten, and Stefan van der Lecq (eds), Vondel: Dutch Dramatist of the Golden Age (Leiden: Brill, 2011) [Forthcoming].

Dingemanse, Clazina, Rap van tong, scherp van pen: Literaire discussiecultuur in Nederlandse praatjespamfletten (circa 1600-1750) (Hilversum: Verloren, 2008) (Doctoral thesis Utrecht).

Dinkelaar, Henk, Wilde, Frits de, and Zwieten, Jan van (eds), Volk op viersprong: Acht verhalen over het verleden, om het heden van Alphen te verstaan ([Alphen aan den Rijn]: Stichting Rijnlandse Historiën, 1988).

Dis, Leendert M. van, Reformatorische rederijkersspelen uit de eerste helft van de zestiende eeuw (Haarlem: Vijlbrief, 1937) (Doctoral thesis Utrecht).

Dixhoorn, Arjan van, 'Chambers of Rhetoric: Performative Culture and Literary Sociability in the Early Modern Northern Netherlands', Van Dixhoorn and Speakman Sutch, The Reach of the Republic of Letters, pp. 119-57.

_ - 'Liefhebbers van de redekunst: Het Vlaardingse festival van 1616 en de principes van het Hollandse rederijkersleven', Ramakers, Op de Hollandse Parnas, pp. 11-29.

- 'Soorten rederijkers: Rederijkers en hun plaats in het intellectuele veld, 15501650', Dirk Coigneau and Samuel Mareel (eds), Met eigen ogen: De rederijker als dichtend individu (1450-1600) (= Jaarboek 'De Fonteine', 2009), pp. 87-120.

- 'The grain issue of 1565-1566: Policymaking, public opinion, and common good in the Habsburg Netherlands', Anne-Laure Van Bruaene and Elodie LecuppreDesjardin (eds), De bono communi. The discourse and practice of the common good in the European City (13th-16th c.) (Turnhout: Brepols, 2010), pp. 171-204.

_- Lustige geesten: Rederijkers in de Noordelijke Nederlanden (1480-1650) (Amsterdam: Amsterdam University Press, 2009) (Doctoral thesis Amsterdam, 2004).

—, and Susie Speakman Sutch (eds), The Reach of the Republic of Letters: Literary and Learned Societies in Late Medieval and Early Modern Europe, 2 vols (Leiden, Boston: Brill, 2008). Brill's Studies in Intellectual History, 168.

Doudet, Estelle, 'Statuts et figures de la voix satirique dans le théâtre polémique français (XV ${ }^{\mathrm{e}}-\mathrm{XVI}^{\mathrm{e}}$ siècles)', Le Théâtre polémique français $1450-1550$, ed. by Marie Bouhaïk-Gironès, Jelle Koopmans and Katell Lavéant (Rennes: Presses universitaires de Rennes, 2008), pp. 15-29. 
Drewes, J.B., 'Het interpreteren van godsdienstige spelen van zinne', Jaarboek 'De Fonteine', 29 (1978-1979), pp. 5-125. Also www.dbnl.nl (accessed 3 June 2009).

Duccini, Hélène, Faire voir, faire croire: L'Opinion publique sous Louis XIII (Seyssel: Champ Vallon, 2003) (Epoques).

Duits, Henk, 'Horror als voorafje: De "Voorzangk" bij Joan Dullaarts Karel Stuart', Henk Duits, Arie Jan Gelderblom, and Mieke B. Smits-Veldt (eds), Klinkend boeket: Studies over renaissancesonnetten voor Marijke Spies (Hilversum: Verloren, 1994), pp. 113-20.

- Van Bartholomeusnacht tot Bataafse opstand: Studies over de relatie tussen politiek en toneel in het midden van de zeventiende eeuw (Hilversum: Verloren, 1990) (Doctoral thesis Amsterdam).

Duke, Alistair, 'Dissident Propaganda and Political Organization at the Outbreak of the Revolt of the Netherlands', Philip Benedict (ed.), Reformation, Revolt and Civil War in France and the Netherlands 1555-1585 (Amsterdam: Royal Netherlands Academy of Arts and Sciences, 1999), pp. 115-32.

Dunckelmann, Henning, Lokale Öffentlichkeit: Eine gemeindesoziologische Untersuchung (Stuttgart: W. Kohlhammer, 1975).

Duym, Jacob, Het Moordadich Stuck van Balthasar Gerards, ed. by L.F.A. Serrarens and Nicolaas C.H. Wijngaards (Zutphen: Thieme, [1975]). KLP, 218.

Eisenstein, Elizabeth, The Printing Press as an Agent of Change: Communications and Cultural Transformations in early-modern Europe (Cambridge: Cambridge University Press, 1979).

Elias, Johan E., De vroedschap van Amsterdam, 1578-1795 (Amsterdam: Israel, 1963; Haarlem: Loosjes, 1903-1905 $)$.

_- Geschiedenis van het Amsterdamse regentenpatriciaat ('s-Gravenhage: Nijhoff, 1923).

Ellinger, Georg, Geschichte der neulateinischen Literatur Deutschlands im sechzehnten Jahrhundert, III,1 (Berlin: De Gruyter, 1933).

Emmius, Ubbo, Briefwechsel des Ubbo Emmius, ed. by H. Brugmans, 2 vols (Aurich etc.: Dunckmann; Den Haag: Nijhoff, 1911-1923).

Ens, Caspar, Princeps Auriacus, sive Libertas defensa (1599) (De prins van Oranje of de verdediging van de Vrijheid), ed. by Jan Bloemendal and Jan W. Steenbeek (Voorthuizen: Florivallis, 1998).

Erasmus, Desiderius, Opera omnia (Amsterdam: North-Holland Publishing Company; Leiden: Brill, 1969-[...]).

Erné, Benjamin H., 'Anna Bijns en Stevijn: Een briefwisseling in refreinen', Jaarboek 'De Fonteine', 18 (1968) (2nd Series, No. 10), pp. 161-86.

Es, Jan van, Limes en linie: Twintig eeuwen verdedigingswerken tussen de Oude Rijn en de Hollandse IJssel, (Woerden: Stichting Stichts-Hollandsche Bijdragen, 2004) (Stichts-Hollandsche Bijdragen, 31).

Ettinghausen, Henry, 'The Greatest News Story Since the Resurrection? Andrés de Almansa y Mendoza's Coverage of Prince Charles's Spanish Trip', Samson, The Spanish Match, pp. 75-89.

Evers, Wim J.M., Informele openbaarmaking: Een studie naar de massacommunicatieve betekenis van onderlinge gesprekken (Nijmegen: s.n., 1999) (Doctoral thesis Nijmegen).

Eversmann, Peter G.F., 'The Experience of the Theatrical Event', Vicky Ann Cremona et al. (eds), Theatrical Events: Borders, Dynamics, Frames (Amsterdam, New York: Rodopi, 2004), pp. 139-74.

Eyffinger, Arthur, Inventory of the Poetry of Hugo Grotius (Assen: Van Gorcum, 1982). Eysinga, Willem J.M. van, De wording van het Twaalfjarig Bestand van 9 april 1609 (Amsterdam: Noord-Hollandsche Uitgevers Maatschappij, 1959).

Farge, Arlette, Dire et mal dire: L'opinion publique au XVIII siècle (Paris: Éditions du Seuil, 1992). 
—, Subversive Words: Public Opinion in Eighteenth-Century France (Pennsylvania: Polity Press, 1995).

Faulstich, Werner, Medien und Öffentlichkeiten im Mittelalter, 800-1400 (Göttingen: Vandenhoeck \& Ruprecht, 1996).

Faulstich, Werner, Medien zwischen Herrschaft und Revolte: Die Medienkultur der frühen Neuzeit (1400-1700) (Göttingen: Vandenhoeck \& Ruprecht, 1998).

Fishkin, James S., The Voice of the People: Public Opinion and Democracy (New Haven: Yale University Press, 1995).

Floyd H. Allport, 'Toward a Science of Public Opinion', Katz et al., Public Opinion and Propaganda, pp. 51-61.

Foucault, Michel, 'Wat is een auteur?', Barend van Heusden, Wouter Steffelaar \& Peter Zeeman (eds), Literaire cultuur: Tekstboek (Nijmegen: SUN, 2001), pp. 258-77.

Fox, Adam, 'Rumour, News and Popular Political Opinion in Elizabethan and Early Stuart England', Historical Journal, 40 (1997), pp. 597-620.

—, Oral and Literate Culture in England 1500-1700 (Oxford: Clarendon Press, 2000).

- The Spoken Word: Oral culture in Britain 1500-1850 (Manchester and New York: Manchester University Press, 2002).

Fraser, Nancy, 'Rethinking the Public Sphere: A Contribution to the Critique of Actually Existing Democracy', Bruce Robbins (ed.), The Phantom Public Sphere (Minneapolis and London: University of Minnesota Press, 1990), pp. 1-32. Cultural politics, 5 .

Freist, Dagmar, Governed by Opinion: Politics, Religion and the Dynamics of Communication in Stuart London, 1637-1645 (London and New York: Tauris Academic Studies, 1997).

Frijhoff, Willem, Wegen van Evert Willemsz: Een Hollands weeskind op zoek naar zichzelf, 1607-1647 (Nijmegen: SUN, 1995).

Fumerton, Patricia, 'Not Home: Alehouses, Ballads, and the Vagrant Husband in Early Modern England', Journal of Medieval and Early Modern Studies, 32 (2002), pp. 493-518.

Geevers, Liesbeth, Gevallen vazallen: De integratie van Oranje, Egmont en Horn in de Spaans-Habsburgse monarchie (1559-1567) (Amsterdam: Amsterdam University Press, 2008) (Doctoral thesis Amsterdam).

Gelder, Hendrik Enno van, 'Satiren der zestiende-eeuwsche kleine burgerij', OudHolland, 29 (1911), pp. 201-52.

Gelderen, Martin van, The Political Thought of The Dutch Revolt, 1555-1590 (Cambridge, etc.: Cambridge University Press, 1992).

Gemert, Guillaume van, 'Zum Verhältnis neulateinischer und muttersprachlicher Dichtung bei Daniel Heinsius', Eckard Lefèvre and Eckart Schäfer (eds), Daniel Heinsius: Klassischer Philologe und Poet (Tübingen, Gunter Narr Verlag, 2008) (NeoLatina, 13), pp. 297-313.

Gemert, Lia van, 'De Haagsche Broeder-Moord: Oranje ontmaskerd', Literatuur, 1 (1984), pp. 268-76.

Genette, Gérard, Paratexts: Thresholds of Interpretation, transl. by Jane E. Lewin (Cambridge: Cambridge University Press, 1997).

Gerritsen, Johan, 'The Eikon in Holland', S. van der Woude (ed.), Studia bibliographica in honorem Herman de la Fontaine Verwey (Amsterdam: Menno Hertzberger, 1968), pp. 129-43.

Geyl, Pieter, Orange and Stuart (London: Phoenix Press, 2001).

Glasser, T.L., and C.T. Salmon (eds), Public Opinion and the Communication of Consent (New York: Guilford Press, 1995).

Glynn, C.J., R.E. Ostman, and D.G. McDonald, 'Opinions, Perception, and Social Reality', Glasser and Salmon, Public Opinion and the Communication of Consent, pp. 249-77. 
Gnapheus, Guilielmus, [...] Adversus temerariam, ne dicam impiam excommunicationis censuram [...] a quibusdam Academiae Regimontanae apud Prutenos nuper institutae professoribus et concionatoribus ex mera invidia et malignandi libidine in ipsum latam, extemporalis quaedam Antilogia ([s.l.: s.n.], 1551), also in Johannes a Lasco Bibliothek Emden, Sammlung Albert Ritzaeus Hardenberg http://hardenberg .jalb.de [accessed 29 May 2009].

- Tobias ende Lazarus (Emden: Gellius Ctematius, 1557).

- Acolastus (Antwerp: Godfridus Dumaeus, 1529).

_- Acolastus (Antwerp: Joannes Loëus, 1555); also in Johannes a Lasco Bibliothek Emden, Sammlung Albert Ritzaeus Hardenberg http://hardenberg.jalb.de (accessed 29 May 2009).

— - Acolastus, ed. by Johannes Bolte (Berlin: Speyer \& Peters, 1891).

_- Acolastus, ed. by Pieter Minderaa (Zwolle: Tjeenk Willink, 1956).

_- Acolastus: A Latin play of the sixteenth century, ed. by W.E.D. Atkinson (London, Ontario: University of Western Ontario, 1964).

_ - Een troost ende spiegel der siecken ende derghenen die in lijden zijn [...] ([Antwerp]: [s.n.], 1531), Bibliotheca Reformatoria Neerlandica: Geschriften uit den tijd der Hervorming, ed. by Samuel Cramer and F. Pijper, 10 vols (The Hague: Nijhoff, 1903-1914) I, pp. 151-249.

- The comedy of Acolastus. Translated from the Latin of Fullonius by John Palsgrave, ed. by P.L. Carver (London: Milford, Oxford University Press, 1937) (Early English Text Society, 202).

Gnapheus, Hypocrisis (Basel: Barptholomeus Vuesthemerus, 1544; Wittenberg: Johannes Crato, 1564).

—, Morosophus (Gdansk: Franciscus Rhodus, 1541).

Goffin, R. Cullis, The Life and Poems of William Cartwright (Cambridge: s.n., 1918).

González Gutiérrez, Cayo, El Teatro Escolar de los Jesuitas (1555-1640) y Edición de la 'Tragedia de San Hermenegildo' (Oviedo: Universidad de Oviedo Servicio de Publicaciones, 1997).

Goode, Luke, Jürgen Habermas: Democracy and the Public Sphere (London and Ann Arbor: Pluto Press, 2005).

Graft, Catharina C. van de, Middelnederlandsche historieliederen (Epe: Hooiberg, 1904) (Doctoral thesis Amsterdam).

Grafton, Anthony and Lisa Jardine, From Humanism to the Humanities: Education and the liberal arts in fifteenth-and sixteenth-century Europe (Cambridge, Mass.: Duckworth, 1986).

Grijp, Louis P., 'Het Nederlandse lied in de Gouden Eeuw: Het mechanisme van de contrafactuur', Tijdschrift van de Vereniging voor Nederlandse Muziekgeschiedenis, 42 (1992), pp. 141-43.

_- Het Nederlandse lied in de Gouden Eeuw: Het mechanisme van de contrafactuur (Amsterdam 1991). Dissertation Utrecht.

Groenland, Juliette A., 'Tijdloze geschiedenislessen: Antieke geschiedschrijvers in het vroeg-humanistische studieprogramma (1400-1520)', Lampas, 37 (2004), pp. 172-78.

_ - 'Toneel als pamflet? De Princeps Auriacus sive Libertas Defensa (1599) van Caspar Ens', De zeventiende eeuw, 25 (2009), pp. 26-38.

- 'Predicting the Present: Final Prophesies in Latin and Dutch History Plays in the Early Years of the Dutch Republic', Christel Meier, Bart A.M. Ramakers, Harmut Beyer (eds), Akteure und Aktionen: Figuren und Handlungstypen im Drama der Frühen Neuzeit (Münster: Rhema Verlag, 2008), pp. 461-83.

— ' 'The deadly earnest of history plays', Bloemendal and Ford, Neo-Latin Drama: Forms, Functions, Receptions, pp. 23-33.

Groenveld, Simon, De Prins voor Amsterdam (Bussum: Van Dishoeck, 1967).

—, Verlopend getij: De Nederlandse Republiek en de Engelse burgeroorlog 1640-1646

(Dieren: De Bataafsche Leeuw, 1984). 
Grootens, Petrus L.M., Dominicus Baudius: Een levensschets uit het Leidse humanistenmilieu, 1561-1613 (Nijmegen: Dekker and Van de Vegt, 1942) (Doctoral thesis Nijmegen).

Grosheide, Daniël, Cromwell naar het oordeel van zijn Nederlandse tijdgenoten (Amsterdam: Noord-Hollandse Uitgevers Maatschappij, 1951).

Grotius, Hugo, Briefwisseling van Hugo Grotius, ed. by P.C. Molhuysen a.o. (Den Haag: Nijhoff, 1928-2001) 17 vols.

- De Dichtwerken van Hugo Grotius (The Poetry of Hugo Grotius) ed. by B.L. Meulenbroek, Arthur C. Eyffinger, Edwin Rabbie (Assen: van Gorcum, 1970-[...]).

_- Meletius sive de iis quae inter christianos convenient epistola, ed. by G.H.M. Posthumus Meyjes (Leiden, etc.: Brill, 1988) (Studies in the History of Christian Thought, 40).

—, Ordinum Hollandiae ac Westfrisiae pietas (1613), ed. by Edwin Rabbie (Leiden etc.: Brill, 1995) (Studies in the History of Christian Thought, 66).

Habermas, Jürgen, The Structural Transformation of the Public Sphere: An Inquiry into a Category of Bourgeois Society (Cambridge: Polity Press 1989); translation of Strukturwandel der Öffentlichkeit. Untersuchingen zu einer Kategorie der bürgerlichen Gesellschaft (Darmstadt, etc.: Luchterhand, 1962).

Hadfield, Andrew, Literature, Politics and National Identity: Reformation to Renaissance (Cambridge: Cambridge University Press, 1994).

Haecht, Godevaert van, De kroniek van Godevaert van Haecht over de troebelen van 1565 tot 1574 te Antwerpen en elders, ed. by Robert Van Roosbroeck (Antwerp: De Sikkel, 1929).

Haks, Donald, 'De Franse tirannie: De verbeelding van een massamoord', Henk van Nierop a.o. (eds), Romeyn de Hooghe: De verbeelding van de late Gouden Eeuw (Zwolle: Waanders, 2008), pp. 86-99.

Harline, Craig E., Pamphlets, Printing and Political Culture in the Early Dutch Republic (Dordrecht: Martinus Nijhoff; Boston, Lancaster: Springer, 1987).

Heijting, W., De Catechismi en confessies in de Nederlandse Reformatie tot 1585. The Catechisms and Confessions of Faith in the Dutch Reformation to 1585, 2 vols (Nieuwkoop: De Graaf Publishers, 1989) (Bibliotheca Bibliographica Neerlandica, 27).

Heinsius, Daniel, Auriacus sive Libertas saucia (1602), ed. Jan Bloemendal, 2 vols (Voorthuizen: Florivallis, 1997) (Doctoral thesis Utrecht).

Helander, Hans, Neo-Latin Literature in Sweden in the Period 1620-1720: Stylistics, Vocabulary and Characteristic Ideas (Uppsala: Uppsala Universitet, 2004) (Acta Universitatis Upsaliensis; Studia latina Upsaliensia, 29).

Hellinga, Lotte, Alistair Duke, Jacob Harskamp, and Theo Hermans (eds), The Bookshop of the World: The Role of the Low Countries in the Book Trade 1473-1941 ('t Goy-Houten: Hes \& De Graaf Publishers, 2001).

Herbst, S., 'On the Disappearance of Groups: 19th- and Early 20th-Century Conceptions of Public Opinion', Glasser and Salmon, Public Opinion and the Communication of Consent, pp. 89-104.

—, Reading Public Opinion: How Political Actors View the Democratic Process (Chicago: University of Chicago Press, 1998).

Heusden, Barend van, 'Omhelsd door de retorica: Over lessen in literatuur van Frans Willem Korsten', Spiegel der Letteren, 46 (2004), pp. 77-92.

Hillerbrand, H.J. (ed.), The Oxford Encyclopedia of the Reformation, 4 vols (New York Oxford: Oxford University Press, 1996).

Hollaar, Henk, De Rotterdamse spelen van 1561: Een Hollandse toneelcompetitie met politieke lading (Delft: Eburon, 2006) (Doctoral thesis Amsterdam).

- Van weelde en andere plagen: Rotterdamse refereynen (1561) peilen publieke opinie ([Delft: Eburon], 2007.

Hooft, Pieter Cornelisz, Nederlandse Historiën: Een keuze uit het grote verhaal van de Nederlandse Opstand, ed. by Frank van Gestel, Eddy Grootes and Jan de Jongste (Amsterdam: Bert Bakker, 2007). 
Hooft, Pieter Corneliszoon, Neederlandsche Histooriën (Amsterdam: Ian Iacobsz Schipper, 1642).

Hora Siccama, J.H., Aantekeningen en verbeteringen op het (...) register op de journalen van Constantijn Huygens den zoon (Amsterdam: Johannes Müller, 1915).

Horodowich, Elizabeth, 'The gossiping tongue: Oral Networks, Public Life and Political Culture in Early Modern Venice', Renaissance Studies, 19 (2005), 1, pp. 22-45.

Howard-Hill, T.H., 'The unique eye-witness report of Middleton's A Game at Chess', The Review of English Studies, 47 (1991), pp. 168-78.

Hubatsch, Walther, Geschichte der evangelischen Kirche Ostpreussens, 3 vols (Göttingen: Vandenhoeck \& Ruprecht, 1968).

Huizinga, Johan, Herfsttij der Middeleeuwen (Haarlem: s.n., 1919) published in English as The Waning of the Middle Ages (London: Edward Arnold \& Co, 1924).

Huls, Jos A., 'Seuen manieren van minnen' van Beatrijs van Nazareth: het mystieke proces en mystagogische implicaties (Leuven: Peeters, 2002) (Doctoral thesis Nijmegen).

Hummelen, Willem M.H. and Geert R.W. Dibbets (eds), Het Cooren (1565) van Lauris Jansz., factor van de Haarlemse rederijkerskamer De Wijngaertrancken (Zutphen: Thieme, s.a.) (KLP, 225).

Hummelen, Willem M.H. De sinnekens in het rederijkersdrama (Groningen: Wolters, 1958) (Doctoral thesis Groningen), also www.dbnl.nl (accessed 29 May 2009).

Hummelen, Wim, "Het tableau vivant, de "toog", in de toneelspelen van de rederijkers', Tijdschrift voor Nederlandse taal- en letterkunde, 108 (1992), pp. 193-222.

Hüsken, Wim N.M., 'Kroniek van het toneel in Brugge (1468-1556)', Verslagen en mededelingen van de Koninklijke Academie voor Nederlandse Taal- en Letterkunde (Gent: Koninklijke Academie voor Taal- en Letterkunde, 1992), pp. 219-52.

Hüsken, Wim N.M., 'Politics and Drama: The City of Bruges as Organizer of Drama Festivals', Allan E. Knight (ed.), The Stage as Mirror: Civic Theatre in Late Medieval Europe (Cambridge etc.: Brewer, 1997), pp. 165-87.

- 'The Fool as Social Critic: The Case of the Dutch Rhetoricians' Drama', Clifford Davidson (ed.), Fools and Folly (Kalamazoo: Medieval Institute Publications, Western Michigan University, 1996) (Early Drama, Art and Music Monograph Series, 22), pp. 112-45.

- De spelen van Cornelis Everaert (Hilversum: Verloren, 2005).

Israel, Jonathan I., The Dutch Republic: Its Rise, Greatness, and Fall, 1477-1806 (Oxford: Clarendon Press, 1995).

Jacobs, Anne E. (ed.), J. Six van Chandelier. Gedichten. 2 Vols (Amsterdam: KNAW, 1991).

Jäger, Wolfgang, Öffentlichkeit und Parlamentarismus: Eine Kritik an Jürgen Habermas (Stuttgart: Kohlhammer, 1973).

Joldersma, Hermina (ed.), 'Het Antwerps liedboek': A Critical Edition ([Ann Arbor: University Microfilm International], 1982) (Doctoral thesis Princeton).

Jong, K.K. de, "'Noit heeft de Zon gruwelijker daat beschouwt": Joan Dullaarts visie op de terechtstelling van Karel Stuart', Henk Duits, Arie Jan Gelderblom and M.B. Smits-Veldt (eds), Eer is het lof des deuchts: Opstellen over renaissance en classicisme aangeboden aan dr. Fokke Veenstra (Amsterdam: De Bataafsche Leeuw, 1986), pp. 162-68.

Julius, P. OFMCap, 'Anna Bijns en Bonaventura', De Nieuwe taalgids, 59 (1966), pp. 396-401.

Kaase, M., and B. Pfetsch, 'Umfrageforschung und Demokratie: Analysen zu einem schwierigen Verhältnis', H.D. Klingemann and F. Neidhardt (eds), Zur Zukunft der Demokratie: Herausforderungen im Zeitalter der Globalisierung (Berlin: Edition Sigma, 2000), pp. 153-83.

Katz, Daniel, a.o. (eds), Public Opinion and Propaganda: A Book of Readings edited for the Society for the Psychological Study of Social Issues (New York, Chicago, and San Francisco: Dryden press, etc., 1954). 
Katz, Elihu and Paul F. Lazarsfeld, Personal Influence: The Part Played by People in the Flow of Mass Communications (Glencoe, Ill.: Free Press, 1955).

Kay, Sarah, 'Grafting the Knowledge Community: The purposes of verse in the Breviari d'amor of Matfre Ermengaud', Neophilologus, 91 (2007), pp. 361-73.

Kernkamp, Gerhard W., Prins Willem II, 1626-1650 (Rotterdam: Ad. Donker, 1978).

Kerrigan, John, 'Revenge tragedy revisited, 1649-1683', On Shakespeare and Early Modern Literature (Oxford: Oxford University Press, 2001), pp. 230-54.

Keßler, Judith, 'Anna in veelvoud: De relatie tussen auteursrepresentatie en interpretatie in de poëzie van Anna Bijns', Dirk Coigneau and Samuel Mareel (eds), Met eigen ogen: De rederijker als dichtend individu (1450-1600) (= Jaarboek 'De Fonteine', 2008), pp. 45-68.

_ - 'Wie is Cornelis Damasz? Nieuws over handschrift Brussel, KB, II 270', Nederlandse Letterkunde, 12 (2007), pp. 94-117.

- - and Johan Oosterman (eds), Schoon ende suverlijc boecxken inhoudende veel constige refereinen (Refereinen 1528). http://www.dbnl.nl/tekst/bijn003refe01_01/index. htm (June 2007).

_- (eds), Seer scoon ende suyver boeck, verclarende die mogentheyt Gods, ende Christus ghenade, over die sondighe menschen (Refereinen 1567). http://www.dbnl.nl/ tekst/bijn003refe03_01/index.htm (Nov. 2007).

-, (eds), Tweede boeck vol schoone ende constighe refereynen (Refereinen 1548). http://www.dbnl.nl/tekst/bijn003refe02_01/index.htm (Nov. 2007).

Keuning, Johannes, Petrus Plancius: Theoloog en Geograaf, 1552-1622 (Amsterdam: Van Kampen, 1946).

Knuttel, Willem P.C., Catalogus van de pamfletten-verzameling berustende in de Koninklijke Bibliotheek (Utrecht: HES Publishers, 1978). ['s-Gravenhage: Koninklijke Bibliotheek, 1889-19201].

_- Verboden boeken in de Republiek der Vereenigde Nederlanden (Den Haag: Martinus Nijhoff, 1914).

Kohl, Benjamin G., 'Humanism and Education', in Albert Rabil Jr (ed.), Renaissance Humanism: Foundations, Forms and Legacy, vol. 3: Humanism and the Disciplines (Philadelphia: University of Pennsylvania Press, 1988), pp. 5-22.

Komrij, Gerrit (ed.), De Nederlandse poëzie van de twaalfde tot en met de zestiende eeuw in duizend en enige bladzijden (Amsterdam: Bert Bakker, 1994).

Könneker, Barbara, Die Deutsche Literatur der Reformationszeit: Kommentar zu einer Epoche (Munich: Winkler, 1975).

Koppenol, Johan, 'Jacob Duym en de Leidse rederijkers'. http://www.neerlandistiek .nl/?000010.

— Leids heelal: Het Loterijspel (1596) van Jan van Hout (Hilversum: Verloren, 1998) (Doctoral thesis Leiden).

Korsten, Frans-Willem, Lessen in literatuur (Nijmegen: Van Tilt, 2002).

Kossmann, F.K.H., 'Refereynen en liedekens op losse bladen', Het Boek: Tijdschrift voor boek- en bibliotheekwezen, Tweede reeks, 15 (1926), pp. 49-72.

Kruif, José de, Marijke Meijer Drees, and Jeroen Salman (eds), Het lange leven van het pamflet: Boekhistorische, iconografische, literaire en politieke aspecten van pamfletten 1600-1900 (Hilversum: Verloren, 2006).

$\mathrm{Ku}$, Agnes S., 'Revisiting the Notion of "Public" in Habermas's Theory-Toward a Theory of Politics of Public Credibility', Sociological Theory, 18 (2000), pp. 216-40.

Kuyk, J. van, Oude politieke spotprenten (Den Haag: Nijhoff, 1940).

Lacey, Andrew, The Cult of Charles the Martyr (Woodbridge: The Boydell Press, 2003).

Lacey, Antonia, 'Gendered Language and the Mystic Voice: Reading from Luce Irigaray to Catherine of Siena', Juliette Dor, Lesley Johnson and Jocelyn WoganBrowne (eds), New Trends in Feminine Spirituality: The Holy Women of Liège and Their Impact (Turnhout: Brepols, 1999) (Medieval Women: Texts and Contexts, 2), pp. 329-40. 
Lachmann, Fritz Richard, Die 'Studentes' des Christophorus Stymmelius und ihre Bühne (Leipzig: [s.n.], 1926) (Doctoral thesis Leipzig).

Lambert, S., 'Richard Montagu: Arminianism and Censorship', Past \& Present, 124 (1989), pp. 36-68.

Lazarsfeld, Paul, 'Public Opinion in the Classical Tradition', idem, Qualitative Analysis: Historical and Critical Essays (Boston: Allyn and Bacon, 1972).

Leeman, Anton D., and Antoine C. Braet, Klassieke retorica: Haar inhoud, functie en betekenis (Groningen: Wolters Noordhoff and Forsten, 1987).

Lenart, Silvo, Shaping Political Attitudes: The Impact of Interpersonal Communication and Mass Media (Thousand Oaks: Sage Publications, 1994).

Levy, F.J., 'Staging the News', Arthur F. Marotti and Michael D. Bristol (eds), Print, Manuscript \& Performance: The Changing Relations of the Media in Early Modern England (Columbus: Ohio State University Press, 2000), pp. 252-78.

Lie, Orlanda, 'Middelnederlandse literatuur vanuit genderperspectief', Tijdschrift voor Nederlandse Taal- en Letterkunde, 117 (2001), pp. 246-67. (http://www.dbnl.nl/ tekst/lie_002midd01_01/. (23 May 2007).

Lindberg, Carter H., Reformation Theologians: An Introduction to Theology in the Early Modern Period (Oxford: Blackwell, 2002) (The Great Theologians).

- The European Reformations (Oxford: Blackwell, 1996).

Lindenberger, Hebert, Historical Drama: The Relation of Literature and Reality (Chicago etc.: University of Chicago Press, 1975).

Lippmann, Walter, Public Opinion (New York: MacMillan, 1922).

Loftis, John C., Renaissance Drama in England and Spain: Topical Allusion and History Plays (Princeton, N.J.: Princeton University Press, 1987).

Love, Harold, Scribal Publication in Seventeenth-Century England (Oxford: Clarendon Press, 1993).

Luther, Martin, D. Martin Luthers Werke: Kritische Gesamtausgabe, 72 vols (Weimar: Böhlau, 1883-2007).

Lyna, F., 'Een teruggevonden handschrift (Brussel, Hs. II 270)', Tijdschrift voor Nederlandse Taal- en Letterkunde, 43 (1924), pp. 289-323.

Macardle, Peter G., The Allegory of Acolastus: Biblical Allegoresis and its Literary Reflex in Gnapheus's 'Acolastus' (1529), (Durham: Centre for Medieval and Renaissance Studies, Durham University, 2007).

Maczkiewitz, Dirk, Der niederländische Aufstand gegen Spanien (1568-1609): Eine kommunikationswissenschaftlichen Analyse (Münster, New York, Munich, and Berlin: Waxmann, 2005).

Madan, Francis F.A., A New Bibliography of the Eikon Basilike of King Charles the First (London: Quarith, 1950) (Publications of the Oxford Bibliographical Society, N.S., 3).

—_, 'A Revised Bibliography of Salmasius's Defensio Regia and Milton's Pro Populo Anglicano Defensio', The Library, 5th series, 9 (1954), pp. 112-20.

Maguire, Nancy K., Regicide and Restoration: English Tragicomedy, 1660-1671 (Cambridge: Cambridge University Press, 1992).

Mah, Harold, 'Phantasies of the Public Sphere: Rethinking the Habermas of Historians', New Work on the Old Regime and the French Revolution (Special Issue of The Journal of Modern History), 72 (2000), 1, pp. 153-82.

Maissen, Thomas, Von der Legende zum Modell: Das Interesse an Frankreichs Vergangenheit während der italienischen Renaissance (Basel and Frankfurt am Main: Helbing und Lichtenhahn, 1994) (Basler Beiträge zur Geschichtswissenschaft, 166).

Mareel, Samuel, Voor vorst en stad: De literaire productie bij stedelijke feesten ter ere van het huis Habsburg-Bourgondie in Vlaanderen en Brabant (1432-1561) (Amsterdam: Amsterdam University Press, 2010) (Doctoral thesis Ghent, 2007).

Mariken van Nieumeghen \& Elckerlijc, transl. by Willem Wilmink, ed. by Bart A.M. Ramakers (Amsterdam: Prometheus/Bert Bakker, 1998) (Nederlandse klassieken, 13). 
Marnef, Guido, Antwerpen in de tijd van de Reformatie: Ondergronds protestantisme in een handelsmetropool, 1550-1577 (Antwerp and Amsterdam: Meulenhoff, 1996) (Doctoral thesis Leuven, 1991).

Marotti, A.F., Manuscript, Print and the English Renaissance Lyric (Ithaca and London: Cornell University Press, 1995).

Marotti, A.F., and Michael D. Bristol (eds), Print, Manuscript \& Performance: The Changing Relations of the Media in Early Modern England (Columbus: Ohio State University Press, 2000).

McCullough, Peter E., 'Making Dead Man Speak: Laudianism, Print, and the Works of Lancelot Andrewes, 1626-1642', The Historical Journal, 41 (1998), pp. 401-24.

McElligott, Jason, and David L. Smith (eds), Royalists and Royalism during the English Civil War (Cambridge: Cambridge University Press, 2007).

McRee, Benjamin R., and Trisha K. Dent, 'Working Women in the Medieval City', Linda E. Mitchell (ed.), Women in Medieval Western European Culture (New York and London: Garland, 1999), pp. 241-56.

Mead, Margaret, 'Public Opinion Mechanisms Among Primitive Peoples', Katz et al., Public Opinion and Propaganda, pp. 87-94.

Meijer Drees, Marijke, 'Pamfletten: een inleiding', De Kruif, Meijer Drees, and Salman (eds), Het lange leven van het pamflet, pp. 9-28.

Melles, Johannes, Joachim Oudaan, heraut der verdraagzaamheid (Utrecht: Kemink en zoon, 1958).

Mennecke-Haustein, Ute, Conversio ad ecclesiam: Der Weg des Friedrich Staphylus zurück zur vortridentinischen katholischen Kirche (Gütersloh: Gütersloher Verlagshaus, 2003) (Quelle und Forschungen zur Reformationsgeschichte, 74).

Meter, J.H., De literaire theorieën van Daniël Heinsius: Een studie over de klassieke en humanistische bronnen van De tragoediae constitutione en andere tractaten (Apeldoorn: Administratief Centrum 1975) (Doctoral thesis Utrecht).

Meteren, Emanuel van, Historie der Neder-landscher ende haerder Na-buren Oorlogen ende geschiedenissen (The Hague: s.n., 1614).

Meulen, Jacob ter, and Diermanse, Pieter J.J., Bibliographie des écrits imprimés de Hugo Grotius (Den Haag: Nijhoff, 1950).

Meyer, Lodewijk, Verloofde Koninksbruidt, ed. by J.L.P Blommendaal a.o. (Utrecht: Instituut De Vooys, 1978) (Ruygh-bewerp, 7).

Miller, Lesley Ellis, 'Dress to Impress: Prince Charles Plays Madrid, March-September 1623', Samson, The Spanish Match, pp. 27-49.

Moser, Nelleke, 'Maria verklaard: Everaart als exegeet in Maria ghecompareirt byde claerheyt (1511)', Hans van Dijk and Bart A.M. Ramakers (eds), Spel en spektakel: Middeleeuws toneel in de Lage Landen (Amsterdam: Prometheus, 2001) (Nederlandse literatuur en cultuur in de Middeleeuwen, 23), pp. 246-62.

_- De strijd voor rhetorica: Poëtica en positie van rederijkers in Vlaanderen, Brabant, Zeeland en Holland tussen 1450 en 1620 (Amsterdam: Amsterdam University Press, 2001) (Doctoral thesis Amsterdam).

Muller, Frederik, De Nederlandsche geschiedenis in platen: Beredeneerde beschrijving van Nederlandse historieplaten, zinneprenten en historische kaarten, 4 vols (Amsterdam: Muller, 1863-1882).

Muller, Jacob W., and Lodewijk Scharpé, Spelen van Cornelis Everaert (Leiden: Brill, 1920).

Murdoch, Steve, 'The Search for Northern Allies: Stuart and Cromwellian Propagandists and Protagonists in Scandinavia, 1649-1660', Bertrand Taithe and Tim Thornton (eds), Propaganda: Political Rhetoric and Identity 1300-2000 (Stroud: Sutton, 1999) (Themes in History), pp. 79-96.

N.N., Chronycke van Antwerpen sedert het jaer 1500 tot 1575, gevolgd van: Eene beschryving van de historie en het Landt van Brabant, sedert het jaer 51 vóór J.-C., tot 
1565 na J.-C., volgens een onuitgegeven handschrift van de 16e eeuw met Facsimile van het HS (Antwerp: Drukkery van J.P. Van Dieren en Cie. op de Meir, 1843).

Neidhardt, Friedhelm, 'Öffentlichkeit, öffentliche Meinung, soziale Bewegungen', idem (ed.), Öffentlichkeit, öffentliche Meinung, soziale Bewegungen: Sonderheft Kölner Zeitschrift für Soziologie und Sozialpsychologie, 34 (1994), pp. 7-41.

Nellen, Henk, Hugo de Groot: Een leven in strijd om de vrede 1583-1645 (Amsterdam: Balans, 2007).

Nelson, Richard Alan, A Chronology and Glossary of Propaganda in the United States (Westport, C.T.: Greenwood, 1996).

Neurdenberg, Elisabeth (ed.), Van Nyeuvont, Loosheit ende Practike: Hoe sij Vrou Lortse verheffen (Utrecht: A. Oosthoek, 1910).

Nierop, Henk van, "“And Ye Shall Hear of Wars and Rumours of Wars": Rumour and the Revolt in the Netherlands', Pollmann and Spicer, Public Opinion and Changing Identities in the Early Modern Netherlands, pp. 69-86.

— - 'Popular Participation in Politics in the Dutch Republic', Peter Blickle (ed.), Resistance, Representation, and Community (Oxford: Clarendon Press, 1998), pp. 272-90.

Noak, Bettina, Politische Auffassungen im niederländischen Drama des 17. Jahrhunderts (Münster: Waxmann, 2002) (Doctoral thesis Berlin).

Noelle-Neumann, Elisabeth, 'Public Opinion and Rationality', Glasser and Salmon, Public Opinion and the Communication of Consent, pp. 33-54.

—, Die Schweigespirale: Öffentliche Meinung, unsere soziale Haut (Munich: Riper [Piper], 1980). (published in English as The Spiral of Silence: Public Opinion, our Social Skin (Chicago, etc.: University of Chicago Press, 1984).

_-, Öffentlichte Meinung: Die Entdeckung der Schweigespirale (Frankfurt am Main and Berlin: Ullstein, 1996).

O'Callaghan, Michelle, The English Wits: Literature and Sociability in Early Modern England (Cambridge: Cambridge University Press, 2007).

Oey-de Vita, Elise, and Marja S. Geesink, Academie en Schouwburg: Amsterdams toneelrepertoire 1617-1665 (Amsterdam: Huis aan de drie Grachten, 1983).

Oosterhout, Moniek van, Hugo Grotius' Occasional Poetry (1609-1645) (Nijmegen: s.n., 2009) (Doctoral thesis Nijmegen).

Oosterman, Johan B., 'Jenneken Verelst en Anna Bijns: Nieuws over handschrift Leiden, UB, BPL 1289 en zijn inhoud', Spiegel der Letteren, 42 (2000), pp. 49-57.

- - and Bart Ramakers, Kamers, kunst en competitie: Teksten en documenten uit de rederijkerstijd (Amsterdam: Athenaeum-Polak \& Van Gennep, 2001) (Griffioen).

Otto, Beatrice K., Fools are everywhere: The Court Jester around the World (Chicago etc.: University of Chicago Press, 2001) (Doctoral thesis, 1996).

Oudaan, Joachim, Haagsche Broeder-Moord of Dolle Blydschap, intr. and ann. by staff members and students at the Department of Dutch Studies in Utrecht (Utrecht: Instituut de Vooys, 1982) (Ruygh-bewerp, 12).

Page, Benjamin I. and Robert Y. Shapiro, The Rational Public: Fifty Years of Trends in Americans' Policy Preferences (Chicago: University of Chicago Press, 1992).

Papeus, Petrus, Samarites Comoedia de Samaritano Euangelico (Antwerp: Montanus, 1539).

Parente, Jr., James A., Religious Drama and the Humanist Tradition: Christian Theater in Germany and in the Netherlands 1500-1680 (Leiden, etc.: Brill, 1987) (Studies in the History of Christian Thought, 39).

Pers, Dirck Pietersz., Cesare Ripa's Iconologia of Uytbeeldinghen des Verstants (Amsterdam: Dirck Pietersz. Pers, 1644).

Peters, J. Durham, 'Historical Tensions in the Concept of Public Opinion', Glasser and Salmon, Public Opinion and the Communication of Consent, pp. 3-32.

Pettegree, Andrew, Reformation and the Culture of Persuasion (Cambridge: Cambridge University Press, 2005). 
Pikhaus, Patricia, Het tafelspel bij de rederijkers (Ghent: Koninklijke Academie voor Nederlandse Taal- en Letterkunde, 1988).

Pincus, Steven, Protestantism and Patriotism: Ideologies and the Making of English Foreign Policy, 1650-1668 (Cambridge: Cambridge University Press, 1996).

Pleij, Herman, '1512: Antwerpse maagd wint aanmoedigingsprijs op Brussels rederijkersfeest: De grootste rederijker is een vrouw: Anna Bijns', M.A. Schenkeveldvan der Dussen (ed.), Nederlandse literatuur, een geschiedenis (Groningen: Nijhoff, 1993), pp. 126-30.

_ - 'Anna Bijns als pamflettiste? Het refrein over de beide Maartens', Spiegel der Letteren, 42 (2000), pp. 187-225.

_ _ ' 'Komt een vrouwtje bij de drukker... Over nadere verstandhoudingen met Anna Bijns', idem, Komt een vrouwtje bij de drukker: Over gezichtsveranderingen van de literatuur uit de late Middeleeuwen (Amsterdam: Bert Bakker, 2008).

- Het gevleugelde woord: Geschiedenis van de Nederlandse literatuur 1400-1560 (Amsterdam: Bert Bakker, 2007) (Geschiedenis van de Nederlandse literatuur, 2).

Plemper, Pieter, Beschryving van de heerlykheid en het dorp Alphen aan den Ryn: D'aaloude herkomst... en zyne huidendaagze geleegenheid: Doorwrocht met een voegzaame schets van het Heemraadschap van Rynland (Leiden: Hendrik van Damme, 1714).

Poll, Klaas, Over de tooneelspelen van den Leidschen rederijker Jacob Duym (Groningen, J.B. Huber, 1898).

Pollmann, Judith S., 'Countering the Reformation in France and the Netherlands: Clerical Leadership and Catholic Violence 1560-1585', Past \& Present, 190 (2006), pp. 83-120.

-, "Each Should Tend his Own Garden": Anna Bijns and the Catholic Polemic against the Reformation', Church History and Religious Culture, 87 (2007), $29-45$.

Pollmann, Judith S., and Spicer, Andrew (eds), Public Opinion and Changing Identities in the Early Modern Netherlands (Leiden and Boston: Brill, 2007).

Porteman, Karel, and Smits-Veldt, Mieke B., Een nieuw vaderland voor de muzen: Geschiedenis van de Nederlandse literatuur 1560-1700 (Amsterdam: Bert Bakker, 2008) (Geschiedenis van de Nederlandse literatuur, 4).

Potter, Lois, Secret Rites and Secret Writing: Royalist Literature, 1641-1660 (Cambridge: Cambridge University Press, 1989).

Price, Vincent, Public Opinion (Newbury Park: Sage Publications, 1992).

Priebsch, Robert, 'German Pamphlets in Prose and Verse on the Trial and Death of Charles I', Oliver Elton (ed.) A miscellany presented to John Macdonald Mackay (Liverpool: University Press, 1914), pp. 181-98.

Pursell, Brennan C., 'The End of the Spanish Match', The Historical Journal, 45 (2002), pp. 699-726.

- The Winter King: Frederick $V$ of the Palatinate and the Coming of the Thirty Years' War (Aldershot, Burlington: Ashgate, 2003).

Rädle, Fidel, 'Theatralische Formen der Wertekontrastierung im Lateinischen Drama der frühen Neuzeit', Christel Meier, Heinz Meyer, and Claudia Spanily (eds), Das Theater des Mittelalters und der frühen Neuzeit als Ort und Medium sozialer und symbolischer Kommunikation (Münster: Rhema, 2004), pp. 265-88.

_- 'Zum dramatischen Schaffen des Gulielmus Gnapheus im preussischen Exil', T. Haye (ed.), Humanismus im Norden: Frühneuzeitliche Rezeption antiker Kultur und Literatur an Nord- und Ostsee (Amsterdam: Rodopi, 2000) (= Chloe: Beihefte zum Daphnis, 32), pp. 221-49.

Ramakers, Bart (ed.), Op de Hollandse Parnas: De Vlaardingse rederijkerswedstrijd van 1616 (Zwolle: Waanders, 2006).

Ramakers, Bart A.M., 'Dutch Allegorical Theatre: Tradition and Conceptual Approach', Strietman and Happé, Urban Theatre in the Low Countries, pp. 127-44. 
- 'Horen en zien, lezen en beleven: Over toogspelen in opvoering en druk', Bart A.M. Ramakers (ed.), Spel in de verte: Tekst, structuur en opvoeringspraktijk van het rederijkerstoneel (= Jaarboek 'De Fonteine', 41-42 (N.R., 33-34) (1994)), pp. 129-65.

-, 'In utramque partem vel in plures: Werte- und Deutungsdivergenzen im Genter Bühnenwettkampf von 1539', Barbara Stollberg-Rillinger and Thomas Weller (eds), Wertekonflikte-Deutungskonflikte: Internationales Kolloquium des Sonderforschungsbereichs 496 an der Westfälischen Wilhelms-Universität Münster, 19.-20. Mai 2005 (Münster: Rhema, 2007) (Symbolische Kommunikation und Gesellschaftliche Wertesysteme: Schriftenreihe des Sonderforschungsbereichs 496, 16), pp. 197-226.

Randall, Dalle B.J., Winter Fruit: English Drama, 1642-1660 (Lexington: University Press of Kentucky, 1995).

Raupp, Juliana, 'Zwischen Akteur und System: Akteure, Rollen und Strukturen von Öffentlichkeit', Szyska, Diskurs zu einem Schlüsselbegriff der Organisationskommunikation, pp. 113-30.

Ravisius, Johannes, De memorabilibus et claris mulieribus: aliquot diversorum scriptorum opera (Paris: Simon de Colines, 1521). http://www.uni-mannheim.de/mateo/ camenaref/muliers.html (accessed 27 december 2009).

Redworth, Glyn, 'Of Pimps and Princes: Three Unpublished Letters from James I and the Prince of Wales Relating to the Spanish Match', The Historical Journal, 37 (1994), pp. 401-09. http://www.jstor.org/stable/2640209.

- The Prince and the Infanta: The Cultural Politics of the Spanish Match (New Haven and London: Yale University Press, 2003).

Regt, W.M.C., Gedenkboek ter gelegenheid van het 350-jarig bestaan der Nederlands Hervormde gemeente te Alphen aan den Rijn (s.l.: s.n., 1932).

Reigersberch, Maria van, Brieven van en aan Maria van Reigersberch, ed. by H.C. Rogge (Leiden: Brill, 1902).

Ripa, Cesare, Iconologia of Uytbeeldinghen des Verstants, transl. by Dirck Pietersz. Pers (Amsterdam: Dirck Pietersz. Pers, 1644), also www.dbnl.nl (accessed 3 June 2009).

Robbins, Jeremy, 'The Spanish Literary Response to the Visit of Charles, Prince of Wales', Samson, The Spanish Match, pp. 107-21.

Rodríguez Pérez, Yolanda, The Dutch Revolt through Spanish Eyes: Self and Other in Historical and Literary Texts of Golden Age Spain (ca. 1548-1673) (Oxford, etc.: Peter Lang, 2008). (Hispanic Studies: Culture and Ideas, 16) [transl. of De Tachtigjarige oorlog in Spaanse ogen: De Nederlanden in Spaanse historische en literaire teksten (circa 1548-1673) (Nijmegen: Van Tilt, 2005) (Doctoral thesis Utrecht)].

Rooden, Peter van, 'De communicatieve ruimtes van de Nijkerkse beroerten', Joke Spaans (ed.), Een golf van beroering: De omstreden religieuze opwekking in Nederland in het midden van de achttiende eeuw (Hilversum: Verloren, 2001), pp. 125-51.

_- 'Van geestelijke stand naar beroepsgroep: De professionalisering van de Nederlandse predikant', Peter van Rooden, Religieuze Regimes: Over godsdienst en maatschappij in Nederland 1570-1990 (Amsterdam: Bert Bakker, 1996), pp. 46-77.

Roodhuyzen, Jr., Hendrik, Het leven van Guilhelmus Gnapheus, een' der eerste hervormers in Nederland (Amsterdam: Loman, 1858) (Doctoral thesis Leiden).

Roose, Lode, Anna Bijns: Een rederijkster uit de hervormingstijd (Gent: Secretariaat van de Koninklijke Vlaamse Academie voor Taal- en Letterkunde, 1963) (Verhandelingen van de Koninklijke Vlaamse Academie voor Taal- en Letterkunde, 6e reeks: bekroonde werken, 93; Reeks VI: Bekroonde werken, 93).

Rowen, Herbert H. John de Witt, Grand Pensionary of Holland, 1625-1672 (Princeton: Princeton University Press, 1978).

Sabbe, Maurits, Brabant in 't verweer: Bijdrage tot de studie der Zuid-Nederlandsche strijdliteratuur in de eerste helft der 17e eeuw (Antwerpen and Den Haag: Martinus Nijhoff, 1933). http://www.dbnl.org/tekst/sabb002brab01_01/colofon.htm. 
Samson, Alexander (ed.), The Spanish Match: Prince Charles's Journey to Madrid, 1623 (Aldershot and Burlington: Ashgate, 2006).

_-, '1623 and the Politics of Translation', Samson, The Spanish Match, pp. 91-106.

Sánchez Cano, David, 'Entertainments in Madrid for the Prince of Wales: Political Functions of Festivals', Samson, The Spanish Match, pp. 51-73.

Scaliger, Julius Caesar, Poetices libri septem / Sieben Bücher über die Dichtkunst, ed. by Manfred Fuhrmann, Gregor Vogt-Spira and Luc Deitz, 7 vols (Stuttgart-Bad Cannstatt: Frommann Holzboog, 1994-2010).

Schenk, M. and P. Rössler, 'Das unterschätzte Publikum: Wie Themenbewußtsein und politische Meinungsbildung im Alltag von Massenmedien und interpersonaler Kommunikation beeinflußt werden', Neidhardt, Öffentlichkeit, öffentliche Meinung, soziale Bewegungen, pp. 261-95.

Schepper, Hugo De, Peter Ernst, graaf van Mansfeld. http://dutchrevolt.leidenuniv.nl/ nederlands/personen/m/Mansfeld_Peter_Ernst.htm (accessed 17 februari 2009).

Scherpbier, Herman, Milton in Holland: A Study in the Literary Relations of England and Holland Before 1730 (Amsterdam: H.J. Paris, 1933).

Scheurleer, D.F. (ed.), Een devoot ende profitelyck boecxken, inhoudende veel ghestelijcke liedekens ende leysenen, diemen tot deser tijt toe heeft connen ghevinden in prente oft in gescrifte: Geestelijk liedboek met melodieën van 1539 ('s-Gravenhage: Nijhoff, 1889).

Schlögl, Rudolf, 'Politik Beobachten: Öffentlichkeit und Medien in der Frühen Neuzeit', Zeitschrift für Historische Forschung, 35 (2008) 4, pp. 581-616.

Schulte-Sasse, Jochem, 'Einleitung: Kritisch-rationale und literarische Öffentlichkeit', Christa Bürger, Peter Bürger, and Jochem Schulte-Sasse (eds), Aufklärung und literarische Öffentlichkeit (Frankfurt am Main: Suhrkamp, 1980), pp. 12-38.

Scribner, Robert W., 'Oral Culture and the Diffusion of Reformation Ideas', History of European Ideas, 5 (1984), pp. 237-56.

_- For the Sake of Simple Folk: Popular Propaganda for the German Reformation (Cambridge: Cambridge University Press, 1981) (Cambridge Studies in Oral and Literate Culture, 2).

_, Popular Culture and Popular Movements in Reformation Germany (London: Hambledon, 1987).

Selle, Götz von, Geschichte der Albertus-Universität zu Königsberg in Preussen (Königsberg: Kanter Verlag, 1944).

Sellin, Paul R., 'Royalist Propaganda and the Dutch Poets on the Execution of Charles I: Notes towards an Investigation', Dutch Crossing, 24 (2000), pp. 241-64.

Shagan, Ethan H., 'Rumours and Popular Politics in the Reign of Henry VIII', Tim Harris (ed.), The Politics of the Excluded, c. 1500-1850 (Basingstoke etc.: Palgrave, 2001) (Themes in Focus), pp. 30-66.

Sharpe, Kevin M., 'An Image Doting Rabble: The Failure of Republican Culture in Seventeenth-Century England', Kevin M. Sharpe and Steven N. Zwicker (eds), Refiguring Revolutions: Aesthetics and Politics from the English Revolution to the Romantic Revolution (Berkely: University of California Press, 1998), pp. 25-56.

— The Personal Rule of Charles I (New Haven and London: Yale University Press, 1992).

Sharpe, Kevin M., and Steven N. Zwicker (eds), Politics of Discourse: The Literature and History of Seventeenth-Century England (Berkeley, etc.: University of California Press, 1987).

Sharpe, Kevin M., and Steven N. Zwicker (eds), Reading, Society, and Politics in Early Modern England (Cambridge, etc.: Cambridge University Press, 2003).

Shergold, N.D., A History of the Spanish Stage from Medieval Times until the End of the Seventeenth Century (Oxford: Clarendon Press, 1967).

Shergold, N.D., and J.E. Varey, 'Some Palace Performances of Seventeenth-Century Plays', Bulletin of Hispanic Studies, 40 (1963), pp. 212-44. 
Simoni, Anna E.C., 'Poems, Pictures and the Press: Observations on some Abraham Verhoeven Newsletters (1620-1621)', Francine De Nave (ed.), Liber Amicorum Leon Voet (Antwerp: Nederlandsche boekhandel, 1985 (special issue of De Gulden Passer), pp. 353-73.

Smith, Nigel, Literature and Revolution in England, 1640-1660 (New Haven and London: Yale University Press, 1994).

Spaans, Joke, 'De pen als wapen? In handschrift circulerend satirisch rijmwerk over kerkelijke conflicten in de late zeventiende eeuw', De Zeventiende Eeuw, 25 (2009), pp. 90-111.

-, 'Public Opinion or Ritual Celebration of Concord? Politics, Religion and Society in the Competition between the Chambers of Rhetoric at Vlaardingen, 1616', Pollmann and Spicer, Public Opinion and Changing Identities in the Early Modern Netherlands, pp. 189-209.

_- 'The Alphen Pig War', Willem van Asselt a.o. (eds), Iconoclasm and Iconoclash: Struggle for religious identity (Leiden and Boston: Brill, 2007), pp. 331-52.

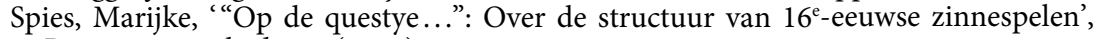
De nieuwe taalgids, 83 (1990), pp. 139-50.

Splichal, Slavko, 'Defining Public Opinion in History', Hanno Hardt and Slavko Splichal (eds), Ferdinand Tönnies on Public Opinion: Selections and analyses (Lanham: Rowman \& Littlefield, 2000), pp. 11-48.

Spruyt, Bart Jan, Cornelius Henrici Hoen (Honius) and his Epistle on the Eucharist (1525): Medieval Heresy, Erasmian Humanism, and Reform in the Early SixteenthCentury Low Countries (Leiden: Brill, 2006).

Staphylus, Fredericus, Confrontation of Articuli Veri with Articuli falsi Gnaphei (1547) (Berlin, Geheimes Staatsarchiv Preussischer Kulturbesitz (GStA PK), Herzogliches Briefarchiv (HBA), J2, K.956, 3, 41, 68).

- Scriptum contra Apologiam Gnaphei (1547) (Berlin, Geheimes Staatsarchiv Preussischer Kulturbesitz (GStA PK), Herzogliches Briefarchiv (HBA), J2, K.971, $3,41,65)$.

Stappers, J.G., A.D. Reijnders, and W.A.J. Möller, De werking van massamedia (Amsterdam: De Arbeiderspers, 19973).

Stegeman, Saskia, Patronage and Services in the Republic of Letters: The Network of Theodorus Janssonius ab Amsteloveen (1657-1712) (Amsterdam: APA-Holland Universiteits Pers, 2005). (in Dutch: Doctoral thesis, Nijmegen, 1997).

Stipriaan René van, Het volle leven: Nederlandse literatuur en cultuur ten tijde van de Republiek (circa 1550-1800) (Amsterdam: Prometheus, 2002).

Strietman, Elsa, 'The Drama of the Rhetoricians in the Low Countries', Dutch Crossing, 22, 1998, pp. 85-100.

Strietman, Elsa, and Peter Happé (eds), Urban Theatre in the Low Countries, 1400-1625, (Turnhout: Brepols, 2006) (Medieval Texts and Cultures of Northern Europe, 12).

Stummelius, Christophorus, Studentes: Comoedia de vita studiosorum (Frankfurt/ Oder: Eichorn, 1550), also CAMENA http://www.uni-mannheim.de/mateo/camena (accessed 5 October 2009).

Szyska, Peter (ed.), Diskurs zu einem Schlüsselbegriff der Organisationskommunikation (Opladen and Wiesbaden: Westdeutscher Verlag, 1999), pp. 113-30.

Tex, Jan den, Oldenbarnevelt, 5 vols (Haarlem: Tjeenk Willink, 1960-1972).

Tilly, Charles, Contention and Democracy in Europe, 1650-2000 (Cambridge and New York: Cambridge University Press, 2004).

Trevor Roper, Hugh, 'Hugo Grotius and England', idem, From Counter-Reformation to Glorious Revolution (London: Secker and Warburg, 1992), pp. 47-82.

Tschackert, Paul, Urkundenbuch zur Reformationsgeschichte des Herzogthums Preussen, 3 vols (Leipzig: Hirzel, 1890).

Tyacke, Nicholas, Anti-Calvinists: The rise of English Arminianism, c. 1590-1640 (Oxford: Clarendon Press, 1987) (Oxford Historical Monographs). 
Aspects of English Protestantism c. 1530-1700 (Manchester: Manchester University Press, 2001) (Politics, Culture and Society in Early Modern Britain).

Vaernewijck, Marcus van, Van die beroerlicke tijden in die Nederlanden en voornamelijk in Ghendt, 1566-1568, 5 vols, ed. by Ferdinand Vander Haeghen (Ghent: C. Annot-Braeckman, 1872-1881).

Valentin, Jean-Marie, 'Aux origines du théatre Néo-latin de la réforme catholique: L'Euripus (1549) de Livinus Brechtus', Humanistica Lovaniensia, 21 (1972), pp. 81-188.

Valentin, Jean-Marie, Les jésuites et le théâtre (1554-1680): Contribution à l'histoire culturelle du monde catholique dans le Saint-Empire romain germanique (Paris: Desjonquères, 2001).

Vandewalle, André, and Ludo Vandamme, 'Het Spaanse Brugge, 1490-1600', Marc Ryckaert a.o., (eds), Brugge: De geschiedenis van een Europese stad (Tielt: Lannoo, 1999), pp. 113-39.

Verkruijsse, Piet J., '“Gedruckt in seghwaer, op de pars der lijdtsaemheyt”: Boekwetenschap en pamfletliteratuur', De Kruif, Meijer Drees, and Salman, Het lange leven van het pamflet, pp. 31-43.

Visser, Casper C.G., Luther's geschriften in de Nederlanden tot 1546 (Assen: Van Gorcum, 1969).

Vocht, Henri De, John Dantiscus and his Netherlandish friends, as revealed by their correspondence, 1522-1546 (Louvain: Librairie Universitaire, 1961).

Vondel, Joost van den, Twee zeevaartgedichten, ed. by Marijke Spies (Amsterdam, Oxford and New York: Noord-Hollandsche Uitgeversmaatschappij, 1987).

Vovelle, Michel, 'Culturele tussenpersonen', idem, Mentaliteitsgeschiedenis: Essays over leef-en beeldwereld (Nijmegen: SUN, 1985), pp. 126-41.

Vree, F. van, De politiek van de openbaarheid: Journalistiek en publieke sfeer (Groningen: Historische uitgeverij, 2000).

Vreese, Willem L. de (ed.), 'Een spel van Charon de helsche schippere', Nederlandsche Dicht- en Kunsthalle, 17 (1895), pp. 261-313.

Vrieler, Joost, Het poëtisch accent: Drie literaire genres in zeventiende-eeuwse Nederlandse pamfletten (Hilversum: Verloren, 2007) (Doctoral thesis Utrecht).

Wagenaar, J., Hedendaagsche historie, of tegenwoordige staat van alle volkeren, 39 vols (Amsterdam: Isaac Tirion, 1742-1750).

Waite, Gary K., 'Rhetoricians and Religious Compromise during the Early Reformation, c. 1520-1555', Strietman and Happé, Urban Theatre in the Low Countries, pp. $79-102$.

Waite, Gary K., Reformers on Stage: Popular Drama and Religious Propaganda in the Low Countries of Charles V, 1515-1556 (Toronto: University of Toronto Press, 2000).

Walz, Herbert, Deutsche Literatur der Reformationszeit: Eine Einführung (Darmstadt: Wissenschaftliche Buchgesellschaft, 1988) (Germanistische Einführungen in Gegenstand, Methoden und Ergebnisse der Disziplinen und Teilgebiete).

Waterschoot, Werner, 'De rederijkerskamers en de doorbraak van de reformatie in de Zuidelijke Nederlanden', Jaarboek 'De Fonteine', 45-46 (1995-1996), pp. 141-53.

Weekhout, Ingrid, Boekencensuur in de Noordelijke Nederlanden: Een verkennend onderzoek naar de vrijheid van drukpers gedurende de zeventiende eeuw (The Hague, Sdu, 1998) (Nederlandse cultuur in Europese context, 11).

Westerbarkey, Joachim, 'Öffentlichkeit und Nicht-Öffentlichkeit: Thesen, Paradoxien und Folgerungen', Szyska, Diskurs zu einem Schlüsselbegriff der Organisationskommunikation, pp. 147-55.

Wijngaards, Nicolaas C.H., 'De zgn. Oranjestukken en hun publiek', Handelingen van het tweeëndertigste Nederlands filologencongres, Utrecht 1972 (Amsterdam: Vereniging Het Nederlandsche Philologencongres, 1974), pp. 117-31.

Wilcher, Robert, The Writing of Royalism, 1628-1660 (Cambridge: Cambridge University Press, 2001). 
Willaert, Frank, De poëtica van Hadewijch in de Strofische Gedichten (Utrecht: HES, 1984) (Doctoral thesis Leuven).

_- and Veerle Fraters, Hadewijchs verzameld werk (Groningen: Historische Uitgeverij, 2009).

Williams, George H., The Radical Reformation (Kirksville, Missouri: Sixteenth Century Journal Publishers, 1992³ ; Philadelphia: Westminster, 1962 ${ }^{1}$ ) (Sixteenth Century Essays and Studies, 15).

Wohlfeil, Rainer, 'Reformatorische Öffentlichkeit', Ludger Grenzmann and Karl Stackmann (eds), Literatur und Laienbildung im Spätmittelalter und in der Reformationszeit (Stuttgart: Metzler, 1984), pp. 41-52.

Woltjer, Jan J., Tussen vrijheidsstrijd en burgeroorlog: Over de Nederlandse Opstand 1555-1580 ([Amsterdam]: Balans, 1994).

Worp, J.A. De briefwisseling van Constantijn Huygens (1608-1687), 6 vols (The Hague: Martinus Nijhoff, 1911-1917).

Worp, J.A., Geschiedenis van het drama en van het tooneel in Nederland, 2 vols (Groningen: Wolters, 1903-1907) I (1903), also www.dbnl.nl [accessed 04 June 2009].

Woude, Cornelis van der, Sibrandus Lubbertus: Leven en werken, in het bijzonder naar zijn correpondentie (Kampen: Kok, 1963) (Doctoral thesis Amsterdam).

Woudhuysen, H.R., Sir Philip Sidney and the Circulation of Manuscripts 1558-1640 (Oxford: Clarendon Press, 1996).

Wright, Abraham, Delitiae delitiarum sive epigrammatum ex optimis quibusque hujus et novissimi seculi poetis in amplissima illa bibliotheca Bodleiana... in unam corollam connexa (Oxford: Leonard Lichfield and William Webb, 1637).

Zaller, J.R., The Nature and Origins of Mass Opinion (Cambridge: Cambridge University Press, 1992).

Zwicker, Steven N., Lines of Authority: Politics and English Literary Culture, 16491689 (Ithaka and London: Cornell University Press, 1993). 



\section{ABOUT THE AUTHORS}

Jan Bloemendal (1961) is a Senior Researcher at the Huygens ING (The Hague) of the Royal Netherlands Academy of Arts and Sciences and Professor of Neo-Latin Studies at the University of Amsterdam. jan.bloemendal@huygensinstituut.knaw.nl / j.bloemendal@uva.nl

Verena E.M. Demoed was a PhD student at the Huygens ING (KNAW) in The Hague and the University of Amsterdam. She has finished her doctoral thesis on the Dutch author of Latin plays Guilielmus Gnapheus, at the University of Amsterdam.

verenademoed@gmail.com

Arjan van Dixhoorn (1973) is currently affiliated with the Department of History at Ghent University as a Postdoctoral Research Fellow of the Research Foundation-Flanders (FWO).

arjan.van.dixhoorn@telenet.be

Juliette Groenland (1973) was a Postdoctoral Fellow. She is now a teacher at a secondary school.

j.a.groenland@neo-latin.com

Helmer Helmers (1977) is a lecturer in Dutch literature before 1800 at the University of Groningen. His research focuses on Anglo-dutch interaction in the 16th and 17th centuries. He has recently completed his doctoral thesis, The Royalist Republic, at Leiden University. h.j.helmers@rug.nl

Judith Kessler (1980) is working on her doctoral thesis about Anna Bijns' poems, to be completed in 2011. She is teaching modern German literature and older Dutch literature at Radboud University. j.kessler@let.ru.nl

Samuel Mareel (1974) is a Postdoctoral Research fellow of the Research Foundation-Flanders (FWO) at the department of literature at Ghent University. samuel.mareel@ugent.be 
Nelleke Moser (1970) is an Assistant Professor of early modern Dutch literature at the Faculty of Arts of VU University Amsterdam. Her research focuses on Dutch manuscript culture.

ph.moser@let.vu.nl

Moniek van Oosterhout (1971) obtained her PhD at Radboud University Nijmegen in 2009. She is currently teaching Classics at a secondary school in Nijmegen.

m.voosterhout@canisiuscollege.nl

Jo SpaAns (1956) is a Senior Lecturer in the history of Christianity at Utrecht University and is the supervisor of the NWO-funded project 'Fault line 1700: Early Enlightenment Conversations on Religion and the State'.

j.w.spaans@uu.nl

Elsa Strietman is a Senior Lecturer in the Department of German and Dutch in the Faculty of Modern and Medieval Languages, University of Cambridge, and Fellow, Tutor and Vice President of Murray Edwards College (formerly New Hall), Cambridge.

es10004@cam.ac.uk 


\section{INDEX OF NAMES AND SUBJECTS}

Albert (1490-1568, Duke of Prussia 1525-1568) 94, 95, 97

Anglo-Dutch War, First (1652-1654) 222, 226, 229, 239-47

Anslo, Reyer (Dutch poet, 1626-1669) 223, 225

Kroonrecht door gewelt verkracht 223

Aristotle (Greek philosopher, 384-322 BC) 126, 127, 133, 134, 282

Arminius, Jacobus or Jacobus Hermansz (Leiden professor of theology, ca. 1559-1609) x, 151-79

Arminianism see Religion, Arminianism

Bakker, Jan de (or Johannes Pistorius, 1499-1525) 95, 96, 284

Bara, Jan (Dutch playwright and poet, 1627-c. 1706) 235, 237, 238 Herstelde Vorst (1650) 235, 237, 238, 247

Barlaeus, Caspar (Dutch theologian, poet and historian, 1584-1648) 157

Battle of White Mountain (1620) 183, $184,186,192,194,195,196,198,204$, 205, 206, 208-13

Baudius, Dominicus or Dominique Baude (Dutch Neo-Latin poet, scholar and historian, 1561-1613) 162-67 Epicedium dictum honori Jacobi Arminii (1609) 162-64, 173

Beatrijs of Nazareth (Dutch prioress and author, 1200-1268) 56, 70

Beeldenstorm see Iconoclasm

Beggars see Geuzen

Beguine 56, 57

Bertius, Petrus or Pieter de Bert (Flemish theologian, historian and cartographer, 1565-1629) 157, 160, $163,164,166,167$

Oratio In obitum Iacobi Arminii (1609) 160-62, 165, 173

Bestandstwisten see Truce Conflicts Bible $7,9,65,72,74,77,78,79,155$, $157,160,234$

Biblical 30, 35, 73, 94, 103, 116, 124
Holy Scripture 77, 79

Bijns, Anna (Dutch poetess, 1493-1575) $\mathrm{x}, 55-86,270,271,277-78,279,284$, 286

Bijns, Margriete (sister of Anna Bijns) 58

Bijns, Meerten (brother of Anna Bijns) 58

Blijde Inkomste see Joyous Entry

Bouman, Adriaan (Voetian minister of Alphen 1682) 257-59, 262, 263

Brandt, Geeraerd (Remonstrant poet, 1626-1685) 2, 222, 224, 225, 237

Bray, William (English chaplain and Canterbury canon, d. 1644) 169

Brechtanus, Levinus (Antwerp Franciscan and playwright, 16th c.) $67,74,78,81,85$

Briesmann, Johannes (Lutheran bishop, 1488-1549) 97

Buckingham, Duke of see Villiers, George

Bullinger, Heinrich (Swiss reformer, 1504-1575) 96 Summa Christlicher Religion (1556) 96

Calderón or Pedro Calderón de la Barca (Spanish playwirght, 1600-1681) 184

Amor, honor y poder (1623) 184, 193, 194, 200, 202

Calvin, John (French reformatory theologian, 15090-1564) 61

Capellen, Alexander van der (Dutch nobleman, c. 1594-1659) 242, 243

Cartwright, William (English poet, 1611-1643) 167, 168, 170 Comedies, tragi-comedies, with other poems, (1651) 170

Cary, Lucius (second Viscount of Falkland, d. 1643) 169

Casparius, Casparus or Caspar Ens (German and Dutch teacher and Latin playwright, 1569-after 1642) 8, 125 Auriacus, sive Libertas defensa (1599) 
Castelein, Matthijs de (Flemish rhetorician and chaplain, ca. 1485-1550) 59, 71

Conste van rhetoriken (1555) 71

Catherine of Siena (Roman catholic saint, 1347-1380) 70, 79, 83

Caussin, Nicolas (French Jesuit poet, 1580-1651) 34, 35, 289

Charles I (1600-1649) King of England, Scotland and Ireland (1625-1649) 167, 168, 169, 183-86, 190, 193-194, 196-203, 206, 207, 211, 212, 219, 221, $224,225,226-247,248,249,272,279$, 280, 282, 283

Martyrdom of 225, 226-247 in Eikon Basilike 225, 226, 227

Charles II, King Scotland (1649-1685), King of England and Ireland (1660-1685) x, 219, 220, 221, 224, $225,233,234,235,237,238,239,241$, 243, 244, 246, 248, 249, 283

Charles the Bold (1433-1477, Duke of Burgundy 1467-1477) 46

Charles V (1500-1558, Emperor of the Holy Roman Empire, 1519-1556) 37, 38, 41, 42, 44, 47, 48, 51, 198

Charles, Prince of Wales see Charles I

Civil War 226, 233

In England (1642-1649) 13, 223, 225, 235, 237, 247

In Holland see Truce Conflicts

Coccejus, Johannes (Dutch theologian, 1603-1669) 256

Coccejan 257

Coleridge, Samuel Taylor (English poet and philosopher, 1772-1834) 128

Coloma de Saa, Carlos (Spanish military commander, diplomat and author, 1566-1637) 204

Communication theory $19-23,24,283$, 286

Agenda-setting theory 25-26, 28, 34, $35,278,280,288$

Two-step-flow theory 25, 278

Users-and-gratifications theory 24

Conventus praeparatorius 155

Cooke, John (1608-1660), solicitor general 230

Coster, Samuel (Dutch poet, 1579-1669) 229 Iphigenia (1617) 229

Cromwell, Oliver (1599-1658), general, Lord Protector (1653-1658) 221, 229, 235, 237, 248
Dalen, Johan van (Dutch printer, fl. 1624[?]-1665) 221, 244

Decker, Jeremias de (Dutch poet, 1609-1666) 222

Dene, Eduard de (Bruges rhetorician, ca. 1505-ca. 1578) 270, 275, 276 Testament Rhetoricael (1561) 275

Digby, John (Earl of Bristol, 1580-1653) 200

Donck, Enghelbrecht vander (Dutch compiler of poems) 61

Dousa, Janus or Jan van der Does (Dutch nobleman, classical scholar and Latin poet, 1545-1604) 131

Drama $\mathrm{x}, 6,10,37,38,43,45,46,51,52$, $53,91,92,93,104,182,203,212,271,278$ Autos sacramentales 193

Allegorical 7, 33, 38, 45, 53, 60, 100, 103, 104, 105, 106, 108, 139, 237, 273

Biblical 129, 132, 169

Comedy 9, 93, 103, 138, 190, 199, 212, 216, 217

Farce 1, 9, 190, 192, 208, 216, 217

History 121-150

Jesuit 190, 192, 289

Latin $\mathrm{x}, 34,78,91-119,124-26$, 129-35, 190, 284, 289

Morality play $9,43,91-119$

Rhetoricians see Rhetoricians-Drama

Royalist 226-247, 248

Senecan $121,132,136,141,144$, 225, 226-39, 245, 247-49, 278

Tableau vivant 27, 34, 92, 111, 289

Tragedy $q . v$.

Tragicomedy 9, 115

Drie Santinnen, De 37

Dullaert, Johan (Dutch poet, 1630-after 1681) 224, 226-32, 237, 248

Karel Stuart of Rampzalige Majesteyt 226-32, 247

Dury, John (Scottish Calvinist minister, 1596-1680) 168

Dutch Republic or United Provinces $2,14,124-26,127,128,134,137,138$, $139,140,145,147,151-57,165,168$, $171,183,199,219,220,221,222,226$, $229,231,241,244-45,246,247,248$, 249, 271

Friesland 208, 209

Holland (province) 2, 93, 96, 121, 125 , $139,140,208,209,220,221,222$, $228,231,237,239,241,242,243$, $244,247,251,252,253,258,259$, 271,286 
States of $128,129,131,132,155$, 156, 165, 166, 221, 226, 229, 231, 241, 255, 259, 271

Zeeland (province) 2, 208, 209, 220, 231, 242, 251, 258

Dutch Revolt (1568-1609) 1, 2, 13, 47, $69,121,124,133,136,144,152$

Duym, Jacob (1547-before 1624) x, 29, $30,31,121-23,125,126,146,147$, 148, 149, 273, 278, 279, 286

Een bewys dat beter is eenen goeden crijgh, dan eenen gheveynsden peys (1606) 137, 138, 139

Ghedenck-boeck (1606) 135-41

Moordadich Stuck van Balthasar Geerardts (1608) 29, 121-23, 125, $129,130,131,134,135-45,146$

Spiegelboeck 136

Spieghel der Eerbaerheyt (1595) 136

Den spieghel der Getrouwicheyt (1600)

Den Spieghel deshoogmoets(1600) 136

Spieghel der liefde (1596) 136

Spieghelder rechtvoordering(1592) 136

Den Spieghel der Reynicheyt (1600) 136

Dwerck der Apostelen cap. 3, 4 en 5 (before 1539) 106

Education $\quad 6,24,26,70,78,94,102$, $131,134,141,148,159,171,277$

Jesuit colleges 190

Latin School 6, 92, 93, 94, 95, 102, $125,126,146,165$

University $70,78,92,95,96,97,121$, $126,129,131,133,136,141,145,146$, $152,153,154,155,165,220,270,278$

Edward III (1312-1377, King of England 1327-1377) 200

Edward Hyde, Earl of Clarendon (1609-1634) 241, 243

Eembd, Govert vander (Dutch rhetorician and playwright, d. ca. 1623) 125

Haerlems belegerings treur-blij-eyndespel (1619) 125

Eikon Basilike see Charles I

Elckerlijc 78, 103, 104

Eleanor of Austria (Archduchess of Austria and Infanta of Castile, 1498-1558, Queen consort of Portugal 1518-1521, of France 1530-1547) 39

Elizabeth (1596-1662), Queen of Bohemia (1619-1620) 183, 202
Elizabeth (1533-1603), Queen of England (1588-1603) 209

Enlightenment $12,14,19$

Ens, Caspar see Casparius, Casparus

Episcopius, Simon or Bisschop (Dutch protestant theologian, 1583-1643) 157, 161

Threnus (1609) 161

Erasmus, Desiderius (Dutch theologian and biblical humanist, 1466?-1536)

9, 49, 106, 110, 281

Adagia (1500) 110, 116, 124, 274

Colloquia 9

Institutio principis Christiani (1516) 127

Laus Stultitiae / Praise of Folly

(1511) 49, 106, 281

Eucharius, Eligius or Gillis Houckaert (Ghent priest and Latin playwright, ca. 1488-1544) $65,81,82,85$

Everaert, Cornelis (Dutch rhetorician and playwright, ca. 1480-1556) $\mathrm{x}$, 37-53, 273-74, 281, 286

Ghewillich Labuer ende Volck van Neerrynghe (1526) 38, 39, 41, 44, 47, 51, 52

dOnghelycke Munte (1530) 37, 38, 39, 42, 43, 44, 45, 47, 48, 50, 51, 52

Pays (1538) 38, 39, 41, 42, 44, 47, 48, 49, 50, 52

Van Groot Labuer en Sober Wasdom 281

Everyman 104

Excellente Cronike van Vlaenderen 46

Ferdinand II (1578-1637, Holy Roman Emperor 1619-1637, King of Bohemia 1617-1619, 1620-1637) 183, 184, 190, 192, 217

Francis I (1494-1547, King of France 1515-1547) 38, 41, 47

Franciscans $\mathrm{x}, 55,56,58,61,65-68$, $70,74-80,83,84,85,86,270,277$, 278

Minorites 55, 67, 277, 283

Frederick Henry (1584-1647, Prince of Orange, Stadtholder in the Northern Netherlands, 1625-1647) 137, 145, 146, 209, 210, 220, 243

Frederick V (1596-1632, Elector Palatine 1610-1623, King of Bohemia 1619-1620) 183, 184, 185, 190, 192, $194,210,217$

Frederik Hendrik see Frederick Henry 
Gelderland, Adolf van 38

Gelderland, Arnold van 38

Gerards, Balthasar (murderer of William of Orange, ca. 1557-1584) 29, 121, $130,141,142$

Geuzen 32

Ghelen, Jan van (Antwerp printer, 1577-1598) $65,66,87,88$

Gheenste, Stevijn vanden (Bruges rhetorician, 16th c.) 66

Gnapheus, Guilielmus or Willem de Volder (Dutch rector and Lutheran playwright, 1493-1568) x, 91-119, 279, 284, 286

Acolastus (1529) 93, 96, 103

Foetura (1541) 94

Hypocrisis (1544) x, 81-119, 284

Morosophus (1541) 93, 94, 97, 98, 103, 116

Paraenesis (1539) 94

Tobias ende Lazarus (1557) 93, 95

Triumphus Eloquentiae (1541) 93

Een troost ende spiegel der siecken (1531) 93, 95, 114, 116

Goethe, Johann Wolfgang von (German poet and playwright, 1749-1832) 124

Gomarus, Franciscus (Leiden professor of theology, 1563-1641) 153, 154, 156, 159, 161, 162, 166, 167, 270, 279

Grotius, Hugo or De Groot (Dutch jurist and diplomat, 1583-1645) $\mathrm{x}$, $26,127,128,129,130,131,151-79$, 270, 277, 279, 280, 286

Adamus exul (1601) 129

Christus Patiens (1608) 169

Epicedium (1609) 151-79

Liber de antiquitate reipublicae Bataviae (1610) 127

Ordinum Pietas (1613) 160

Poemata Collecta (1617) 160, 167, 169, 173

Sophompaneas (1635) 169

Guilds 58

St. Ambrosius guild for teachers

Habermas, Jürgen (German social historian) $3,4,11-19,21,28,149$, $181,260,268,286$

Habsburg, house of see Charles V, Eleanor of Austria

Hadewijch (Flemish nunn and poetess, d. 1248) 56,70
Haywood, William (English chaplain, 17th c) 168,169

Heinsius, Daniel (Dutch philologist, poet and playwright, 1580-1655) x, 121-23, $125,126,128,129-35,137,142,143$, 144, 224, 272, 273, 278, 279, 286

Auriacus, sive Libertas saucia

(1602) 8, 121, 122, 123, 125, 128, 129-35, 137, 141-42, 144, 145-49, 272

De tragoediae constitutione (1611) 126, 133

High Council 156

Hildegard of Bingen (German mystic author, 1098-1179) 79

Hoen, Cornelius Henrici (Lawyer of the Court of Holland and Lutheran, d. 1523/1524) 93, 284

Hogendorp, Gijsbrecht van (Amsterdam rhetorician and playwright, 1589-1639) 125, 134, 135

Treur-spel van de moordt (1616) 125

Holland (province) see Dutch Republic

Holles, Sir John (Earle of Clare, c. 1564-1637) 204, 205

Hooft, Pieter Cornelisz. (bailiff, historian and playwright, 1581-1647) 1-3, $9,121,125,127,128,134,135,228$, 281

Baeto (1617) 121, 125, 127, 135

Geeraerdt van Velsen (1613) 121, $125,135,228$

Nederlandsche Historiën (1642-1647) 1

Humanism $\mathrm{x}, 6,16,34,65,67,79,81$, $92,93,102,103,108,121,122,123$, $125,126,127,131,132,133,134,136$, $145,146-47,149,163,267,270,277$, $279,284,288$

Hurtado de Mendoza, Antonio (Spanish poet, 1586-1644) 198

Huydecoper, Johan (Burgomaster of Amsterdam, 1599-1661) 246, 271

Huygens, Constantijn (secretary to the House of Orange and poet, 1596-1687) 224, 241, 243, 245 Hofwyck (1653) 245

Hyde, Edward (1609-1674), advisor of Charles II, 1st Earl of Clarendon (1661) 241, 243, 244

Iconoclasm or Beeldenstorm 32, 192 Inquisition $29,30,143$ 
James I (1566-1625) King of Scots (as James VI, 1567-1625), King of England (1603-1625) 183, 184, 202 Jesuits $34-35,78,105,143,184,190$, 192-93, 194, 203, 204, 205, 211, 212, $217,218,279,289$

John of Austria or Don Juan (1547-1578, Governor General of the Low Countries 1577-1578) 135

Joyous Entry or Blijde Inkomste 34, 289

Junius, Franciscus (Dutch philologist, 1589-1677) 153, 162

Keerberghe, Jan van (Antwerp printer 1586-1624?) $67,77,88$

Laud, William (1573-1645, Archibishop of Canterbury, 1633-1645) 167, 168, $169,170,171,237$

Lerma, Duke of or Francisco Gómez de Sandoval y Rojas (1552/53-1625, prime minister of Spain 1598-1618) 200, 202

Liesvelt, Jacob van (Antwerp printer, ca 1489-1545) 61, 65, 87

Literature ix, 2, 3, 5-11, 12, 17, 33-35, $43,56,60,70,78,91,106,123,126$, $131,133,147-50,183,185,186,211$, 213, 222, 226, 246, 247, 249, 260, 261, $267,278,285,289,291$

Allegory $7,33,35,38,39,43,45,47$, $48,49,52,53,60,100,103-05,106$, $108,115-16,118,139,228,234-35$, 237, 273, 281, 289

Ballad 31, 34, 59

Ballade 9, 138, 289

Bonae litterae 6, 94, 148

Dialogues 9, 33, 35, 50, 114, 195, 289

Didactic poetry $9,18,31,46,52$, 103, 104, 132

Encoding 7, 8, 9, 10, 289

Epic 9

Genre $8-9,33,43,57,59,92,123$, $131,132,148,171,225,226,234$, $247,278,282,285$

Letters $9,31,33,67,68,74,75,81$, $93,97,101,138,153,155,195$

Mimesis 126,148

News-letters $181,182,189,195,196$

Oral ix, 2, 3, 4, 6, 7, 11, 12, 13, 14, $17,25,27,28,33,45,181,252,263$
Pasquil 31, 32, 33, 261

Songs $2,6,9,10,11,15,26,27,31$, $34,35,46-47,59,82,222,251-63$, 270, 282, 289

Lope de Vega or Félix Lope de Vega y Carpio (Spanish playwright, 1562-1635) 124

Louis XI King of France (1423-1483, King of France 1461-1483) 46

Lubbertus, Sibrandus (Dutch reformed theologian, 155-1625) 155

Lucian (ca A.D. 125-after 180) 50 Charon or the Inspectors 50

Luther, Martin or Maarten (German reformer, 1483-1546) 55-59, 61, 64-69, 73-77, 81, 82, 83-86, 92, 94, $108,110,113,117,118,277,284$ Lutheran see Religion, Lutheran

Mander, Karel van (Dutch painter, poet and biographer, 1548-1606) 136

Mansfelt, Peter Ernst of 67

Manuscripts $\mathrm{x}, 10,16,31,32,37$, $46,56,57,59,60,61,63,89,132$, $153,155,170,171,181-218,251$, $251,252,267,271,275,278,280$, 281, 287, 288

Margareth of Parma (1522-1586, Governess of the Low Countries, 1559-1567) 276

María Anna of Austria (Infanta of Spain, 1606-1646) 183, 185, 190, 193, 197, 200, 212, 280

Mariken van Nieumeghen (ca. 1518) 38, 78

Marvell, Andrew (English poet, 1621-1678) 248

Mary of Montmorency 67

Maurice of Nassau (1567-1625, Prince of Orange, Stadtholder) 137, 138

Meer, Jacob van der 256

Meyer, Lodewijk (Dutch poet, 1629-1681) 238-39, 247

Verloofde Koningksbruidt (1668) 238-39

Middleton, Thomas (English playwright and poet, 1580-1627) 203-05, 212 A Game at Chess (1624) 203-05, 212

Milton, John (English secretary and poet, 1608-1674) 220, 221, 222, 224, 234

Defensio pro populo anglicano (1651) 220 
Moulin, Pierre du (French-English Anglican clergyman, 1601-1684) 244, 245

Regii sanguinis clamor ad coelum (1652) 244

Wraak-geschrey van het Koning-lijke bloed (1652) 244, 246, 247

Muller, Jacob Wijbrand 38,51

Naogeorgus, Thomas or Kirchmeir (Protestant cleric and playwright, $\begin{array}{ll}\text { c. } 1508-1563) & 103,117\end{array}$ Pammachius (1538) 117

Nassau, Maurice of see Maurice

Oldenbarnevelt, Johan van (1547-1619, Grand Pensionary of Holland 1586-1619) 30, 137, 138, 139, 147, $151,152,160,162,167,224,228$, 229, 248

Olivares, Count of or Gaspar de Guzmán y Pimentel (1587-1645, Spanish prime minister 1621-1643) 197, 198, 199, 200, 201-04, 284

On a Shew presented before Prince Charles in the Spanish Courte 206

Orange, House of see Maurice, Frederick Henry, William II Orangism 224

Orange, Maurice of see Maurice

Orange, William II of see William II

Oudaen, Joachim (Rotterdam poet, 1628-1692) 8, 222, 223, 224, 226, 271

Haegsche broeder-moord, of dolle blydschap (1673) 8

Palatinate $185,192,203,212$

Pamphlets 1, 7-10, 13, 27, 33, 68, $79,91,92,93,95,97,112,117$, $125,138,151,160-67,181-218$, $219,223,229,230,235,238,239$, $243,245,246,251,252,260,261$, 263, 273, 287

Advertissement [...] aen die goede catholycke borghers van Mechelen 32-33

De Geest van Karolus Stuart 230, 237, 238

De iure belli Belgici adversus Philippum regem Hispaniarum 8 Relaciones 195, 196, 211
Schuitepraatjes 9

Het Toneel der Engelsche Elenden 235

Wonderlijcke Geest des Conincx 230

Panagius Salius (Toussaint du Sel) 125 Nassovius (1589) 125

Parma, Duke of or Alexander Farnese

(1545-1592, Governor of the Spanish

Netherlands 1578-1592) 135

Passional Christi und Antichristi (1521) 112, 117

Pauw, Adriaen (1585-1653, Grand Pensionary of Holland 1631-1636 and 1651-1653) 241

Peace Truce

Cambrai (1529) 37, 38, 44

Madrid (1526) 38, 41, 44, 51

Nice (1538) 38, 41, 42, 44, 47

Pers, Dirck Pietersz. (Dutch printer, poet and prose author, 1581-1659) 106, 274

Cesare Ripa's Iconologia (1644) 106, 274-75

Philip II (1527-1598, King of Spain 1556-1598) 8, 121, 135

Philip III (1578-1621, King of Spain 1598-1621) 8, 201

Philip IV (1605-1665, King of Spain 1621-1665) 183, 196, 201

Pippinck, Hendrick (Flemish priest, provincial head of the Franciscans in the Low Countries and author, 16th c.) $67,68,77,78,79,80,81$, 84,85

Pistorius, Johannes see Bakker, Jan de

Plancius, Petrus (Dutch clergyman, d. 1622) 154,155

Popular Print see Printing press

Praepositus, Jacobus or Probst

(German evangelical theologian, 1486-1562) 58

Prochiaen, Coster en Wever (1538-1540) 113

Printing press $13,14,27,57,164,181$, 185, 260, 261, 287

Pamphlets q.v.

Popular prints 260

Propaganda $53,92,109,116,117,133$, 182, 185, 198, 199, 204, 205, 212, 261, 283, 284

And the stage 149,202

Aimed at international audiences 35 , 197 
Definition 282, 283

For royalist cause 219-49, Public

Audience 10, 20, 21-23, 25, 33, 35, $43,45,49,50,52,53,92,96,102$, $104,105,106,115,122-23,125$, $126-29,131,132,133,134,135$, $137,144,146-50,156,165,170$, $182,183,190,193,194,197,199$, $204,205,210,230,233,237,247$, 249, 260, 270-73, 277, 278, 280, 282, 286, 287, 289, 290, 291

Institutions $11,17,21,22,26,29$, $59,122,125,155,267,268,269$, $270,277,285$

Networks 3, 14, 17, 21, 22, 23, 25, $26,28,34,61,102,136,260,262$, $267,269,270,271,277,283,284$, 286, 288

Readership 20, 92, 102, 114, 291

Public opinion passim

Actor-oriented research 21

Agenda setting 25, 26, 28, 34, 35, $278,280,288$

Authority $12,44,50,51,55,56-57$, $70,71,74,75,77,78,80-81,83$, $84,86,103,127,163,230,233,234$, $259,261,262,276-78,281,283$, 289, 290

Ethic 18, 277

Of the inspired 277

Outsider 277

Representative 277

As a result of self-presentation 35,56

Censorship 2, 55, 65, 166, 169, 203, $220,262,269,279,281-82$

Contemporary notions of 273-76

Debate passim

Phases 24, 28

Definition

Classical elitist 19,20

Democratic 19-20

Postmodern or Dynamic 20, 181, 182, 270, 273, 285

Formation of ix, x, 3-5, 15, 17, 18, 19-20, 23-26, 27, 28, 29-31, 43, 45, $47,48,52,147,149,181,182-183$, $185,213,268-70,274,277,282$, $283,285,287-88,288-91$

Gossip 9, 37, 38, 39-41, 49, 52, 53, 257, 274, 275

Opinionleaders $\quad 25,26,28,276,277,290$
Publics 3, 20, 268, 269-73, 288

Pulpit, see Public opinion, sermon

Representativeness of 16, 34, 269-73, 277, 291

Sermon (as a means to influence-) $15,55,79,114,154,182,254,258$, 260, 261

Songs (as a means to influence-) $2,15,251-266$

Sources for the study of $4-5,22$, 56-57, 147, 181-84, 186, 185, 195, $198,213,269,285-88,290$

System-oriented research 21

Public sphere $3,11-14,18,19-24$, 26-31, 33, 35, 196, 221, 261, 267-69, 289

Bourgeois 11, 13, 14, 16, 17, 19

Networks 3, 14, 17, 21, 22, 23, 25, $26,28,34,61,102,260,267,269$, 270-71, 277, 283, 284, 286, 288

Reformatory or Protestant 13

Representative 12, 13, 268

Quevedo, Francisco de or Francisco Gómez de Quevedo y Santibáñez Villegas (Spanish nobleman, politician and author, 1580-1645) 202

Cómo ha de ser privado (1629) 202

Quintilian (Roman rhetorician, ca. A.D. 30-ca. 100) 78

Religion

Anabaptist 94, 97, 101, 284

Arminianism 151, 160, 162, 166, $167-72,270$

Augustinian 58, 81

Calvinist, Calvinism 10, 32, 67, 68, 95, 96, 129, 153-157, 167, 171, 210, $225,229,239,268,271$

Carmelite friar 190, 192

Counter-Remonstrants 30,152, 154, $157,160,166,167,224,229$

Evangelical 12, 73, 93, 96, 101, 109, $112,118,284$

Lutheran $42,55-56,82,91,95,97$, $98,99,101,102,109,117,118,277$, 284

Pope 55, 106, 112, 113, 116, 117, 202, 206, 207, 210, 211, 212

Reformation 2, 12, 13, 14, 92, 93, $102,103,116,119,152,182,284$

Calvinist 268

Catholic 268

Lutheran 91, 92, 111, 112, 268 
Protestant 12, 13, 91, 268

Radical 268

Reformed Church 2, 97, 257, 271

Remonstrants $30,152,154,157,160$, 166, 167, 224, 229, 230, 248

Roman Catholic 32, 33, 55, 56, 58, $65,67,68,73,78,82,84,91,94$, $95,97,99,100,101,102,105,106$, $107,108,109,110,111,112,114$, $117-19,141,152,160,192,197$, 198, 199, 201, 204, 212, 217, 268, $270,271,279,283,284$

Sacramentarian 94, 284

Zwinglian 96, 284

Respublica literaria 6, 92, 102, 267

Revenge tragedy 219, 225-28, 231-32, 234-35, 238, 247, 249

And civil war 225-26, 235, 237, 247

Rhetoric 7, 18, 19, 35, 162, 224, 229, 248, 267, 289

Of revenge $225,226,231,239,245$, 247, 277

Rhetoricians $\mathrm{x}, 1,2,7,30,34,37,46$, $52,57,59,60,72,143,144,208,209$, $210,267,270,288-89$

And argumentation $60,273,280$

Chambers ix, $1,6,7,28,34,38,57$, $59,126,149,267$

'De Akerenboom' 30

'De Drie Santinnen' 37

'De Heilige Geest' 37

'd'Orainge Lelie' 136, 141

'De Roode Roosen' 30

'De Witte Acoleyen' 136, 141

Contests 38, 59, 60, 138, 267

Culture 267, 278

Drama $108,111,113,122,144,145$, 146, 182, 276

Charon de Helsche Schippere (1551) 50

Morality play $9,43,92,103,104$, 107, 108, 110, 118

Sinnekens $44,48,50,52,108,143,276$

Spel van zinne $43,44,45,46,49$, $51,52,53$

Tafelspel 113

Van Nyeuvont, Loosheit ende

Practike (between 1497 and 1501) 49-50

Rederijkers 59

Refrains $57-61,64,65,66-69,71$, $72,73,74-75,77,78,80-86$
Ripa, Cesare (Italian emblematist, ca. 1560-ca. 1522) 106, 274, 275 Iconologia (1593) 106, 274, 275

Roosenboom, Adriaan (sheriff of Alphen) 256

Roosenboom, Frederick 256

Roosenboom, Huybert 251, 256, 260, 262, 263, 266

Rossum, Maarten van (Guelderian military tactician and field marshal, ca. 1478-1555) 60-61

Royalism 223, 224 In Holland 223-24

Rumour 45, 47, 48, 53, 139, 263, 274, 275 Definition of 48

Sandys, George (English translator, d. 1644) 169

Sappho (Greek poetess, 7th c. BC) 78

Saumaise, Claude de see Salmasius, Claudius

Salmasius, Claudius or Claude Saumaise (Huguenot scholar, 1588-1653) 219, $220,221,222,223,224,225,229,233$, 234

Defensio Regia (1649) 219, 220, 231, 233, 244

Scaliger, Josephus Justus (French philologist and Leiden professor, 1540-1609) 103, 131, 133

Scaliger, Julius Caesar (French humanist and physician, 1484-1558) 133

Schele, Radboud Herman (political theorist, 1622-1662) 224

Schellart 32, 33 Advertissement see Pamphlets, Advertissement

Scriverius, Petrus or Pieter Schrijver (Dutch philologist and poet, 1576-1660) 130, 131

Seneca, Lucius Annaeus (Roman philosopher and playwright, c. 1 B.C.-64) 132

Agamemnon 228, 237, 248

Octavia 132

Thyestes 238

Troades 136, 141, 144, 229

Senecan tragedy $121,132,225,227$, 235, 238, 247, 248, 278

Sermon see Public Opinion, Sermon

Shakespeare, William (playwright, 1564-1616) 124, 228, 238, 248 
Hamlet 228, 237, 238, 248, 249

Titus Andronicus 231

Six van Chandelier, Jan (Dutch poet, 1620-1695) 222, 225

Spanish Match (1623) x, 183-86, 195-203, 206, 211-12, 280, 284, 286, 287

Staphylus, Fridericus or Friedrich Stapellage (German Lutheran theologian, 1512-1564) 91, 96-102, 111,118

States General $\quad 67,152,163,231,241,242$

States of Holland (and West Frisia) 128, $129,131,132,155,156,165,166,220$, 221, 226, 229, 231, 241, 255, 259, 271

Stevijn see also Gheenste, Stevijn vande

Stevin, Simon (Dutch mathematician and inventor, 1548-1620) 256

Stevin, Hendrik 256

Stuart, Charles (1600-1649) see Charles I Stuart, Charles (1630-1685) see Charles II

Supreme Court 156, 251, 258, 259, 260

Topicality, topical poetry 121,122 , $123,124,126-29,132,133,134,137$, $142,145,146,147,148,226,230,237$, $238,245,246,247,248,261,282,290$

Tromp, Maarten Harpertsz. (Dutch admiral, 1598-1653) 241, 246

Truce Conflicts ('Bestandstwisten', episode in Dutch history, 1609-1621) 152, 166, 229, 248

Twelve-Years' Truce (1609-1621) 30, 138, 151, 152, 162, 199, 273

United Provinces see Dutch Republic

Vaernewijck, Marcus van (Ghent rhetorician and historian, 1518-1569) 29, 274

Veen, Jan van der (Dutch rhetorician and poet, 1578-1659) 209-10

Vélez de Guevara, Luis (Spanish playwright and novellist, 1579-1644) 200 El caballero del sol 200

Villiers, George (Duke of Buckingham, 1592-1628) 183, 185, 197, 203, 204, 284

Virgil or Publius Vergilius Maro (Roman poet, 70-19 BC) 127, 274 Aeneid 127, 274
Visual arts 106

Paintings 12, 16, 27, 106, 199

The Papal Ass 115-16

Vlaminck van Oudshoorn, Cornelis de (ambachtsheer of Oudshoorn) 254, 255,260

Voetius, Gisbertus or Gijsbert Voet

(Dutch theologian, professor of theology and minister, 1589-1676) 257

Vondel, Joost van den (Dutch playwright and poet, 1587-1679) $4,134,222,223,224,228,229,281$, 291

Amsteldamsche Hecuba (1626) 229

Gysbreghtvan Aemstel (1637) 121,135

Maria Stuart (1646) 227, 281

Palamedes (1625) 228

Twee zeevaartgedichten 4

Vorsel, Bonaventura (Flemish minorite) 58

Vorsterman, Willem (Antwerp printer 1504-1543) 46

Vos, Jan (Dutch poet and playwright, 1610-1667) 222, 231, 232, 233, 234, 245, 246, 248, 271

Aran en Titus (1641) 238, 248

'Brittanje aan Euroope' 231

Zee-krygh (1653) 245

Vossius, Gerardus Joannes

(Dutch humanist and theologian, 1577-1649) 103, 158

Vulcanius, Bonaventura or De Smedt (Dutch humanist, 1538-1614) 131

Een warachtighe verclaringhe van een wonderlijck Batement-spel 208, 214

Wael, Job A. van de (Dutch rhetorician) 30

Schiedams Rood Roosjens Spel, van David ende Goliath (1619) 30, 31, 279

War, Frnaco-Spanish 220

Wars, Italian (1494-1495) 38, 39, 48

Wesel, Roemer van (Dutch poet, 1625-after 1693) 248

De lijdende christus, treur-spel (1650) 248, 249

Westerbaen, Jacob (Dutch nobleman, theologian and poet, 1599-1670) 227 
Hollands Vloeck (1653) 246

Klachte van Henriette de

Bourbon 227

Weynsen, Matthias (Antwerp friar, 1480-1547) 65, 66, 74, 85, 86

William I of Orange (German-Dutch nobleman, leader of the Dutch revolt, 1533-1584) 29, 30, 121, 127, 129, $130,132,134,137,144,145,183,224$, $272,273,279,282$

William II of Orange (1626-1650), Stadtholder of Holland, Zeeland, Gelderland and Utrecht (1647-1650) 220, 223, 230-31, 237, 239, 271

William III (1650-1702, Stadtholder in the Low Countries 1672-1702, King of England and Ireland 1689-1702) 252, 255, 256, 258, 262

Winter King see Frederick V

Witt, Cornelis de (Dutch politiian, 1623-1672) 251, 262
Witt, Johan de (1625-1672, Grand Pensionary of Holland 1653-1672) 241, 242, 251, 262, 271

Wright, Abraham (English priest, 1611-1690) 168-69 Delitiae delitiarum (1637)

Wtenbogaert, Johannes (influential Dutch Remonstrant minister, 1557-1644) 155, 156, 163

Zevecotius, Jacobus or Jacques de Zevecote (Dutch priest and playwright, 1596-1642) 125 Belegh van Leyden. Treurspel (1626, 1632) 125

Maria Stuarta / Maria Graeca (1623/1625) 125

Zoet, Jan (Amsterdam poet and polemicist, 1608-1674) 222, 223, 224, 235

Het Toneel der Engelsche elende 235 